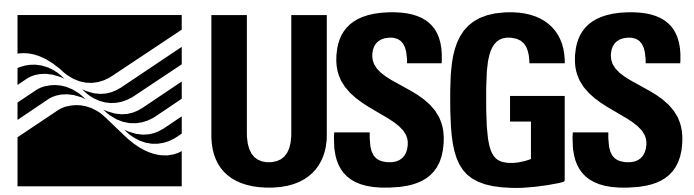

science for a changing world

A Product of the Groundwater Resources Program Prepared in Cooperation with the National Cave and Karst Research Institute

\title{
U.S. Geological Survey Karst Interest Group Proceedings, Carlsbad, New Mexico, April 29 - May 2, 2014
}

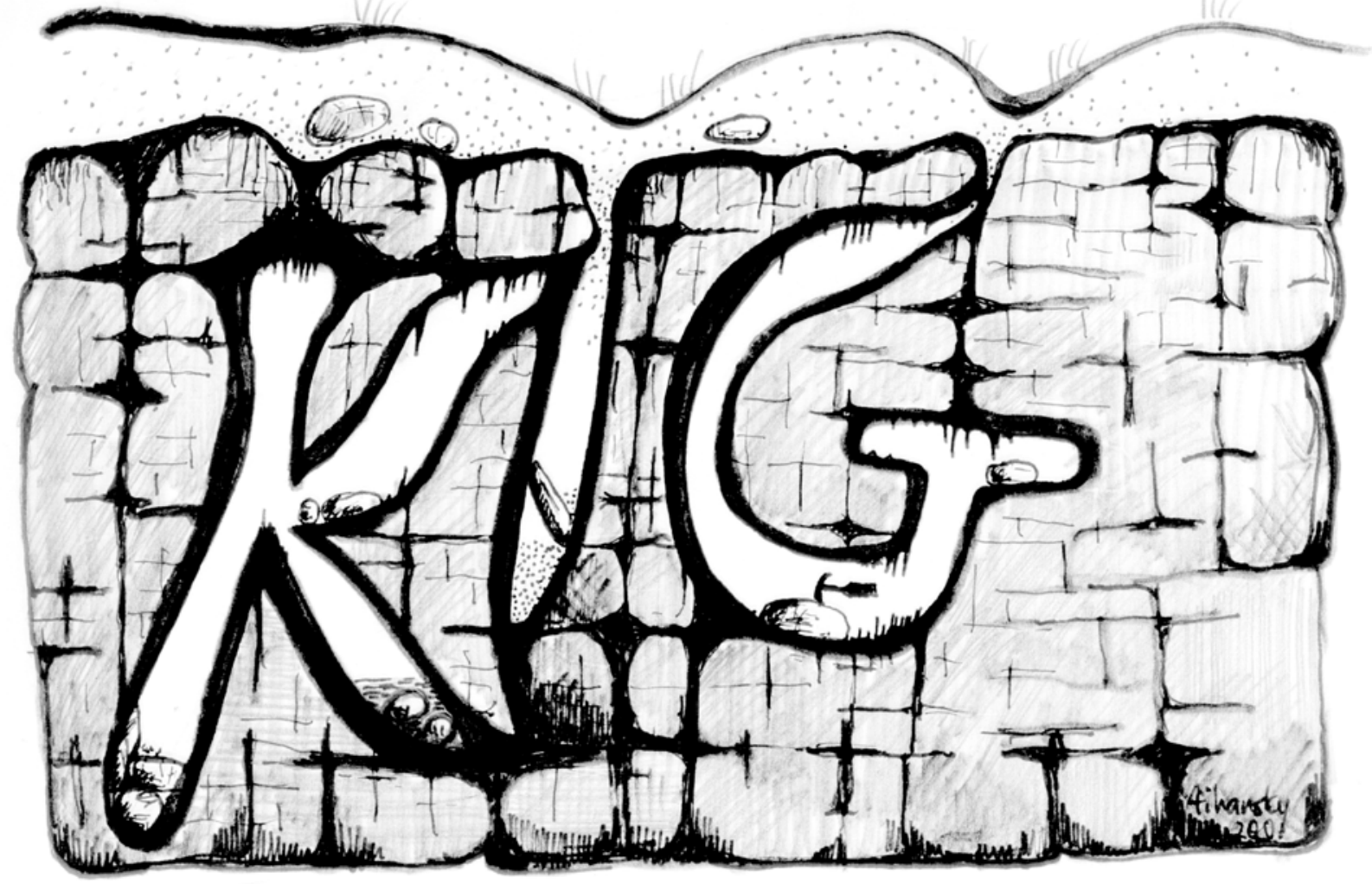

Scientific Investigations Report 2014-5035 



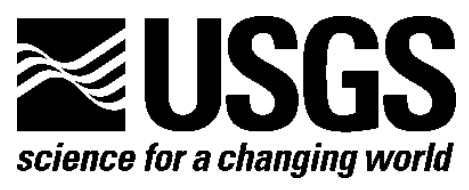

A Product of the Groundwater Resources Program Prepared in Cooperation with the National Cave and Karst Research Institute

\section{U.S. Geological Survey Karst Interest Group Proceedings, Carlsbad, New Mexico, April 29 - May 2, 2014}

Edited by Eve L. Kuniansky and Lawrence E. Spangler

Scientific Investigations Report 2014-5035

U.S. Department of the Interior U.S. Geological Survey 


\section{U.S. Department of the Interior \\ SALLY JEWELL, Secretary}

U.S. Geological Survey

Suzette Kimball, Acting Director

\section{U.S. Geological Survey, Reston, Virginia: 2014}

For product and ordering information:

World Wide Web: http://www.usgs.gov/pubprod

Telephone: 1-888-ASK-USGS

For more information on the USGS-the Federal source for science about the Earth, its natural and living resources, natural hazards, and the environment:

World Wide Web: http://www.usgs.gov

Telephone: 1-888-ASK-USGS

Suggested citation:

Kuniansky, E.L., and Spangler, L.E., 2014, U.S. Geological Survey Karst Interest Group Proceedings, Carlsbad, New Mexico, April 29-May 2, 2014: U.S. Geological Survey Scientific Investigations Report 2014-5035, 155 p., http://dx.doi.org/10.3133/sir20145035.

ISSN 2328-0328 (online)

ISSN 2328-031X (print)

Any use of trade, product, or firm names is for descriptive purposes only and does not imply endorsement by the U.S. Government.

Although this report is in the public domain, permission must be secured from the individual copyright owners to reproduce any copyrighted material contained within this report. 


\section{Contents}

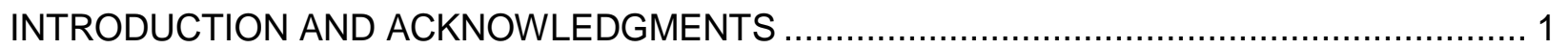

AGENDA U.S. GEOLOGICAL SURVEY KARST INTEREST GROUP WORKSHOP .............. 3

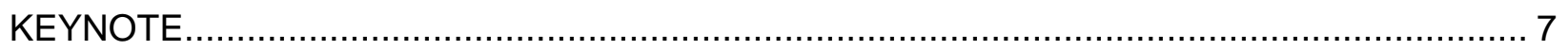

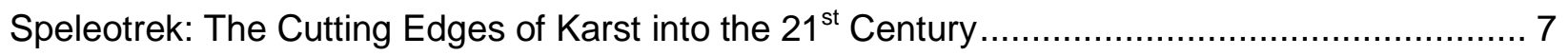

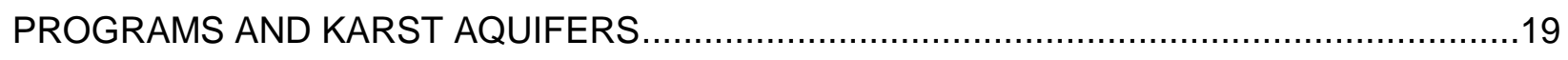

A Preview of "Karst in the United States of America: A Digital Map Compilation and Database"

Groundwater Availability of the Floridan Aquifer System ...............................................28

Assessing Potential Impacts from a Proposed Phosphate Mine on Ashley Spring, a Unique Karst Public Water Supply in the Uinta Mountains, Uintah County, Utah................................30

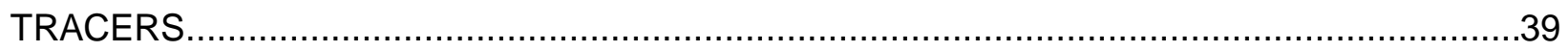

Groundwater Tracing in Arid Karst Aquifers: Concepts and Considerations ............................39

Challenges to a Karst Dye-Tracing Investigation in an Urban Brownfields Area, Springfield,

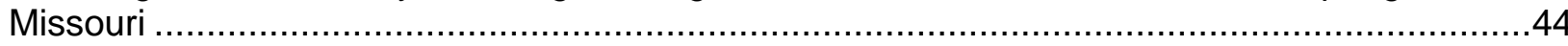

SPELEOGENESIS, GEOLOGIC FRAMEWORK, GEOPHYSICS, AND GEOLOGIC HAZARDS

The Role of Spongework in the Speleogenesis of Hypogenic Caves in the Guadalupe Mountains, New Mexico

Geologic Framework, Structure, and Hydrogeologic Characteristics of the Knippa Gap Area in Eastern Uvalde and Western Medina Counties, Texas

A Hypothesis for Carbonate Island Karst Aquifer Evolution from Analysis of Field Observations in Northern Guam, Mariana Islands.

Using Borehole and Surface Geophysics to Develop a Conceptual Model of Hydrostratigraphic

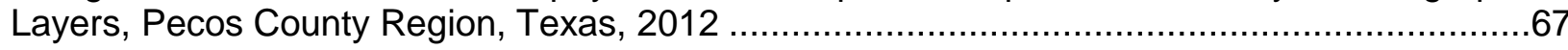

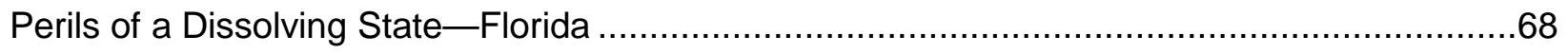

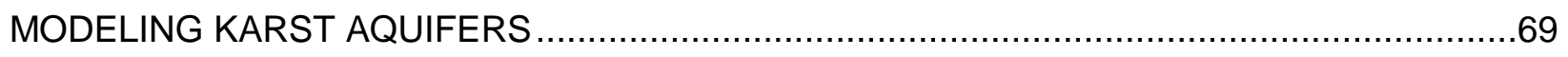

Taking the Mystery Out of Mathematical Model Applications to Karst Aquifers-A Primer .......69

Refined Hydrostratigraphic Framework and Model of the Edwards Aquifer, Texas ..................82

Simulation of Groundwater Flow in the Edwards-Trinity and Related Aquifers in the Pecos County Region, Texas.

Automatic Methods of Groundwater Flow Model Construction of the Ozark Plateaus Aquifer

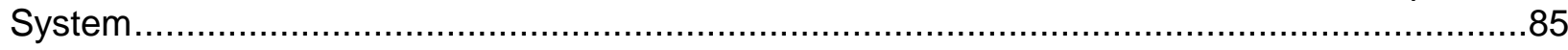

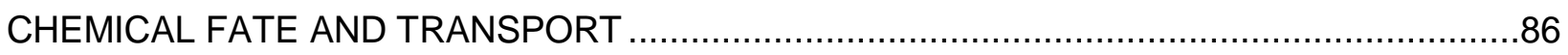

Transport of Salt, Trace Metals, and Organic Chemicals from Parking Lot and Road Surfaces into Mammoth Cave..... 
CAFOs on Karst-Meaningful Data Collection to Adequately Define Environmental Risk, with a Specific Application from the Southern Ozarks of Northern Arkansas

An Initial Investigation of Hydrogeology and Water Quality of Big Creek in the Buffalo River Watershed near a Major Concentrated Animal Feeding Operation.

A Method to Investigate Karst Groundwater Flow in Nash Draw, Eddy County, New Mexico, to Delineate Potential Impacts of Potash Industry Discharge and Runoff . .98

Use of A Dual Continuum Model to Describe Solute Transport in Karst ................................108

GEOCHEMISTRY

Geochemical Evidence for Denitrification in the Epikarst at the Savoy Experimental Watershed, Northwest Arkansas. 109

Geochemistry of Paleokarst Aquifers of the Knox Group in Tennessee and Kentucky ..... 121 Integration of Geochemical and Isotopic Data to Assess Sources of Discharge at a Major Spring in the Edwards Aquifer, South-Central Texas.

Linking Climate Change and Karst Hydrology to Evaluate Species Vulnerability: The Edwards

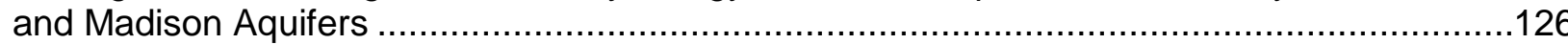

Response of Cave-Stream Bacteria to Sub-Lethal Concentrations of Antibiotics ..................127

Role of Surface Water Dissolved Organic Carbon in the Survival, Growth, and Transport of Escherichia coli in a Deep Limestone Aquifer in South Florida

Cave Bacteria and Crystal Formation in the Laboratory .

Non-Target Bacterial Response to White-Nose Syndrome Treatment: Quaternary Ammonia Compounds and Linear Alkylbenzene Sulfonate

THURSDAY, MAY 1, 2014, FIELD TRIP GUIDE.

Evaporite Karst of the Lower Pecos Valley, New Mexico .135 


\section{INTRODUCTION AND ACKNOWLEDGMENTS}

Karst aquifer systems are present throughout parts of the United States and some of its territories, and have developed in carbonate rocks (primarily limestone and dolomite) that span an interval of time encompassing more than 550 million years. The depositional environments, diagenetic processes, postdepositional tectonic events, and geochemical weathering processes that form karst aquifers are varied and complex, and involve biological, chemical, and physical changes. These factors, combined with the diverse climatic regimes under which karst development in these rocks has taken place, result in the unique dual- or triple-porosity nature of karst aquifers. These complex hydrogeologic systems typically represent challenging and unique conditions to scientists attempting to study groundwater flow and contaminant transport in these terrains.

The dissolution of carbonate rocks and the subsequent development of distinct and beautiful landscapes, caverns, and springs has resulted in the most exceptional karst areas of the United States being designated as national or state parks; commercial caverns and known privately owned caves number in the tens of thousands. Both public and private properties provide access for scientists to study the flow of groundwater in situ. Likewise, the range and complexity of landforms and groundwater flow systems associated with karst terrains are enormous, perhaps more than for any other aquifer type. Karst aquifers and landscapes that form in tropical areas, such as the cockpit karst along the north coast of Puerto Rico, differ greatly from karst landforms in more arid climates, such as the Edwards Plateau in west-central Texas or the Guadalupe Mountains near Carlsbad, New Mexico, where hypogenic processes have played a major role in speleogenesis. Many of these public and private lands also contain unique flora and fauna associated with these karst hydrogeologic systems. As a result, numerous federal, state, and local agencies have a strong interest in the study of karst terrains.

Many of the major springs and aquifers in the United States have developed in carbonate rocks, such as the Floridan aquifer system in Florida and parts of Alabama, Georgia, and South Carolina; the Ozark Plateaus aquifer system in parts of Arkansas, Kansas, Missouri, and Oklahoma; and the Edwards-Trinity aquifer system in west-central Texas. These aquifers, and the springs that discharge from them, serve as major water-supply sources and as unique ecological habitats. Competition for the water resources of karst aquifers is common, and urban development and the lack of attenuation of contaminants in karst areas can impact the ecosystem and water quality of these aquifers.

The concept for developing a platform for interaction among scientists within the U.S. Geological Survey (USGS) working on karst-related studies evolved from the November 1999 National GroundWater Meeting of the USGS. As a result, the Karst Interest Group (KIG) was formed in 2000. The KIG is a loose-knit, grass-roots organization of USGS and non-USGS scientists and researchers devoted to fostering better communication among scientists working on, or interested in, karst science. The primary mission of the KIG is to encourage and support interdisciplinary collaboration and technology transfer among scientists working in karst areas. Additionally, the KIG encourages collaborative studies between the different mission areas of the USGS as well as other federal and state agencies, and with researchers from academia and institutes. The KIG also encourages younger scientists by participation of students in the poster and oral sessions.

To accomplish its mission, the KIG has organized a series of workshops that are held near nationally important karst areas. To date (2014) six KIG workshops, including the workshop documented in this report, have been held. The workshops typically include oral and poster sessions on selected karst-related topics and research, as well as field trips to local karst features. Proceedings of the workshops are published by the USGS and are available online at http://water.usgs.gov/ogw/karst/kig. 
The first KIG workshop was held in St. Petersburg, Florida, February 13-16, 2001, in the vicinity of the large springs and other karst features of the Floridan aquifer system. The second KIG workshop was held August 20-22, 2002, in Shepherdstown, West Virginia, in proximity to the carbonate aquifers of the northern Shenandoah Valley and highlighted an invited presentation on karst literature by the late Barry F. Beck of P.E. LaMoreaux and Associates. The third KIG workshop was held September 12-15, 2005, in Rapid City, South Dakota, nearby to karst features in evaporites and limestones of the Madison Group in the Black Hills of South Dakota, including Wind Cave National Park and Jewel Cave National Monument. The workshop also included a featured presentation by Thomas Casadevall, Central Region Director, USGS, on the status of earth science at the USGS and evening trips to Jewel Cave led by Mike Wiles, National Park Service (NPS) and Wind Cave led by Rod Horrocks, NPS. The fourth KIG workshop was held May 27-29, 2008, and hosted by the Hoffman Environmental Research Institute and Center for Cave and Karst Studies at Western Kentucky University in Bowling Green, Kentucky, near Mammoth Cave National Park and karst features of the Chester Upland and Pennyroyal Plateau. The workshop featured a late-night field trip into Mammoth Cave with Rickard Toomey and Rick Olsen, NPS. The fifth workshop was held April 26-29, 2011, and was a joint meeting of the USGS KIG and University of Arkansas HydroDays, hosted by the Department of Geosciences at the University of Arkansas in Fayetteville. The workshop featured an outstanding field trip to the unique karst terrain along the Buffalo National River of the southern Ozarks and a keynote presentation on paleokarst in the United States by Art and Peggy Palmer.

This sixth and current 2014 KIG workshop is hosted by the National Cave and Karst Research Institute (NCKRI) in Carlsbad, New Mexico, with Director of NCKRI, George Veni, serving as co-chair of the workshop with Eve Kuniansky, USGS. The session planning committee for this sixth workshop includes Van Brahana, USGS retired and University of Arkansas Professor Emeritus; Tom Byl, USGS and Tennessee State University; Zelda Bailey, former Director of NCKRI and retired Director, National Institute of Standards and Technology, Boulder Laboratory, Colorado; Patrick Tucci, USGS retired; and Mike Bradley, Allan Clark, Geoff Delin, Daniel Doctor, James Kaufmann, Eve Kuniansky, Randy Orndorff, Larry Spangler, and Dave Weary of the USGS. The karst hydrology field trip on Thursday will be led by Lewis Land (NCKRI karst hydrologist) and the optional Friday field trip on the geology of Carlsbad Caverns National Park will be led by George Veni. The keynote speaker is Dr. Penelope Boston, Director of Cave and Karst Studies at New Mexico Tech, Socorro, and Academic Director at NCKRI, who will address the future of karst research. Additionally, there is a featured presentation "Irish karst and its management," by Caoimhe Hickey, The Geological Survey of Ireland, preceding a panel discussion on "Collaboration During Times of Limited Resources."

The extended abstracts of USGS authors were peer reviewed and approved for publication by the U.S. Geological Survey. Articles submitted by university researchers and other federal and state agencies did not go through the formal USGS peer review and approval process, and therefore may not adhere to our editorial standards or stratigraphic nomenclature and is not research conducted or data collected by the USGS. However, all articles had at a minimum of two peer reviews, and all articles were edited for consistency of appearance in the published Proceedings. The use of trade, firm or product names in any article is for descriptive purposes only and does not imply endorsement by the U.S. Government. The USGS, Office of Groundwater, provides technical support for the Karst Interest Group website and public availability of the Proceedings from these workshops, and the USGS Groundwater Resources Program funds the publication costs. Finally, the cover illustration is the work of Ann Tihansky, USGS, used since the first KIG workshop in 2000.

Eve L. Kuniansky

USGS Karst Interest Group Coordinator 
AGENDA U.S. GEOLOGICAL SURVEY KARST INTEREST GROUP WORKSHOP

April 29-May 2, 2014 Carlsbad, New Mexico

Hosted by the National Cave and Karst Research Institute

TUESDAY, APRIL 29

Registration

Start at 8:00 am-- All day - pick up name tags and Proceedings

Welcome and Introductions

8:20 - 8:40 Eve Kuniansky, U.S. Geological Survey, Karst Interest Group Coordinator and

George Veni, Director of National Cave and Karst Research Institute

\section{Programs and Karst Aquifers (Randall Orndorff, moderator)}

8:40 - 9:00 A preview of "Karst in the United States of America: A digital map compilation and database" by David Weary and Dan Doctor

9:00 - 9:20 Groundwater availability of the Floridan aquifer system by Andrew O’Reilly and Eve Kuniansky (presenter)

9:20 - 9:40 An overview of the Ashley Spring groundwater system - a unique public watersupply karst spring in northeastern Utah, and potential impacts from a proposed phosphate mine by Lawrence Spangler

9:40 - 10:20 BREAK

KEYNOTE (Zelda Chapman Bailey, moderator)

10:20 - 10:40 Speleotrek: Cutting edge karst into the 21st century by Penelope Boston, Director of Cave and Karst Studies, New Mexico Tech and Academic Director, National Cave and Karst Research Institute

Tracers (Zelda Chapman Bailey, moderator)

10:40 - 11:00 Groundwater tracing in arid karst aquifers: Concepts and considerations by George Veni

11:00 - 11:20 Challenges to a karst dye-tracing investigation in an urban Brownfields area by Douglas Gouzie, Kevin Mickus, and Micah Mayle

\section{1:20 - 1:20 LUNCH ON YOUR OWN}

\section{Modeling Karst Aquifers (J. Van Brahana, moderator)}

$1: 20-1: 40$

$1: 40-2: 00$

$2: 00-2: 20$

$2: 20-3: 00$
Taking the mystery out of mathematical model applications to karst aquifers-A primer by Eve Kuniansky

Refined hydrostratigraphic framework and model of the Edwards aquifer, Texas by Beth Fratesi, Ron Green, Ronald McGinnis, Hakan Basagaoglu, Leslie Gergen, Jim Winterle, Marques Miller, and Paul Bertetti

Simulation of groundwater flow in the Edwards-Trinity aquifer in the Pecos County region, Texas by Brian Clark, Jonathan Bumgarner, and Natalie Houston

BREAK 


\section{Chemical Fate and Transport (Michael Bradley, moderator)}

$3: 00-3: 20$

Transport of salt, trace metals, and organic chemicals from parking lot and road surfaces into Mammoth Cave by David Solomon, Irucka Embry, Bobby Carson, Roger Painter, Lonnie Sharpe, Rick Toomey, and Tom Byl (presenter)

$3: 20-3: 40$

$3: 40-4: 00$

CAFOs on karst-Meaningful data collection to adequately define environmental risk, with a specific application from the southern Ozarks of northern Arkansas by Van Brahana, Joe Nix, Carol Bitting, Chuck Bitting, Ray Quick, John Murdoch, Amie West, Sarah Robertson, Grant Scarsdale, and Vanya North

A method to investigate karst groundwater flow in Nash Draw, Eddy County, New Mexico, to delineate potential impacts of potash industry discharge and runoff by Jim Goodbar and Andrea Goodbar

$4: 00-6: 00$

Poster Session at National Cave and Karst Research Institute

WEDNESDAY, APRIL 30

Geochemistry, Fate and Transport, Microbial Ecology and Karst Ecosystems (Patrick Tucci, moderator)

$8: 20-8: 40$

Geochemical evidence for denitrification in the epikarst at the Savoy Experimental Watershed, northwest Arkansas by Jozef Laincz and Phillip D. Hays

8:40 - 9:00 Geochemistry in paleokarst aquifers of the Knox Group in Tennessee and Kentucky by Michael Bradley and Marty Parris

9:00 - 9:20 Linking climate change and karst hydrology to evaluate species vulnerability: The Edwards and Madison aquifers by Barbara Mahler, Andrew Long, John Stamm, Mary Poteet, and Amy Symstad

9:20 - 9:40 Response of cave-stream bacteria to sub-lethal concentrations of antibiotics by Tom Byl, Petra Byl, and Rickard Toomey

9:40 - 10:20

BREAK

\section{Modeling Karst Aquifers (David Weary, moderator)}

10:20 - 10:40 Automatic methods of groundwater flow model construction of the Ozark Plateaus aquifer system by Brian Clark and Joseph Richards

10:40 - 11:00 A hypothesis for carbonate island karst aquifer evolution from analysis of field observations in northern Guam, Mariana Islands by John Jenson, Danko Taboroŝi, Kolja Rotzoll, John Mylroie, and Stephen Gingerich (presenter)

\section{Speleogenesis (David Weary, moderator)}

11:00 - 11:20 The role of spongework in the speleogenesis of hypogenic caves in the Guadalupe Mountains, New Mexico by Mark Joop

\section{1:20 - 1:20 LUNCH ON YOUR OWN}

\section{Featured Presentation}

$1: 20-1: 40$

Irish karst and its management by Caoimhe Hickey, The Geological Survey of Ireland 
PANEL DISCUSSION: Collaboration During Times of Limited Resources (Eve Kuniansky, moderator)

$1: 40-3: 00$

\section{U.S. Department of the Interior panelists:}

James Goodbar, Bureau of Land Management,

Randy Orndorff, U.S. Geological Survey, and

Dale Pate, National Park Service

University Perspective:

Doug Gouzie, Missouri State University

Institute Perspective:

George Veni, National Cave and Karst Research Institute

Other Federal Agency with Stewardship Responsibilities:

Johanna Kovarik, U.S. Department of Agriculture-Forest Service

3:00-3:40 BREAK

Karst Interest Group Business

$3: 40-4: 00$

Discuss proposals for location of next KIG workshop in 2017

4:00-4:20

Thursday Field Trip overview and logistics by Lewis Land

THURSDAY, MAY 1

$7: 45 \mathrm{AM}-5: 30 \mathrm{PM}$

Field Trip Day 1—Evaporite karst of the Lower Pecos Valley, New Mexico by Lewis Land

FRIDAY, MAY 2

$7: 45 \mathrm{AM}-5: 30 \mathrm{PM}$

Field Trip Day 2-Geology tour of Carlsbad Cavern by George Veni

\section{POSTERS}

\section{Geologic Framework, Geophysics, and Geologic Hazards}

Geologic framework, structure, and hydrogeologic characteristics of the Knippa Gap area in eastern Uvalde and western Medina Counties, Texas by Allan K. Clark (presenter), Diana E. Pedraza, and Robert R. Morris

Three-dimensional model of the hydrostratigraphy and structure in and around the Camp Stanley storage facility, northern Bexar County, Texas by Michael P. Pantea and Allan K. Clark (presenter)

Using borehole and surface geophysics to develop a conceptual model of hydrostratigraphic layers, Pecos County region, Texas, 2012 by Jonathan V. Thomas, Johnathan R. Bumgarner, Gregory P. Stanton, Andrew P. Teeple, and Jason D. Payne

Perils of a dissolving State-Florida by Clint Kromhout

\section{Geochemistry, Fate and Transport, Microbial Ecology, and Karst Ecosystems}

Role of surface-water dissolved organic carbon in the survival, growth, and transport of Escherichia coli in a deep limestone aquifer in south Florida by Ronald W. Harvey, Jen Underwood, John Lisle, David W. Metge, and George Aiken

Integration of geochemical and isotopic data to assess sources of discharge at a major spring in the Edwards aquifer, south-central Texas by MaryLynn Musgrove and Cassi L. Crow

Cave bacteria and crystal formation in the laboratory by Petra Byl, Aaron Covey, Jessica Oster, Tasneem Siddiquee, and Tom Byl (presenter) 
Non-target bacterial response to white-nose syndrome treatment: Quaternary ammonia and linear alkyl sulfonate compounds by JeTara Brown, Zheer Ahmed, and Tom Byl (presenter)

Flowable fill for subsurface cavity remediation by Chase Kicker (Carlsbad High School, accepted at New Mexico Tech for fall, 2014)

\section{Chemical Transport and Contamination in Karst}

Use of a dual continuum model to describe solute transport in karst by Justin Harris, Roger Painter, Lonnie Sharpe and Tom Byl (presenter)

An initial investigation of hydrogeology and water quality of Big Creek in the Buffalo River watershed near a major concentrated animal feeding operation By Victor L. Roland II, Phillip Hays, Van Brahana, and Erik Pollock

\section{Demonstration}

The National Karst Map by David Weary 


\title{
KEYNOTE
}

\section{Speleotrek: The Cutting Edges of Karst into the $21^{\text {st }}$ Century}

\author{
By Penelope J. Boston ${ }^{1,2}$ \\ ${ }^{1}$ New Mexico Tech, 801 Leroy Place, Socorro, NM 87801 \\ ${ }^{2}$ National Cave and Karst Research Institute (NCKRI), 1400-1 Cascades Ave., Carlsbad, NM 88222
}

\begin{abstract}
Exploration and study of Earth's subsurface has been the delight of some but a blank slate to many within the mainstream geoscience and biology communities until perhaps the past several decades. Especially in the United States, many aspects of cave and karst studies have been marginalized but this picture is now changing. Increasing awareness of karstic processes include the classic areas of cave origins and development (speleogenesis) and karst geohydrology, but now include such fields as geomicrobiological influences on karst, the role of karst and cave environments in biogeochemical cycling, and caves as repositories of several types of important climate proxy data. A dawning appreciation of the subsurface habitat connection with surface habitats is upon us, especially with regard to material and energy transfers. Even apparent examples of karstic phenomena beyond Earth have begun to seep into the larger scientific landscape. Such contemplation can provide a new basis for comparative studies enabling us to test our ideas in more than one planetary context. Finally, new technology and methodologies emerging now will help to advance karstic studies into the future and bring karst science into the mainstream of the $21^{\text {st }}$ century science portfolio. Implications of karst in matters of human welfare, and opportunities for applications of new arenas of research are numerous. Concerns range from geohazards associated with karst and special issues unique to karst aquifer management, to the potential for unique compounds of pharmaceutical and industrial uses derived from subsurface sources. The $21^{\text {st }}$ century is shaping up to be a productive time for karst understanding and utilization.
\end{abstract}

\section{KARST IN THE BROAD CONTEXT}

The existing body of work on karst and related topics is an important source of understanding of fundamental processes, not only in relation to the particulars of dissolvable landforms, but also in the greater context of the Earth sciences writ broadly. Shallow crustal and surficial processes involving aqueous dissolution, consequences for hydrological drainage, modification of the landforms overlying and underlying soluble rock facies, and the properties of caves as environments for microbial and macroscopic biota are already acknowledged arenas of speleology. In a highly interdisciplinary 2007 workshop organized by the Karst Waters Institute (KWI), a number of major research directions for the future of karst were identified (Martin and White, 2008).

However, since that assessment was completed there are a handful of developments of particular note that are newly emerging or are undergoing major development and these constitute the topic of this paper. By its very nature, speleology is a place-based, highly interdisciplinary field. Where karst geohydrology overlaps with speleology, research also benefits from interdisciplinary synthesis. Some cutting edge research fits within the geoscience framework and some is clearly biological in nature. Often these broad disciplines overlap, and all research approaches will be enhanced by new technologies that can allow us to better detect, access, and study caves and the karstic terrains that house them. Furthermore, any ways in which karst studies can fruitfully interact with other scientific research areas will enhance both the broader picture and in turn feed back into further invigorating karst science itself.

\section{CUTTING-EDGE SCIENCE DIRECTIONS}

Although numerous questions remain to be answered and understood in detail, many aspects of classical karst science are relatively mature fields, with suites of major fundamental principles currently understood and implementable in field, laboratory, and modeling efforts (Palmer 2007; Ford and Williams, 2007). However, several aspects of karst studies that have been little explored are now gaining attention and are discussed below. 


\section{More Than Just $\mathrm{CaCO}_{3}$ !}

The classic conception of karst dates from as far back as the mid-17th century (Larsen, 2003) and was described originally for the Dinaric carbonate karst of Slovenia and surrounding areas. Jovan Cvijić, the famous Serbian scientist and polymath of the late 19th century, also made seminal contributions to the early concepts of carbonate karst, publishing a major work on the subject in 1895. This early work firmly planted the notion of karst in carbonate lithology.

Arguments have raged in the past over whether the term karst should be reserved only for terrains in calcium carbonate rock types (see Monroe (1970) for a typical version of such a definition of karst.) Perhaps most modern thinkers on the subject have broadened the scope of karst to encompass any geomorphic terrain type that relies on dissolution of soluble rock as its primary driving mechanism (e.g. Ford, 1980). Surface and subsurface characteristics typically associated with many karst terrains can be helpfully diagnostic in assessing the karst status of a particular area but should not be required as definitive because of the great complexity of features that can be considered as karst. The trend to broaden the lithologies under the karst umbrella is very handy because there are a number of compelling examples in a variety of rock types around the world!

Gypsum and other evaporite minerals are an important additional type of dissolvable rock with wide global distribution of resulting landforms and caves. Many speleologists already refer to these lithologies as karst (see Klimchouk and others (1996) for a review of the state of the art at that time.) Powerful comparisons of gypsum karst with carbonate karst can yield a refined partitioning of the relative roles of physical and chemical processes that govern solubility of bedrock in the natural environment. For example, the major influence of $\mathrm{pH}$ that we see in carbonate karst is irrelevant to gypsum dissolution, and of course, the intrinsically high solubility of calcium sulfate is itself a critical factor in the origin and development of gypsum karst. Truly enormous and spectacular examples of gypsum caves and karstification exist in western Ukraine and Moldova (e.g. Andrejchuk, 1996; Klimchouk and Andrejchuk, 2002). Smaller scale but scientifically important examples occur in many other parts of the world.

Also associated with many evaporite rocks are halite $(\mathrm{NaCl})$ deposits. Such salt deposits may house caves and related karst drainage features. Seminal work by a relatively small number of investigators (e.g. Frumkin, 1994; Bosak and others, 1999) has enabled understanding of the basic behaviors of such systems but much remains to be done to extend understanding. Halite karst is uncommon but widely distributed, occurring in Iran, Israel, Algeria, Chile, Romania, Spain, Syria, Tadjikistan, and Tunisia (Chabert and Courbon, 1997).

Even more exotic karstic processes occur in quartzite, most notably in massifs in South America (Gibbs and Barron, 1993; Piccini, 1995). Wray (1997) has argued convincingly that caves in South American quartzite massifs qualify as true dissolutional karst. Further, he points to a number of other quartzite karst occurrences in Chad and Australia. Quartzite karst is one instance among a growing number of cases that implicates biological processes in the alteration, modification, or even inception of a karstic phenomenon. In this case, microbiologically enhanced silica dissolution and mobilization appears to be significant in the development of karst in siliceous materials like quartzite (e.g. Chalcraft and Pye, 1984; Zhou and others, 2011).

Further comparative study of soluble rock processes can be extremely fruitful, allowing us to explore along a gradient from extremely soluble and needing only the presence of water (halite and gypsum), to the classical $\mathrm{pH}$ dependent karst in limestone, dolomite, and marble, to extremely refractory siliceous rock like quartzite that requires the presence of significant microbial (and perhaps plant) chemical mobilization.

\section{Caves as Key Interface Systems in the Critical Zone}

The Critical Zone (CZ), that part of the Earth that houses the interactions of the atmosphere, hydrosphere, biosphere, and near surface lithosphere, was invented as a defined phrase over a decade ago in a largely ecological context (National Research Council, 2001). The 
intent was to capture the essence of the thin outer envelope of our planet within which all life resides, and where we conduct the vast majority of our human activities. Caves are discrete systems uniquely positioned to capture these dynamic interactions that collectively describe the Critical Zone. Indeed, caves may represent the single best example of the terrestrial Critical Zone in miniature since they contain some combination of atmosphere, fluid, rock, often sediment, a huge array of microorganisms, and often macroscopic animal life.

There are several key properties of caves that come together to enable us to take a systems approach to cave study and place it within the Critical Zone context: 1) all three common phases of matter come together in caves, 2) caves are separated from the surface by significant boundary conditions, and 3) they are partly open systems vis a vis energy and materials, but over short timescales they can act as discrete closed systems!

Ideally, subsurface cavities as Critical Zone examples can capture the attention of non-karst scientists as well as speleologists to further the understanding of interfaces between the various compartments of the Earth system both in caves and as applicable to the wider surface environment. A recent major assessment of Critical Zone science and applications in response to various global environmental challenges set forth a broad plan for research and applications and did mention karst in connection with hydrogeology. However, the paper did not mention caves a single time in the course of a rather lengthy document, in spite of the unique nature of karst habitats (Banwart and others, 2013). More work on the part of the karst community is necessary to sensitize the broad scientific community to the importance of karst systems on Earth and their properties specifically in the Critical Zone context.

\section{Caves in the Era of Geomicrobiology}

A major new research thrust over the past 20 years or so has been subsurface geomicrobiology studied at depths ranging from shallow caves and lava tubes to extremely deep mines and deep within the ocean floors. While there is still much to be learned about the unusual and often unique species of subterranean animals that inhabit caves and cavities within limestone aquifers and other types of caves, it is in the realm of microbiology that many new research directions are particularly coming to the fore.

The awareness of microbial interactions with rocks and minerals has developed from the surface down, with an important early attempt to classify organisms on the basis of how they were positioned within, over, or under rocks (Golubic and others, 1981). Since that seminal attempt, our grasp of the degree to which Earth's terrestrial and marine crust is thoroughly infested with tiny life forms has greatly expanded. We now know that there is a vast global subsurface rock fracture habitat that houses countless strains of microorganisms, and that aquifers, caves, and even volcanic terrains, and the immense ocean floor with a mix of young and very aged rocks are part of the rock fracture wilderness (Boston and others, 2001, 2009a; Cowan and others, 2003; Frederickson and Balkwill, 2006; Gihring, 2006; Lin and others, 2006; Northup and Lavoie, 2001). Clearly caves and karst systems are vital and important parts of this hidden microbial wilderness because they can provide us windows into that terra incognita.

In our research team's experience in caves, we see unique features of subsurface microbial communities that often include extremely high biodiversity and a large degree of habitat partitioning at a very fine spatial scale on the order of centimeters to meters (Boston and others, 2009b). In contrast, those working in the deep subsurface may be seeing a much reduced biodiversity, perhaps even as little as a single species (Chivian and others, 2008)! The pace of growth can be very slow in the typically energylimited subsurface (Kieft and Phelps, 1997; Boston and others, 2009b) and opportunities for transport around such systems can be severely limited by lithologic and hydrologic barriers.

Coupled with the growing understanding of the vertical extent of the rock fracture habitat, the awareness of the role of organisms in precipitation of minerals has been occurring at the same time (e.g. Banfield and Nealson, 1997; Newman and Banfield, 2002). This has been a critical development in interpreting how many subterranean microbes make their living 
chemolithotrophically, that is, by transforming inorganic materials like minerals into energy rather than relying for energy on utilization of organic compounds derived from the aboveground biosphere. Oxidation of metal-containing minerals is a very common energy-acquisition mechanism, and the proximity to the waste products of those transformations make subterranean microbes inclined to auto-fossilize as they are growing, thus providing a mechanism for exquisite preservation of biotextures and even microbial body fossils (e.g. Boston and others, 2001, 2009b; Curry and others, 2009; Melim and others, 2001, 2009). Additionally, the ubiquity of biofilms that the organisms make for protection and manipulation of the chemistry of their environments, also contributes to the production and preservation of distinctive biosignatures including biomineral textures. Battin and colleagues (2007) have exhorted us to view biofilms as miniature landscapes and those who study these materials are well-acquainted with the clear parallels to the larger scale landscapes we see in nature.

Very small cell sizes (100-500 nm diameter) and very slow growth rates are common in subsurface microbial communities and presumably are an adaptation to stringently limited energy sources to be found there (Kieft, 2000, 2002). Energy limitation is also coupled with the absence of grazing by animals or protists in many of the deeper systems that allows organisms to prosper without having to "outgrow" the rate at which they are being consumed by other organisms (Boston and others, 2009b).

A further outgrowth of the work of a number of investigators is beginning to point to the role of microorganisms in low temperature hydrothermal ores (e.g. Southam and Saunders, 2005), and particularly copper (Enders and others, 2006), and gold (Karthikeyan and Beveridge, 2002; Lengke and Southam, 2006; Southam and others, 2009). Carbonate systems that host emplacement of such ores as a result of a granitic intrusion are known as skarn deposits (Einaudi and Burt, 1982). The potential for use of organisms from these environments is great and could be used for biomining, bioremediation, and biobeneficiation (Shannon and Unterman, 1993; Rawlings and others, 2007).

Importantly for purposes of human use, many subsurface microbes produce a wealth of unusual chemical compounds of potential use to the pharmaceutical, industrial, and remediation communities, thus providing a major new application for speleology (Poulson and others, 1986). Much of the work that has been done on these compounds has not yet been published in the open literature for a variety of reasons, one of which is the uncertain legal framework under which potentially commercially important compounds coming from organisms within the purview of a national land management agency should be handled (e.g. Northup and others, Boston and others, and Mallory and others, unpublished data).

Besides the microorganisms that we can understand well enough to at least study, an extraordinary biological morphology has come to our research group's attention that we are still at a loss to explain after 15 years of finding variants of this morphology in a variety of caves around the world in all lithologies (Melim and others, 2008; Northup, Boston, and Spilde, unpublished data). Very tiny hexagonal mesh tubes, $\sim 0.5 \mu \mathrm{m}$ in diameter and up to several tens of $\mu \mathrm{m}$ in length appear draped across the micro-landscape in scanning electron micrographs. They display a host of mineralogical characteristics indicating that they are covered by compounds in their environment. We do not know who or what these structures are; we have so far not succeeded in growing them, and the long dance cards of DNA strains that we obtain cannot be matched up to a single morphology seen only in electron micrographs. Are they some sort of cellular skeletons? Are they microstructures belonging to a higher life form? Are they organisms in their own right? So far we are stumped.

However tantalizing it is to study the peculiar and exotic as with our reticulated filaments described above, Northup and Lavoie (2001) have pointed out that, "Caves should be used as experimental study systems for geomicrobiology, not because they are strange, but because they are simple and often locally abundant, allowing for replicate studies...." 
This is an important observation which means that we do not necessarily need to seek out the most extreme and extraordinary caves or bizarre-appearing life forms in order to study the geomicrobiology. All caves can offer important insights into bio-diversity, functional diversity, critical metabolic pathways, and metabolic products that may be of use for human concerns.

\section{Subsurface Biodiversity as a Hydrological Proxy}

Patterns of microbial and functional gene biodiversity are on the threshold of emerging from phylogenetic studies of well samples, borehole cuttings, natural caves, active and abandoned mines, deep ocean drilling cores, and from beneath glaciers and ice fields. As the databases swell with entries at an ever greater pace due to continuous improvements in the technology and lower analytical cost per sample, it is now possible to suggest that the emerging patterns may provide useful proxies for hydrological connectivity in fractured aquifers that are difficult to measure directly. I have expressed this as karst-controlled biogeography of subsurface life (Boston, 2002). The essence of the idea is that organisms move very slowly through a connected fracture system in the subsurface. Transport mechanisms include fluid flow, which can be extremely slow, and active motion by organisms with independent motility, also typically slow. The patterns of propagation of organisms through the subsurface and their relationships to one another will eventually be able to provide insights into connectivity in subsurface systems that may be difficult to infer by direct physical evidence.

Besides the inherently slow nature of the two transport mechanisms mentioned above, there are a number of other roadblocks to microbial movement through a karst system, ranging from geological barriers like impermeable facies, to microbiologicallyinduced blockage of porosity and permeability by biofilms and biominerals that the organisms may produce. The biofilm lifestyle is ubiquitous in nature and its antiquity dates to some of the earliest evidences of life on Earth, some 3.25 billion years ago (Hall-Stoodley and others, 2004). Thus, organisms may well have been influencing porosity and permeability of rock masses in the crust for the vast majority of
Earth's geological history and are still doing that today.

\section{Climate Proxies in Caves}

Several decades ago, calcite in caves was identified as important material for investigating climate records, particularly during non-glacial times (e.g. Gascoyne, 1992; Bar-Matthews and others, 1996). Of the many potential data types that calcite speleothems may supply, stable isotope ratios have gained ascendency and are being used extensively to reconstruct ancient climates (Ghosh and Brand, 2003). As those authors point out in the paleoclimate context, "Atmospheric CO2 provides a link between biological, physical and anthropogenic processes in ecosystems.” As we well know, $\mathrm{CO} 2$ is an intrinsic part of karst mechanisms and thus, the use of speleothem stable isotopes as one of the climate proxy data sets has become very popular (Fairchild, 2006). In concert with stable isotopic fractionation, recent work (Woodhead and others, 2010) has extended the radiometric dating timeline back to ancient speleothems in paleokarst systems as far back as the Permian, which makes such studies even more useful. Speleothem climate study using stable isotopes is thus, a tremendously exciting and promising field of research. However, what has not yet been addressed is the potential for microbial interference in these signals. Microorganisms are not known to alter the fractionation of oxygen, so the O16/O18 ratio used to indicate evaporation and indirectly temperature is probably safe from microbial effects. However, carbon is highly fractionated between C13 and C12 isotopes on the basis of photoautotrophy or chemolithotrophy, both of which slightly favor the lighter isotope and can be used to define carbon sources and sinks (see Ghosh and Brand, 2003, for a nice explanation of these complicated interactions.) Organic carbon received from above-ground, coupled with chemolithotrophic carbon fixation by microorganisms in-cave, complicated further by reports of direct excavation of solid carbonate by microorganisms (Garcia-Pichel and others, 2010), means that the straightforward interpretation of carbon in the climate context is not always possible and certainly presents caveats to be considered. 
Caves and rock shelters have been identified as excellent sediment traps in the archaeological context (Colcutt, 1979) and this also applies to their role as sediment traps in general. Further, vegetation indicators in sediments are often well preserved in caves. Primarily, pollen has been studied in this context although not exploited as much as it can be (McGarry and Caseldine, 2004) but plant biominerals (known as phytoliths) and diatoms (photosynthetic algae with silica tests) are equally promising and often the most abundant botanical remains recovered from cave sites. For several good examples of combining these data types see Martínez and others (2013) and Trombold and IsradeAlcantara (2005). The use of phytoliths in climate reconstruction has now been applied to very recent climate and vegetation change of only several hundred years in the past (Morris and others, 2009).

The partitioning of trace elements in speleothems as indicators of ancient conditions has also been explored, although to a far lesser degree than the other proxy data sets. This includes laboratory simulations of uptake of trace elements as well as field observations of natural systems (Huang and others, 2001a, b; Treble and others, 2005; Johnson and others, 2006, Day and Henderson, 2004). There is additional potential for applying this approach to cave climate records.

Broadly viewed, all of the proxy indicators of climate discussed above can be combined fruitfully in cave studies (Couchard, 2008). For an excellent example of vegetation bioindicators combined with isotopic data, see Scott (2002). In the future, studies which attempt to crosscorrelate all possible climate data sets contained within caves could be immensely valuable in helping us to unravel Earth's past climates in non-marine and low- to mid-latitude environments.

\section{Extraterrestrial Karst?}

The tantalizing prospect of extraterrestrial caves ranges from lava tubes, pit crater shafts, and other collapse features first speculated about and then observed on the Moon (Oberbeck and others, 1969; Greeley, 1971; Sakimoto and others, 1997; Haruyama and others, 2009), and Mars (Wyrick and others, 2004; Cushing and others, 2007; Cushing, 2012) to hypothetical exotic true karst in radically different planetary settings (Boston, 2004; Grin and others, 1998, 1999). Within this context, we include water ice "bedrock", liquid methane rain, and derived organic surface "soil” on Titan (Mitchell and Malaska, 2011; Malaska and others, 2011). The epistemological power of comparative planetary studies can now be extended into speleology. Can we take what we believe we understand about karstic processes on Earth and validly translate that to another planetary body and vice versa? Such a rigorous test bed could play an important role in providing new perspectives and potentially new insights.

In order to handle the concept of karstic phenomena on other planetary bodies, a new conceptual framework is needed. A number of speleologists have devised schemes for karst or cave classification that are of great utility for Earth applications (e.g. Cams, 1989; Dreybrodt, 1988; Ford and Williams, 1989; Self and Mullan, 1996). However, most may not fit some of the more unusual processes that we can anticipate seeing on other bodies. Table 1 shows an ongoing attempt to reduce the complexity of karst and cave processes that may be seen on other planets to basic physical and chemical processes (modified from Boston, 2004). As a work in progress, this is hardly definitive but a start in attempting to rethink the issues involved in radically different gravitational environments.

\section{CUTTING-EDGE TECHNOLOGIES}

New non-invasive or less invasive methodologies can reveal the subsurface in new ways or allow us to directly explore them using robotic proxies. Application of well known techniques to the cave environment is one important direction and exemplified by the development of a prototype mass spectrometer for in-situ analysis of cave atmospheres working toward a better understanding of the gases that make up cave air (Patrick and others, 2012). Other well known instruments could also be tailored for the rigorous challenges of using high precision instrumentation in a dirty and difficult environment. However, entirely new approaches to karst research are being tried and discussed below. 


\section{Thermographic Mapping}

Mapping relative degrees of heat to show contrasts potentially indicating subsurface cavities has been shown to be feasible in ground-based infrared camera trials on Earth conducted in New Mexico, West Virginia, Missouri, Greece, and the Atacama Desert, Chile, and balloon-borne trials conducted in the Mojave Desert, CA (Thompson and Marvin, 2006). Modeling efforts have been mounted to study the Martian thermal environment to determine suitability of this method in the much colder temperatures of Mars with lower temperature contrast between inside and outside cavities (Wynne and others, 2008). Applicability to ultra low-temperature bodies with minimal thermal contrast remains to be demonstrated: Titan, which has a very dense atmosphere, or Enceladus and Europa, both of which have virtually no atmospheres.

\section{Imaging}

Miyamoto and colleagues (2005) have been developing a ground penetrating radar (GPR) system with shielded antennas and steppedfrequency capability (50-500 MHz) that will enable both significant penetration depth $(>10$ $\mathrm{m})$ and high spatial resolution $(<1 \mathrm{~m})$ at the same time. They field tested the instrument in a lava tube (Koumoriana, Aokigahara lava flow, Japan), and is also applicable to karst as well.

Recently a team from the NASA Jet Propulsion Laboratory analyzed interferometric synthetic aperture radar (InSAR) imagery of the area around a giant sinkhole that opened up in Bayou Corne, LA, in 2011 (Jones and Blom, 2014). Uninhabited Airborne Vehicle Synthetic Aperture Radar (UAVSAR) is mounted on a C$20 \mathrm{~A}$ jet. The InSAR instrument can measure tiny deformations in a planet's surface, and very small horizontal surface irregularities have now been shown to precede the development of a sinkhole far in advance of its collapse, potentially providing a predictive capability for Earth applications and possibly a detection method for other planets.

Radar imaging of gigantic frigid Titan, orbiting Saturn, suggests both cryovolcanism (e.g. Wall and others, 2009) and subsurface structures (Burr and others, 2009). Can processes on a body of water-ice bedrock and a surface of a bizarre mixture of organic compounds awash with alkane lakes and rain possibly produce structures like caves and karstic terrain familiar to us on Earth and other rocky terrestrial bodies? A plausibility argument can be made and tested using orbital radar imaging data and modeling.

Even more futuristically, muon imaging may provide ultra-deep penetration $(\sim 1 \mathrm{~km})$. The technique, which relies on the production of muons by collision of galactic cosmic rays with the atmosphere has already been tested for volcanology, archeology, and national security applications, and has recently been suggested for imaging the interior of small solar system bodies like asteroids or comets (Prettyman, 2013). A preliminary (Phase I) study has been funded by NASA to explore the possibilities. While the muon production rate is slow, meaning long signal collection times of days to weeks, caves are usually not moving targets and so may be perfect for such a leisurely approach!

\section{Robotics for Cave Access}

Successful robotic access to caves, rock shelters, and other rugged and unpredictable surface terrain is essential to allow exploration of other planets and even for some extreme Earth sites. Concepts like hopping, selfdeploying microbots with high energy-density power and polymer "muscle" actuated motion for subsurface sensing and telemetering networks have been suggested and developed to an early stage (Dubowsky and others, 2004). Unique clinging and climbing mechanisms also are being developed (Parness, 2010). A field demonstration with Jet Propulsion Laboratory colleagues during 2014 tested gravityindependent inverted clinging robots in lava caves in New Mexico and California and will continue into mid-2016 to investigate methods of advanced mobility.

\section{SUMMARY}

In summary, speleology is a place-based field of tremendous depth that has often been marginalized from mainstream science, especially in the United States. Over a decade ago, I wrote of the then-new National Cave and Karst Research Institute (NCKRI) and its aspirations for the future (Boston, 2003). Five years later, at the 2008 Karst Interest Group 
meeting, I attempted to further expand on our grasp of how we can be useful to the karst community and the directions to follow in accomplishing our mission. It is now time to reassess and possibly to reposition ourselves to proactively advocate for the cutting edge areas of research and application that will matter the most to the future of the field and applications. The past decade has seen emergence of a suite of research directions that map an exciting future in karst studies as we go into the next century of science and exploration. NCKRI stands ready to assist in the development of this future.

Table 1. Fundamental physical and chemical process classification of caves including karst, karst-like processes, and non-karst mechanisms for karst formation. Revised and updated from Boston, 2004.

\begin{tabular}{|c|c|c|c|}
\hline Site Tvpe & Possible Parent Material & Earth Formation Mechanisms & Possible Unique ET Mechanisms \\
\hline $\begin{array}{l}\text { Solutional Caves } \\
\text { (True "Karst") }\end{array}$ & Soluble rock & Dissolution of rock bv solvent & \\
\hline Eniaenic caves & $\begin{array}{l}\text { Limestone dolomite avosum. } \\
\text { other soluble rocks or minerals }\end{array}$ & $\begin{array}{l}\text { Weak carbonic acid faroundwater or } \\
\text { rain and dissolved } \mathrm{CO}_{2} \text { l. oraanic acids }\end{array}$ & $\begin{array}{l}\text { Other non-water liauid solvents. e. a. liauid } \\
\mathrm{CO}_{2} \text { on Mars. or liauid } \mathrm{N}_{2} \text { on Titan }\end{array}$ \\
\hline Hvpodenic caves & $\begin{array}{l}\text { Limestone. dolomite. avosum. } \\
\text { other soluble rocks or minerals }\end{array}$ & $\begin{array}{l}\text { Strona sulfuric acid (subsurface } \mathrm{H}_{2} \mathrm{~S} \text { in } \\
\text { solution at water tablel }\end{array}$ & $\begin{array}{l}\text { Sulfur-rich crust. e.a. on Mars. mav make } \\
\text { hvpodenic caves more likelv }\end{array}$ \\
\hline Other karstic caves & $\begin{array}{l}\text { Quartzite. sandstone. arkoses. } \\
\text { opalinized silicates. etc. }\end{array}$ & $\begin{array}{l}\text { Water dissolution of parent rock. } \\
\text { decementation. tafoni formation }\end{array}$ & $\begin{array}{l}\text { Other non-water liauid solvents. e. a. liauid } \\
\mathrm{CO}_{2} \text { on Mars. or liauid } \mathrm{N}_{2} \text { on Titan }\end{array}$ \\
\hline $\begin{array}{l}\text { "Pseudokarst" } \\
\text { Caves }\end{array}$ & $\begin{array}{l}\text { Meltable or vaporizable } \\
\text { solid }\end{array}$ & $\begin{array}{l}\text { Meltina or other phase } \\
\text { transition }\end{array}$ & \\
\hline Lava tubes or bubbles & Basalt. andesite. etc. & $\begin{array}{l}\text { Molten rock with differential coolina of } \\
\text { outer surface }\end{array}$ & $\begin{array}{l}\text { Scale of tubes laraer than Earth in lower } \\
\text { aravitational fields. e.a. } 0.38 \text { a on Mars }\end{array}$ \\
\hline Sub-ice volcanic caves & $\begin{array}{l}\text { sIce masses overla vina volcanic } \\
\text { terrain }\end{array}$ & Lava/ice or lava/permafrost interactions & $\begin{array}{l}\text { Lava interactions with } \mathrm{CO}_{2} \text { ice or ice-clathrate } \\
\text { interactions. around ice sublimation }\end{array}$ \\
\hline Glacier caves & Ice masses & $\begin{array}{l}\text { Thermal and pressure-induced } \\
\text { localized meltina in water ice }\end{array}$ & $\begin{array}{l}\text { Meltina in super-cooled water ice. and other } \\
\text { ices. e.a. } \mathrm{CO}_{2} \text {. methane or ammonia ice }\end{array}$ \\
\hline Ice volcanism & $\begin{array}{l}\text { Ice crusts with subsurface } \\
\text { liauid and/or vapor }\end{array}$ & None known for Earth & $\begin{array}{l}\text { Ice-covered bodies. e. a. Europa. Callisto. } \\
\text { other outer planets' mo ons }\end{array}$ \\
\hline Subsidence caves & $\begin{array}{l}\text { Permafrost. ice/se diment } \\
\text { comblexes }\end{array}$ & Permafrost voids & $\begin{array}{l}\text { Ground ice sanpina and subsequent collapse } \\
\text { and void formation on Mars or cold moons }\end{array}$ \\
\hline Volatile labvrinths & Icv breccia or rubble & None known for Earth & $\begin{array}{l}\text { Sublimation or boilina of around ices. e.a on } \\
\text { nerihelion passade bv comets }\end{array}$ \\
\hline $\begin{array}{l}\text { Tectonic and } \\
\text { Fracture Caves }\end{array}$ & Solid rock and ices & $\begin{array}{l}\text { Faulting, rifting. other tectonic } \\
\text { movements }\end{array}$ & $\begin{array}{l}\text { Cratering and subsequent } \\
\text { fracturing }\end{array}$ \\
\hline Erosional Caves & Solid materials & Weatherina effects & \\
\hline Pinina Caves & Unconsolidated materials & $\begin{array}{l}\text { Subsurface erosion of particles bv } \\
\text { water. "suffosion" in arid environments }\end{array}$ & $\begin{array}{l}\text { Subsurface erosion of particles bv non-water } \\
\text { solvents }\end{array}$ \\
\hline Sea caves & Solid rock. welded tuff. ice & $\begin{array}{l}\text { Water action (waves. floods) aqainst } \\
\text { rock }\end{array}$ & $\begin{array}{l}\text { Massive flood events. e.a. on Mars } \\
\text { Larae bodies of water in the aeoloaical past }\end{array}$ \\
\hline Wind-scoured caves & Solid rock. welded tuff. ice & $\begin{array}{l}\text { Wind blastina of abrasive particles } \\
\text { against rock }\end{array}$ & $\begin{array}{l}\text { Global or re aional dust storms on Mars } \\
\text { Aeolian caves on Venus }\end{array}$ \\
\hline Thermokinetic caves & Solid rock & $\begin{array}{l}\text { Thermal expansion and contraction. } \\
\text { spallina. exfoliation }\end{array}$ & $\begin{array}{l}\text { Thermal re aimes and uniaue phwsical effects } \\
\text { much hotter and much colder than earth. }\end{array}$ \\
\hline
\end{tabular}

\section{REFERENCES}

Andrejchuk, V.N., 1996, Gypsum karst of the preUral region. 285-292, in Klimchouk A.B., Lowe, D.J., Cooper, A.H., and Sauro, U., eds., Gypsum karst of the world. Intl J Speleology Theme issue 25 (3-4).

Banfield, J.F., and Nealson, K.H., 1997, Geomicrobiology Reviews Mineralogy, v. 35. Geol. Soc. of Amer., Boulder, CO., 448 p.

Banwart, S.A, Chorover, J., Gaillardet, J., Sparks, D., White, T., Anderson, S., Aufdenkampe, A., Bernasconi, S., Brantley, S.L., Chadwick, O., Dietrich, W.E., Duffy, C., Goldhaber, M., Lehnert, K., Nikolaidis, N.P., and Ragnarsdottir, K.V., 2013, Sustaining Earth's Critical Zones: Basic Science and Interdisciplinary Solutions for Global Challenges, Univ Sheffield, UK., 47 p.
Bar-Matthews, M., Ayalon, A., Matthews, A., Sass, E., and Halicz, L., 1996, Carbon and oxygen study of the active water-carbonate system in a karstic Mediterranean cave: Implications for paleoclimate research in semiarid regions. Geochim Cosmochim Acta 60(2): p. 337-347.

Battin, T.J., Sloan, W.T., Kjelleberg, S., Daims, H., Head, I.M., Curtis, T.P. and Eberl, L., 2007, Microbial landscapes: new paths to biofilm research. Nature Revs: Microbiol 5:76-81.

Bosák, P., Bruthans, J., Filippi, M., Svoboda, T., and Jakub, S., 1999, Karst and caves in salt diapirs, SE Zagros Mts. (Iran). ACTA Carsologica 28/2(2):41-75.

Boston, P.J., 2002, The real River Styx: The karstcontrolled biogeography of subsurface life? 
Rivers in Karst, Geol. Soc. Amer. Ann. Mtg., Denver, CO., Paper 71-1.

Boston, P.J., 2003, The National Cave and Karst Research Institute: American speleology's remarkable opportunity. J Cave Karst Stud 65(1):87-88.

Boston, P.J., 2004, Extraterrestrial Caves, Encyclopedia Cave Karst. Sci, Fitzroy-Dearborn Publ, Ltd., London, UK. p. 355-358.

Boston, P.J., and Spilde M.N., Northup, D.E., Melim, L.A., Soroka, D.S., Kleina, L.G., Lavoie, K.H., Hose, L.D., Mallory, L.M., Dahm, C.N., Crossey, L.J., and Schelble, R.T., 2001, Cave biosignature suites: Microbes, minerals and Mars. Astrobiol J 1(1):25-55.

Boston, P.J., Summers-Engel, A., Barton, H.A., Northup, D.E., Curry, M.C., and Spilde, M.N., 2009a, Geomicrobiology of Caves, in, A. N. and M.V. Palmer, eds., Caves and Karst of the USA. Nat Speleo Soc Press, Huntsville, AL. p. 403-410.

Boston, P.J., Spilde, M.N., Northup, D.E., Curry, M.D., Melim, L.A., and Rosales-Lagarde, L., 2009b, Micro-organisms as speleogenetic agents: Geochemical diversity but geomicrobial unity; in, A.B. Klimchouk and D.C. Ford, eds., Hypogene Speleogenesis, Karst Hydrology of Artesian Basins. Sp Pap 1:51-57. Ukr Inst Speleol Karstol, Simferopol, Ukr 280 p.

Burr, D.M., Jacobsen, R.E., Roth, D.L., Phillips, C.B., Mitchell, K.L., and Viola, D., 2009, Fluvial network analysis on Titan: Evidence for subsurface structures and west-to-east wind flow, southwestern Xanadu, Geophys Res Lett, v. 36, Is. 22.

Cams, I., 1989, A new definition of karst, in Gillieson D. and Smith D.I. eds, Resource management in limestone landscapes: International Perspectives. Sp Pub No. 2, Dept Geography Oceanography, Canberra: Australian Defence Force Academy, 165-171.

Carrion, J.S., Munuera, M., Navarro, C., Burjachs, F., Dupre, M., and Walker, M.J., 1999, The palaeoecoloical potential of pollen records in caves: the case of Mediterranean Spain: Quaternary Sci Revs 18(8-9):1061-1073.

Chabert C., and Courbon P., 1997, Atlas de cavités non calcaires du monde, Un Int Spéléol au prés Madame Carle: 1-120. Paris.

Chalcraft D., and Pye K., 1984, Humid tropical weathering of quartzite in southeastern
Venezuela, Zeilschrift fur Geomorphologie 28:321-332.

Chivian, D., Brodie, E.L., Alm, E.J., Culley, D.E., Dehal, P.S., DeSantis, T.Z., Gihring, T.M., Lapidus, A., Lin, L. Lowry, S.R., Moser, D.P., Richardson, P.M., Southam, G., Wanger, G., Pratt, L.M., Andersen, G.L., Hazen. T.C., Brockman, F.J., Arkin, A.P., and Onstott, T.C., 2008, Environmental genomics reveals a singlespecies ecosystem deep within earth. Science 322:275-278.

Colcutt, S., 1979, The analysis of Quaternary cave sediments. World Archaeology 10:290-301.

Couchard, I., 2008, Speleothems as archives of paleoenvironmental change. Quaternaire 19(4):255274.

Cowan, J.P., Giovannoni, S.J., Kenig, F., Johnson, H.P., Butterfield, D., Rappe, M.S., Hutnak, M., and Lam, P., 2003, Fluids from aging ocean crust that support microbial life, Science 299:120-123.

Curry, M., Boston, P.J., Spilde, M.N., Baichtal, J., and Campbell, A., 2009, Cottonballs: A unique subaqueous moonmilk, and abundant subaerial moonmilk in Cataract Cave, Tongass National Forest, Alaska. Intl J Speleol 38(2):111-128.

Cushing, G.E., 2012, Candidate cave entrances on Mars. J Cave Karst Stud 74(1):33-47.

Cushing, G.E., Titus, T.N., Wynne, J.J., and Christensen, P.R., 2007, THEMIS observes possible cave skylights on Mars. Geophys Res Lett 34(17):L17201.

Day, C.C., and Henderson, G.M., 2013, Controls on trace-element partitioning in cave-analogue calcite. Geochim Cosmochim Acta 120:612-627.

Dreybrodt W., 1988, Processes in karst systems, Springer, Berlin, Germany, 288 p.

Dubowsky, S., Iagnemma, K., and Boston, P.J., 2004, Microbots for large-scale planetary surface and subsurface exploration. CP 02-02, http://www.niac.usra.edu/files/studies/dubowsky

Einaudi M.T., and Burt D.M., 1982, Introduction, terminology, classification and composition of skarn deposits, Economic Geology 77L745-754.

Enders, M.S., Southam, G., Knickerbocker, C., and Titley, S.R., 2006, The role of microorganisms in the super-gene environment of the Morenci porphyry copper deposit, Greenlee County, AZ, Econ Geol 101:59-70. 
Fairchild, I.J., Smith, C.L., Baker, A., Fuller, L., Spotl, C., Mattey, D., McDermott, F., and the Edinburgh Ion Microprobe Facility, 2006, Modification and preservation of environmental signals in speleothems: Earth-Sci Revs 75:105153.

Ford, D.C., 1980, Threshold and limit effects in karst geomorphology, in, Coates D. R. and Vitek J. D., eds, Thresholds in Geomorphology, Allen and Unwin, London, UK. p. 345-362.

Ford D.C., and Williams P.W., 1989, Karst Geomorphology and Hydrology, Unwin Hyman, London, UK, 601 p.

Ford, D.C., and Williams, P., 2007, Karst hydrogeology and geomorphology, John Wiley and Sons Ltd.

Fredrickson, J.K., and D. Balkwill, 2006, Geomicrobial processes and biodiversity in the deep terrestrial subsurface, Geomicrobiol J 23:345-356.

Frumkin A., 1994, Hydrology and denudation rates of halite karst, J Hydrol 162:171-189.

Garcia-Pichel, F., Ramírez-Reinat, E., and Gao, Q., 2010, Microbial excavation of solid carbonates powered by P-type ATPase-mediated transcellular $\mathrm{Ca} 2+$ transport. Proc Nat Acad Sci 107(50):21749-21754.

Gascoyne, M., 1992, Paleoclimate determination from cave calcite deposits, Quatern Sci Revs 11(6):609-632.

Ghosh, P., and Brand, W.A., 2003, Stable isotope ratio mass spectrometry in global climate change research, Intl J Mass Spectrom 228:1-33.

Gibbs, A.K., and Barron, C.N., 1993, The geology of the Guyana Shield, Oxford Monogr Geology and Geophysics, 22, 246 p.

Gihring, T.M., Moser, D.P., Lin, L.-H., Davidson, M., Onstott, T.C., Morgan, L., Milleson, M., Kieft, T.L., Trimarco, E., Balkwill, D.L., and Dollhopf, M.E., 2006, The distribution of microbial taxa in the subsurface water of the Kalahari Shield, South Africa. Geomicrobiol J 23:415-430.

Golubic, S., Friedmann, I., and Schneider, J., 1981, The lithobiotic ecological niche, with special reference to microorganisms. J Sediment Petrol 51, 475-478.
Greeley, R., 1971, Lava tubes and channels in the lunar Marius Hills, Earth Moon Planets 3:289314.

Grin, E.A., Cabrol, N.A., and McKay, C.P., 1998, Caves in the Martian regolith and significance for exobiology exploration, 29th Ann Lunar Planet Sci Conf, Houston, TX. Abstr 1012.

Grin, E.A., Cabrol, N.A., and McKay, C.P., 1999, The hypothesis of caves on Mars revisited through MGS data: Potential as targets for surveyor program. Wkshp Mars 2001: Integrated Sci in Prep for Sample Return and Human Exploration, 2-4 Oct. 1999, Lunar Planet Inst, Houston, TX., 31-33.

Hall-Stoodley, L., Costerton, J.W., and Stoodley, P., 2004, Bacterial biofilms: From the natural environment to infectious disease. Nature Revs Microbiol 2(2):95-108.

Haruyama, J., Hioki, K., Shirao, M., Morota, T., Hiesinger, H., van der Bogert, C.H., Miyamoto, H., Iwasaki, A., Yokota, Y., Ohtake, M., Matsunaga, T., Hara, S., Nakanotani, S., and Pieters, C.M., 2009, Possible lunar lava tube skylight observed by SELENE cameras. Geophys Res Lett v. 36: Is. 21.

Huang, Y.M., Fairchild, I.J., Borsato, A., Frisia, S., Cassidy, N.J., McDermott, F., and Hawkesworth, C.J., 2001a, Seasonal variations in Sr, Mg and P in modern speleothems (Grotta di Ernesto, Italy), Chem Geol 175(3-4): 429-448.

Huang Y.M., and Fairchild, I.J., 2001, Partitioning of Sr2 and Mg2 into calcite under karst-analogue experimental conditions, Geochim Cosmochim Acta 65(1):47-62.

Johnson K.R., Hu C.Y., Belshaw, N.S., and Henderson G.M., 2006, Seasonal trace-element and stable-isotope variations in a Chinese speleothem: Potential for high-resolution paleomonsoon reconstruction, Earth Planet Sci Lett 244(1-2):394-407.

Jones, C.E., and Blom, R.G., 2014, Bayou Corne, Louisiana, sinkhole: Precursory deformation measured by radar interferometry. Geology 42:111-114.

Karthikeyan, S., and Beveridge, T.J., 2002, Pseudomonas aeruginosa biofilms react with and precipitate toxic soluble gold, Environm Microbiol 4(11):667-675. 
Kieft, T.L., 2000, Size matters: dwarf cells in soil and subsurface terrestrial environments, Ch. 3, in R.R. Colwell and D.J. Grimes, eds., Non-culturable microorganisms in the environment, Amer Soc Microbiol, Washington, D.C. p. 19-46.

Kieft, T.L., 2002, Microbial starvation survival in subsurface environments, in G. Bitton, ed., Encyclopedia Environmental Microbiology, John Wiley, NY. p. 2019-2028.

Kieft, T.L., and Phelps, T.J., 1997, Life in the slow lane: Activities of microorganisms in the subsurface, in The microbiology of the terrestrial subsurface. P. S. Amy and D. L. Haldeman, eds, CRC Press, Boca Raton, FL.

Klimchouk A.B., and Andrejchuk, V.N., 2002, Karst breakdown mechanisms from observations in the gypsum caves of the Western Ukraine: Implications for subsidence hazard assessment, in, Klimchouk A. and Lowe D., eds, Implication of Speleological Studies for Karst Subsidence Hazard Assessment. Intl J Speleol, Theme issue, N 31 (1-4):55-89.

Klimchouk, A.B., Lowe, D.J., Cooper, A.H., and Sauro, U. eds, 1996, Gypsum karst of the world, Intl J Speleol, Theme issue, N 25 (3-4).

Larsen, P., 2003, Scientific accounts of a vanishing lake: Janez Valvasor, Lake Cerknica, and the New Philosophy, MS Thesis, Linacre College, Univ. of Oxford, UK.

Lengke, M.F., and Southam, G., 2006, Bioaccumulation of gold by sulfate-reducing bacteria cultured in the presence of goldthiosulfate complex, Geochim Cosmochim Acta 70: 3646-3661.

Lin, L.-H., Wang, P.-L., Rumble, D., LippmannPipke, J., Boice, E., Pratt, L.M., Sherwood-Lollar, B., Brodie, E.L., and Hazen, T.C., Andersen, G.L., DeSantis, T.Z., Moser, D.P., Kershaw, D., and Onstott, T.C., 2006, Long-term sustainability of a high-energy, low-diversity crustal biome. Science 314:479-482.

Malaska, M., Radebaugh, J., Mitchell, K., Lopes, R., Wall, S., and Lorenz, R., 2011, Surface dissolution model for Titan karst, in First Intl Planet Caves Wkshp, Nat Cave Karst Res Inst, Carlsbad, NM, Oct 2011, Abstr 8018.

Martin, J.B., and White, W.B., 2008, Frontiers of karst research: Proceedings and recommendations, Spec Publ 13, Karst Waters Institute, Inc., Leesburg, VA.
Martínez, G.A., Mazzanti, D.L., Quintana, C., Zucol, A.F., de los Milagros, M., Hassan, G.S., Brea, M., and Passeggi, E., 2013, Geoarchaeological and paleoenvironmental context of the human settlement in the Eastern Tandilia Range, Argentina. Quaternary Intl, v. 299: p. 23-37.

McGarry, S.F., and Caseldine, C., 2004, Speleothem palynology: An undervalued tool in Quaternary studies. Quatern Sci Revs, 23(23-24):2389-2404.

Melim, L.A., Shinglman, K.M., Boston, P.J., Northup, D.E., Spilde, M.N., and Queen, J.M., 2001, Evidence of microbial involvement in pool finger precipitation, Hidden Cave, NM. Geomicrobiol Journal 18:311-330.

Melim, L.A., Northup, D.E., Spilde, M.N., Jones, B, Boston, P.J., and Bixby, R.J., 2008, Reticulated filaments in cave pool speleothems: Microbe or mineral? Journal of Cave and Karst Studies v. 70:135-141.

Melim, L.A., Liescheidt, R., Northup, D.E., Spilde, M.N., Boston, P.J., and Queen, J.M., 2009, A biosignature suite from cave pool precipitates, Cottonwood Cave, New Mexico. Astrobiology 9(9):907-917.

Mitchell, K., and Malaska, M., 2011, Karst on Titan, in, First Intl Planet Caves Wkshp, Nat Cave Karst Res Inst, Carlsbad, NM, Oct 2011, Abstr 8021.

Miyamoto, H., Haruyama, J., Kobayashi, T., Suzuki, K., Okada, T., Nishibori, T., Showman, A.P., Lorenz, R., Mogi, K., Crown, D.A., Rodriguez, J.A.P., Rokugawa, S., Tokunaga, T., and Masumoto, K., 2005, Mapping the structure and depth of lava tubes using ground penetrating radar. Geophysl Res Lett 32:L21316.

Monroe, W.H., 1970, A glossary of karst terminology: U.S. Geological Survey, WaterSupply Paper 1899, 26 p.

Morris, L.R., West, N.E., Baker, F.A., Van Miegroet, H., and Ryel, R.J., 2009, Developing an approach for using the soil phytolith record to infer vegetation and disturbance regime changes over the past 200 years. Quaternary Intl 193:90-98.

National Research Council, 2001, Basic Research Opportunities in the Earth Sciences, Nat Acad Press, Washington, D.C.

Newman, D.K., and Banfield, J.F., 2002, Geomicrobiology: How molecular-scale interactions underpin biogeochemical systems, Science 296: 1071-1077. 
Northup, D.E., and Lavoie, K.H., 2001, Geomicrobiology of caves: A review, Geomicrobiol J 18:199-222.

Oberbeck, V., Quaide W., and Greeley, R., 1969, On the origin of Lunar sinuous rilles, Modern Geol 1:75-80.

Palmer, A.N., 2009, Cave Geology, 2nd Printing, Cave Books, Trenton, N.J.

Parness, A., 2010, Microstructured adhesives for climbing applications, PhD Dissertation, Stanford University.

Patrick, E.L., Mandt, K.E., Mitchell, E.J., Mitchell, J.N., Younkin, K.N., Seifert, C.M., and Williams, G.C., 2012, A prototype mass spectrometer for in situ analysis of cave atmospheres. Revs Sci Instrum 83:105116(1-12).

Piccini L., 1995, Karst in siliceous rocks: Karst landforms and caves in the Auyan-Tepui Massif, Int J Speleol 24(Phys):1-4.

Poulson, T.L., Keith, J.H., and Lavoie, K.H., 1986, Biological deserts under the caprock, 1985 Ann Rep Cave Res Found, p. 24-25.

Prettyman, T., 2013, Deep mapping of small solar system bodies with galactic cosmic ray secondary particle showers.

http://www.nasa.gov/content/deep-mapping-ofsmall-solar-system-bodies-with-galactic-cosmicray-secondary-particle/\#.UyY879ybFzO

Rawlings, D.E., and Johnson, D.B., 2007, The microbiology of biomining; Development and optimization of mineral-oxidizing microbial consortia. Microbiol 153:315-324.

Sakimoto, S.E.H., Crisp, J., and Baloga, S.M., 1997, Eruption constraints on tube-fed planetary lava flows, J Geophys Res 102:6597-6613.

Scott, L., 2002, Grassland development under glacial and interglacial conditions in southern Africa: review of pollen, phytolith and isotope evidence, Paleogeog Palaeoclimatol Palaeoecol 177(12):47-57.

Self, C.A., and Mullan G.J., 1996, Redefining the boundary between karst and pseudokarst. Cave Karst Sci 23(2): 63-70.

Shannon, M.J.R., and Unterman, R., 1993, Evaluating bioremediation, Ann Rev Microbiol 47:715-730.

Southam, G., Lengke, M.F., Fairbrother, L., and Reith, F., 2009, Biogeochemistry of gold, Elements 5:303-307.
Southam, G., and Saunders, J.A., 2005, The geomicrobiology of ore deposits, Econ Geol 100:1067-1084.

Thompson, J., and Marvin, M., 2006, Experimental research using thermography to locate heat signatures from caves, Proc $17^{\text {th }}$ Nat Cave Karst Mgmt Symp, Albany, NY. p. 102-115.

Treble, P.C., Chappell, J., and Shelley, J.M.G., 2005, Complex speleothem growth processes revealed by trace element mapping and scanning electron microscopy of annual layers. Geochim Cosmochim Acta 69(20):4855-4863.

Trombold, C.D., and Israde-Alcantara, I., 2005, Paleoenvironment and plant cultivation on terraces at La Quemada, Zacatecas, Mexico: the pollen, phytolith and diatom evidence, J Archaeol Sci 32:341-353.

Wall, S.D., Lopes, R.M., Stofan, E.R., Wood, C.A., Radebaugh, J.L., Horst, S.M., Stiles, B.W., Nelson, R.M., Kamp, L.M., Janssen, M.A., Lorenz, R.D., Lunine, J.I., Farr, T.G., Mitri, G., Paillou, P., Raganelli, F., and Mitchell, K.L., 2009, Cassini RADAR images at Hotei Arcus and western Xanadu, Titan: Evidence for geologically recent cryovolcanic activity. Geophys Res Lett, v. 36:L04203.

Woodhead, J., Reisz, R., Fox, D., Drysdale, R., Hellstrom, J., Maas, R., Cheng, H., and Edwards, R.L., 2010, Speleothem climate records from deep time? Exploring the potential with an example from the Permian, Geology v. 38(5): p. 455-458.

Wray R.A.L., 1997, Quartzite dissolution: karst or pseudokarst? Cave Karst Sci 24(2):81-86.

Wynne, J.J., Titus, T.N., and Chong Diaz, G., 2008, On developing thermal cave detection techniques for Earth, the Moon, and Mars. Planet Sci Lett 272(1):240-250.

Wyrick, D., Ferrill, D.A., Morris, A.P., Colton, S.L., and Sims, D.W., 2004, Distribution, morphology, and origins of Martian pit crater chains. J Geophys Res E: Planets 109:E06005.

Zhou, Y.F., Wang, R.C., and Lu, X.C., 2011, Anorthite (Ca Feldspar) dissolution promoted by bacterial adhesion: Direct evidence from dialytic experiment, Science China - Earth Sci 54(2):204211. 


\title{
PROGRAMS AND KARST AQUIFERS
}

\section{A Preview of "Karst in the United States of America: A Digital Map Compilation and Database"}

\author{
By David J. Weary and Daniel H. Doctor \\ U.S. Geological Survey, 12201 Sunrise Valley Drive, MS926A, Reston, VA 20192
}

\begin{abstract}
A series of new digital maps delineating areas of known and potential karst and pseudokarst development in the United States, including Puerto Rico and the U.S. Virgin Islands, have been compiled and are being released as a U.S. Geological Survey Open-File Report (OFR). These maps show areas underlain by soluble rocks with potential for karst development as well as volcanic rocks, sedimentary deposits, and permafrost with potential for pseudokarst development. Data indicate that all 50 States contain areas with potential for karst development. About 18 percent of the area of the United States is underlain by karst or soluble rocks that have the potential for karst development. The mapped areas of soluble rocks, containing significant amounts of carbonate or evaporite minerals, are primarily based on their distribution shown on state geologic maps. Areas underlain by soluble rocks are further classified by general climate setting, induration, and exposure. Areas with potential for volcanic pseudokarst are those chiefly underlain by basaltic extrusive rocks no older than Miocene in age. Potential pseudokarstic features in unconsolidated sedimentary rocks include piping caves. Areas with potential for development of thermokarst subsidence features in Alaska contain permafrost mantled by various thicknesses of sediment. The OFR includes a GIS database with links from the map unit polygons to online geologic unit descriptions. This paper is an interim product, and a formal publication and print edition, with revisions and additions, is planned for the near future.
\end{abstract}

\section{INTRODUCTION}

A new digital national karst map will be published as an Open-File Report (OFR) (Weary and Doctor, in press). The OFR contains extensive discussion and detailed descriptions of the processes used to compile and classify the karst data that it contains. In addition, the maps included in the OFR are both more complex and of higher resolution than the figures shown in this paper.

Because the development of karst is primarily dependent on the presence of soluble rocks, the delineation of karst was based on compiling areas of soluble rocks from geologic maps (e.g. Williams and Ford, 2006). We compiled regions of known and potential karst in the United States using the latest, most detailed published digital geologic map information. While this approach is representative of karst potential, a complex interaction of many factors determines the formation, localization, and intensity of karst development. These factors include the rock type, structural setting, climate, sedimentary cover, vegetation, local hydrologic conditions, and time. Because very sparse karst features evident at the land surface can indicate important groundwater flow processes in the subsurface, we have included all areas containing soluble bedrock types as potentially hosting karst features.

Pseudokarst (Halliday, 2007) discussed in the OFR includes areas with features analogous to karst that arise from processes other than rock solution. Potential pseudokarst includes areas underlain by geologic materials susceptible to formation of voids produced in lava flows and by erosion of fine-grained sediments by piping (stoping), and melting of permafrost. Examples include lava tubes in Miocene and younger volcanic flow rocks (primarily basalts), piping features within unconsolidated sediments in semiarid to arid regions, as well as areas of piping in sediments affected by intermittently or progressively thawing permafrost in Alaska. Pseudokarst in permafrost areas is also known as thermokarst (Sweeting, 1973). Large karst-like integrated groundwater flow systems that resurge at large springs occur in some areas of 
layered volcanic rocks in the western United States. Examples include the Columbia Plateau aquifer system in Oregon and Washington, and the Snake River Plain aquifer system in Idaho.

Five thematic maps in the report include 1) karst and potential karst areas of relatively soluble rocks (e.g. limestone, dolomite, gypsum, anhydrite, halite, etc.) exposed at the surface or buried at depths up to 300 feet in the contiguous United States, 2) karst and potential karst areas of relatively soluble rocks (e.g. limestone and dolomite) in Alaska, Hawaii, Puerto Rico, and the U.S. Virgin Islands, 3) areas underlain by evaporite rocks at varying depths up to 7,000 feet, 4) areas with potential for pseudokarst in the contiguous United States, and 5) areas with potential for pseudokarst in Alaska and Hawaii.

The extent of outcrop of soluble rocks provides a good first-approximation of the distribution of karst and potential karst areas, particularly in parts of the United States with a humid climate. Criteria for further refinement of the karst map units includes 1) climate of regions based on annual precipitation and Level III ecoregion designation, 2) degree of burial and nature of the overlying sediments, and 3 ) degree of consolidation of the lithostratigraphic unit.

The geographic information system (GIS) data that accompany the OFR represent karst areas as spatially registered polygons containing multiple attributes that allow the user to perform selection and analysis on the data. Certain attributes also allow linking back to the original lithostratigraphic unit descriptions and ecoregion descriptions.

\section{DATA SOURCES}

Most of the spatial data compiled in this project originated as lithologic map units on geologic maps produced by various state geological surveys. Versions of the original source maps are available for purchase or download from the respective state geological surveys. Much of the digital map data was compiled from a series of integrated geologic map databases for the United States produced by the United States Geological Survey (USGS) Mineral Resources Program, National Surveys and Analysis (NSA) Project (available at http://mrdata.usgs.gov/geology/state/, accessed $02 / 10 / 2014)$. Use of the USGS digital geologic data provided a consistent data structure within which a derivative database of areas with potential for karst could be constructed. Edits, deletions, and additions to this database were made based on 1) comparison to other published karst maps (principally Davies and others, 1984; Veni, 2000), 2) comments and contributions by other cave and karst researchers having local knowledge of particular areas, and assisted by the comprehensive compilation in Palmer and Palmer (2009), and 3) the personal knowledge of the authors. Further characterization of the karst areas was also accomplished via overlay analyses with other data including distribution of glacially-derived sediments (Soller and others, 2012), permanently frozen ground (Brown and others, 2002), and Level III Ecoregions (U.S. Environmental Protection Agency, 2013).

\section{MAPS}

The maps shown in figures 1-5 were generated from GIS data derived from various original geologic map sets that ranged from $1: 24,000$ to $1: 500,000$ scale. The graphic files provided in the OFR are designed for display at 1:6,000,000 scale for the contiguous United States and Alaska, and 1:3,000,000 scale for Hawaii, Puerto Rico, and the U.S. Virgin Islands. They will print at these scales at 100 percent resolution. The geographic data for all of these maps is in Albers projection using the North American Horizontal Datum of 1983.

\section{Map of Karst in Soluble Rocks in the Contiguous United States}

The distribution of karst and potential karst areas of soluble rocks in the contiguous United States is shown on figure 1 . Because of space limitations, this is a greatly simplified version of the map that will be available in the OFR.

Distribution of mature surface karst areas in the contiguous United States is primarily dependent on the presence of soluble rocks at or near the land surface and where the mean annual precipitation above approximately 30 inches (in.) (76 centimeters (cm)). In the humid parts of the United States, most karst features such as caves and sinkholes (dolines) occur in carbonate 
(limestone and dolomite) rocks; evaporite rocks are rarely found at or near the surface in these areas. Most of the eastern United States and the Pacific coastal zone are considered to be humid. Local areas of the Rocky Mountains and the Sierra Nevada are also classified as humid regions in this paper because of higher precipitation totals mostly due to orogenic effects. All areas of Alaska, Hawaii, Puerto Rico and the Virgin Islands are considered humid at the resolution of this study. In the semi-arid and arid regions of the western United States less soluble carbonate rocks are more resistant to erosion while the more soluble evaporite rocks that can exist at or near the surface in those environments, exhibit the most prominent karst features. Karst features created by hypogenic processes tend to be better preserved in arid and semi-arid areas as these features are less likely to be modified by epigenic processes in drier climates (Palmer, 2000; Auler and Smart, 2003).

Potential karst areas shown on figure 1 are grouped by areas of humid climate and areas of dry (semi-arid to arid) climates. In addition to carbonate and evaporite rocks, an area of quartz sandstone in Minnesota with documented solution karst is also shown (Shade, 2002). Other areas of anomalous solution, in what are normally considered insoluble rocks, may exist elsewhere in the United States and are yet to be documented.

For figures 1 and 3, the boundaries between dry and humid regions were delineated by comparing the average annual precipitation map for the years 1961-1990 with descriptions of North American Level III Ecoregions (Daley and Taylor, 2000; U.S. Environmental Protection Agency, 2013). These boundaries are coincident with the Level III Ecoregion boundaries and they approximate the $30 \mathrm{in}$. (76 $\mathrm{cm}$ ) per year annual average precipitation isohyet (Daley and Taylor, 2000). These boundaries, although shown as hard lines on figures 1 and 3 , are actually diffuse and approximate. The principal boundary separating the eastern from the western areas of the United States also approximates the southern part of the annual average precipitation isohyet used by Epstein and Johnson (2003). There is some divergence of the humid and dry region

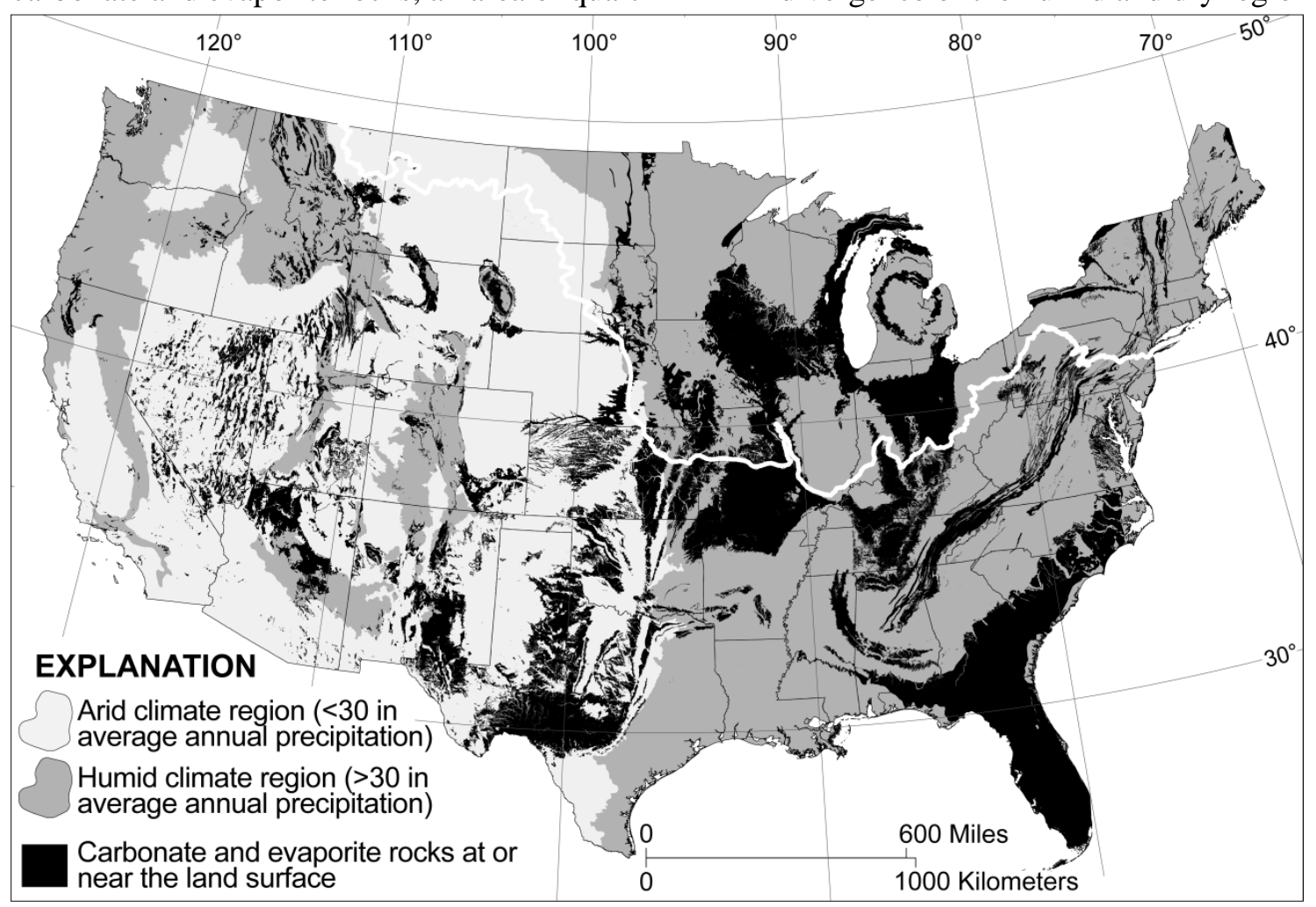

Figure 1. Simplified map of the distribution of karst and potential karst areas of soluble rocks, as well as arid, semi-arid, and humid climate regions. Thick white line indicates approximate maximum southern extent of Pleistocene ice. 
boundaries from the principal 30-inch precipitation line at both north and south latitudes, as the effective regional humidity is also a function of the regional evapotranspiration rate, which itself is affected by temperature.

Effects of late Cenozoic glaciations have a profound influence on the development and preservation of karst features in the northern and eastern parts of the contiguous United States. The line of demarcation approximating the greatest extent of the last glaciation is shown on figure 1, and the thickness of glacially-derived sediments overlying areas of soluble rocks is also integrated into the classification of map units in the OFR. The glacial data are derived from Soller and others (2012).

\section{Karst Map Units}

Space limitations preclude a detailed description of the 11 map units shown on the OFR map (not shown separately on figure 1 in this paper). Map units occurring in either a humid or arid climate regime include

- Carbonate rocks at or near the land surface

- Carbonate rocks buried beneath $<300$ feet of insoluble sediments

- Carbonate rocks buried beneath $<50$ feet of glacially-derived insoluble sediments

- Carbonate rocks buried beneath $>50$ feet of glacially-derived insoluble sediments
- Calcareous sediments at or near the land surface

- Unconsolidated calcareous sediments buried beneath $<300$ feet of insoluble sediments

- Evaporite rocks exposed at or near the land surface

- Evaporite rocks buried beneath $<50$ feet of glacially-derived insoluble sediments

- $\quad$ Evaporite rocks buried beneath $>50$ feet of glacially-derived insoluble sediments

- Quartz sandstone buried beneath $<50$ feet of glacially-derived insoluble sediments

- Quartz sandstone buried beneath $>50$ feet of glacially-derived insoluble sediments

\section{Map of Karst in Soluble Rocks in Alaska, Hawaii, Puerto Rico, and the U.S. Virgin Islands}

The distribution of potentially karstic areas of soluble rocks in Alaska, Hawaii, Puerto Rico, and the U.S. Virgin Islands is shown on figure 2. All of these areas have relatively humid climates, so evaporite rocks rarely occur at or near the surface. Areas of carbonate rocks occurring at or near the surface are shown as a single map unit on figure 2 . 


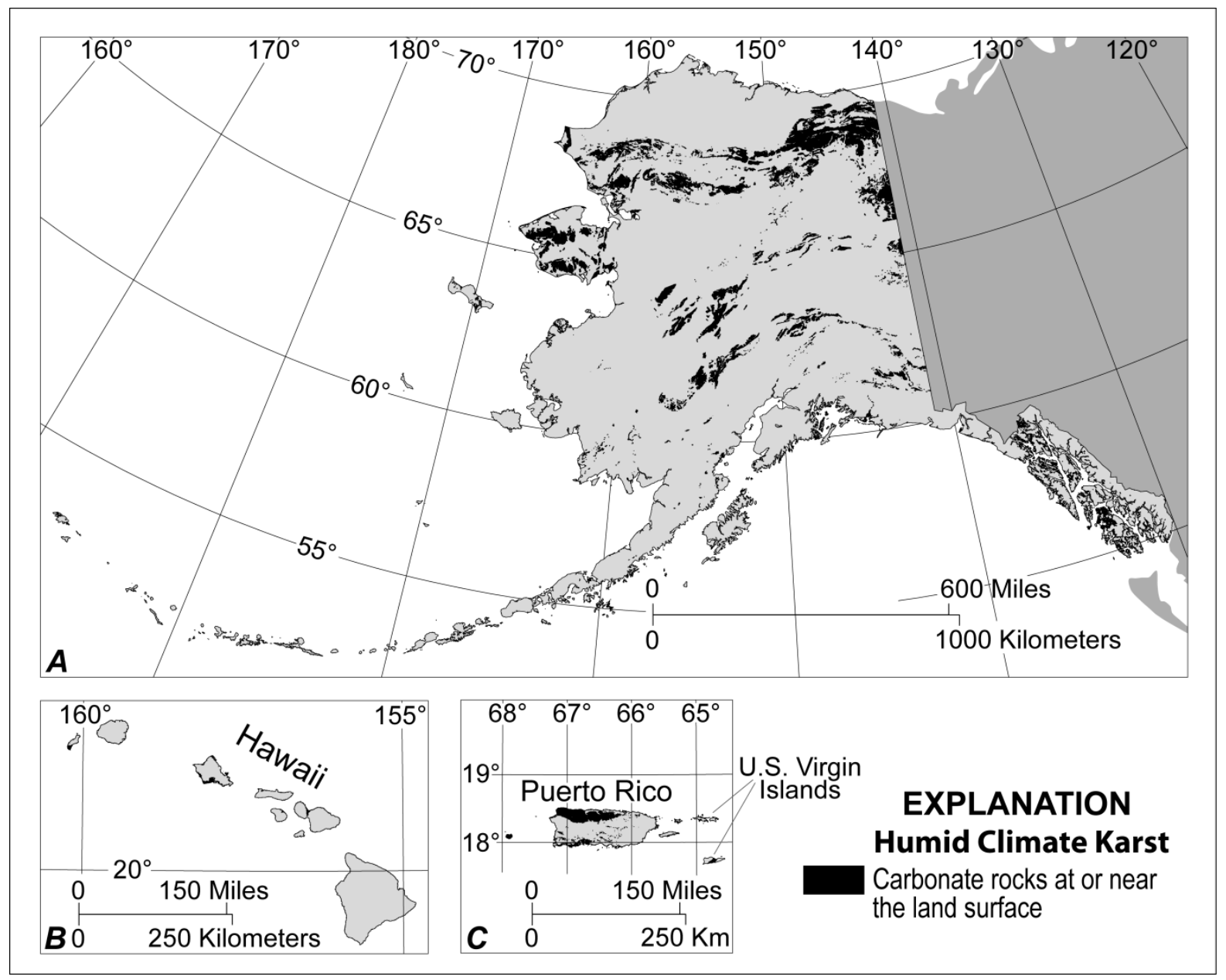

Figure 2. Simplified map of karst and potential karst areas of soluble rocks in A, Alaska; B, Hawaii; and C, Puerto Rico and the U.S. Virgin Islands.

\section{Map of Areas Extensively Underlain by Evaporite Rocks at Depths up to 7,000 Feet Below the Surface}

In addition to areas of outcropping and nearsurface evaporite rocks, figure 3 shows the extent of subsurface evaporite basins and the greater extent of commonly occurring evaporite rocks in the subsurface. The evaporite basins contain soluble rocks buried to depths of up to about 7,000 feet, but generally much less. Because of the physical properties and very high solubility of evaporite rocks, human activities such as fluid injection or leaking well casings can induce large solution voids. Collapses of these voids are known to propagate up to the surface from depths of more than 1,000 feet.

\section{Map of Pseudokarst Areas in the Contiguous United States}

Two different pseudokarst units are portrayed on the map of the contiguous United States (fig. 4). The first unit represents areas of poorly consolidated sedimentary rock units known, at least locally, to contain piping features (tubes, caves, and subsidence features). Most of the areas of piping potential are commonly characterized by fine-grained sedimentary rocks. These units are known to contain pseudokarst features; however, areas with potential for such features are probably more widespread. The second unit represents areas of volcanic rock that may contain lava tubes (vulcanokarst) and/or layered volcanic rocks with integrated fast groundwater flow systems. 


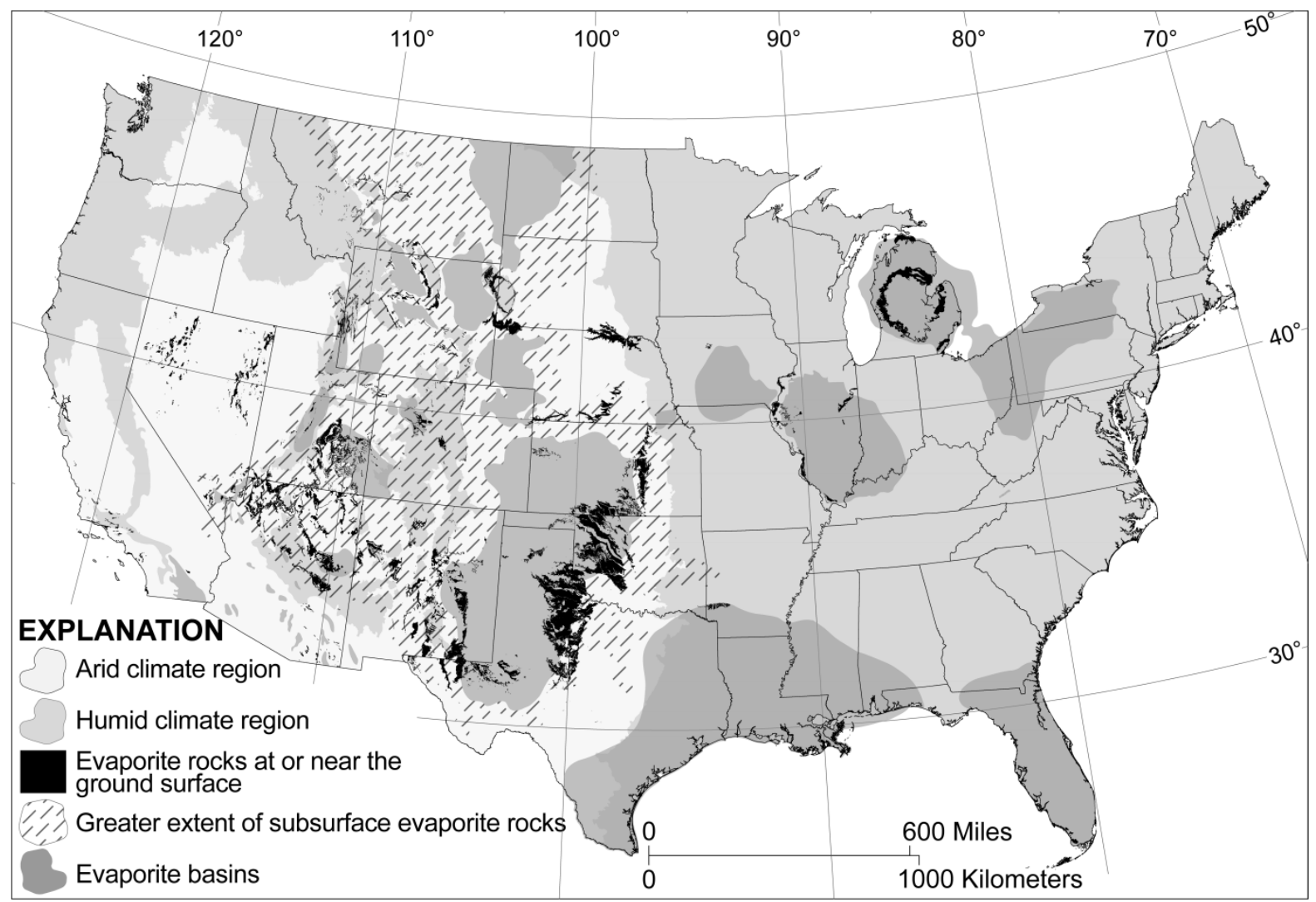

Figure 3. Simplified map of areas underlain by evaporite rocks at depths up to 7,000 feet. Arid regions receive less than about 30 inches of annual precipitation.

\section{Map of Pseudokarst Areas in Alaska and Hawaii}

Because of the relatively recent and ongoing volcanism in both Alaska and Hawaii, they contain widespread, relatively young (Miocene age or younger) lava flow deposits that contain lava tubes and other pseudokarst features (fig. 5A, B). Lava tubes form most readily and extensively in low-viscosity lava flows, generally of basaltic composition. Lava tube caves are relatively short-lived geologic features as they are 1) either filled by succeeding eruptive lavas, or 2) as near surface features they are susceptible to erosion and collapse of the overlying rocks. Lava tubes are generally not found in rocks older than Miocene age, and this age was used as a cutoff for selecting volcanic flow units for this map.
The cold climate of Alaska results in extensive regions of permafrost, or permanently frozen ground (Brown and others, 2002) (fig. 5A). As the climate warms and these areas experience melting, landforms and hydrologic conditions that are analogous to karst terrains, such as sinkholes and sinking streams result. Because this phenomenon is related to melting of ice rather than solution of bedrock, these permafrost features are considered a category of pseudokarst (Halliday, 2007) and termed thermokarst (Sweeting, 1973, p. 308).

The OFR describes several classes of thermokarst terrain, on the basis of ice quality and overlying sediment thickness. 


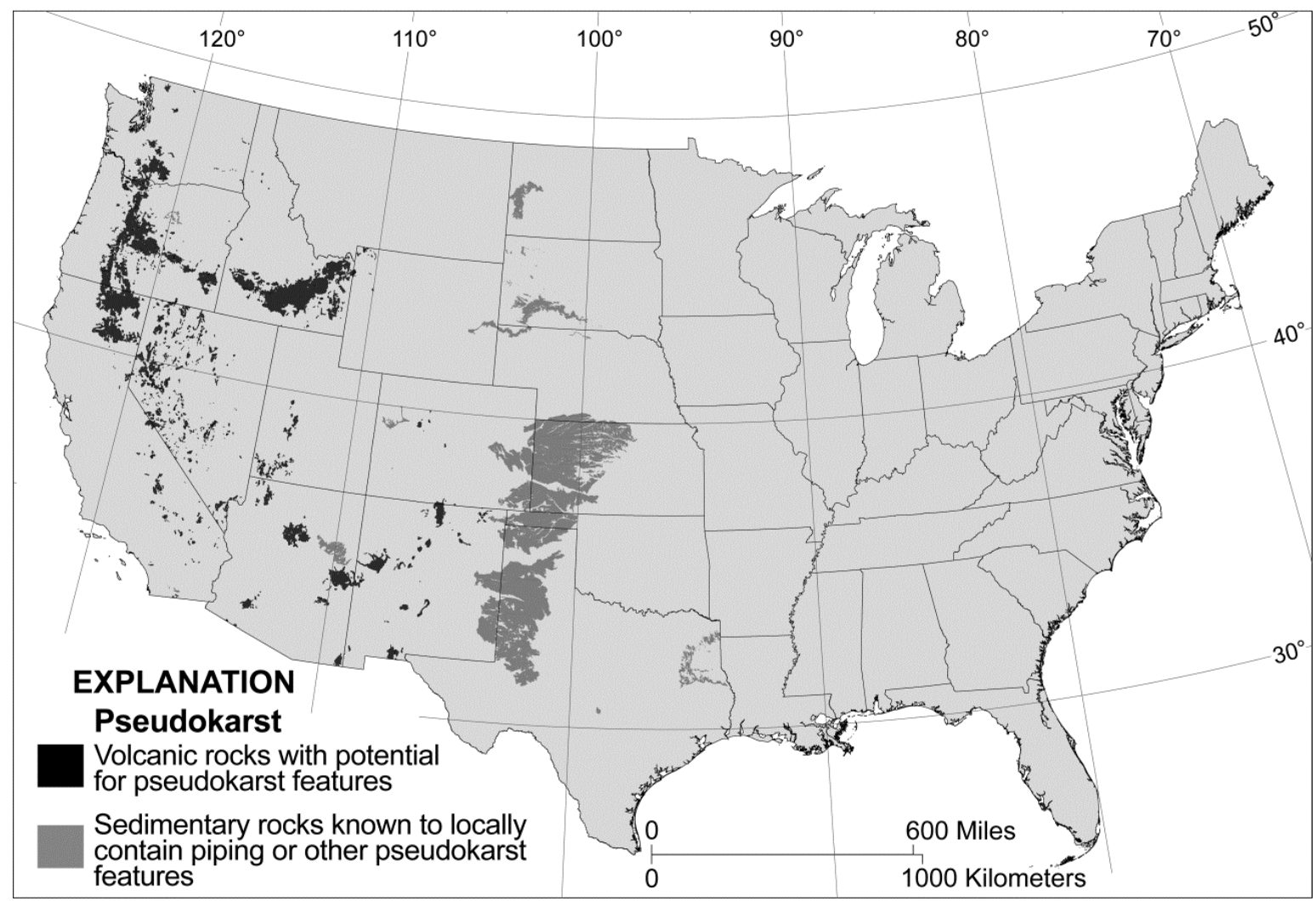

Figure 4. Areas of known pseudokarst features in the contiguous United States.

\section{SPATIAL STATISTICS}

Simple spatial statistics were used to calculate the percentage area of the United States that is underlain by the areas of karst and pseudokarst defined in the OFR. These statistics are exclusive of Puerto Rico and the U.S. Virgin Islands. The results are shown on figure 6 . In summary, about 25 percent of the United States is underlain by rocks or sediments, as previously described, with a potential for karst or pseudokarst features. About 18 percent of the United States is underlain by soluble rocks, of which 16 percent consists of carbonate rocks and the remaining 2 percent are evaporite rocks. The area of the nation underlain by basins where evaporite rocks may be encountered by deep drilling is not included in these statistics. These values underestimate the area of the United States underlain by karst aquifers, a major source of potable water for the nation. About 2 percent of the United States is underlain by sedimentary rocks prone to pseudokarst features developed primarily by piping. Almost 4 percent of the country, and entirely restricted to Alaska, is underlain by sediments and permafrost prone to development of thermokarst. Lastly, about 1.5 percent of the total area of the United States, which includes areas in the western part of the contiguous United States, Alaska, and Hawaii, are underlain by volcanic rocks with potential for lava tubes. 


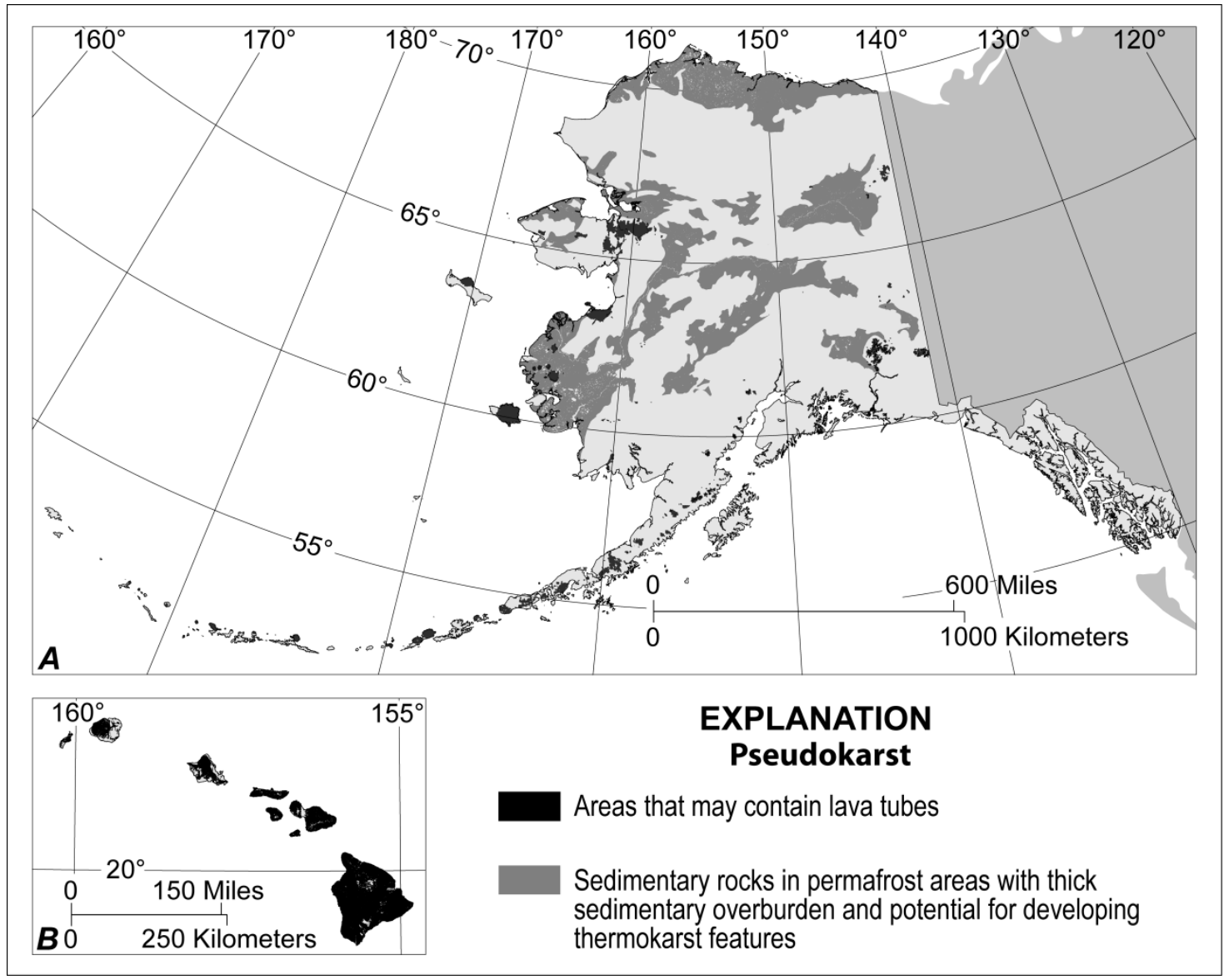

Figure 5. Simplified map of areas that may contain lava tubes or thermokarst pseudokarst features, $A$, Alaska; and $B$, Hawaii.

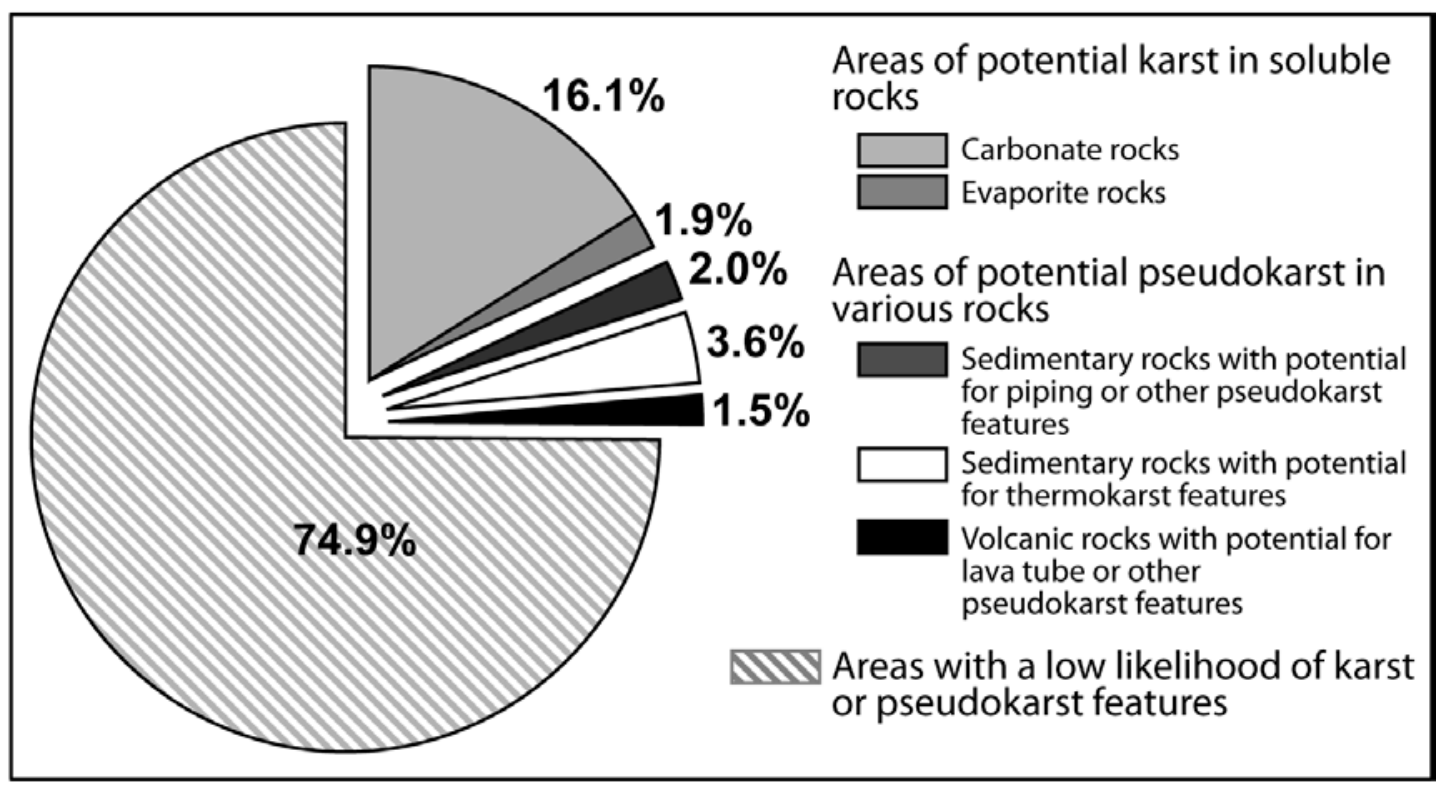

Figure 6. Chart showing proportion of the area of the 50 United States underlain by potentially karstic and pseudokarstic rocks. 


\section{REFERENCES}

Auler, A.S., and Smart, P.L., 2003, The influence of bedrock-derived acidity in the development of surface and underground karst: Evidence from the Precambrian carbonates of semi-arid northeastern Brazil: Earth Surface Processes and Landforms, v. 28, p. 157-168.

Brown, J., Ferrians, O.J., Jr., Heginbottom, J.A., and Melnikov, E.S., 2002, Circum-Arctic map of permafrost and ground-ice conditions, version 2: Boulder, Colorado USA, National Snow and Ice Data Center.

Daley, C., and Taylor, G., 2000, United States average annual precipitation, 1961-1990: Spatial Climate Analysis Service, Oregon State University, accessed 5/22/2013 at http://www.prism.oregonstate.edu/pub/prism/map s/Precipitation/Total/U.S./us.gif

Davies, W.E., Simpson, J.H., Ohlmacher, G.C., Kirk, W.S., and Newton, E.G., 1984, Engineering aspects of karst: U.S. Geological Survey, National Atlas of the United States of America, scale 1:7,500,000.

Epstein, J.B., and Johnson, K.S., 2003, The need for a national evaporite-karst map, in Johnson, K.S., and Neal, J.T., eds., Evaporite karst and engineering/environmental problems in the United States: Oklahoma Geological Survey Circular 109, p. 21-30.

Halliday, W.R., 2007, Pseudokarst in the 21st century: Journal of Cave and Karst Studies, v. 69, no. 1, p. 103-113.

Palmer, A.N., 2000, Hydrogeologic control of cave patterns, in Klimchouk, A.B., and others, eds., Speleogenesis - evolution of karst aquifers: National Speleological Society, Huntsville, Alabama, p. 77-90.

Palmer, A.N., and Palmer, M.V., eds., 2009, Caves and karst of the USA: National Speleological Society, Huntsville, Alabama, 446 p.

Shade, B.L., 2002, The genesis and hydrology of a sandstone karst in Pine County, Minnesota: Minneapolis, University of Minnesota, M.S. thesis, 131 p., 8 tables.

Soller, D.R., Packard, P.H., and Garrity, C.P., 2012, Database for U.S. Geological Survey Map I-1970 -- Map showing the thickness and character of Quaternary sediments in the glaciated United States east of the Rocky Mountains: U.S. Geological Survey Data Series 656, available at http://pubs.usgs.gov/ds/656/.
Sweeting, M.M., 1973, Karst landforms: Columbia University Press, New York, 362 p.

U.S. Environmental Protection Agency, 2013, Level III ecoregions of the conterminous United States: Office of Research and Development (ORD) National Health and Environmental Effects Research Laboratory (NHEERL), accessed $8 / 08 / 2013$ at http://www.epa.gov/wed/pages/ecoregions/level_i ii_iv.htm\#Level\%20III

U.S. Geological Survey, National Surveys and Analysis (NSA) Project, Geologic maps of U.S. states: Mineral Resources Program, U.S. Geological Survey, Reston, VA., accessed 02/010/2014, at http://mrdata.usgs.gov/geology/state/

Veni, G., 2000, Revising the karst map of the United States: Journal of Cave and Karst Studies, v. 64, p. $45-50$.

Weary, D.J., and Doctor, D.H., in press, Karst in the United States of America: A digital map compilation and database: U.S. Geological Survey Open-File Report.

Williams, P.W., and Ford, D.C., 2006, Global distribution of carbonate rocks: Zeitschrift für Geomorphologie, Supplement, v. 147, p. 1-2. 


\title{
Groundwater Availability of the Floridan Aquifer System
}

\author{
By Andrew M. O'Reilly ${ }^{1}$ and Eve L. Kuniansky ${ }^{2}$ \\ ${ }^{1}$ U.S. Geological Survey, Florida Water Science Center, 12703 Research Parkway, Orlando, FL 32826 \\ ${ }^{2}$ U.S. Geological Survey, Water Mission Area, 1770 Corporate Drive, Suite 500, Norcross, GA 30093
}

\begin{abstract}
The Floridan aquifer system is one of the most productive aquifers in the world and extends throughout 100,000 square miles of the southeastern United States in Florida and parts of Georgia, Alabama, South Carolina, and Mississippi. The Floridan aquifer system has been used since the late 1800s and currently is the primary source of water for almost 10 million people (in 2000) in parts of Florida, Georgia, Alabama, and South Carolina. Water from the Floridan aquifer system is used for public, domestic, and industrial water supply, and almost 50 percent of withdrawals are used for irrigation. Where water in the Floridan aquifer system is not potable, shallower aquifers generally are used for water supply, most notably the Biscayne aquifer, which is the sole source of fresh groundwater in southeast Florida.

The U.S. Geological Survey (USGS) Groundwater Resources Program (http://water.usgs.gov/ogw/gwrp/) is assessing groundwater availability in areas of critical importance across the Nation. The objectives of the current study on the Floridan aquifer system are to quantify current groundwater resources, evaluate possible groundwater resource changes over time, and provide tools to better understand aquifer system responses to future human and environmental stresses. This regional study of the Floridan aquifer system will provide numerous benefits, including an updated hydrogeologic framework incorporating new data available since the USGS Regional Aquifer-System Analysis study completed in the 1980s, regional and subregional water budgets, and a modern, systemwide groundwater flow model that can be used to assess the effects of human and environmental stresses on the aquifer system. Further information on the approach and current products of the study are available at $h t t p: / / f l . w a t e r . u s g s . g o v / F A S W A M /$.

The Floridan aquifer system is a sequence of carbonate rocks more than 3,000 feet (ft) thick in southern Florida, thinning to less than $200 \mathrm{ft}$ at the northern extent in southern Alabama, southeast Georgia, and southern South Carolina where it grades into clastic coastal plain sediments. A thick sequence of sand, silt, and clay confine the Floridan aquifer system over much of its extent; in these areas recharge to the aquifer system generally is less than 1 inch per year (in/yr). Where the Floridan aquifer system is thinly confined (less than $100 \mathrm{ft}$ thick), karst terrain is common, leading to semiconfined to unconfined conditions and recharge rates generally ranging from 10 to $25 \mathrm{in} / \mathrm{yr}$. The karst geologic characteristics contribute to specific aquifer vulnerabilities, including groundwater/surface-water linkage and saline-water encroachment in some areas.
\end{abstract}


Stresses on the Floridan aquifer system include land-use change and associated groundwater withdrawals, climate change, and sea-level rise; the effects of these stresses may be magnified by the vulnerabilities of the aquifer system in certain areas. For example, increased irrigation of crops in the Dougherty Plain (southwest Georgia, southeast Alabama, and adjacent areas of northern Florida) have led to streamflow and water-level decreases in the ecologically sensitive Apalachicola-Chattahoochee-Flint River Basin. Reduction or cessation of flow at some springs, sinkhole collapse and lake drainage, and reduced lake and wetland levels have occurred in central and northern Florida since the 1950s while total groundwater withdrawals from the Floridan aquifer system increased nearly fourfold. In central Florida, developed land area has increased 160 percent, and cropland/pasture has decreased 40 percent from 1977 to 2006. Such land-use changes may influence the partitioning of rainfall into evapotranspiration, runoff, and infiltration, thus affecting short-term and long-term groundwater levels and flows. Also, changing land-use practices have led to degraded water quality, particularly elevated nitrate concentrations in groundwater (wells) and springs. Saline water encroachment has occurred in localized coastal areas of South Carolina, Georgia, and northeast Florida, where groundwater movement is largely controlled by geologic features, such as paleochannels, fractures, solution-enlarged joints, or paleocollapse structures.

Climate change and sea-level rise may affect the future quantity of available groundwater in the Floridan aquifer system. Water budget analysis indicates the system is largely meteorologically driven. Water demands are likewise substantially influenced by weather owing to the prevalence of groundwater withdrawals for irrigation. Predevelopment conditions consisted of $53 \mathrm{in} / \mathrm{yr}$ of rainfall, $37 \mathrm{in} / \mathrm{yr}$ of evapotranspiration, $16 \mathrm{in} / \mathrm{yr}$ of runoff, and less than $0.5 \mathrm{in} / \mathrm{yr}$ of offshore discharge. In 2000, groundwater withdrawals totaled nearly 4 billion gallons or 0.9 in/yr, representing 2 and 6 percent of predevelopment evapotranspiration and runoff, respectively. Therefore, the Floridan aquifer system likely will be sensitive to future weather extremes and climate change, while sea-level rise may affect coastward hydraulic gradients. Even though total groundwater withdrawals are a relatively small component of the water budget, these withdrawals may be sufficient to reduce the frequency at which the system is "filled and reset," thus causing long-term declines in water levels and flows in certain areas. 


\title{
Assessing Potential Impacts from a Proposed Phosphate Mine on Ashley Spring, a Unique Karst Public Water Supply in the Uinta Mountains, Uintah County, Utah
}

\author{
By Lawrence E. Spangler \\ U.S. Geological Survey, 2329 Orton Circle, Salt Lake City, Utah 84119
}

\begin{abstract}
Ashley Spring is one of the largest springs in Utah, with a reported discharge that ranges from about 15 cubic feet per second (ft3/s) at low flow (base flow) to at least $80 \mathrm{ft} 3 / \mathrm{s}$ during the snowmelt runoff period in May and June. The spring rises from the Weber Sandstone alongside the channel of Ashley Creek in the bottom of Ashley Gorge near its outlet along the southeast flank of the Uinta Mountains. Water from the spring is a public supply for the nearby city of Vernal and residents in several rural communities in Ashley Valley, as well as for irrigation. In 2010, an estimated 3,800 acre-feet or about 3.4 million gallons per day were withdrawn from the spring for municipal use.
\end{abstract}

Previous studies of the hydrology of Ashley Spring and adjacent springs have shown a complex groundwater flow system along the southeast flank of the Uinta Mountains. Dye-tracer tests carried out primarily in the late 1960s and late 1970s indicate that most of the flow discharging from Ashley Spring originates from the Dry Fork watershed more than 10 miles to the west and also from a losing reach in Ashley Creek about 7 miles upstream of the spring. Water losses in the Dry Fork and Ashley Creek drainages occur through glacial and alluvial deposits that overlie the Madison Limestone. Fractures in the Weber Sandstone, which overlies the Madison Limestone, allow upward movement of water back to the surface at Ashley and other springs.

Proposed mining of the Park City Formation near Ashley Spring has raised concerns among county leaders and local citizens that mining may impact the quality and discharge of the spring water. Possible impacts of the mining operation on the hydrologic system include effects on the water quality of the spring by downward movement of water from the Park City Formation through the Weber Sandstone with constituents related to mining activities, such as phosphate and selected trace elements; possible effects on the water quality of the Madison Limestone aquifer, from which the spring discharges; and the effects of blasting on the groundwater flow system. This study expands upon previous studies and is conducting additional investigations to improve our understanding of the recharge (contributing) area for Ashley Spring, and the relation between groundwater movement in the Madison Limestone aquifer and the overlying Weber Sandstone, to evaluate the potential impacts of the proposed phosphate mine on the groundwater system.

\section{INTRODUCTION}

Proposed mining of the Park City (Phosphoria) Formation near Ashley Spring, about 12 miles north of Vernal, Utah, has raised concerns among county leaders and local citizens of the effects that the mining may have on the quality and discharge of the spring water. Groundwater travel times of only a few days have been documented through the Madison Limestone aquifer that supplies water to the spring (Maxwell and others, 1971), but relatively little data are available with respect to groundwater movement in the overlying units in this area, particularly the Weber Sandstone.
Although previous studies have documented the general boundaries of the Ashley Spring groundwater system to the west and northwest, additional studies are needed to further identify sources of water to the spring and better define groundwater basin boundaries between Ashley and adjacent groundwater basins, particularly the Brush Creek Spring basin to the northeast. An understanding of the directions and rates of groundwater flow in this area would allow a better assessment of the potential for the proposed mining operation to affect the groundwater system supplying Ashley Spring. Further, Uintah County is in the process of 
updating the groundwater source-protection area for Ashley Spring, and this study will provide additional information to help fulfill the recommendations outlined in the sourceprotection management plan for the spring.

To address these concerns, the U.S. Geological Survey in cooperation with Uintah County, is conducting a 3-year study that began in the spring of 2013, to evaluate the vulnerability of the Ashley Spring groundwater flow system and the potential effects of the proposed phosphate mining operation on the spring. The objectives of this study are to 1 ) refine the contributing area of the groundwater flow system for Ashley Spring and to understand its relation/connection to adjacent basins and downgradient areas along the southeast flank of the Uinta Mountains, 2) evaluate groundwater movement in the Madison Limestone aquifer and overlying geologic units in the vicinity of the spring, particularly the Weber Sandstone, and the potential for downward movement of water from the Park City Formation through the Weber Sandstone, and 3) assess the potential for blasting and other mining activities to affect the groundwater system that supplies water to Ashley Spring. This paper provides an overview of the hydrogeology along the southeast flank of the Uinta Mountains in the vicinity of Ashley Spring and discusses the multi-phased approach that will be used to fulfill the objectives outlined above.

\section{GEOLOGY AND KARST DEVELOPMENT}

The Uinta Mountains (Uintas) are part of the Middle Rocky Mountains physiographic province and are an east-west trending anticlinal structure. The range was initiated in the early Tertiary Period (Paleocene) and intermittently uplifted into the Miocene (Untermann and Untermann, 1969). Rocks making up the Uintas are Precambrian to Tertiary in age, with a distinct absence of Ordovician- and Silurian-age rocks; outcrops of Devonian-age rocks are found only on the western edge of the mountain range. Unlike most other mountain ranges that have cores of igneous and metamorphic rocks, the core of the Uintas is composed of reddish conglomeratic, quartzitic sandstones and interbedded shales of the billion-year old Uinta Mountain Group (Stokes, 1988). Late Paleozoicand Mesozoic-age rocks unconformably overlie the Uinta Mountain Group along the flanks of the uplift and generally dip away from the core in all directions. Rocks along the southeast flank of the uplift, including the Ashley Creek-Brush Creek area, generally dip about 10 to 20 degrees to the south-southeast, except in areas of faults and folds, where they can be considerably steeper (Kinney, 1955).

Superimposed on the larger Uinta Mountain Anticline are regional faults and fractures that generally trend from west to east, and from northwest to southeast (Maxwell and others, 1971). The South Flank fault between Dry Fork and Ashley Creek trends generally north 70 degrees east and forms a boundary between the quartzitic rocks of the higher Uintas and overlying Paleozoic rocks (Sprinkel, 2006). Water flowing off the quartzitic rocks and onto carbonate rocks typically loses to the subsurface within a short distance of this boundary (fig. 1). The Deep Creek fault zone between Mosby Sink and Dry Fork (not shown on figure 1) consists of a series of parallel faults that trend generally northwest at about 60 degrees (Maxwell and others, 1971). North-northwest trending fractures are also present throughout the area, often associated with localized anticlinal structures, such as those present in both the Ashley Creek and Big Brush Creek drainages. The trend of many of the major surface drainages in the southeastern part of the Uintas, as well as the location of large springs such as Ashley and Brush Creek, have been influenced by regional fault and fracture systems (Maxwell and others, 1971).

The principal carbonate and cave-forming units in the Uinta Mountains are Mississippian in age and include the Madison and Deseret Limestones, and the Humbug Formation (Sprinkel, 2006). In the study area, the Madison Limestone is the predominant unit. These formations typically consist of light to dark gray, 


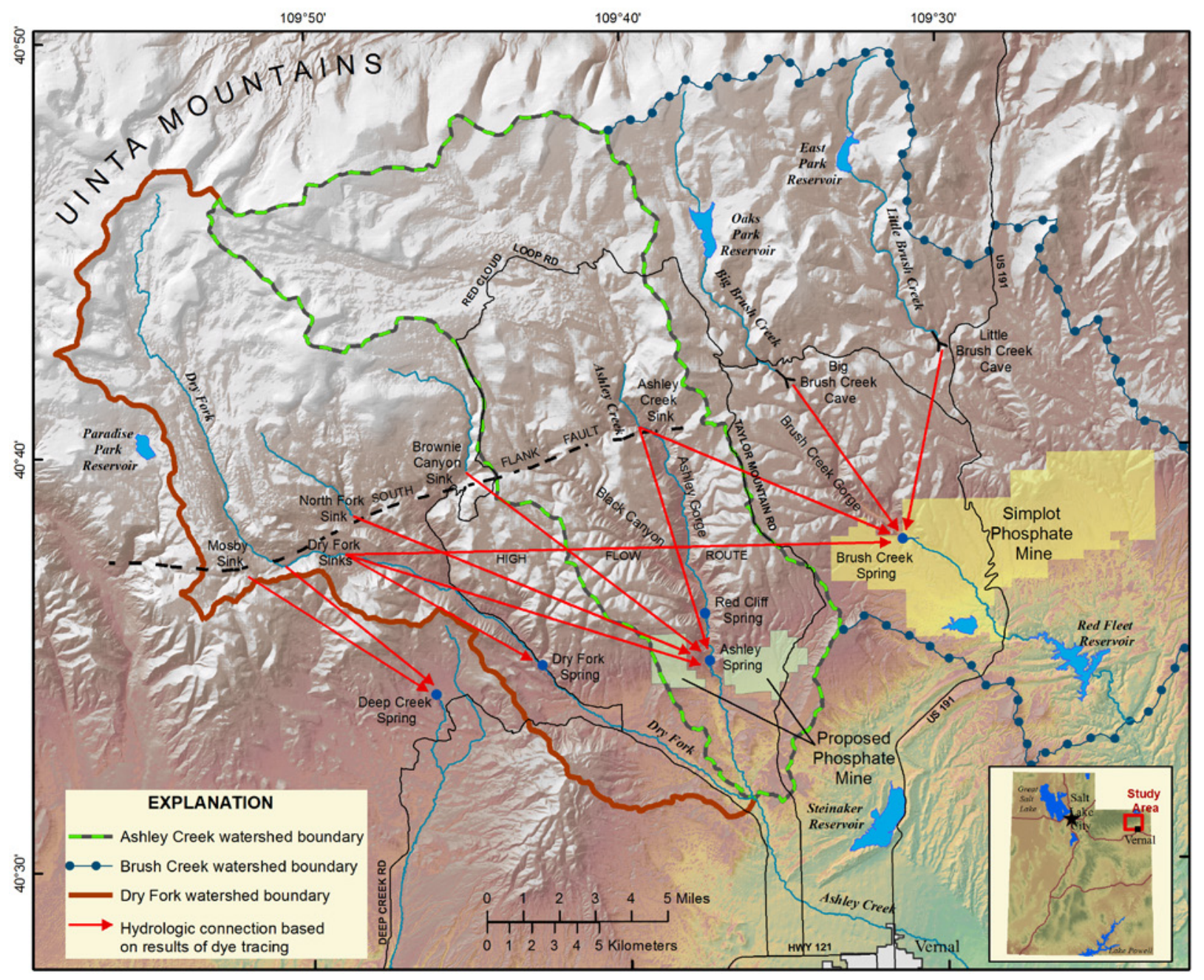

Figure 1. Location of major springs along the southeast flank of the Uinta Mountains near Vernal, Utah, results of dye tracing, and location of proposed phosphate mine.

thin- to thick-bedded, cherty (siliceous), and locally brecciated, dolomitic limestones. Average thickness of the Mississippian-age limestones is about 900 to 1,200 feet. The overlying Pennsylvanian-age Weber Sandstone is a very prominent rock unit in the eastern Uintas, forming many of the canyon walls in the major drainages, such as in Ashley Gorge and Big Brush Gorge (fig. 2). The formation ranges from about 1,000 to 1,275 feet in thickness in the study area and consists of predominantly massive, tan to white cross-bedded sandstone with minor amounts of sandy limestone (Haddox and others, 2010). Many of the large springs in the region, including Ashley and Brush Creek, discharge upward through fractures in the Weber Sandstone (fig. 3). Overlying the Weber
Sandstone in the vicinity of Ashley Spring is the Permian-age Park City Formation. The formation is quite variable in lithology and consists of light gray to brown sandy dolostone interbedded with reddish-orange siltstone and dark gray phosphatic shale (basal 20 feet) (Haddox and others, 2010). Thickness of the Park City Formation ranges from 50 to 145 feet.

Karst features are sporadically developed in the eastern Uintas, largely because of the limited exposure of carbonate rocks. Losing or sinking streams can be found in many drainages, particularly where surface streams originating on the quartzitic core of the mountains at higher elevations cross the band of limestones that flank the core, a transition zone roughly defined 


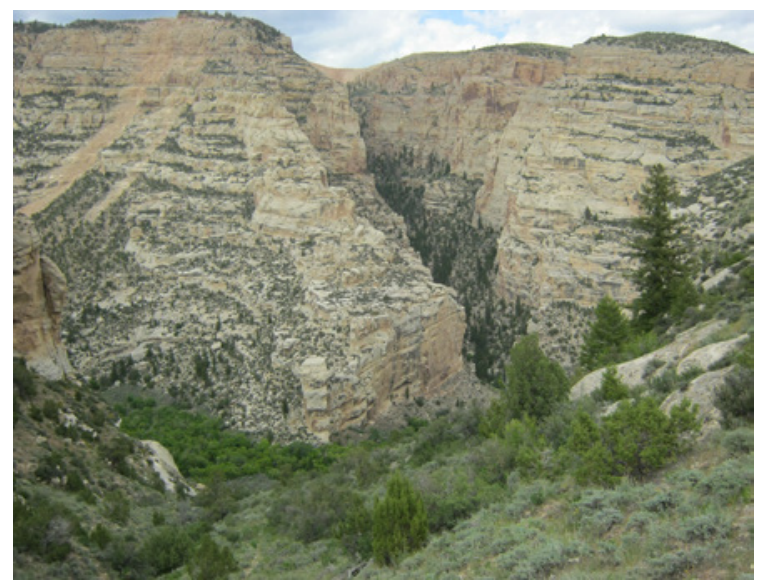

Figure 2. Outcrop of the Weber Sandstone in Big Brush Gorge. Fractures in the sandstone allow water to discharge at the surface at Brush Creek Spring, located in the bottom of the canyon at lower right.

by the South Flank fault (fig. 1). Both Big Brush Creek and Little Brush Creek Caves were formed by entrenchment of surface streams flowing off the insoluble core of the Uintas onto the soluble limestones, which has resulted in the development of blind valleys at the entrances of both caves (fig. 1). Streamsinks or "sinks" also have formed in the drainages of Dry Fork and its tributaries, and in the upper reaches of Ashley Creek (fig. 4), where they are capable of swallowing the entire streamflow except during periods of snowmelt runoff and possibly during locally intense rainfall events. In the Dry Fork drainage, glacial moraines appear to have impounded or otherwise influenced the location and development of the streamsinks (Godfrey, 1985). The largest springs in the southeastern part of the Uintas also discharge within or along the principal drainages. On the basis of average discharge, Ashley and Brush Creek Springs are considered second magnitude springs (10 to 100 cubic feet per second $\left[\mathrm{ft}^{3} / \mathrm{s}\right]$ ) (Meinzer, 1927).

\section{HYDROLOGY}

Groundwater movement along the southeast flank of the Uintas is generally to the south and southeast, following the geologic structure. Direction of movement is influenced in large part by structural dip of the rocks, regional fractures and faults, and localized breccia zones. Water generally moves down dip or along faults in the Mississippian-age limestones to lower

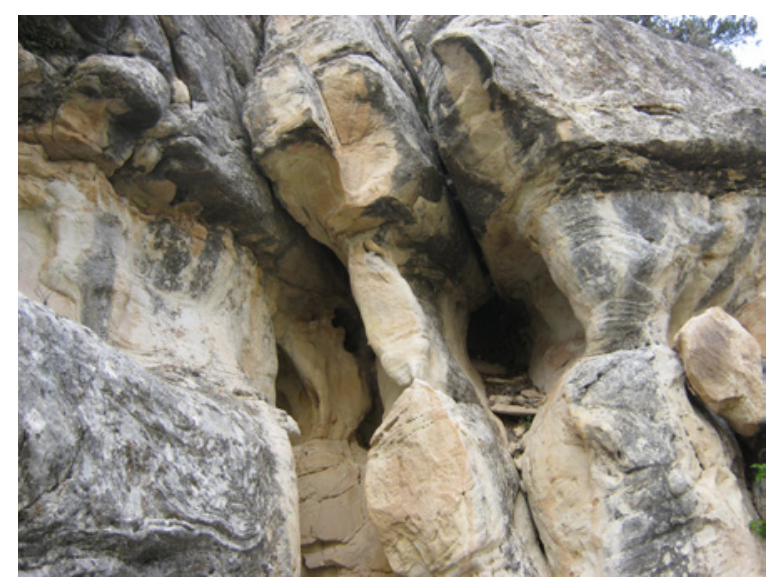

Figure 3. Near-vertical northwest-trending fractures in the Weber Sandstone. Fractures such as these likely serve as pathways for upward movement of water from the Madison Limestone to the surface at Ashley Spring.

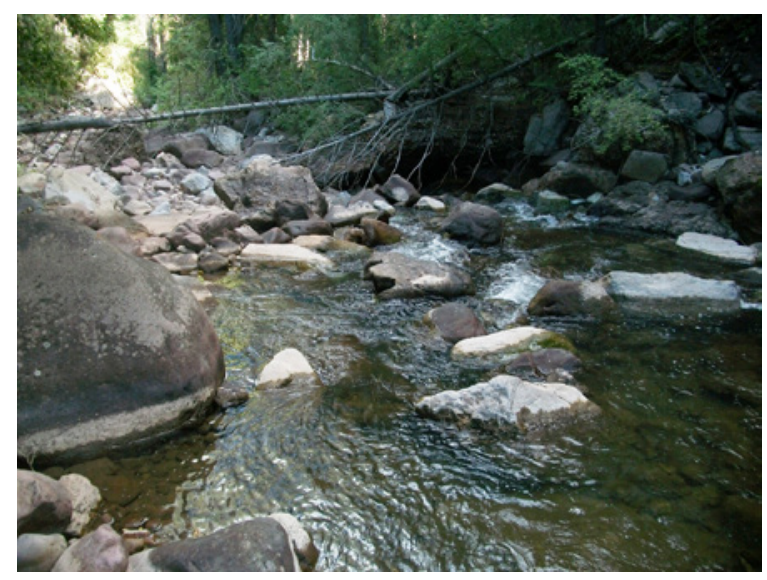

Figure 4. Ashley Creek Sink. All flow in streambed, estimated to be at least $10 \mathrm{ft}^{3} / \mathrm{s}$, abruptly sinks through boulders into the underlying Madison Limestone, which then conducts water along solution-enlarged fractures and (or) down dip along bedding planes to Ashley Spring, 7 miles to the south.

elevations where it discharges at large springs along the major drainages. Because the aquifer is generally confined (under artesian pressure) near the springs, groundwater movement is typically upward from the Madison Limestone aquifer along fractures and faults in the overlying Pennsylvanian-age rocks, particularly the Weber Sandstone. White (1979) calculated the depth to the top of the Madison Limestone in the vicinity of Ashley and Brush Creek Springs to be as much as 2,000 feet by extrapolating the structural dip of the rocks. On the basis of dyetracer tests carried out in the mid-1940s and mid-1950s, and in the late 1960s and 1970s 
(table 1), at least five major groundwater basins have been delineated along the southeast flank of the Uintas. A brief summary of the hydrology of four of these basins is as follows.

\section{Ashley Spring}

Ashley Spring rises from boulder alluvium on the east side of Ashley Creek in the bottom of Ashley Gorge near its outlet. The main spring is covered and partly diverted to two water treatment plants for drinking-water and other public-supply uses in the city of Vernal as well as several smaller communities in the region. Water not diverted for public supply is discharged from the springhouse and rejoins Ashley Creek downstream (fig. 5). Several other springs discharge directly from bedrock outlets on the west side of the channel, and subsequently flow into Ashley Creek (fig. 6). Water discharging from the west side of the channel is not used for public supply but is withdrawn from the channel farther downstream for use in irrigation. Total discharge of all springflow is reported to range from about 15 cubic feet per second $\left(\mathrm{ft}^{3} / \mathrm{s}\right)$ at base flow to about $80 \mathrm{ft}^{3} / \mathrm{s}$ following snowmelt runoff (Mundorff, 1971). Historic dye tracing (Maxwell and others, 1971) indicates that a large part of the flow discharging from Ashley Spring originates from the Dry Fork Canyon watershed, which also supplies water to Dry Fork Springs (see next section) (table 1). During periods when Dry Fork Springs do not flow, all flow from the sinks in the Main Fork of Dry Fork is assumed to discharge at Ashley Spring. Water losing in Dry Fork and its tributaries appears to move through glacial and alluvial deposits into the underlying Madison Limestone aquifer to Ashley Spring where fractures in the overlying Weber Sandstone allow upward movement of water back to the surface. These fractures are probably related to an anticlinal structure in this area, which has likely influenced the discharge point of the spring. Part of the flow path to Ashley Spring from Dry Fork may be along segments of the Deep Creek fault zone. Results of dye tracing have also shown that an additional source of water to Ashley Spring originates from a losing reach in Ashley Creek about 7 miles upstream of the spring (Godfrey, 1985).

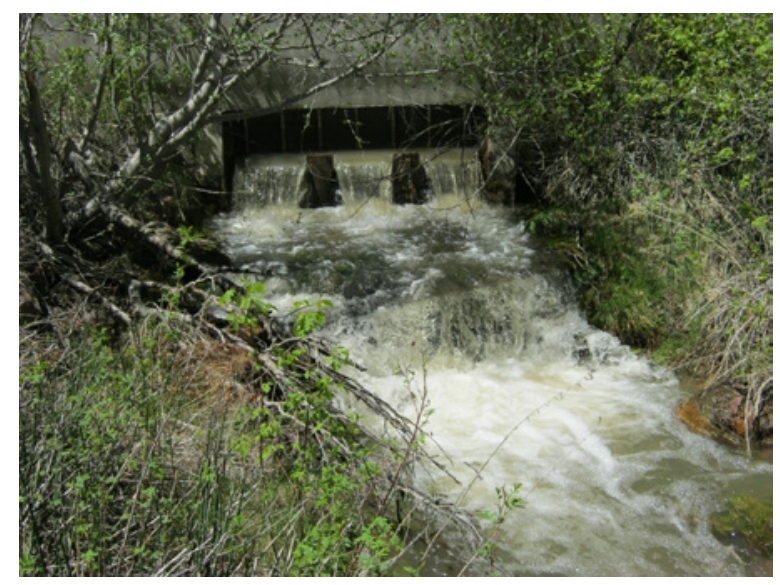

Figure 5. Overflow from Ashley Spring. Water not diverted for public supply is discharged from springhouse back into Ashley Creek.

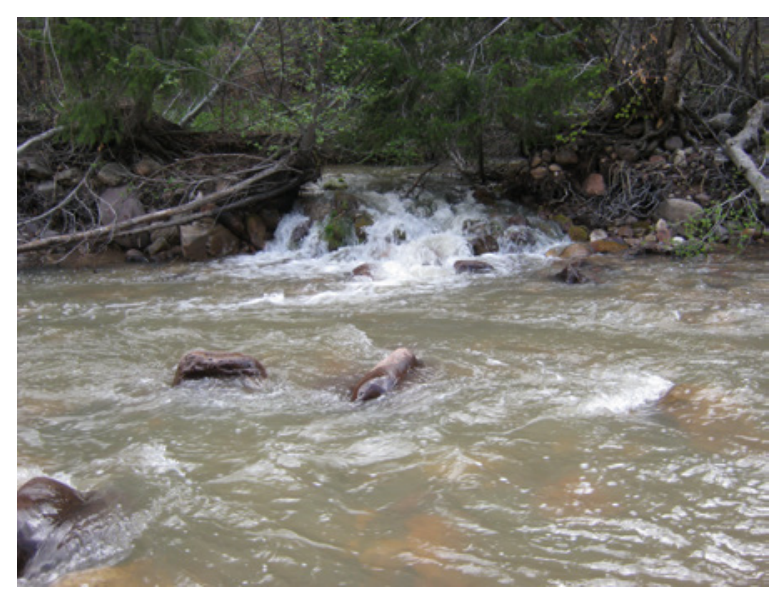

Figure 6. Ashley Spring discharges from the west and east sides of Ashley Creek (foreground). Flow from the west side (shown here) discharges from at least four major and several smaller outlets.

\section{Dry Fork Springs}

Dry Fork Springs rise in the bed of Dry Fork about 2 miles upstream of the community of Dry Fork (fig. 1). The springs discharge from the Weber Sandstone upward through alluvium at several locations in the channel. Discharge of the springs normally is zero, but during snowmelt runoff is estimated to be as much as $80 \mathrm{ft}^{3} / \mathrm{s}$ (Mundorff, 1971). Estimates of flow from current meter measurements indicate that springflow generally begins once surface flow in the three principal tributaries of Dry Fork upstream of the springs exceeds about $40 \mathrm{ft}^{3} / \mathrm{s}$ (Maxwell and others, 1971). Because water from 
Table 1. Results of dye-tracer tests for selected karst springs in the southeastern Uinta Mountains.

[BOR, Bureau of Reclamation; SCS, Soil Conservation Service; USGS, U.S. Geological Survey; USFS, U.S. Forest Service]

\begin{tabular}{|c|l|l|l|l|r|r|r|r|}
\hline $\begin{array}{c}\text { Date of } \\
\text { test }\end{array}$ & $\begin{array}{c}\text { Agency } \\
\text { conduct- } \\
\text { ing test }\end{array}$ & \multicolumn{1}{|l|}{ Input site } & $\begin{array}{c}\text { Altitude } \\
\text { (feet) }\end{array}$ & Output(s) site(s) & $\begin{array}{c}\text { Altitude } \\
\text { (feet) }\end{array}$ & $\begin{array}{c}\text { Relief } \\
\text { (feet) }\end{array}$ & $\begin{array}{c}\text { Linear } \\
\text { dis- } \\
\text { tance } \\
\text { (miles) }\end{array}$ & $\begin{array}{c}\text { Travel } \\
\text { time } \\
\text { (days) }\end{array}$ \\
\hline $6 / 1968$ & BOR, SCS & $\begin{array}{l}\text { Little Brush } \\
\text { Creek at cave }\end{array}$ & 8,100 & $\begin{array}{l}\text { Brush Creek at } \\
\text { phosphate mine }\end{array}$ & 6,120 & 1,980 & 5.6 & 2.2 \\
\hline $8 / 1967$ & BOR, SCS & $\begin{array}{l}\text { Big Brush Creek } \\
\text { above cave }\end{array}$ & 8,180 & $\begin{array}{l}\text { Brush Creek at } \\
\text { phosphate mine }\end{array}$ & 6,120 & 2,060 & 5.9 & 2.6 \\
\hline $2 / 1956$ & USGS & Mosby Sink & 9,160 & Deep Creek Spring & 7,160 & 2,000 & 6.4 & 14 \\
\hline $\begin{array}{c}\text { mid- } \\
1940 s ?\end{array}$ & BOR & Dry Fork Sinks & 8,080 & Dry Fork Springs & 6,860 & 1,220 & 6.7 & $\begin{array}{c}\text { No } \\
\text { data }\end{array}$ \\
\hline $8 / 1967$ & BOR, SCS & Dry Fork Sinks & 8,080 & $\begin{array}{l}\text { Ashley Spring } \\
\text { (Merkeley Park) }\end{array}$ & 6,260 & 1,820 & 10.5 & 2.8 \\
\hline $10 / 1967$ & BOR, SCS & $\begin{array}{l}\text { Main Dry Fork } \\
\text { (Blanchett Park) }\end{array}$ & 8,080 & $\begin{array}{l}\text { Ashley Spring } \\
\text { (Merkeley Park) }\end{array}$ & 6,260 & 1,820 & 10.5 & 3.3 \\
\hline & & & 8,080 & Deep Creek Spring & 7,160 & 920 & 46 & \\
\hline $5 / 1979$ & USFS & Dry Fork Sinks & 8,080 & Brush Creek Spring & 6,120 & 1,960 & 15.8 & 20 \\
\hline $8 / 1978$ & USFS & Ashley Creek & 7,800 & Ashley Spring & 6,260 & 1,540 & 7.0 & 14 \\
\hline & & (Red Pine) & & Brush Creek Spring & 6,120 & 1,680 & 8.1 & 9 \\
\hline
\end{tabular}

${ }^{1}$ Groundwater travel time based on first appearance of dye, whether detected in water samples or on activated charcoal.

${ }^{2}$ Dye was injected into Main Fork, North Fork, and Brownie Canyon simultaneously. Calculations based on Main Fork Sinks.

${ }^{3}$ Dye was injected upstream of Main Fork Sinks and initially traveled on surface for 8.3 miles (17 hours) before losing at sinks.

${ }^{4}$ Distance uncertain; losing reach between Mosby Sink and Dry (Main) Fork Sinks.

${ }^{5}$ Tracer test conducted during high-flow conditions.

Dry Fork Sinks and its tributaries also discharges at Ashley Spring, Dry Fork Springs may represent a high-level or overflow point within the Ashley Spring groundwater flow system. Detailed studies by Maxwell and others (1971) indicate that water losing from Dry Fork and its tributaries, between 5 and 7 miles upstream of the springs, flows through conduits in the underlying Madison Limestone aquifer and thence upward along fractures in the overlying rocks to discharge at the surface, rather than through the fluvioglacial channel deposits (sub-channel flow) to the springs. The flow system feeding Dry Fork Springs is likely developed along segments of the Deep Creek fault zone (Maxwell and others, 1971, fig. 2).

\section{Deep Creek Spring}

Deep Creek Spring rises along a hillside from the base of the Triassic-age Moenkopi Formation on the upthrown side of a northwesttrending fault (Maxwell and others, 1971).
Discharge of the spring is reported to range from 3 to $15 \mathrm{ft}^{3} / \mathrm{s}$, with higher flows during snowmelt runoff (Mundorff, 1971). Results of dye tracing indicate that water diverted into Mosby Sink, located along a tributary to the Main Fork of the Dry Fork drainage, resurges at Deep Creek Spring 6 miles southeast of the sink (fig. 1). Actual travel time of groundwater from Mosby Sink to Deep Creek Spring was about 14 days (table 1). Because water discharging from the spring is confined, however, an increase in springflow was observed in only 3 hours, in response to a pressure wave generated by the diverted water. Some of the base flow of Deep Creek Spring also appears to originate directly from the Main Fork of Dry Fork (fig.1). Groundwater flow from Mosby Sink and Dry Fork to Deep Creek Spring is probably along northwest-trending faults that are associated with the Deep Creek fault zone. These faults also serve as pathways for upward movement of water from the underlying Madison aquifer. 


\section{Brush Creek Spring}

Brush Creek Spring rises in the bottom of Big Brush Gorge near its outlet. The spring discharges from the lower part of the Weber Sandstone where localized fracturing along the axis of an anticline has permitted upward movement of water from the underlying Madison Limestone aquifer back to the surface. Groundwater movement to Brush Creek Spring is likely down the structural dip of the Madison Limestone to the spring. Estimated discharge of Brush Creek Spring ranges from 3 to about 200 $\mathrm{ft}^{3} / \mathrm{s}$ (Mundorff, 1971), making this one of the largest springs in Utah. Results of dye tracing during the summers of 1967 (Big Brush Creek) and 1968 (Little Brush Creek) indicate that much of the water discharging from the spring originates from both of these creeks via Big and Little Brush Creek Caves (fig. 1, table 1). These dye tests confirmed previous indications of this relation when reservoir releases upstream of Little Brush Creek Cave resulted in substantial increases in the discharge of Brush Creek Spring (Maxwell and others, 1971). Dye travel time from Big Brush Creek at the Red Cloud Loop Road above the entrance to Big Brush Creek Cave, to Highway 191 where it crosses over Brush Creek, about 3.5 miles downstream from the spring, was about 63 hours. Dye travel time from Little Brush Creek Cave to Brush Creek at Highway 191 was about 52 hours. Although the majority of flow from Brush Creek Spring appears to originate from the Brush Creek drainage basin, additional dye tracing also has indicated apparent hydrologic connections between Dry Fork Sinks (at high flow) and Brush Creek Spring, and Ashley Creek Sink and Brush Creek Spring (Godfrey, 1985) (fig. 1).

\section{DISCUSSION}

During the 3-year study beginning in April 2013, a multi-phased approach will be used to further our understanding of the hydrology of Ashley Spring and the hydrology of overlying geologic units in the vicinity of the spring. The approach includes dye tracing, water sample collection and analysis, discharge measurements, water-level measurements, and analysis of seismic data.
Fluorescent dye tracing will be used to establish hydrologic connections between focused points of recharge (surface-water inputs) and Ashley Spring, particularly in areas where data are sparse with regard to groundwater movement, and also will be used to determine better estimates of groundwater travel time. If possible, tracer tests also will be used to refine the boundary between groundwater movement to Ashley and Brush Creek Springs. A dye-tracer study was carried out in September 2013 to verify a previous tracer test that was done indicating a hydrologic connection between Ashley Creek Sink and Ashley and Brush Creek Springs (fig. 1, table 1). Results of this test are currently being evaluated.

Ten water samples were collected from selected springs and wells in bedrock aquifers in the study area in 2013 and analyzed for major ions, nutrients, and a suite of trace elements that are often associated with phosphate mining in other areas. These include aluminum, barium, strontium, arsenic, selenium, uranium, cadmium, chromium, lead, copper, nickel, and zinc. Water samples also will be collected from Ashley Spring during base flow, moderate flow, and spring (peak) runoff, and analyzed for major ions and trace elements to establish baseline conditions for the natural system prior to potential mining. Nitrate, orthophosphate, and phosphorus samples will be analyzed to determine background (native) concentrations for comparison with natural concentrations of these constituents in the Park City Formation, the lower part from which phosphate ore would be mined. Historic chemical data for Ashley Spring will be examined to evaluate trends or variations in water quality over time. In addition, water-quality data will be compiled and water samples collected from other springs and wells in the Weber Sandstone, Park City Formation, and other potential water-bearing units in the vicinity of Ashley Spring and analyzed for the same suite of constituents to characterize groundwater in these formations. The chemistry of groundwater from these units will then be compared to the water chemistry of the Madison Limestone aquifer. Samples for selected isotope analyses may be collected to further assist in determining source areas for water discharging 
from Ashley Spring (deuterium/oxygen-18) and for possible dating of the groundwater in the Madison Limestone, Weber Sandstone, and other aquifers in the study area (tritium/helium, sulfur-35, and chlorofluorocarbons).

Preliminary data indicate that dissolvedsolids concentrations in water from Ashley and Brush Creek Springs (Madison Limestone aquifer) during base-flow conditions is low (less than 150 milligrams per liter [mg/L]) compared to water from the overlying Weber Sandstone and other bedrock units in the area, which tends to be noticeably higher (greater than $200 \mathrm{mg} / \mathrm{L}$ ). The source waters for these springs, which originate on the quartzitic core of the mountain range, can be very low in dissolved solids (less than $50 \mathrm{mg} / \mathrm{L}$ ). Concentrations of trace elements and nutrients from these springs were also very low during base-flow conditions and below state drinking-water standards. In addition, continuous (1- and 2-hour intervals) measurements of temperature and specific conductance have been made at Ashley and Brush Creek Springs since April and November 2013, respectively, to document changes in these parameters with changes in discharge and to further assess groundwater travel times to the springs in response to precipitation events. Between May 2013 and March 2014, specific conductance and temperature of water from Ashley Spring was quite variable, and ranged from 94 microSiemens per centimeter $(\mu \mathrm{S} / \mathrm{cm})$ at $25{ }^{\circ} \mathrm{C}$ to $168 \mu \mathrm{S} / \mathrm{cm}$, while temperature ranged from about 6.8 to $8.7^{\circ} \mathrm{C}$.

Discharge measurements of Ashley Spring will be used to evaluate response of the groundwater system to surface events such as snowmelt runoff and rainfall and to help with determining the potential size of the drainage basin needed to supply the discharge of the spring. Because of the numerous outlets and diversions for Ashley Spring, an accurate discharge measurement of the spring had not been determined previously. Therefore, a streamflow gage was installed for the study on Ashley Creek upstream of Ashley Spring and its outlets on the west side of the channel.

Downstream of the outflow from Ashley Spring, a long-term streamflow gage records discharge that can be used in conjunction with the upstream gage to determine only the flow from Ashley Spring, in addition to withdrawals for public supply. A continuous record of discharge from the spring over the study period will also establish a baseline to which future changes in flow from natural and human-induced activities can be compared.

Water levels in all bedrock aquifers in the vicinity of Ashley Spring will be measured during the spring and fall to assess the magnitude of water-level changes and for evaluating hydraulic-head relations between the aquifers. In particular, water-level data will be collected from wells completed in the Weber Sandstone aquifer and compared to water levels in the underlying Madison Limestone aquifer to determine hydraulic-head relations (differences in water levels) between the units. These data would help to assess the potential for vertical movement of water between the formations, especially in the confined portions of the aquifers. An evaluation of the potential for downward movement of water from the Park City Formation into and through the Weber Sandstone, and thus, the ability for selected constituents from phosphate mining to move downward into the discharge zone of the spring within the Weber Sandstone or the underlying Madison Limestone also will be done. As part of this assessment, data on fracture trends and fracture density will be compiled for the Weber Sandstone to evaluate potential pathways along which downward moving groundwater could occur.

Finally, water-quality and hydrologic data from the adjacent Brush Creek Spring basin will be compiled for comparison to that from the Ashley Spring basin. The geologic and hydrologic setting of Brush Creek Spring is very similar to that of Ashley Spring, and the location of Brush Creek Spring in proximity to the Simplot phosphate mining operation about 6 miles northeast of Ashley Spring (fig. 1), could provide a useful comparison (analog) with regard to the hydrologic relation between the Madison Limestone and the overlying Weber Sandstone in this area. This relation could also allow a better assessment of the potential for 
downward movement of water from the Park City Formation through the Weber Sandstone and thus, the potential for the proposed mine to affect water quality in the area near Ashley Spring. In addition, to evaluate the potential effects of blasting on the hydrologic system supplying Ashley Spring, records from seismograph stations located near the Simplot phosphate mine along with blasting records from the mine, will be compared to discharge records and continuous water-quality data for Brush Creek Spring. Identifying changes or fluctuations in these parameters with minerelated activities could then be used to evaluate the potential for mining-induced disturbances at the proposed mine site to affect the hydrologic system within the Madison Limestone or the fracture network within the Weber Sandstone at Ashley Spring.

\section{REFERENCES}

Godfrey, A.E., 1985, Karst hydrology of the south slope of the Uinta Mountains, Utah, in Picard, M.D., ed., Geology and energy resources, Uinta Basin of Utah: Utah Geological Association Publication 12, p. 277-293.

Haddox, D.A., Kowallis, B.J., and Sprinkel, D.A., 2010, Geologic map of the Steinaker Reservoir quadrangle, Uintah County, Utah: Utah Geological Survey Miscellaneous Publication 103, 2 pl.

Kinney, D.M., 1955, Geology of the Uinta RiverBrush Creek area, Duchesne and Uintah Counties, Utah: U.S. Geological Survey Bulletin 1007, 185 p., 6 pl.

Maxwell, J.D., Bridges, B.L., Barker, D.A., and Moore, L.G., 1971, Hydrogeology of the eastern portion of the south slopes of the Uinta Mountains, Utah: Utah Department of Natural Resources Information Bulletin 21, 54 p.

Meinzer, O.E., 1927, Large springs in the United States: U.S. Geological Survey Water-Supply Paper 557, 94 p.

Mundorff, J.C., 1971, Nonthermal springs of Utah: Utah Geological and Mineralogical Survey, Water-Resources Bulletin 16, 70 p.
Sprinkel, D.A., 2006, Interim geologic map of the Dutch John 30' x 60' quadrangle, Daggett and Uintah Counties, Utah, Moffat County, Colorado, and Sweetwater County, Wyoming: Utah Geological Survey Open-File Report 491 DM, 3 pl.

Stokes, W.L., 1988, Geology of Utah: Utah Museum of Natural History Occasional Paper No. 6, 307 p.

White, W.B., 1979, Karst landforms in the Wasatch and Uinta Mountains, Utah, in Alpine karst symposium: National Speleological Society Bulletin, v. 41, no. 3, p. 80-88.

Untermann, G.E., and Untermann, B.R., 1969, Geology of the Uinta Mountain area, UtahColorado, in Lindsay, J.B., ed., Geologic guidebook of the Uinta Mountains-Utah's maverick range: Intermountain Association of Geologists and Utah Geological Society $16^{\text {th }}$ Annual Field Conference, p. 79-86. 


\title{
TRACERS
}

\section{Groundwater Tracing in Arid Karst Aquifers: Concepts and Considerations}

\author{
By George Veni \\ National Cave and Karst Research Institute, 400-1 Cascades Avenue, Carlsbad, New Mexico 88220
}

\begin{abstract}
Few groundwater tracing studies have been conducted in karst aquifers located in arid landscapes. This paper conceptually evaluates the effects of arid conditions on the injection and detection of tracers, and the interpretation of the results. Tracer injection is primarily challenged by the absence of a constant source of flowing water to flush the tracer into and through the aquifer. Artificial recharge is often needed, with the amounts best determined by examining typical conduit volume, flow, and morphological conditions of caves in the area. The tracer mass should be calculated based not only on the volume of discharge from the target spring or well, but also on the volume of discharge in the conduit into which the tracer is injected. Tracer detection is challenged mostly by the paucity of monitoring sites and factors that may compromise tracer detection, such as alluviation of springs and adsorption/filtration of the tracer, and the potentially very slow flow velocities in these aquifers. Interpretation of the results is challenged by distinguishing hydrologic behavior resulting from low hydraulic gradients/velocities, and ponded and perched conditions, from inherently different conditions in arid karst such as poorly developed vadose permeability and sedimentation within the conduit system.
\end{abstract}

\section{INTRODUCTION}

By the time the Karst Interest Group holds its 2014 workshop at the Headquarters of the National Cave and Karst Research Institute (NCKRI), construction should be underway or soon-to-begin on NCKRI's lab. Adjoining, but distinctly separate from the lab, will be a room specially designed to store dyes for groundwater tracing. While those of us at NCKRI look forward to starting a tracer program to study a variety of karst aquifers, our location in Carlsbad, New Mexico, also opens another research opportunity.

Few tracer studies have been conducted in arid karst regions. This raises some important questions that this paper conceptually discusses as three major categories: consideration for tracer injection and detection, and the implications on hydrological interpretation of the results. This paper does not distinguish between fluorescent dyes, which are most commonly used in karst groundwater tracing, and other tracers, although dye traces are often used as examples. NCKRI plans on conducting tracer studies in all climatic settings, but its home base in an arid karst landscape will provide ample opportunity to test the methods and concepts presented below.

\section{CONSIDERATIONS FOR TRACER INJECTION}

Tracer studies were developed in humid climates where many streams sink perennially into karst landscapes. Pouring some substance into the water as it disappeared underground was an intuitive and easy action to find where the flow reappeared, especially when many springs were also present.

In arid karst, springs are few and perennial sinking streams are rare to non-existent. The absence of a constant source of water that is assured to carry the tracer to the water table and through the aquifer significantly complicates tracing efforts. Two main factors must be considered when injecting tracers in such regions: tracer mass and water volume.

Worthington and Smart (2003) examined the results of 185 dye-tracing tests in carbonate aquifers. They derived the following empirical regression equations for calculating the mass of dye needed and the peak recovery concentrations: 


$$
\begin{aligned}
& \mathrm{m}=0.73(\mathrm{tQc})^{0.97} \\
& \mathrm{~m}=19(\mathrm{LQc})^{0.95}
\end{aligned}
$$

where:

$m$ is the mass of dye injected, in grams,

$t$ is the time elapsed between injection and peak recovery in seconds,

$Q$ is the output discharge, in cubic meters per second $\left(\mathrm{m}^{3} / \mathrm{s}\right)$,

$c$ is the peak recovery dye concentration for optimum detection, in grams per cubic meter $\left(\mathrm{g} / \mathrm{m}^{3}\right)$, and

$L$ is the distance in meters between injection and recovery points.

Equation 1 is used where $t$ is known, such as from previous tracer tests, and Equation 2 is used when a particular flow route is traced for the first time.

Numerous subsequent studies have shown these equations work effectively, but they were not derived from data primarily collected in arid karst aquifers and have been rarely tested in such conditions. Inherent in the equations is the fact that groundwater conduits in karst aquifers are parts of tributary systems and tracers will be diluted by inflows from other conduits. However, in arid karst aquifers, $Q$ needs to be considered as a percentage of the volume of flow in the conduit where the tracer was injected $\left(Q_{i n}\right)$. If $Q=Q_{i n}$, or is similar in volume, there is little or no dilution of the tracer. This may result in the discoloration of water supplies and higher costs in materials for no additional benefit. While this problem is conceptually easy to state, in many cases $Q_{\text {in }}$ will not be observable and may need to be estimated based on tracing experience in the aquifer and from other data, which often may not exist.

Human population in a region generally correlates to the amount of precipitation. While there are concentrated population centers in arid climates, regional populations are usually sparse and so too are groundwater data and monitoring wells and springs. Consequently, water table maps and aquifer models, if even available, are based on relatively few data points and thus, have lower precision compared to maps and models of aquifers where data and monitoring locations are abundant.

The second major factor for tracer injections in arid conditions is water volume, both for injection and within the aquifer. Without a constant source of water flowing into the aquifer from the surface, two methods are available to deliver the tracer to the water table. The first is to place the tracer into the recharge feature and wait for rain. While such a strategy can be effective for qualitative tracing, quantitative tracing is impossible and even accurate groundwater velocities cannot be assured if multiple storms occur before the tracer is detected.

The second water delivery method involves artificially injecting water into a recharge feature or well. If the injection site is near a spigot or fire hydrant, a constant source of water can flush the tracer until it is detected. If no constant water source is available nearby, water tankers can be used to flush the tracer if the terrain allows. For either method to be effective, the morphology and hydrology of caves in the area should be evaluated to estimate the likely volume of water necessary to wash the tracer into the aquifer. That volume should be at least tripled, depending on the level of confidence in the estimate and the depth to the water table. Additionally, a minimum of two estimated volumes should be injected as a pre-flush, to saturate the pores in cave sediments and maximize the speed and volume of tracer transmission to the aquifer. These methods have proven effective in karst aquifers in semi-arid climates (e.g., Johnson and others, 2010).

The volume of water within the aquifer must also be considered when injecting a tracer-not total groundwater storage but the volume within the flow path being traced. In karst aquifers, tracers are not dispersed throughout a substantial section of the aquifer, but through the far more limited volume of the conduits between the injection site and where the tracer is likely to discharge. The most effective means of evaluating that volume is by studying the aquifer's springs. 
White (1988), for example, describes how aquifer and conduit storage may be determined from spring hydrographs. In the most simplistic sense, a non-flowing spring indicates that a tracer will not be detected until groundwater levels rise and springflow resumes; artificial recharge is unlikely to result in spring discharge in most cases. If springflow is seasonal or episodic, springflow should be monitored and aquifer behavior quantified prior to conducting a tracer test to better plan the study and predict the likely tracer dilution (for calculating the tracer mass for injection) and time until tracer detection. Without such monitoring, there is a much greater chance that the tracer will be missed by not waiting long enough to detect it.

\section{CONSIDERATIONS FOR TRACER DETECTION}

Too often tracer novices have concluded that a trace “didn't work" when in fact they didn't look in the right place for the tracer and/or didn't wait long enough for the tracer to arrive. These factors are especially problematic in arid karst aquifers.

Tracing in humid climates often poses the challenge of selecting which, of an abundance of springs, are most important to monitor within the time, cost, and logistical constraints of the study. The challenge in arid climates is finding any spring to monitor. Not only are springs fewer due to less water, be it by natural causes or exacerbated by groundwater pumping, but the dry climate promotes sedimentation of stream channels where springs are most likely to occur. Alluviated springs are common, but with comparatively little hydraulic head, fewer distinctly identifiable springs form in thick alluvium. Many provide underflow through sediments beneath valley floors, which may emerge as surface flow kilometers from the buried spring outlets. The flow of many other springs never rises in ways that can be connected to the individual springs, and the presence of some is only vaguely reflected by areas of more lush vegetation in the dry landscape.

Some arid springs are poorly known and unidentified in hydrogeologic surveys because they flow short distances before the water evaporates or sinks into the stream channel. The easy availability of aerial photos through Google Earth now makes it simpler to find such locations for monitoring.

Where individual springs cannot be identified, tracer detectors can be placed at regular intervals along flowing streams. If no tracer is recovered, repeating the trace by injecting a greater tracer mass may be warranted if the springs emerge below thick alluvial deposits that could adsorb or otherwise filter the tracer.

The discrete conduit flow paths in karst aquifers often make it impractical to trace to wells, but in arid karst aquifers where few springs are available for monitoring, wells should be considered important parts of the tracer detection program whenever possible. If all wells within the likely flow paths cannot be monitored, wells with indications of intersecting groundwater conduits should be selected (e.g., bit drops, rapid changes in water levels, turbid flows, large volume discharge, etc.). By intersecting high-permeability conduits, these wells monitor groundwater that has converged from broader areas, increasing the likelihood of tracer detection.

Perhaps the greatest challenge and uncertainty in tracing arid karst groundwater is determining how long to wait for a tracer to appear. Tracing experience in the area is helpful but there is probably more variability in arid karst than in humid karst to offer reliable predictability. Hydrograph and other directly related hydrogeologic data should be collected and interpreted in advance whenever possible to estimate the probable time frame of tracer arrival. It is important that such estimates be based on karstic, not Darcian flow conditions. As indicated previously, conduit storage is an important consideration but so are antecedent conditions, lag time between recharge events and spring response, and the degree of spring response to variable precipitation rates and volumes. 


\section{IMPLICATIONS FOR HYDROLOGICAL INTERPRETATION}

Once a tracer has been detected at a well or spring, what does it mean about the hydrology of the aquifer? In general, groundwater velocities are slower in arid climates due to less hydraulic head, but is that the sole consideration?

Jim Nepstad and Paul Burger (personal communication, 2014) respectively conducted tracer tests from above Wind Cave, South Dakota, in 1993-1996, and Carlsbad Cavern, New Mexico, in 2005. Mean rainfall in those areas is 44 and $33 \mathrm{~cm} /$ year, respectively. Both traces exhibited mostly slow and variable groundwater velocities and long storage times. Dye appeared in Wind Cave in as little as 1 day to as long as 5 years. Dye in Carlsbad Cavern first appeared in 21-40 days and persisted for at least 1.5 years. These slow velocities, at least when compared to many karst aquifers, is at least partly the result of poor saturation of vadose zone fractures. However, other factors must also be considered.

Both Wind Cave and Carlsbad Cavern are hypogenic caves formed independently of immediately overlying recharge features. While overprinting of vadose, epigenic morphologies occurs in many hypogene caves (for examples, see Klimchouk, 2007), the semi-arid climate at these caves has minimized their development. Hypogene factors aside, are arid karst aquifers recharged at a quantifiably lower rate due to less water and carbon dioxide (from less vegetation) available to enhance vadose permeability? Additional future tracer studies may help answer this question.

Goodbar (2009) also reported apparently slow groundwater velocities in the Carlsbad area but within the phreatic zone. Do phreatic conditions in arid climates fundamentally affect aquifer hydrology? Surface streams in arid regions form anastamosed and braided patterns. Related patterns occur in bedrock conduits of caves due to flooding, where groundwater is injected into bedding planes and fractures, where it is stored and dissolves a multitude of conduits until the floodwaters drain away. Could similar patterns significantly form in caves by lowgradient to ponded water? The water chemistry would be less aggressive in dissolving the bedrock, which could potentially be overcome with sufficient time, but it is not currently suggested by maps and observations of most arid climate caves beyond typical storage and flow from fractures and bedding planes that surround cave passages.

Alternatively, sediment deposition in lowgradient conditions could create other restrictions to groundwater flow. Travel times could be reduced and, as with alluviated surface streams, large volumes of saturated sediment could adsorb or filter tracers to reduce their detectability.

Perched and pooled groundwater in conduits is potentially more common in arid versus humid karst, which will affect tracer detection. Intermittent appearance of a tracer may reflect intermittent flushing of a tracer out of a pool or perched zone by multiple recharge events. It could also result from a single recharge event converging at and flushing the tracer from the pool or perched zone at different times. Residual tracer that is trapped within a pool or in perched groundwater may reappear during subsequent trace studies and result in misleading data and faulty conclusions if its source is not correctly recognized.

Where groundwater is shallow, roots from trees occasionally extend into conduits and withdraw water. Groundwater is not subject to evaporation, but potentially substantial transpirational losses may occur. Calculations of conduit groundwater storage from tracer and hydrograph data may show exceptional variability and inaccuracy as a result of such losses.

Anthropogenic factors must also be considered in arid regions, more so than in humid climates. Groundwater mining (unsustainable groundwater withdrawals) is more common in arid regions where pumping water wells have a proportionally greater impact on aquifer hydrology. As a result, the influence of wells on groundwater movement should increasingly be considered in planning tracer tests at potential major detection sites and in interpreting the time, direction, and volume of flow. 


\section{CONCLUSIONS}

Tracer studies in arid karst aquifers pose a variety of challenges and uncertainties not found in humid climates. This paper presents some of these factors, which are present throughout all aspects of a tracer study: injection, detection, and interpretation. Presently, relatively few tracer investigations have occurred in arid karst areas, but future research will refine the observations of this paper, answer its questions, and probably provide hydrogeological insights not currently considered.

\section{REFERENCES}

Goodbar, J.R., 2009, Dye tracing oil and gas drilling fluid migration through karst terrain: A pilot study to determine potential impacts to critical groundwater supplies in southeast New Mexico, USA, in White, W.B., ed.: Proceedings of the $15^{\text {th }}$ International Congress of Speleology, p. 15071510.

Johnson, Steve, Schindel, Geary, and Veni, George, 2010, Tracing groundwater flowpaths in the Edwards aquifer recharge zone, Panther Springs Creek Basin, northern Bexar County, Texas: Edwards Aquifer Authority Report No. 10-01: 112.

Klimchouk, Alexander, 2007, Hypogene speleogenesis: Hydrogeological and morphogenetic perspective: National Cave and Karst Research Institute Special Paper No. 1, 106 p.

White, W.B., 1988, Geomorphology and hydrology of karst terrains: New York, Oxford University Press, $464 \mathrm{p}$.

Worthington, S.R.H., and Smart, C.C., 2003, Empirical determination of tracer mass for sink to spring tests in karst, in Beck, B.F., ed., Sinkholes and the engineering and environmental impacts of karst, Proceedings of the ninth multidisciplinary conference: American Society of Civil Engineers, Geotechnical Special Publication, No. 122, p. 287-295. 


\title{
Challenges to a Karst Dye-Tracing Investigation in an Urban Brownfields Area, Springfield, Missouri
}

\author{
By Douglas R. Gouzie ${ }^{1}$, Kevin L. Mickus ${ }^{1}$, and Micah V. Mayle ${ }^{1}$ \\ ${ }^{1}$ Department of Geography, Geology, and Planning, Missouri State University, 901 S. National Ave., \\ Springfield, MO 65897
}

\begin{abstract}
Urban karst areas seldom lend themselves well to traditional karst investigation methods such as dye tracing. Often the impetus for an urban karst investigation is the detection of chemicals at a specific location, such as a spring, leading landowners or regulators to seek for the source area feeding that spring. If historic dye traces have not been done or recorded and disseminated in an accessible database, new studies may be hampered by limited access to obvious surficial karst features such as sinkholes and springs, many of which may have been covered over with engineering projects. Dye tracing may also be impacted by urban stormwater management, which may direct excess water into tracing routes and thus interfere with estimates of appropriate dye-injection amounts. Other tools more recently added to the karst toolbox, such as shallow geophysics, may also be hampered by urban infrastructure, such as electrical interference from utility lines.
\end{abstract}

A recent investigation to determine the source of water to a hydrocarbon-contaminated spring uncovered during Brownfields remediation activities at an urban karst site in Springfield, Missouri, encountered numerous practical problems. A combination of dye-tracing and shallow geophysical methods was used to determine possible subsurface flow paths contributing flow to the spring. Urban issues posed challenges for the project, including high-discharge stormflows related to urban pavement runoff, limited dye input locations due to urban cover and past landscape alteration, timeline pressures of a remedial project, and contaminant interference with dye detection. The issues encountered and efforts to address those issues and arrive at a successful end result of the karst investigation are presented.

\section{INTRODUCTION}

Traditional karst investigations often involve the study of water movement in a region underlain by carbonate rocks. Such studies may include drainage basin delineation, specific recharge/discharge areas, groundwater flow paths and velocities, or similar issues (Luhmann and others, 2012). Often these studies have no specific timetable and only follow the workload of the investigators and the climate conditions at the site (Brahana, 2011). Investigations in urban karst areas tend to have similar strategies, although there are some notable differences. For example, in urban areas, surface karst features such as sinkholes, may have been covered over by buildings or infrastructure. Equally troubling, disruption to the routines of local citizens may impose shortened timelines for investigations than are typically experienced in regional studies. In addition, issues such as industrial pollution tend to be more common in urban areas. This report discusses an investigation attempting to determine the source of hydrocarbon contamination to a spring discovered during remediation of an urban Brownfields site.

\section{Site Background}

The study site is an urban Brownfields project in the city of Springfield, Missouri. Springfield is located in the Ozarks Plateaus physiographic region. The study area consists of an east-west-trending valley containing a channelized urban stream, Jordan Creek. Jordan Creek flows roughly east to west for approximately 4 miles through the central business district of Springfield before emptying into Wilsons Creek, a major stream running southward along the western edge of the city.

The study area, shown in figure 1 , was primarily occupied for many years by the Springfield railway station and multiple railyard sidings, freight docks, and rail maintenance facilities. In the mid $20^{\text {th }}$ century, the main railyard operations moved farther north toward the edge of the city, and the site area reverted to 
mostly abandoned or under-used buildings and rail sidings. The Brownfields Program is a means by which the U.S. Environmental Protection Agency (EPA) can accelerate the typical superfund remedial process in order to facilitate urban renewal and development.

\section{Geologic Setting}

Springfield has a four-season climate with warm, humid summers and winter temperatures cold enough for snow. Average annual precipitation is 45 inches spread across the year (Springfield Business Development Corp, 2013).
The geologic setting of Springfield is dominated by nearly flat-lying carbonate rocks with dips of 0 to 2 degrees. The surficial unit across the entire project area is the Mississippian-age Burlington-Keokuk Limestone, which is in excess of 200-feet thick in most of the Springfield area. The Burlington and a few thinner underlying carbonate units (Pierson, Elsey, and Reeds Spring Formations) compose the Springfield Plateau aquifer. Underlying these units, the Northview Formation is a shaly unit that acts as a leaky confining layer overlying the Ozark aquifer (Imes and Emmett, 1994). The Ozark aquifer includes greater than 1,000 feet of Ordovicianage dolostones and limestones.

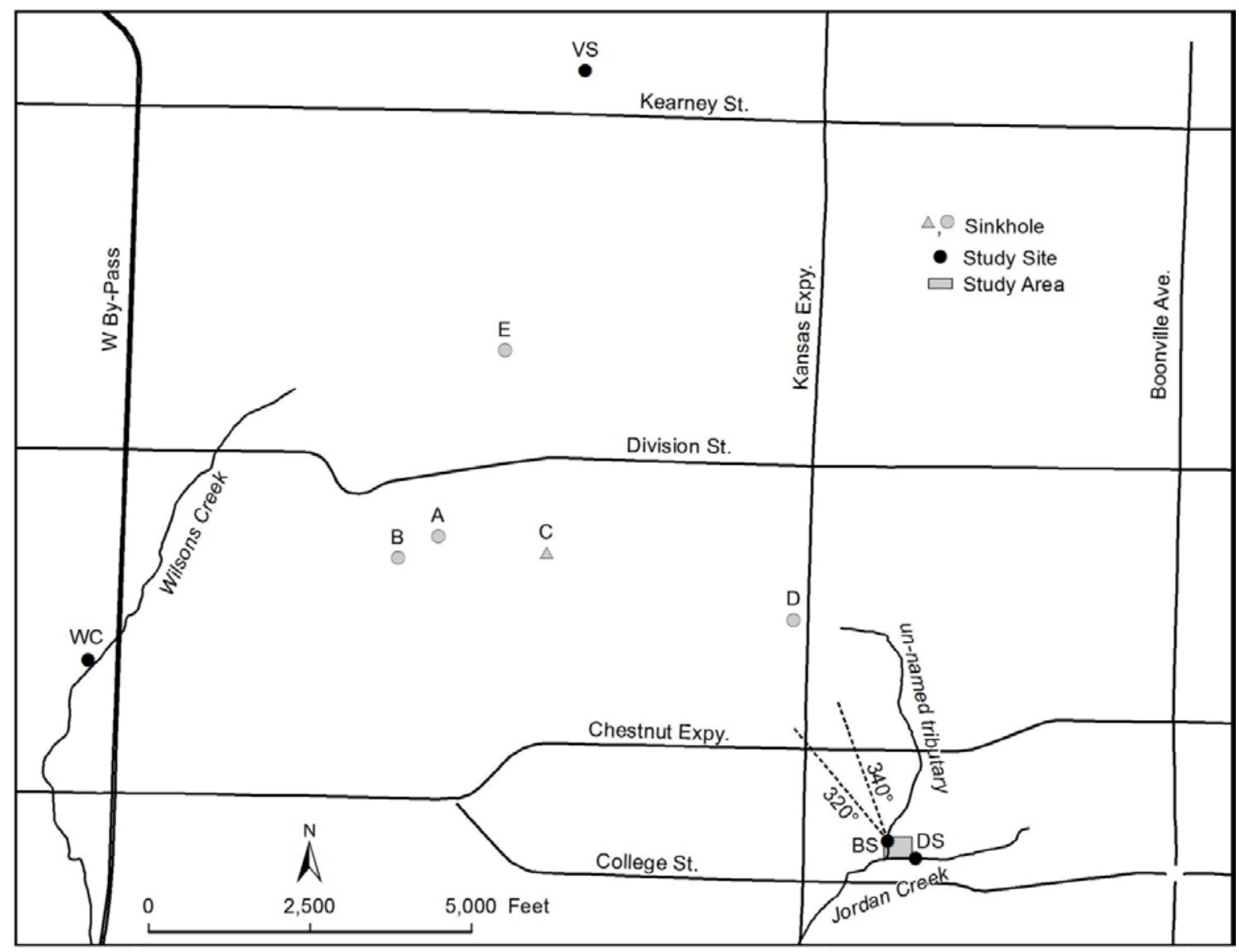

Figure 1. Brownfields study site and area features within Springfield city limits. Point BS is Brewery Spring, point DS is Diesel Spring, point VS is Vich Spring, and point WC is a monitoring location on Wilsons Creek. Letters A through E are sinkhole locations discussed in the text. The shaded area is the outline of figure 2, the study site. The dashed lines are potential fracture trends. Springfield's downtown square is at Boonville Avenue and College Street. 
Both the Springfield Plateau and Ozark aquifers exhibit numerous features and flow patterns consistent with karst conduit flow. Recent studies in the area surrounding Springfield have indicated that much of the shallow groundwater flow system is controlled by hydraulically conductive vertical joints and relatively horizontal conduits congruent with bedding planes (Gouzie and others, 2010; Berglund and Gouzie, 2012; Berglund and others, 2012).

\section{Site History}

The city of Springfield was founded in the 1830s along the banks of Jordan Creek and near a spring on the Fulbright homestead. By the start of the $20^{\text {th }}$ century, the central business portion of Springfield extended from about 0.75 mile south of Jordan Creek to1 mile north of Jordan Creek. The original railway station was located on or near the old Fulbright homestead. As Springfield grew, the growing railway moved toward the northern edge of the city (near the town of North Springfield), merging the two, and the original downtown railyard became essentially unused. Recent investigations indicate that roughly 75percent of the site study area was contaminated by industrial and railyard operations prior to the railroad transferring the property to the city (City of Springfield, 2013). A spring located on the south bank of Jordan Creek discharged hydrocarbons, earning the local nickname of "Diesel Spring" owing to the strong hydrocarbon odors common at the site. Subsequently, the city of Springfield began a Brownfields project to investigate and remediate the site area as part of an urban development project to create a greenway park corridor running along Jordan Creek through the urban core of Springfield.

\section{PROJECT ACTIVITIES}

Project activities at the Brownfields site included a preliminary investigation, contaminated soil removal, revegetation, and a number of other remedial actions by the city and its Brownfields Program contractors. During these efforts, some of the soil-removal activities uncovered a spring buried beneath the bed of a (usually) dry drainage tributary to Jordan Creek. Backhoe activities breached what apparently was a confining bed within the Burlington Limestone and allowed a rise pool spring to form. As this rise pool flowed, globules of discolored and odoriferous hydrocarbon contamination issued regularly from within the pool at intervals spaced from a few seconds to a few minutes apart. These globules dispersed as an oily sheen on the surface of the spring water as it flowed approximately 200 feet down the tributary reach and into Jordan Creek. Also of note was that the previously existing Diesel Spring located offsite, on the south bank of Jordan Creek and approximately 125 feet upstream, had been experiencing the same intermittent hydrocarbon contamination. A few days after the onsite spring was uncovered by the backhoe, Diesel Spring ceased flowing and was not observed to flow during the remainder of the project. For the purpose of this report, the new onsite spring will be called Brewery Spring.

After discovering Brewery Spring, the city and its contractors sought someone with expertise to conduct a dye trace to determine the source of the spring water and the likely location of the hydrocarbon contamination source. Geophysical studies were proposed by the authors to aid in focusing the dye-trace investigation.

\section{Sub-Contractor Status}

The authors were selected as sub-contractors to the city's primary remedial contractor for this portion of the Brownfields project. That decision relegated dye tracing and geophysical tasks to a secondary status compared to other site activities and timelines already established for site investigation and remediation. It also allowed access to the otherwise closed site, which was permitted through agreements already negotiated by the remedial contractor.

\section{Field Reconnaissance}

Field reconnaissance was conducted during the first calendar quarter of 2013. In addition to meeting the primary remedial contractor and going over their site procedures, a brief reconnaissance of the prospective geophysical study area was conducted and the timing of geophysical fieldwork was planned. Following these initial activities, topographic maps were reviewed and a cursory driving assessment was 
conducted of areas north and south of the site to investigate the suitability of local sinkholes for the dye injection. Suitability was defined as 1) property access, and 2) documented stream losses or a clear indication that water could disappear underground if conditions were wet.

\section{Site Geophysical Study}

After site reconnaissance was completed, it was determined that direct current (DC) electrical resistivity profiles would likely offer the most useful results and that electromagnetic (EM) surveying would also be used in order to offer a more robust interpretation than one method alone would offer. The resistivity and EM surveys were conducted in the second calendar quarter of 2013 and a geophysical report was prepared in early May 2013. Results and interpreted fracture or joint orientations from the resistivity data are shown in figure 2 .

Using the geophysical report, a meeting was held with the primary remedial contractor to discuss the results and implications for dye tracing and the selection of appropriate sinkholes for dye injection.
As can be seen on figure 2, the most promising trend for fractures running through the new onsite spring appeared to be along an azimuth trending between about 320 and 340 degrees. This trend also correlated well with the trend between the old (now dry) contaminated Diesel Spring offsite on the south bank of Jordan Creek and a line projected from that spring through the new onsite Brewery Spring, a line that would trend at an azimuth of approximately 305 degrees.

\section{Dye-Tracing Study}

As is usually the case with any dye-tracing study, the initial tasks were to identify potential tracer-injection locations and, in the case of unknown conditions, to identify all potential dye-resurgence locations surrounding the injection point.

\section{Dye-Injection Point Locations}

Using both topographic maps and driving tours of the area (and walking possible sites where property access allowed), five potential sites were considered, and these sites were identified by letters A through $\mathrm{E}$ on figure 1 .

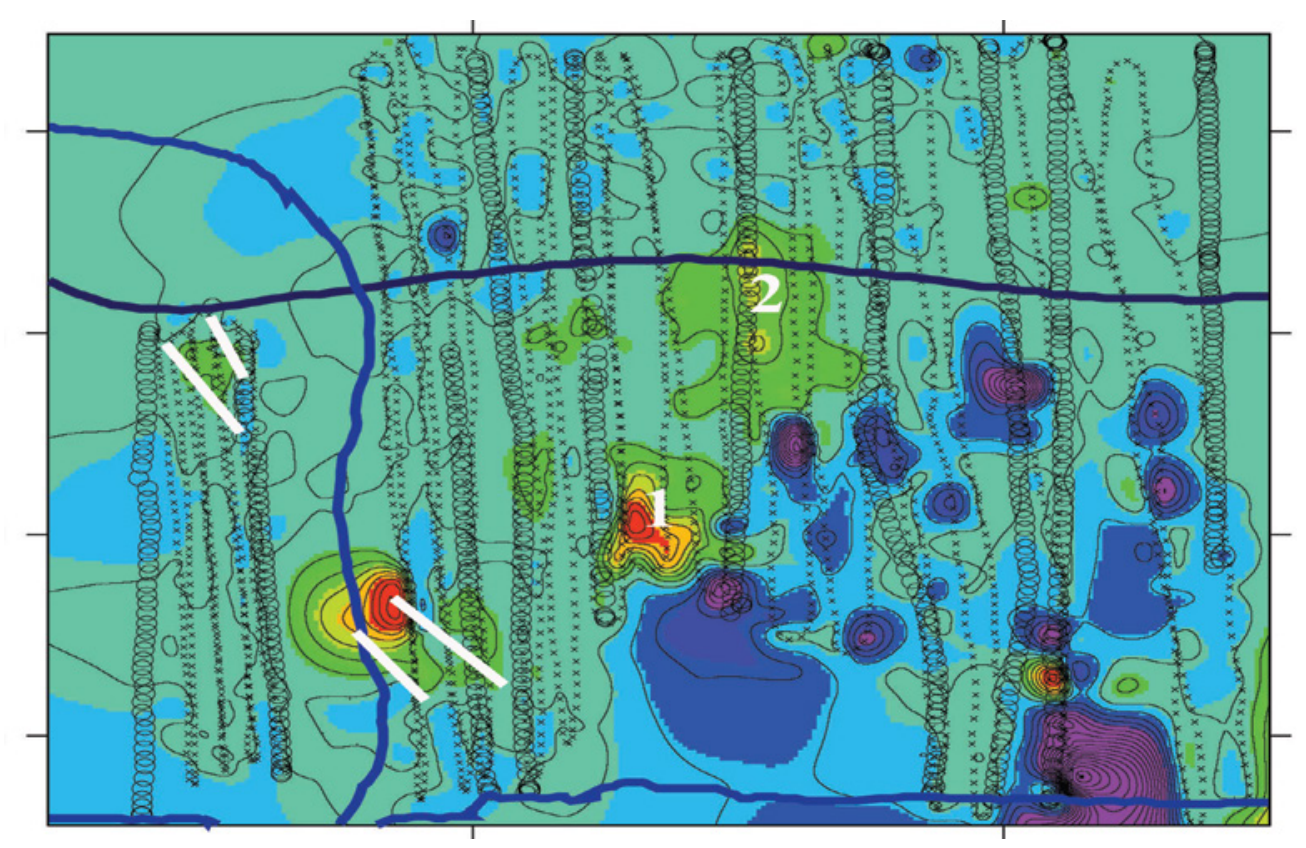

Figure 2. Electrical conductivity map of the Brownfields site as determined from the electromagnetic survey. White lines indicate the possible location of fractures determined from electrical resistivity profiles. Numbers 1 and 2 represent high conductivity regions on the electromagnetic profiles. Dark blue areas represent areas of site debris. Small rows of circles are the locations of the resistivity lines (each circle represents an electrode location.) This figure is the shaded area in figure 1 with north oriented toward top of page. 
A. small sink in field north of Calhoun Street (private property),

B. small sink in unused residential lot on northeast end of Scott Street,

C. sink used as city stormwater drain on northwest corner of West Avenue and Calhoun Street,

D. small sink immediately west of Kansas and Nichols Streets, and

E. sink mapped at west end of railyard north of Division Street.

Possible sinkholes south of the site were also evaluated, but no apparent sinkholes near any of the projected azimuths were identified from topographic maps to the south of the site, probably due to the more developed or urbanized grading south of College Street.

Based on preliminary reconnaissance, the lack of any discernible physical openings (swallow holes or sinkhole depressions with open "throats") removed two of the sites (B and D) from further consideration. The inability to gain access to the Division Street railyard eliminated the sink at location $\mathrm{E}$ from consideration. Of the two remaining sites, the corner of West Avenue and Calhoun Street (location C) was selected as the preferred dyeinjection location based on closest linear distance to the Brownfields site and also based on its current use as a stormwater drainage structure for the city of Springfield's stormwater drainage system. A photograph of this site and the stormwater inlet structure, a slotted pipe made of welded steel approximately 3 feet in diameter and surrounded by coarse gravel, is shown in figure 3 .

\section{Dye-Monitoring Point Locations}

Five monitoring locations were selected for the dye trace. These monitoring locations were:

1) Jordan Creek on the West Meadows site, upstream (east) of the confluence with the Brewery Spring tributary,

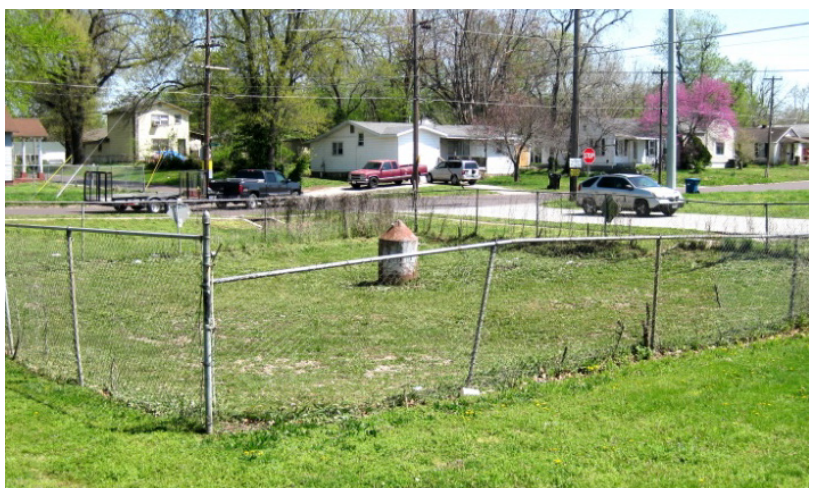

Figure 3. Dye-injection site at West Avenue and Calhoun Street.

2) BS-The new onsite Brewery Spring (the anticipated resurgent location for the dye),

3) VS-An unnamed drainage northeast of the dye-injection point (this drainage was the approximate location of "Vich Spring" where historical dye traces from north of the Division Street railyard had been detected),

4) WC-A wet portion of the north branch of Wilsons Creek to the west of the injection point, and

5) Rader Spring, on the banks of Wilsons Creek several miles south of site WC (a "catch all" location in the southwestern part of the metropolitan area).

This array of monitoring points was designed to cover streams north, west, and south of the site, in addition to the onsite Brewery Spring, and one upstream Jordan Creek site designed to detect any dye resurging east of the site. Charcoal packets (which adsorb the dye) were placed at each of these locations and an automated water sampler (Hach 900) was also utilized at the Brewery Spring site. All monitoring sites were sampled either with charcoal packets or grab sample bottles (or both) for analysis of the natural background fluorescence prior to selection of a dye for the trace. Based upon the background sample analyses, no interferences were found within the spectral wavelengths associated with Rhodamine WT dye (RWT), and it was selected for the test. 


\section{Dye-Trace Injection Details-Problems and Challenges}

Based partly on contractor schedules, it was decided to inject the RWT as promptly as possible. Groundwater tracers in Missouri are regulated so that only those trained in proper use of photochemical dyes should be injecting suitable amounts of dye into the state's waters. The regulatory program also requires prenotification of the Missouri Department of Natural Resources before injecting any dye to prevent interference with any existing dye traces already underway. These steps delayed the first trace until after a rainfall event on Monday, May 20. Based on weather forecasts of no other rainfall for that week, arrangements were made to use city water from a nearby fire hydrant for the actual dye injection. On Thursday, May 23, starting at approximately 2:30 pm, approximately 500 gallons of city water were flushed into the stormwater inlet, followed by 2 gallons of RWT dye (Koch Industries, 20\% solution). This was followed by approximately another 400 additional gallons of city water to continue flushing the dye into the stormwater structure, and into the shallow aquifer.

Based on past experience in the region and map distance from the stormwater injection site to the Brewery Spring, an estimated dye (groundwater) travel time of approximately 3036 hours was expected. Therefore, the automated sampler was programmed to collect a sample every hour for the first 24 hours, beginning at $6 \mathrm{pm}$ Thursday, May 23; the unit was refilled with clean bottles and reset at 24hour intervals after that.

Unfortunately, the unit experienced a malfunction (battery, timer, or programming issue) at the beginning of the second 24-hour interval (i.e., the first 24 hourly samples were collected, then the unit failed to collect samples for hours 27-42 after dye injection before the malfunction was discovered.) An identical (substitute) Hach unit with an alternate battery was placed onsite approximately 44 hours after dye injection, and the second unit operated properly for the following week. The onsite charcoal packet placed next to Brewery Spring was expected to serve as a backup for any issues, such as the autosampler failure.

The charcoal packets for the first 2 weeks onsite displayed significant interference with the detection (or more likely the sorption) of RWT. Although background interference samples were collected prior to the traces, the project timeline was met by evaluating potential interference with grab-sample bottles of water from the monitoring locations rather than waiting for charcoal packets to be retrieved from the field, dried, and processed. No interference was observed with detection of RWT in any of the background grab samples.

When the charcoal packets were analyzed, it appeared that the organic contamination at the site either preferentially adsorbed to the charcoal or otherwise had such a strong signal when eluted from the charcoal as to significantly obscure any RWT signal. Given the nature of the hydrocarbon contamination (almost certainly hydrophobic based on the globules and oily sheen onsite), it is reasonable to believe that the contamination preferentially sorbed on the charcoal and limited the sorption of the hydrophilic RWT on the charcoal. An example fluorometric scan of the analysis of a charcoal sample with detectable RWT is shown in figure 4.

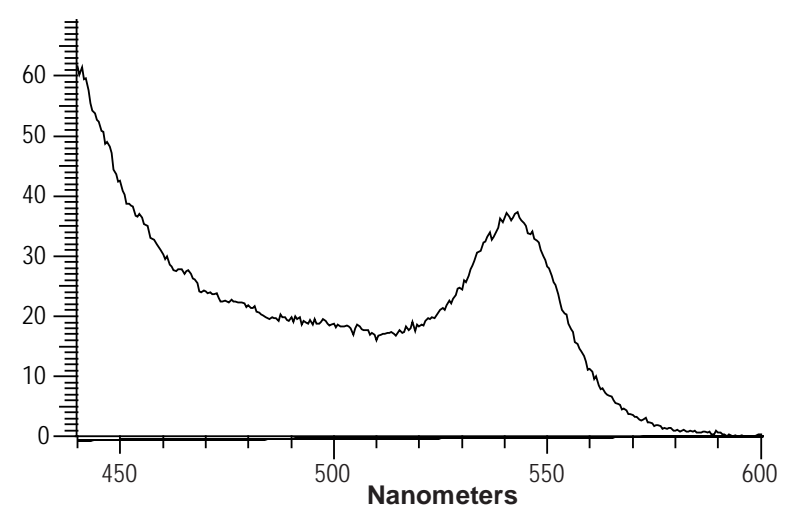

Figure 4. Fluorometric synchronous scan of sample charcoal packet elutant from Brewery Spring, showing a notable RWT peak at about $545 \mathrm{~nm}$ of excitation, and a much stronger but unknown peak around $440 \mathrm{~nm}$ excitation. The Y-axis of the figure is in fluorescence intensity units recorded by the fluorometer. 
Due to the autosampler malfunction, the Brewery Spring charcoal packet was changed on the morning of May 24, as scheduled, and then again late in the day on May 25, to cover the specific period of autosampler malfunction.

As shown in figure 4, it appears the charcoal sample from the Brewery Spring site collected on May 25 does show the presence of RWT. However, the amount of fluorescence is well below the threshold used in our lab of at least three times the fluorescence value of a pre-trace background sample in order to declare the sample a positive dye recovery. After discovering this interference, the charcoal packet monitoring location for Brewery Spring was moved approximately 100 feet downstream on Jordan Creek (to the underpass of Fort Avenue) in an attempt to allow site contaminants to dilute or disperse more before encountering the charcoal, and thus allowing the RWT dye to have a greater chance of sorbing on the charcoal.

Because dye concentration and duration did not match our lab requirements of a positive trace during the first 48 hours, the autosampler was re-stocked with clean bottles and programmed to continue sampling on a regular basis. The charcoal packets were also removed and replaced on a weekly schedule.

On May 30, approximately 1 week after sampling began, an intense storm event (approximately 2 inches of rain in less than 4 hours) occurred in the Springfield area, causing a significant flooding event in the onsite northsouth tributary where Brewery Spring is located. The flooding during this event was so extensive that the autosampler, secured about 5 feet above normal spring stage, was apparently floated downstream and overtopped by flood water. The chain securing the autosampler in place apparently caused the unit to be submerged in enough water to flood and short-out the main circuit board. As a result, no spring water samples were collected from May 30-June 14. However, throughout this time period, charcoal packets were maintained at all locations (including Brewery Spring) and continued to be changed and analyzed on a regular basis. With the exception of the one possible interferencemasked detection noted above during the first 48 hours after injection, at no point in time did elutant from any charcoal packet at any monitoring location show a positive detection for RWT.

After the first major storm event and replacement of the failed autosampler with a functional unit, plans were made to re-introduce more of the same RWT dye into the same sinkhole. Although a second injection of the same dye would add a level of uncertainty to the actual travel time (as it would not be possible to prove which injection was being detected), it was more expedient than the delay which would have ensued in using a second dye such as fluorescein (an alternate dye would have required additional approval of the Missouri Department of Natural Resources.) This expedient use of RWT for the second trace attempt was deemed acceptable because the primary purpose of the project (for the Brownfields site work) was to identify a connection between a sinkhole and the Brewery Spring.

This second dye injection was planned to coincide with an anticipated storm event in midJune. On the morning of June 15, 2 gallons of RWT were injected into the same West and Calhoun Streets stormwater sinkhole (location C) on the leading edge of a storm hydrograph, during the first 30 minutes of storm runoff. After injecting the dye, the authors travelled to the onsite Brewery Spring to check the autosampler unit. Upon arrival at the site, a visual discharge estimate of approximately 35 to 40 cubic feet per second $\left(\mathrm{ft}^{3} / \mathrm{s}\right)$ was made. The approximate discharge was calculated by multiplying the average of width times depth times velocity, with velocity determined by measuring the time it took a floating object on the water surface to move downstream a known distance. Because previous estimates of discharge from Brewery Spring typically had been in the range of 3 to $6 \mathrm{ft}^{3} / \mathrm{s}$ or less using the same visual estimation method, it appears that the urban runoff from the rain event of June 15 may have diluted the dye recovery to a point where once again it would be undetectable.

After the June 15 injection, monitoring was continued with both the autosampler and 
charcoal packets and in the surrounding area, although the West Bypass charcoal packet site went dry approximately June 21, which indicated no dye could resurge along that segment of stream. Monitoring was continuedfor 8 weeks after the initial dye injection on July 17, at which time the primary remedial contractor for the site chose to cease all further tracing activities. Using the criteria of the Missouri State University Cave and Karst Lab, no dye was ever definitively detected from either injection. Plans were made for another trace at a future time during wetter weather; however, the contractor's work plan and site access ended before any additional traces were attempted.

\section{DISCUSSION OF CHALLENGES}

Below is a brief summary of the challenges encountered beyond the normal issues found in dye tracing and field work. Also offered are some possible causes or major contributing factors to the challenges and possible ways to mitigate the issues.

\section{Urban Stormwater Issues}

One key issue was the unseasonal weather combined with the flow regimes of urban stormwater runoff. As noted above in the dyetracing section, both attempts at a successful trace were hampered by unusual and unexpected rainfall runoff. The first dye-injection event was impacted by a small but intense rainstorm which, based on water levels at the Brewery Spring, probably generated stormwater runoff at the site that was at least 10 times greater than typical baseflow at the site. Visual discharge estimates shortly after the second dye injection suggested that runoff in the site tributary containing Brewery Spring was in the range of $40 \mathrm{ft}^{3} / \mathrm{s}$. The stage associated with this discharge was below the elevation of the onsite autosampler, so water levels high enough to float and flood the autosampler would need to have been in excess of $40 \mathrm{ft}^{3} / \mathrm{s}$. Such large variations in flow were particularly challenging in determining amounts of dye to inject.

Groundwater tracers in Missouri are regulated, therefore, it is expected that registered dye-tracing professionals will limit the amount of dye injected to an amount that would not be expected to discolor any waters of the state.
Flashy urban runoff poses the challenge of diluting a normal injection amount to become so dilute as to no longer be detectable. The easiest way to overcome this challenge is to find a losing stream rather than an existing storm drainage structure, which may lead to groundwater but where the current groundwater connection cannot be observed or determined.

A recently located segment of losing stream northeast of the Brewery Spring site shows promise for a future dye-tracing attempt.

\section{Contract Limitations on Study Timeline}

As noted, this work was performed under a sub-contract to the city's primary remedial activity contractor for the site. Because the Brownfields Program is intended to accelerate redevelopment of urban lands, the project already was on a strict timeline before the authors were contacted for involvement.

The applied approach of determining the source area for a springfed stream created a challenge because typical tracing approaches using a point of known, ongoing flow into the subsurface were hampered by the desire to keep the tracer test moving forward on the established timeline. Adding the seasonal nature of study activities (pre-leafout being preferred for geophysics activities and post-freezing, wetseason weather preferred for dye tracing) to the already existing schedule posed challenges for a successful completion.

The ability to perform site geophysical studies quickly after study approval by the primary remedial contractor was a positive item - all parties were pleased to see activity onsite soon after approval of the proposed workplan, and the ability to perform the geophysical surveys during winter plant dormancy was fortunate. However, the additional insight offered by the geophysics and the time consumed by geophysical tasks did add increased pressure to the timeline and success of the dye trace. The desire to establish a successful dye trace led the authors to offer to conduct another trace after the project had officially ended.

Although such a tracer test is still planned, the added challenges of negotiating site access 
after the primary remedial activity contract has ended have delayed any new dye-trace attempts. Although site access was relatively easy under the umbrella of a site contractor, reaching an agreement on liability that satisfies the city's normal contract for property access and which is acceptable to the university (as a state agency limited in liability waivers to which it can agree) requires time-consuming negotiations between attorneys with more pressing legal issues on their schedules.

\section{Contaminant Interference with Dye}

Discovered during the first dye injection, the hydrocarbon contamination that prompted the investigation may also have interfered with detection of the dye by preventing sorption of the dye on the activated charcoal in the packets. Although fluorescence in the narrow wavelength range of RWT was detectable using a modern scanning spectrofluorometer, the intensity and recurrence was not enough to meet the Missouri State University Cave and Karst Lab criteria for a definitive detection. It appears that moving the Brewery Spring charcoal detector packet slightly downstream from the contamination source may have adequately overcome the challenge of contaminant interference, but this remains to be tested. The use of larger amounts of dye is also planned for future efforts, as the existing contamination of the site makes the issue of discoloration of the water less offensive during the remedial project. Local residents are already offended by the strong hydrocarbon odors and the oily sheen, so a brief period of slightly tinted water would likely be tolerated in order to achieve a definitive trace and move the remedial efforts forward.

\section{Geophysics - Guidance or Misguidance?}

Perhaps the most puzzling challenge encountered is the utility of using geophysical data in guiding or shaping the dye-tracing efforts. Although geophysics as used on the site have become very useful in other parts of the metropolitan Springfield area (Berglund and others, 2012; Gerson and others, 2012), it is unclear whether the geophysics contributed to a better understanding of the site subsurface or if it led investigators down a "primrose path."
Given the reasonable prediction of a groundwater feature trending at azimuth 305 degrees (based on the Diesel Spring going dry soon after the onsite Brewery Spring was uncovered), a reasonable interpretation of the geophysics data indicates linear features trending in azimuths ranging from 320 to 340 degrees and in general agreement with the 305degree azimuth trend. However, none of the discovered sinkhole features were actually in the geophysics-predicted range. The closest sinkhole discovered during the initial study, the urban stormwater drain at West and Calhoun Streets, is roughly on a 305-degree azimuth from the site, but there has not yet been a successful dye trace from this location. A newly discovered sinking stream segment that shows great promise is actually slightly northeast of the site and is in the upper reaches of the stormwater channel tributary running onto the site.

Given the location of the newly discovered sinking stream segment, it seems worth revisiting the geophysical data and considering the other low-resistivity features (marked as areas 1 and 2 on figure 2). It is possible that these features represent contamination that may be closer to a trend between the sinking stream segment and Brewery Spring. It also is possible that Jordan Creek itself is losing flow underground on the eastern edge of the downtown area, and that the lost flow is resurfacing at Brewery Spring after picking up some contamination in the east-west-trending alluvial fill in the Jordan Creek valley. Understanding that the historical Jordan Creek meandered across the east-west-trending valley through downtown, but is now channelized on the southern margin of the valley due to urban development, may open up new interpretations of site geophysics related to groundwater (and contaminant) movement. Hopefully a successful dye trace conducted in the near future will offer more data for a combined geophysical hydrogeologic interpretation.

\section{CONCLUSIONS}

Based on the challenges encountered, much was learned about modifying a traditional dyetracing research project into an applied site 
investigation and remedial effort under the U.S. EPA Brownfields Program.

Lessons learned for future studies include the following:

- Be flexible in using the entire karst toolset to adapt to schedule pressures of commercial contracts and timelines. Being able to use additional methods such as geophysics during weather conditions not conducive to dye tracing was helpful to the overall success of the project.

- Remember that the site is already contaminated and undesirable side effects of the current tasks may be more tolerated than they would be at undisturbed research sites. The hydrocarbon contamination driving this project may have interfered with the sorption of dye at the part-per-billion levels typically used in modern tracing, whereas higher levels up to a few hundred parts-perbillion for brief periods might have been tolerated as the cost of moving site remediation forward.

- Maintain the fundamental principles of the simplest research approach. Staying true to traditional dye tracing under "normal" conditions of existing streamflow losing to the subsurface and re-surfacing at a spring would have led to increased searching to locate losing stream segments in the urban area, or more searching for city employees familiar with past use, now covered, of the natural karst drainage features incorporated into the city's stormwater system. Knowledge gained after the unsuccessful traces were reported has provided at least two additional potential dye-injection locations that are anticipated to yield more successful traces in the near future.

Overall, the interaction with remedial and urban managers was a satisfying experience and one that is encouraged for all researchers. However, those used to research projects designed and conducted with few, or no, external pressures or timelines, should be prepared for the challenges involved in applied urban studies in karst areas.

\section{REFERENCES}

Berglund, J., and Gouzie, D., 2012, Conceptualizing flow interaction and conduit geometry in nearsurface karst using a quantitative dye tracing method: Geological Society of America Abstracts with Programs, v. 44, no. 5, p. 20.

Berglund, J., Mickus, K., and Gouzie, D., 2012, Studying urban karst features using near-surface geophysics in Springfield, Missouri: Geological Society of America Abstracts with Programs, v. 44, no. 5, p. 27.

Brahana, V., 2011, Ten relevant karst hydrogeologic insights gained from 15 years of in situ field studies at the Savoy Experimental Watershed, in Kuniansky, E., ed., U.S. Geological Survey Karst Interest Group Proceedings, Fayetteville, AR, April 26-29, 2011: U.S. Geological Survey Scientific Investigations Report 2011-5031, p. 132-141.

City of Springfield, Missouri, 2013, Jordan Valley West Meadows Project Fact Sheet, accessed at www.springfieldmo.gov/brownfields

Gerson, L., Mickus, K., and Gouzie, D., 2012, An urban karst geophysical study in Springfield, Missouri: Geological Society of America Abstracts with Programs, v. 44, no. 7, p. 78.

Gouzie, D., Dodd, R., and White, D., 2010, Dye tracing studies in southwestern Missouri, USA: Indication of stratigraphic flow control in the Burlington Limestone: Hydrogeology Journal, v. 18, no. 4, p. 1043-1052.

Imes, J.L., and Emmett, L.F., 1994, Geohydrology of the Ozark Plateaus aquifer system in parts of Missouri, Arkansas, Oklahoma, and Kansas: U.S. Geological Survey Professional Paper 1414-D, 127 p.

Luhmann, A., Covington, M., Alexander, S., Chai, S., Schwartz, B., Groten, J., and Alexander, E., Jr., 2012, Comparing conservative and nonconservative tracers in karst and using them to estimate flow path geometry: Journal of Hydrology, v. 448-449, p. 201-211.

Springfield Business Development Corporation, 2013, Springfield area Chamber of Commerce website, Live in Springfield, Climate in Springfield, accessible at http://www.liveinspringfieldmo.com/live/climate 


\title{
SPELEOGENESIS, GEOLOGIC FRAMEWORK, GEOPHYSICS, AND GEOLOGIC HAZARDS
}

\section{The Role of Spongework in the Speleogenesis of Hypogenic Caves in the Guadalupe Mountains, New Mexico}

\author{
By Mark Joop \\ New Mexico State University, Carlsbad, New Mexico 88220
}

\begin{abstract} pipes and tanks.

\section{INTRODUCTION}

Spongework has been recognized in the caves of the Guadalupe Mountains as far back as 1949, when Bretz wrote, "Carlsbad's magnificent display of spongework is to be seen from the highest to the lowest levels of the cave," and "the spongework of the [Left Hand] Tunnel is unsurpassed in any cave that the writer has ever seen” (Bretz, 1949). It is clear from Bretz's statements that he had seen spongework in caves in other areas (e.g., Meramec Cave in Missouri and Wind Cave in South Dakota). In fact, Bretz studied over 100 caves in 50 states, including Carlsbad Cavern, and coined the term "spongework" for the cave morphology discussed here (Bretz, 1942). Thus, while the spongework in Carlsbad Cavern was not cited as the type locality (White, 1988), it is definitely an excellent example of the relation between spongework and hypogene speleogenesis.
\end{abstract}

Recent studies of the few active sulfuric acid caves in the world have shed some light on the interpretation of relic sulfuric acid caves in the Guadalupe Mountains, New Mexico. The Guadalupe caves share most of the common features, including spongework morphology. The spongework clearly predates the hypogenic speleogenesis in the Guadalupe caves and provided the cavernous porosity needed to form the sulfuric acid subaerially. The generation of sulfuric acid requires an abundant supply of sulfur and oxygen. It is argued that the hydrogen sulfide came from microbial reduction of the abundant sulfate in the brine water, and that the oxygen came from the atmosphere in the spongework above the water table. A modern analog of how sulfuric acid is produced in caves may be found in concrete wastewater

The purpose of this paper is to re-examine the spongework in Carlsbad Cavern and Spider Cave, as type localities in the Guadalupe Mountains, in light of more recent work, to determine its role in the speleogenesis of these caves.

\section{DEFINITION OF SPONGEWORK}

Spongework is defined in the Lexicon of Cave and Karst Terminology as "Randomly shaped cavities created by undirected phreatic dissolution in a massive, essentially homogeneous limestone” (USEPA, 2002). Earlier definitions focused on the morphology of spongework, and did not include its genesis. Palmer (1991) defined spongework as "interconnected solution cavities of varied size in a seemingly random three-dimensional pattern like the pores of a sponge.” White (1988) had earlier defined spongework as "interconnected, nontubular solution cavities of varied size and irregular geometry arranged in an apparently random, three-dimensional pattern,” but added that it "appears in caves formed in young, porous, and poorly jointed limestones.” Both Palmer (1975, 2005, 2007) and White (1988) categorize spongework as a feature of maze caves. While there are some divergent hypotheses on the genesis of spongework, most speleologists agree with Bretz that spongework is produced in the phreatic zone under slow, diffuse, hydraulic conditions (Klimchouk, and others, 2000). This is indicated by the smooth, rounded, irregular speleogens such as cupolas, holes, pendants and bridges, the lack of scallops and channels, and the irregular floors and ceilings. Bretz deduced that spongework is "the solutional work of water without definite current, without surface gradient, without air above it."

Modern investigations of spongework caves not associated with hypogenic speleogenesis 
have determined that this morphology formed by corrosion at the fresh/salt water mixing zone of coastal aquifers; such caves are now called flank-margin caves (Mylroie and Carew, 1990). The mixing can be explained by the hydraulic action of tides, penetrating into the bedrock as far as the hydraulic conductivity of fractures, joints, and bedding planes allow, which would increase with time as porosity and transmissivity increased due to corrosion. Constant mixing is essential to maintain aggressiveness, which is initially most active close to the coastline. The mixed water is corrosive to limestone because it is undersaturated with respect to calcite (Plummer, 1975; Bogli, 1980). Spongework caves are found in a wide variety of carbonate lithologies (Klimchouk and others, 2000), though primary porosity is believed to be important (Palmer, 2005, 2007). The large chambers of flank-margin caves appear to be due to the coalescing of cupolas and holes, often leaving remnants of the rock in between as pendants protruding from the ceiling, walls, and floor (Mylroie and Carew, 1990). Spongework is not a common cave morphology (White, 1988), yet with so many relic and active spongework caves associated with emergent limestone in contact with seawater, perhaps the flank-margin environment, as opposed to being a special case (Klimchouk, 2000), is the common, or at least primary, geologic setting required to produce spongework caves. In other words, it is not mixing corrosion alone which best explains most occurrences of this phreatic morphology (Palmer, 2005), but this type of dissolution in combination with the low-velocity, turbulent, swirling, back and forth flow pattern associated with tidal action.

\section{NATURE OF SPONGEWORK IN CARLSBAD CAVERNS NATIONAL PARK}

The spongework in Carlsbad Cavern is variable in size, from walking passages to small holes that only a finger can pass through. This cave morphology is found around the perimeter and in between the large chambers (fig. 1). A nearly vertical fracture is typically observed in the center of the ceiling of the "trunk" passages, indicating that the spongework developed along this secondary porosity, and spread laterally on both sides of the fracture (fig. 2). Usually, the lateral development is not far from the fracture unless there are intersecting or parallel fractures, and is characterized by small interconnected pockets that dead-end. Even the trunk passages come to a dead-end, though the fracture usually continues. In Spider Cave, the spongework developed along a bedding plane contact between a sandstone member of the Yates Formation and the underlying dolomite. The natural floors of the spongework are not flat unless they have been filled in and leveled with secondary clay or sediment deposits (e.g., Big Room, Kings Palace/Lower Cave), which represent water table stands. Most of the spongework in Carlsbad Cavern is located at the Big Room level - the northeast ends (the Zoo, the Underground Lunchroom and all along Left Hand Tunnel), and the Boneyard (above Lower Cave spongework); at the Lower Cave level the northeast side; and at the Main Corridor level - the north side (the New Section).

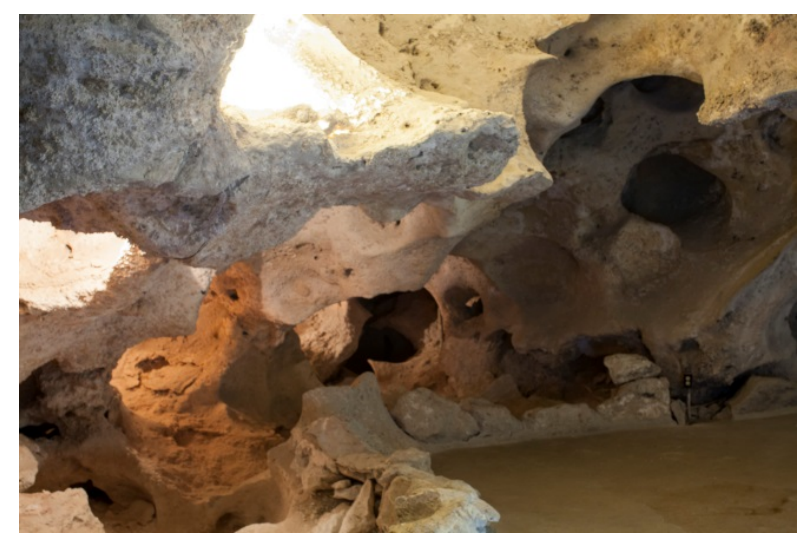

Figure 1. Typical spongework in Carlsbad Cavern.

In addition to pendants, rock bridges are another common speleogen found throughout the spongework, where the bedrock between holes is left suspended, with air space on all sides of the bridge (fig. 2). Some of these rock bridges are only a couple of centimeters in diameter at the thinnest spot. Typical of spongework in this and other caves, primary flow features such as scallops are absent (Klimchouk, and others, 2000).

The vertical extent of the spongework in Carlsbad Cavern is from the bottom of the lower sandstone unit in the Triplet Member of the Yates Formation, as can be seen in the Main Corridor and in the route to Hall of the White 
Giant, to at least the floor of Lower Cave in the Capitan Reef. Spider Cave formed at the same upper limit. This 5-meter thick sandstone unit may have been a groundwater confining layer. The vertical extent represents about 207 meters.

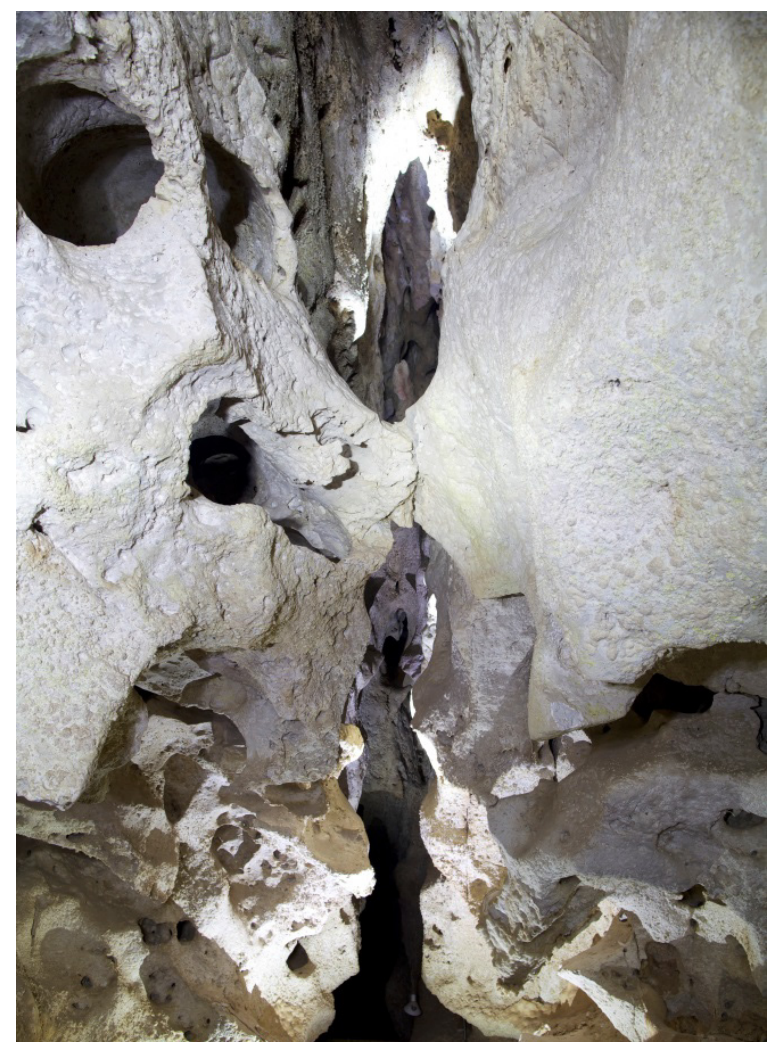

Figure 2. Fracture in the ceiling, with spongework on both sides. Note the rock bridge spanning across the fracture, as well as the one in the upper left corner of the picture.

\section{GEOLOGIC TIMING OF SPONGEWORK}

Because the spongework occurs around the perimeter and in between the large chambers of Carlsbad Cavern, Hill $(1996,2006)$ recognized that it pre-dates the sulfuric acid hypogene speleogenesis that occurred during the Miocene. The spongework represents the first stage of dissolution in the Guadalupe Mountains. Hill suggested that the timing of the spongework started no later than after the Permian and extended through the Mesozoic into the early Cenozoic, when the Delaware Basin was emerging (Hill, 1996). A date of early Jurassic (188 $\pm 7 \mathrm{ma}$ ) was provided by a speculative $40 \mathrm{~K} / 40 \mathrm{Ar}$ date for montmorillonite clay found in the spongework. Hill recognized that the reef complex had to be emergent for a freshwater lens to be present to create spongework, and with no Triassic- or Jurassic-age deposits in the Delaware Basin, this date made sense. But is the end of the Permian the first emergence of the reef complex? Most early workers agreed that the Delaware Basin was first tilted eastward at the end of the Permian, but there is strong evidence that this tilting occurred earlier (Hill, 1996).

The spongework developed along preexisting, near vertical fractures, the major ones being the same two sets on which most of the caves in the Guadalupe Mountains developed: one set parallel to the reef escarpment, and one set almost perpendicular to the reef escarpment. Strong evidence indicates that the earliest of these fractures are syndepositional with the reef, and Capitanian in age (Hunt and others, 2002; Kosa and others, 2006). Basin and Range extensional stress most likely reactivated these pre-existing fractures. When this evidence is coupled with the fact that the Ochoan-age evaporite deposits in the basin are wedgeshaped, thickening to the east, unlike the underlying Delaware Mountain Group, it seems reasonable to deduce that some eastward tilting of the Delaware Basin occurred at the end of the Guadalupian (Hill, 1996). Saller (1996) concluded that the reef complex had tilted $10^{\circ}$ basinward after deposition due to compactioninduced differential subsidence (the backreef deposits thicken toward the reef margin). Hunt and others (2002) refined this tilt to a $2^{\circ}$ depositional dip of the Yates Formation with an additional $6-8^{\circ}$ syndepositional tilting due to subsidence, which was believed to be responsible for the progradation of the Capitan shelf. However, during and/or after the deposition of the Tansill Formation, an additional $4-6^{\circ}$ basinward tilt occurred (Hunt and others 2002), which perhaps was due to tilting of the basin itself. Because the evaporites are the result of the Delaware Basin being cut off from the ocean to the west, then perhaps this cutoff was due to eastward tilting of the basin, as opposed to a drop in sea level.

Hill (1996) summarizes evidence supporting a strong case that the Castile sea did not cover the reef or forereef on the western side of the Delaware Basin, from the Guadalupe Mountains to the Apache Mountains, indicating that it was 
emergent during Castile time, and perhaps even during Salado time. If this is the case, then the freshwater lens required to create the mixing corrosion that produced the spongework was present as early as the Capitanian/Ochoan boundary (260 ma). Kirkland and others (2000) agree that the basin was closed off from the ocean during deposition of the 260,000 laterally correlative, varved lamina of the Castile evaporites due to the western reef complex being emergent. They show that the parent brine water of the Castile evaporites was predominantly marine, and that the source of the marine water kept pace with evaporation, such that desiccation never occurred. They conclude that the brine water entered the basin by seepage through the Capitan Formation, and the brine water level remained close to sea level.

\section{ROLE OF SPONGEWORK IN HYPOGENE SPELEOGENESIS}

That sulfuric acid hypogene speleogenesis was involved in the formation of the large chambers and passages that make the Guadalupe caves world famous is well accepted and supported today (Palmer, 2006). However, how this process works is still being studied. A recent comparison of active sulfidic karst systems in the world (Hose and Macalady, 2006) has found some common features: 1) thermal groundwater rich in sulfate, 2) sulfate-reducing and sulfuroxidizing chemoautotrophic bacteria, 3) the release of sulfides from the aquifer into the atmosphere of pre-existing caves/cavities, 4) the subaerial formation of sulfuric acid in the condensate on the walls, 5) gypsum rinds on the walls from limestone replacement, 6) massive gypsum floor deposits from stoped rinds, and 7) spongework cave morphology. The sulfuric acid production in the Guadalupe Mountains ceased long ago, which makes these caves relict. Even in Lechuguilla Cave, which intersects the groundwater table 488 meters below the surface, there is no sulfuric acid in the water or in the cave. Therefore, if the present is the key to the past, then observations made at active sulfuric acid caves would indeed aid in our understanding of the speleogenesis of Guadalupe caves.
As discussed above, the spongework in Guadalupe caves clearly pre-dates the sulfuricacid dissolution phase by at least 240 million years (the caves are believed to be 2-12 million years old, as determined by ${ }^{40} \mathrm{Ar} /{ }^{39} \mathrm{Ar}$ dating of alunite, a potassium-clay mineral that can only form in acidic environments; Polyak and others, 1998). Therefore, the age of the spongework, its existence along the perimeter and in between the large chambers having developed along the same fracture sets as the large chambers and passages, and that spongework remnants such as pendants and cupolas are seen in the bedrock of the large chambers, all suggest that the large chambers could be the result of enlargement of pre-existing spongework by sulfuric acid. The fact that most active sulfuric acid caves have spongework morphology has led some writers to think the relation is causal (e.g., Palmer, 2007). There are several reasons to believe otherwise: 1) sulfuric acid is very corrosive, so there is no reason to believe that it would dissolve limestone preferentially, creating sculpted interconnecting holes as opposed to uniform dissolution, 2) it would be hard to explain how so many rock bridges remain, when they can be attacked from all sides, 3) the gypsum rinds conform uniformly to the morphology of the spongework (fig. 3), as opposed to producing it, and the rinds are not found in the interior of the peripheral spongework, where they would be expected to survive, and 4) this morphology is produced phreatically, which would require the sulfuric acid to be created subaqueously, which is not observed in active sulfuric acid caves.

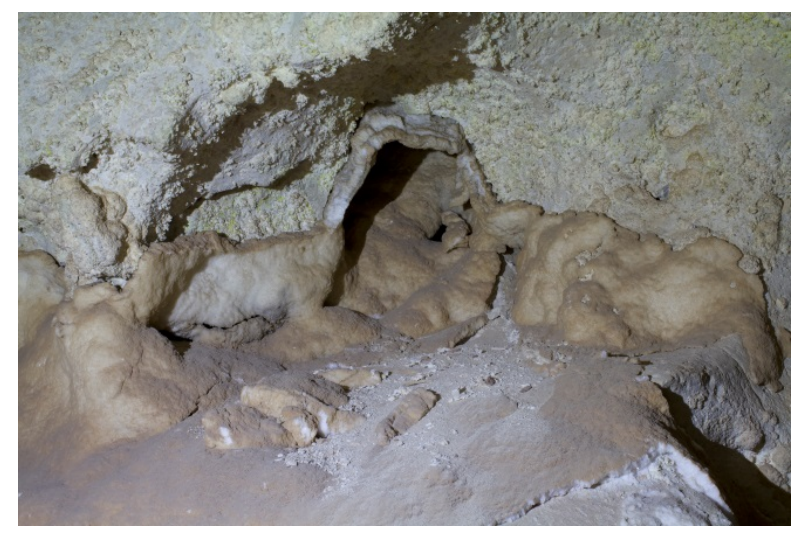

Figure 3. Gypsum rind on spongework. Note how the rind conforms to the shape of the spongework, even inside the hole. 
The relation between spongework and sulfuric acid appears to be related to the question of whether sulfuric acid forms subaqueously or subaerially, or both. Sulfuric acid in active caves is formed subaerially within the condensate on the walls. However, do the active sulfuric acid caves represent a late stage of development that is different from the initial stage, or are the observed processes consistent throughout the speleogenesis of these caves? This question is best answered by determining whether sulfuric acid can be formed subaqueously.

Hill never included spongework as one of the controlling factors in cave development. This was because she believed that the hypogenic caves cut across the previous stage, and because she believed the sulfuric acid was in solution below the top of the water table, where hydrogen sulfide $\left(\mathrm{H}_{2} \mathrm{~S}\right)$ gas rising through the brine water encountered oxygenated meteoric water and reacted with dissolved oxygen. But a review of the abiotic origin of sulfuric acid outside of caves and in the manufacturing process revealed that in each case, the acid forms in the atmosphere, not subaqueously. Sulfuric acid in its anhydrous form does not occur in nature because the hydration reaction is thermodynamically favorable $\left(K_{a 1}=2.4 \times 10^{6}\right)$, and so it has a strong affinity for water. Sulfuric acid is even used as a desiccant because of this property. The reaction is highly exothermic, and produces hydronium and sulfate according to the equations: $\mathrm{H}_{2} \mathrm{SO}_{4}+\mathrm{H}_{2} \mathrm{O} \rightarrow \mathrm{H}_{3} \mathrm{O}+\mathrm{HSO}_{4}$, and $\mathrm{HSO}_{4}$ reacts with water to form $\mathrm{H}_{3} \mathrm{O}+\mathrm{SO}_{4}\left(\mathrm{~K}_{\mathrm{a} 2}\right.$ $=1.2 \times 10^{-2}$ ). Therefore, sulfuric acid would not form in a medium that strongly forces it to dissociate.

Hill's concept of $\mathrm{H}_{2} \mathrm{~S}$ gas, produced by sulfate-reducing bacteria (SRB) thriving on the petroleum hydrocarbons that migrated up dip when the Delaware Basin tilted eastward during the Miocene uplift, bubbles up through brine water and reacts with dissolved oxygen in oxygenated meteoric water below the water table, is problematic on many accounts. The $\mathrm{H}_{2} \mathrm{~S}$ would not degas at pressures greater than a meter or two below the water table (Palmer and Palmer, 2000), so a transport mechanism would be required to move aqueous $\mathrm{H}_{2} \mathrm{~S}$ from deep in the basin where the petroleum deposits exist, to the water table within the shelf.

Hydrogen sulfide, which is only slightly soluble, reacts with water to form hydronium and $\mathrm{HS}: \mathrm{H}_{2} \mathrm{~S}+\mathrm{H}_{2} \mathrm{O} \rightarrow \mathrm{H}_{3} \mathrm{O}+\mathrm{HS}$. At the $\mathrm{pH}$ range of seawater (7.5-8.4), most available $\mathrm{H}_{2} \mathrm{~S}$ dissociates to $\mathrm{HS}\left(\mathrm{pK}_{1}=7\right.$ in pure water at $25^{\circ} \mathrm{C}$ ), and this occurs at lower $\mathrm{pH}$ with increasing salinity and temperature; HS is stable $\left(\mathrm{pK}_{2}=17\right.$ at $\left.25^{\circ} \mathrm{C}\right)$. Therefore, $\mathrm{H}_{2} \mathrm{~S}$ would have dissociated in the saline groundwater before it could reach meteoric water, especially if the water was above $25^{\circ} \mathrm{C}$.

Why would the meteoric water come to have such high levels of dissolved oxygen, which is usually low in mountainous areas due to a lack of soil (Palmer and Palmer, 2000)? This could only occur if the water was aerated as it traveled down epigenic conduits, which are not observed in Guadalupe caves, or there were air-filled cavities above the water table.

The abiotic oxidation of $\mathrm{H}_{2} \mathrm{~S}$ is very slow due to the lack of dissolved oxygen in groundwater and to kinetic constraints (Luther and others, 2011), but when it occurs in freshwater, it produces sulfur according to the equations: $2 \mathrm{H}_{2} \mathrm{~S}_{(\mathrm{aq})}+\mathrm{O}_{2(\mathrm{aq})} \rightarrow 2 \mathrm{H}_{2} \mathrm{O}+2 \mathrm{~S}$, or $\mathrm{H}_{2} \mathrm{~S}_{(\mathrm{aq})}+\mathrm{O}_{2(\mathrm{aq})} \rightarrow \mathrm{H}_{2} \mathrm{O}_{2}+\mathrm{S}$, not sulfuric acid. Biotic oxidation enhances the rate by three or more orders of magnitude, but the outcome is the same. This reaction most likely explains the occurrence of elemental sulfur found in sulfuric acid caves (e.g., Cueva de Villa Luz; Hose and Pisarowicz, 1999). If the source of $\mathrm{H}_{2} \mathrm{~S}$ is the petroleum deposits in the basin, why has the sulfuric acid process ceased, as there is still plenty of oil, and the Delaware Mountain Group formations still contain "sulfur water"?

All abiotic occurrences of sulfuric acid (acid rain) do not start with $\mathrm{H}_{2} \mathrm{~S}$, but with oxidized sulfur, usually sulfur dioxide $\left(\mathrm{SO}_{2}\right)$, which is oxidized in air (producing sulfur trioxide, $\mathrm{SO}_{3}$ ) in the presence of water vapor to form sulfuric acid. Sulfuric acid is the world's most important industrial chemical, and the manufacturing process also starts with $\mathrm{SO}_{2}$, which is obtained by either burning sulfur, or as an alternative, incinerating $\mathrm{H}_{2} \mathrm{~S}$ gas $\left(2 \mathrm{H}_{2} \mathrm{~S}+3 \mathrm{O}_{2} \rightarrow 2 \mathrm{H}_{2} \mathrm{O}+\right.$ $2 \mathrm{SO}_{2}$ ). In other words, the production of $\mathrm{SO}_{2}$ by 
the oxidation of $\mathrm{H}_{2} \mathrm{~S}$ cannot occur abiotically in water, nor is it going to occur in air (heat of formation $=-1,036$ kilo Joules per mole $[\mathrm{kJ} / \mathrm{mol}]$; compare to $\mathrm{S}+\mathrm{O}_{2} \rightarrow \mathrm{SO}_{2}=-297$ $\mathrm{kJ} / \mathrm{mol}$ ). The chemical equation that Hill used, $\mathrm{H}_{2} \mathrm{~S}+2 \mathrm{O}_{2} \rightarrow \mathrm{H}^{+}+\mathrm{HSO}_{4} \rightarrow 2 \mathrm{H}^{+}+\mathrm{SO}_{4}$, while thermodynamically feasible $(\Delta \mathrm{G}=-760.88$ $\mathrm{kJ} /$ mole for the first product), does not occur abiotically in water because of the kinetic constraints of three molecules of low concentrations due to low solubilities coming together at the same place at the same time to react. But can this reaction occur biotically in air?

Gypsum rinds are a common feature of active sulfuric acid caves, including Carlsbad Cavern and other Guadalupe caves, and they are best explained by subaerial replacement of limestone by sulfuric acid in the condensate (Hose and Pisarowicz, 1999). In fact, this subaerial process is believed to account for the greatest volume of carbonate dissolution in Guadalupe caves and in the Frasassi caves in Italy (Palmer and Palmer, 2012, and Galdenzi and Maruoka, 2003, respectively). The domed cross-sectional shape of Carlsbad Cavern, with its flat floors representing the water table, suggests that this cave formed subaerially (Palmer and Palmer, 2012). For sulfuric acid to be generated at the water table, as what appears to be the case for the Guadalupe caves, a constant supply of sulfur and oxygen is required, as both are consumed with the dissolution of limestone. If sulfuric acid is formed subaerially, then subterranean, humid air space directly above the water table, large enough for condensation to occur and have air flow (oxygen has to be replenished), is required. The preexisting spongework would have provided such an environment, and would have provided the necessary supply of oxygen, especially if the spongework had small connections (fractures) to the outside. But what was the source of sulfur to create the sulfuric acid?

The reason that Hill turned to $\mathrm{H}_{2} \mathrm{~S}$ as the source of sulfur is because the $\delta^{34} \mathrm{~S}$ isotopic values for the cave gypsum and sulfur are isotopically light (mean $=-16.8$ permil for 22 samples), which she could only ascribe to the fractionation that occurs by reduction of sulfate in the evaporites in contact with petroleum by
SRB. However, isotopically light $\delta^{34} S$ values appear to be common in active sulfuric acid caves that are not near petroleum reservoirs (Hose and others, 2000; Galdenzi and Maruoka, 2003). Another common feature of sulfuric acid caves is thermal, sulfate-rich, saline water. The main sulfur compound in seawater is sulfate; it is the third most abundant component of seawater by weight. $\mathrm{H}_{2} \mathrm{~S}$ is a negligible dissolved-gas component (outside of microbial action) because it quickly dissociates. The isotopically light $\delta^{34} \mathrm{~S}$ values can be explained by the fractionation due to SRB thriving in the thermal water near the aerobic/ anaerobic interface (water table). Perhaps the source of the high $\mathrm{H}_{2} \mathrm{~S}$ content in the water of active sulfuric acid caves is due to sulfate reduction by SRB in the caves, rather than a possible source upgradient of the caves. The biofilms in the streams in the Frasassi cave system were found to include predominantly gamma- and deltaproteobacteria (Macalady and others, 2006).

\section{A SULFURIC ACID SPELEOGENESIS MODEL FOR GUADALUPE CAVES}

The following model is based on studies of previous workers (Kirkland, 1982; Palmer and Palmer, 2000; Hose and others, 2000; Palmer, 2006; Hose and Macalady, 2006), combined with the author's own observations in the 4.5 years working at Carlsbad Caverns National Park.

The cave morphology of typical flankmargin caves includes a large chamber with spongework along the perimeter, the chamber being the result of the holes coalescing in an area of more aggressive dissolution. The spongework extends inland into the limestone via fractures or other secondary porosity. The spongework is the result of mixing corrosion at the freshwater lens/seawater boundary, and near the coastline where the freshwater lens is thinnest and the tidal action is more aggressive (Mylroie and Carew, 1990). This scenario is easily superimposed onto the geologic setting of the Guadalupe Mountains, an emergent reef complex due to the closure of the Delaware Sea 260 ma. Basinward tilting of the reef complex by syndepositional subsidence caused tensional fractures to develop parallel to the reef escarpment, as well as a nearly perpendicular 
conjugate set. These fractures, along with the vuggy porosity of the Capitan Reef massive, provided the avenues for both the infiltration of meteoric water and the horizontal penetration of seawater. At the fresh/salt water boundary, mixing corrosion occurred initially along these fractures, especially at intersections, but spread laterally as the fractures were enlarged, producing spongework caves at sea level. The vertical extent of the spongework indicates that either sea level dropped 207 meters after the Capitanian, or the western side of the basin was being tilted. Many of the caves in the Guadalupe Mountains occur near the escarpment, the late Permian coastline (Palmer and Palmer, 2000, fig. 2). Once the mixing zone intersected the backreef formations, spongework also began to develop along bedding planes (e.g., Spider Cave).

During Miocene Basin and Range tensional faulting, three western sections of the buried reef ring were in the path of the north-northwesttrending uplift. The section now known as the Guadalupe Mountains broke perpendicular to the reef at the Border Fault and was thrust upward at the fault about 1,500 meters from its late Permian position, analogous to pulling on a tire buried in the sand, where the tire was cut in two. The uplift was episodic, as evidenced by the flat cave floors at different levels, which represent long stands of the water table. This period was accompanied by rifting, flood basalts, igneous intrusions, and heating of the crust to over $50^{\circ} \mathrm{C}$ (Barker and Pawlewicz, 1987). This paleogeothermal gradient would have heated the groundwater as well, producing thermal convection upwelling. In Carlsbad Cavern, this upwelling may have occurred as a thermal spring at the Bottomless Pit, which is currently 18 meters deeper than Lower Cave (the lowest water table stand within the cave), the floor of which is very sandy, with stoped breakdown blocks. Another possible thermal spring may have occurred at Lake of the Clouds (63 meters deeper). The potentiometric surface for both springs was at the level of the Big Room floor at the time this chamber was enlarging. Bottomless Pit, which is on the same fracture as the large chambers of Lower Cave, was most likely the spring that also fed Lower Cave when the potentiometric surface was at that level, but the breakdown floor at the southwest end of the Big Room is covering the connection. Devil's Den may have been a thermal spring when the Main Corridor was enlarging, with the current bottom of the pit, where a gypsum block and rinds remain, being the potentiometric surface.

SRB, most likely thermophiles $\left(40-70^{\circ} \mathrm{C}\right.$ temperature range, with $50^{\circ} \mathrm{C}$ optimum), were thriving near the air/water interface in this warm, anaerobic, sulfate-rich brine water, with the densest colonies (biofilms and mats) at the spring orifices. The sulfate reduction produced $\mathrm{H}_{2} \mathrm{~S}$, most of which was released as a gas to the air-filled spongework above the water table.

Some of the $\mathrm{H}_{2} \mathrm{~S}$ dissolved in the brine water could have oxidized abiotically to $\mathrm{SO}_{3}$ (as well as to sulfur; Zhang and Millero, 1993), which then hydrated in the humid atmosphere to create sulfuric acid vapor that would eventually condense on the cooler walls and ceilings, but could travel away from the spring. The $\mathrm{H}_{2} \mathrm{~S}$ gas would have adsorbed onto the film of condensed and/or seeped water on the walls, where abiotic and biotic oxidation occurs using the oxygen in the cave atmosphere; this oxidation produces elemental sulfur. The sulfur is further oxidized by aerobic sulfur-oxidizing bacteria (SOB), such as Acidithiobacillus sp., to form sulfuric acid (Hose and others, 2000). The sulfur folia on the walls of sulfuric acid caves may be a remnant of this process.

Sulfuric acid generation would not have extended far from a thermal spring, due to the water becoming cooler with distance-not a conducive environment for mesophilic or thermophilic bacteria. The sulfuric acid caused the outer layer of limestone to be replaced with gypsum as a rind. This replacement could only penetrate into the limestone a limited depth, usually 5-15 centimeters, due to the rind acting as a barrier. The rinds allowed the $\mathrm{H}_{2} \mathrm{~S}$ gas and acid vapor to travel farther down passage in the direction of air flow. The ceiling height in the Big Room, which decreases from about 60 meters at the southwest end to about 6 meters at the northeast end, indicates that the acid was generated at the southwest end, and that the air flow was toward the Main Corridor at the northeast end. Once the cave system opened to 
the atmosphere by breaching the surface, $\mathrm{H}_{2} \mathrm{~S}$, which is heavier than air, would rise higher in the cave due to barometric convection and thermal gradients. This breach must have already occurred by the time the water table was at the level of the Big Room, as the rillenkarren on the limestone breakdown blocks of Appetite Hill (in the borehole passage between the Main Corridor and the Big Room) indicates that sulfuric acid condensate was still dripping at the point of ascension after the collapse. Original spongework is extant in the areas peripheral to the main path of air flow, as evidenced by the absence of gypsum rinds in the interior of the spongework.

The weight of a rind would cause it to peel off of inclined surfaces. As each rind fell off the walls and ceiling, a new layer of limestone became exposed to the acid, and the process would repeat itself, enlarging the spongework into the huge chambers we see today. The spongework provided greater surface area and less rock to dissolve. The height of the chambers and passages appears to have been controlled by both the vertical extent of the spongework (it does not continue above the ceilings) and the horizontal distance from the acid source. Above the Bottomless Pit spring orifice, the ceiling was under constant acid attack and a dome was created (Liberty Dome). Subsequent stoping increased the ceiling height where closely spaced vertical fractures occurred (e.g., southwest end of the Big Room and Appetite Hill).

The fallen rinds dissolved in the water, causing the water table to become saturated in gypsum, which eventually precipitated out as a blanket that covered the floor wall-to-wall as much as 10 meters thick (Hill, 1996). Much of this gypsum blanket is now gone due to dissolution by dripping meteoric water, and left the cave system as the water table lowered.

There is a very close, modern analog to this model of sulfuric acid speleogenesis, which has been studied since the mid-1940s (Parker, 1951), decades before the concept was applied to caves. It is called biogenic sulfide corrosion, and occurs in concrete sanitary wastewater pipes and tanks (USEPA, 1992). When the wastewater flow is sluggish and there is air space above it,
SRB thrive in the anaerobic, sulfate-rich water as a biofilm that coats the wall of the submerged portion of the pipe. The produced $\mathrm{H}_{2} \mathrm{~S}$ that volatilizes into the humid air space diffuses into the condensate on the pipe wall. SOB thriving in that water oxidize the $\mathrm{H}_{2} \mathrm{~S}$ through a series of steps via sulfur to produce sulfuric acid. Abiotic oxidation also occurs, but the reaction is slow and proceeds via thiosulfate $\left(\mathrm{S}_{2} \mathrm{O}_{3}\right)($ Okabe and others, 2005). The acid corrodes the pipe wall, most intensely at the crown (where drips accumulate) and just above the water line, by converting the calcium carbonate in the concrete into gypsum rinds. The gypsum is usually dissolved away by high wastewater flow, leaving pitted walls of reduced thickness. Unreacted acid runs down the pipe wall, producing rills.

When this scenario is compared to an active sulfuric acid cave like Cueva de Villa Luz, the similarities seem to outweigh the differences. In both scenarios, sulfuric acid is generated subaerially and biotically by oxidizing elemental sulfur.

\section{CONCLUSIONS}

Not all the caves in the Guadalupe Mountains were formed by spongework enlargement, especially for those caves that developed above and beyond the reaches of tidal mixing, where no mixing corrosion occurred. Based on a comparison of Carlsbad Cavern with active sulfuric acid caves, it appears that the geologic setting must include three features for sulfuric acid hypogene speleogenesis to occur:

1) Pre-existing cavernous porosity (sufficient air space for condensation and air flow) in the carbonate rock to allow sulfuric acid to form above the water table as a vapor and within condensate. In the Guadalupe Mountains, and perhaps in many sulfuric acid caves, this pre-existing porosity appears to have been spongework, not phreatic conduits.

2) Subterranean springs of sulfate-rich groundwater (seawater or brine water) to allow SRB to flourish near the top of the water table and produce $\mathrm{H}_{2} \mathrm{~S}$ as a byproduct.

3) A geothermal heat source to heat the groundwater to cause upwelling, creating an 
environment where meso- and/or thermophilic SRB can thrive, and a thermal gradient between the groundwater and the walls above the water table to promote condensation and an environment for SOB to thrive.

A geologic setting where all three features combine to produce sulfuric acid caves is relatively rare, but includes proximity to a sea or a former sea basin with evaporites. This would explain the common combination of spongework and sulfate-rich groundwater. The relation between petroleum reservoirs and sulfuric acid caves is a shared geologic settingbasins. However, the relation ends there. That minor quantities of oil can migrate up from the basin via fractures and seep into sulfuric acid caves on the edge of the platform is not surprising, but it is not a forgone conclusion that the petroleum is the source of the $\mathrm{H}_{2} \mathrm{~S}$. That $\mathrm{H}_{2} \mathrm{~S}$ is being produced by SRB in connection with high petroleum deposits in the Delaware Basin is not doubted. However, petroleum-derived $\mathrm{H}_{2} \mathrm{~S}_{(\text {aq) }}$ in the brine water would remain undissociated under lithostatic pressure, allowing it to oxidize abiotically to sulfur upon mixing with meteoric water, as is found in the Ochoan evaporites (Davis and Kirkland, 1970), or dissociate as it approaches the water table. Only when $\mathrm{H}_{2} \mathrm{~S}$ is produced near the water table can it be expected to enter air-filled cavities as a gas.

An excellent example of how a sulfuric acid cave can transition from active to relic by the removal of requirements 2 and 3 outlined above can be observed by comparing the difference between Upper and Lower Kane Caves in Big Horn Basin, Wyoming. Upper Kane Cave is believed to be a relic sulfuric acid cave directly above (about 30 meters) and air-connected to Lower Kane Cave, an active sulfuric acid cave (Hose and Macalady, 2006). The reason that Upper Kane Cave is relic is because base level lowered and the thermal, sulfate-bearing stream now runs through Lower Kane Cave. SOB cannot thrive in a dry environment.

Spongework is not a common cave speleogen, so any theory of its origin must take this into account (a single process is more likely than two unrelated processes). Outside of sulfuric acid caves, spongework is believed to be the result of phreatic mixing corrosion at the freshwater/seawater interface of a coastal aquifer. The speleogens that are the product of sulfuric acid dissolution include walls that are pitted and have upward-pointing scallops from convective air currents. The absence of these speleogens and gypsum rinds in the peripheral spongework indicates that it was outside the reaches of sulfuric acid dissolution and is original. Both chemistry and modern analogs indicate that sulfuric acid is not generated subaqueously. Therefore, the pre-existing spongework provided the necessary air space above the water table for sulfuric acid to form subaerially, mostly by SOB. Without the preexisting spongework, sulfuric acid would never have formed. Sulfuric acid forms abiotically from sulfur oxides, so the sulfuric acid equation commonly used, $\mathrm{H}_{2} \mathrm{~S}+2 \mathrm{O}_{2} \rightarrow \mathrm{H}_{2} \mathrm{SO}_{4}$, is actually shorthand for a two to four step process of oxidation, which is greatly enhanced by SOB. The process of sulfuric acid enlargement of preexisting porosity (spongework) only lasted as long as the high heat flow from the Basin and Range crustal thinning and igneous intrusions (about 20-0 ma), which provided a warm, saline water environment for thermophilic SRB to thrive in and produce abundant $\mathrm{H}_{2} \mathrm{~S}$. Perhaps an active sulfuric acid cave like Cueva de Villa Luz is more of a modern analog to the relic caves of the Guadalupe Mountains than initially perceived, the only significant difference being that Guadalupe caves were not resurgent caves.

\section{REFERENCES}

Barker, C.E., and Pawlewicz, M.J., 1987, The effects of igneous intrusions and higher heat flow on the thermal maturity of Leonardian and younger rocks, western Delaware Basin, Texas, in Cromwell, Dave, and Mazzullo, L.J., eds., The Leonardian facies in west Texas and southeast New Mexico and guidebook to the Glass Mountains, West Texas: SEPM-Permian Basin Section, Publication No. 87-27, p. 69-84.

Bogli, Alfred, 1980, Karst hydrology and physical speleology: New York, Springer-Verlag, 284 p.

Bretz, J.H., 1942, Vadose and phreatic features of limestone caverns: Journal of Geology, v. 50, no. 6, p. 675-811. 
Bretz, J.H., 1949, Carlsbad Caverns and other caves of the Guadalupe block, New Mexico: Journal of Geology, v. 57, no. 5, p. 447-463.

Davis, J.B., and Kirkland, D.W., 1970, Native sulfur deposition in the Castile Formation, Culberson County, Texas: Economic Geology, v. 65, p. 107-121.

Galdenzi, Sandro, and Maruoka, Teruyuki, 2003, Gypsum deposits in the Frasassi Caves, central Italy: Journal of Cave and Karst Studies, v. 65, no. 2, p. 111-125.

Hill, C.A., 1996, Geology of the Delaware Basin Guadalupe, Apache, and Glass Mountains, New Mexico and west Texas: SEPM-Permian Basin Section, Publication No. 96-39, 480 p.

Hill, C.A., 2006, Geology of the Guadalupe Mountains: An overview of recent ideas, in Land, Lewis, and others (eds.), Caves and karst of southeastern New Mexico: New Mexico Geological Society, $57^{\text {th }}$ Annual Field Conference, Socorro, September 21-24, 2006, p. 145-150.

Hose, L.D., and Macalady, J.L., 2006, Observations from active sulfidic karst systems: Is the present the key to understanding Guadalupe Mountain speleogenesis?, in Land, Lewis, and others (eds.), Caves and karst of southeastern New Mexico: New Mexico Geological Society, $57^{\text {th }}$ Annual Field Conference, Socorro, September 21-24, 2006, p. 185-194.

Hose, L.D., Palmer, A.N., Palmer, M.V., Northup, D.E., Boston, P.J., and Duchene, H.R., 2000, Microbiology and geochemistry in a hydrogensulphide-rich karst environment: Chemical Geology, v. 169, p. 399-423.

Hose, L.D., and Pisarowicz, J.A., 1999, Cueva de Villa Luz, Tabasco, Mexico: Reconnaissance study of an active sulfur spring cave and ecosystem: Journal of Cave and Karst Studies, v. 61, no. 1, p. 13-21.

Hunt, D.W., Fitchen, W.M, and Kosa, Eduard, 2002, Syndepositional deformation of the Permian Capitan reef carbonate platform, Guadalupe Mountains, New Mexico, USA: Sedimentary Geology, v. 154, p. 80-126.

Kirkland, D.W., 1982, Origin of gypsum deposits in Carlsbad Caverns, New Mexico: New Mexico Geology, v. 4, p. 20-21.

Klimchouk, A.B., Ford, D.C., Palmer, A.N., and Dreybrodt, Wolfgang, (eds.), 2000, Speleogenesis: Evolution of karst aquifers:
Huntsville, Alabama, National Speleological Society, 527 p.

Kosa, Eduard, and Hunt, D.W., 2006, Heterogeneity in fill and properties of karst-modified syndepositional faults and fractures: Upper Permian Capitan platform, New Mexico, USA: Journal of Sedimentary Research, v. 76, p. 131151.

Luther, G.W., III, Findlay, A.J., MacDonald, D.J., Owings, S.H., Hanson, T.E., Beinart, R.A., and Girguis, P.R., 2011, Thermodynamics and kinetics of sulfide oxidation by oxygen: A look at inorganically controlled reactions and biologically mediated processes in the environment: Frontiers in Microbiology, v. 2, 62.

Macalady, J.L., Lyon, E.H., Koffman, Bess, Albertson, L.K., Meyer, Katja, Galdenzi, Sandro, and Mariani, Sandro, 2006, Dominant microbial populations in limestone-corroding stream biofilms, Frasassi Cave system, Italy: Applied and Environmental Microbiology, v. 72, no. 8, p. 5596-5609.

Mylroie, J.E., and Carew, J.L., 1990, The flank margin model for dissolution cave development in carbonate platforms: Earth Surface Processes and Landforms, v. 15, p. 413-424.

Okabe, Satoshi, Ito, Tsukasa, Sugita, Kenichi, and Satoh, Hisashi, 2005, Succession of internal sulfur cycles and sulfur-oxidizing bacteria communities in microaerophilic wastewater biofilms: Applied and Environmental Microbiology, v. 71, no. 5, p. 2520-29.

Palmer, A.N., 1975, The origin of maze caves: National Speleological Society Bulletin, v. 37, p. 56-76.

Palmer, A.N., 1991, Origin and morphology of limestone caves: Geological Society of America Bulletin, v. 103, p. 1-21.

Palmer, A.N., 2005, Passage growth and development, in Culver, David C., and White, William B. (eds.): Encyclopedia of Caves, p. 440-444.

Palmer, A.N., 2006, Support for a sulfuric acid origin for caves in the Guadalupe Mountains, New Mexico, in Land, Lewis, and others (eds.), Caves and karst of southeastern New Mexico: New Mexico Geological Society, $57^{\text {th }}$ Annual Field Conference, Socorro, September 21-24, 2006, p. 195-202.

Palmer, A.N., 2007, Cave geology: Dayton, OH, Cave Books, 454 p. 
Palmer, A.N., and Palmer, M.V., 2000,

Hydrochemical interpretation of cave patterns in the Guadalupe Mountains, New Mexico: Journal of Cave and Karst Studies, v. 62, no. 2, p. 91108.

Palmer, A.N., and Palmer, M.V., 2012, Petrographic and isotopic evidence for late-stage processes in sulfuric acid caves of the Guadalupe Mountains, New Mexico, USA: International Journal of Speleology, v. 41, no. 2, p. 231-250.

Parker, C.D., 1951, Mechanics of corrosion of concrete sewers by hydrogen sulfide: Sewage and Industrial Wastes, v. 23, no. 12, p. 14771485.

Plummer, L.N., 1975, Mixing of sea water with calcium carbonate ground water: Geological Society of America Memoir 142, p. 219-236.

Polyak, V.J., McIntosh, W.C., Guven, N., and Provencio, P., 1998, Age and origin of Carlsbad Caverns and related caves from ${ }^{40} \mathrm{Ar} /{ }^{39} \mathrm{Ar}$ of alunite: Science, v. 279, p. 1919-1922.

Saller, A.H., 1996, Differential compaction and basinward tilting of the prograding Capitan Reef, Permian, west Texas and southeast New Mexico, USA: Sedimentary Geology, v. 101, p. 21-30.

U.S. Environmental Protection Agency (USEPA), 1992, Detection, control, and correction of hydrogen sulfide corrosion in existing wastewater systems: EPA No. 832R92001, 162 p.

U.S. Environmental Protection Agency (USEPA), 2002, Lexicon of cave and karst terminology: http://www.karstwaters.org/files/glossary.pdf.

White, W.B., 1988, Geomorphology and hydrology of karst terrains: New York, Oxford University Press, $464 \mathrm{p}$.

Zhang, Jia-Zhong, and Millero, F.J., 1993, The products from the oxidation of $\mathrm{H}_{2} \mathrm{~S}$ in seawater: Geochimica et Cosmochimica Acta, v. 57, p. 1705-1718. 


\title{
Geologic Framework, Structure, and Hydrogeologic Characteristics of the Knippa Gap Area in Eastern Uvalde and Western Medina Counties, Texas
}

\author{
By Allan K. Clark, Diana E. Pedraza, and Robert R. Morris
}

U.S. Geological Survey, 5563 De Zavala Rd., San Antonio, TX, 78249

\begin{abstract}
The Edwards aquifer is the primary source of potable water for the San Antonio area in south-central Texas. The Knippa Gap area was postulated to channel or restrict flow in the Edwards aquifer in eastern Uvalde County, and its existence was based on a series of numerical simulations of groundwater flow in the aquifer. To better understand the function of the area known as the Knippa Gap as it pertains to its geology and structure, the geologic framework, structure, and hydrogeologic characteristics of the area were evaluated by the U.S. Geological Survey in cooperation with the U.S. Army Corps of Engineers Fort Worth District. The principal structural feature in the San Antonio area is the Balcones Fault Zone, which is the result of Miocene-age faulting. Groundwater flow paths in the Edwards aquifer are influenced by faulting and geologic structure. Some faults act as barriers to groundwater flow where the aquifer is offset by 50 percent or more and result in flow moving parallel to the fault. The effectiveness of a fault as a barrier to flow changes as the amount of fault displacement changes.
\end{abstract}

The structurally complex area of the Balcones Fault Zone contains relay ramps, which form in extensional fault systems to allow for deformation changes along the fault block. In Medina County, the faulting of the Balcones Fault Zone has produced a relay ramp that dips to the southwest from the Edwards aquifer recharge zone and extends westward and below land surface from Seco Creek. In the northern part of the county, groundwater moves downgradient (downdip) to the southwest along this relay ramp towards a structural low (trough). In Uvalde County, groundwater also moves downdip from a structural high known as the Uvalde Salient towards a structural low (trough) to the northeast. These two opposing structural dips result in a subsurface structural low locally referred to as the Knippa Gap. This trough is located in eastern Uvalde County beneath the towns of Knippa and Sabinal. By using data that were compiled and collected for this study and previous studies, a revised map was constructed depicting the geologic framework, structure, and hydrogeologic characteristics of the Knippa Gap area in eastern Uvalde and western Medina Counties, Texas. The map also shows the interpreted structural dip directions and interpreted location of the structural low in the area known as the Knippa Gap.

\section{REFERENCE}

Clark, A.K., Pedraza, D.E., and Morris, R.R., 2013, Geologic framework, structure, and hydrogeologic characteristics of the Knippa Gap area in eastern Uvalde and western Medina Counties, Texas: U.S. Geological Survey Scientific Investigations Report 2013-5149, 35 p., 1 pl., http://pubs.usgs.gov/sir/2013/5149/. 


\title{
A Hypothesis for Carbonate Island Karst Aquifer Evolution from Analysis of Field Observations in Northern Guam, Mariana Islands
}

\author{
By John W. Jenson ${ }^{1}$, Danko Taboroši ${ }^{1}$, Kolja Rotzoll ${ }^{2}$, John E. Mylroie ${ }^{3}$, and Stephen B. \\ Gingerich $^{4}$ \\ ${ }^{1}$ Water \& Environmental Research Institute of the Western Pacific, University of Guam, Mangilao, GU \\ 96923 \\ ${ }^{2}$ Water Resources Research Center, University of Hawaii, Honolulu, HI 96822 \\ ${ }^{3}$ Department of Geosciences, Mississippi State University, Mississippi State, MS 39762 \\ ${ }^{4}$ Pacific Islands Water Science Center, U.S. Geological Survey, Honolulu, HI 96813
}

\begin{abstract}
Field studies of coastal discharge and aquifer properties on northern Guam, an uplifted eogenetic karst plateau, suggest carbonate island karst aquifers undergo profound reorganization of porosity and permeability and develop complex but predictable patterns of hydraulic conductivity, internal transport, and coastal discharge. Discharge features along the coast can be classified into four geomorphic categories: beach seeps and springs, reef seeps and springs, fracture springs, and cave springs. The styles and distribution of discharge among these four categories suggest that in aquifers composed of uplifted geologically young limestone, matrix, fracture, and conduit porosity each play significant but varying roles. Analyses of tidal attenuation in wells across the plateau indicate that hydraulic conductivity near the periphery is two orders of magnitude lower than in the interior: 20-800 meters/day, compared to 2,00090,000 meters/day. We propose a conceptual framework that relates the four categories of coastal discharge to the evolution and reorganization of porosities in the aquifer, and offer a hypothesis for the general distribution of hydraulic conductivity on uplifted carbonate island aquifers, in particular the juxtaposition of high conductivity in the interior against lower conductivity on the periphery: (1) dissolutional enhancement of horizontal hydraulic conductivity in the interior, (2) concurrent reduction of local hydraulic conductivity in the cliffs and steeply inclined rocks on the periphery by case hardening and perhaps other karst processes that promote occlusion of primary porosity on and inland of the rampart, and (3) development of the stronger influence of higher conductivity regional-scale features in the interior relative to the periphery. Complexity is further increased by glacioeustasy and tectonic fluctuations that moved the freshwater lens vertically through the bedrock column and forced reorganization of porosities within horizontal planes at different levels.
\end{abstract}

\section{REFERENCES}

Gingerich, S.B., 2013, The effects of withdrawals and drought on groundwater availability in the northern Guam Lens aquifer, Guam: U.S. Geological Survey Scientific Investigations Report 2013-5216, 76 p., http://dx.doi.org/10.3133/sir20135216.

Rotzoll, Kolja, Gingerich, S.B., Jenson, J.W., and El-Kadi, A.I., 2013, Estimating hydraulic properties from tidal attenuation in the northern Guam Lens aquifer, territory of Guam, USA: Hydrogeology Journal, v. 21, p. 643654, DOI 10.1007/s10040-012-0949-9. 


\title{
Using Borehole and Surface Geophysics to Develop a Conceptual Model of Hydrostratigraphic Layers, Pecos County Region, Texas, 2012
}

\author{
By Jonathan V. Thomas, Johnathan R. Bumgarner, Gregory P. Stanton, Andrew P. \\ Teeple, and Jason D. Payne \\ U.S. Geological Survey, 2775 Altamesa Blvd., Fort Worth, TX 76133
}

\begin{abstract}
Future groundwater availability is a concern in the Pecos County region of west Texas, where the Edwards-Trinity aquifer is an important water resource. The U.S. Geological Survey (USGS), in cooperation with the Middle Pecos Groundwater Conservation District, Pecos County, City of Fort Stockton, Brewster County, and Pecos County Water Control and Improvement District No. 1, developed a conceptual model of the Edwards-Trinity aquifer as part of a multi-phase study of the Pecos County region. Interpreting the hydrostratigraphic layer contacts from historic and newly collected borehole geophysical logs, surface geophysical soundings, and geologic data was a major part of model development. Approximately 200 borehole geophysical logs and 300 well reports, along with 4 timedomain electromagnetic soundings, and 13 audio-magnetotelluric soundings were correlated to determine tops and bases of the aquifer (hydrostratigraphic) layers. Data collected by the USGS during 2009-11 and historical data from 1930-2011 collected by various state and local agencies were used in the model. Previous studies in this region indicate that groundwater flow is largely controlled by collapse structures and associated faulting. Multiple north-south and east-west geologic sections were constructed from hydrostratigraphic surface grids across the Pecos County region to analyze fault zones and local structural features. Updated grids were created to reflect the fault displacement associated with fault zones, in many cases showing units juxtaposed across the fault zone. The resulting hydrostratigraphic grids were used along with geochemistry and hydraulic-property data to develop the conceptual model, which aids in understanding the hydrogeologic framework, geochemistry, and groundwater-flow system. This information will be used to construct a groundwater flow model of the region. Additional information on this study can be found online at http://pubs.usgs.gov/sir/2012/5124/pdf/SIR12-5124.pdf.
\end{abstract}




\section{Perils of a Dissolving State-Florida}

By Clint Kromhout

Florida Geological Survey, Department of Environmental Protection, 903 West Tennessee Street, Tallahassee, Florida 32304

\section{Abstract}

Florida is no stranger to tropical storms or sinkholes, and for many who live in the state their primary worry is focused on the state's annual hurricane season. Sinkholes, however, have become a storm of their own in recent years. In June 2012, Tropical Storm Debby dropped record amounts of rain upon Florida during a time of extended drought, which triggered hundreds of sinkholes that resulted in property damage across a wide swath of the state. Several subsequent well-publicized sinkhole events in Florida, combined with pervasive insurance industry financial troubles, have brought these natural karst features to main stage. The Florida Division of Emergency Management (DEM), a first responder to many of these sinkhole incidents, sought a science-based solution to assessing regional sinkhole vulnerability. In September 2013, the DEM's Mitigation Section contracted with the Florida Geological Survey to produce a statewide map depicting relative vulnerability to sinkhole formation. 


\title{
MODELING KARST AQUIFERS
}

\section{Taking the Mystery Out of Mathematical Model Applications to Karst Aquifers-A Primer}

\author{
By Eve L. Kuniansky \\ U.S. Geological Survey, 1770 Corporate Drive, Suite 500, Norcross, GA 30093
}

\begin{abstract}

\section{INTRODUCTION}

Understanding the nature of karst aquifers, including their management and protection, poses unique challenges. Advances have been made in the development (codes developed in late 1970s through 90s) and use of mathematical model applications (late 1980s to present) to improve the understanding of dual flow processes as well as characterization and management of karst aquifers.
\end{abstract}

Advances in mathematical model applications toward the understanding of the complex flow, characterization, and water-supply management issues for karst aquifers have occurred in recent years. Different types of mathematical models can be applied successfully if appropriate information is available and the problems are adequately identified. The mathematical approaches discussed in this paper are divided into three major categories: 1) distributed parameter models, 2) lumped parameter models, and 3) fitting models. The modeling approaches are described conceptually with examples (but without equations) to help non-mathematicians understand the applications.

Several different types of mathematical models can be applied to problems in complex dual or triple porosity karst aquifers. Depending on the types of data available and the problems that are identified, different mathematical techniques can be applied appropriately. The naming of the types of mathematical models that have been applied has become somewhat confusing because terminology has not been used consistently among all authors. This paper groups the different mathematical approaches into three major categories: 1 ) distributed parameter models, 2) lumped parameter models, and 3) fitting models. The three categories were chosen based on the general mathematical methods applied in the calculations. The modeling approaches are described conceptually with examples (but without equations) to help non-mathematicians understand the applications.

The first category, distributed parameter or deterministic numerical models, includes models derived for physical processes defined by partial differential equations, which are solved numerically. This first category of mathematical models is used to simulate flow in a karst aquifer as inferred from hydrogeologic investigations of all types. The second category, lumped parameter models, is based on mathematical methods that combine a physically based equation (ordinary differential equation) with control theory or operations research techniques (Hillier and Lieberman, 1967; Takahashi and others, 1972; U.S. Department of Agriculture, 1973). This second category has some physical basis, but generally lumps the karst aquifer into large basins and is not meant to simulate details of the flow system. This type of model also is incapable of distinguishing between different system compartments and different flow processes. Many of the hydrogeochemical mixing models used for estimating the average age of water (binary mixing, piston flow, exponential, and dispersion) fall into this category (Maloszewski, 2000; Katz, 2004). The third category, fitting models, refers to mathematical methods that involve either statistical regression, fitting shape functions, statistical transfer functions, or use of pattern recognition functions, such as artificial neural networks to recreate observations (Long and Putnam, 2002, 2007; Hu and others, 2007). There is some overlap in the mathematical methods employed in the categories of lumped parameter models and fitting models, because both categories involve mathematical techniques 
that come from the fields of control theory (sometimes called operations research) or linear systems theory (U.S. Department of Agriculture, 1973).

\section{DISTRIBUTED PARAMETER MODELS}

Distributed parameter models, also called deterministic numerical models, are frequently applied to karst aquifer systems (Teutsch and Sauter, 1998; Scanlon and others, 2003). Distributed parameter models are process oriented: equation(s) are derived that include the important physical process (es) that result in a partial differential equation(s) that can be solved numerically. In general, the physical processes involved in the flow of water through an aquifer are simplified in order to develop an equation that can be solved by a numerical method, such as finite element or finite difference. Because distributed parameter models require dividing (discretizing) the system into smaller volumes, such as finite-difference cells or finite elements, representation of the karst aquifer is greatly simplified, but the physical parameters, such as storage, hydraulic conductivity, or transmissivity are distributed spatially and allowed to vary in each cell or element.

Several types of deterministic models have been applied to karst aquifers (fig. 1). The simplest method is called the single continuum porous equivalent, potential flow,

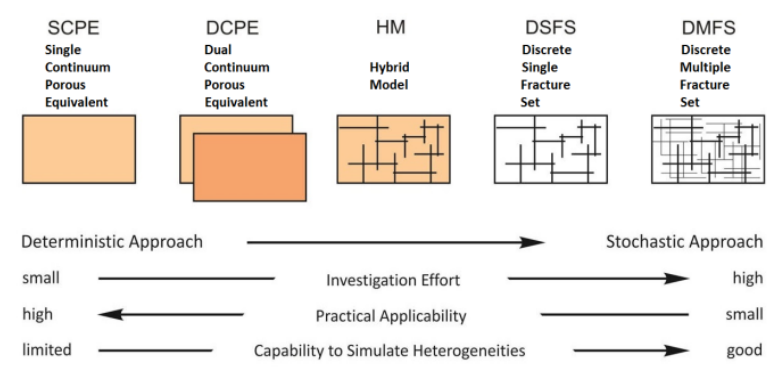

Figure 1. Approaches to karst modeling with deterministic numerical models and some stochastic methods for developing fracture networks, where the networks are simulated with flow equations for pipes or fractures (from Teutsch and Sauter, 1998).

heterogeneous continuum, distributed parameter, or smeared conduit approach. Another method is called the dual continuum porous equivalent approach (DCPE), which links two flow regimes at each cell or element with an exchange term. The hybrid model (HM) couples a single continuum porous equivalent model with a discrete one-dimensional pipe network. The last two examples are the discrete single-fracture set (DSFS) and the discrete multiple fracture set (DMFS) models, which may involve the stochastic generation of fracture networks; however, the networks once generated are simulated with equations for pipe or fracture flow. Each approach has advantages and disadvantages, described below (fig. 1).

\section{Single Continuum or Porous Equivalent Models}

A single continuum porous equivalent approach using the groundwater flow equation based on laminar flow is the simplest to apply. Generally, this approach has been applied for regional flow problems because the investigation scale is much greater than the scale of the heterogeneities (conduits), and for waterresources investigations in which the models can be calibrated to flow and head information and only water budgets are desired (Kuniansky and Holligan, 1994; Davis, 1996; Teutsch and Sauter, 1998; Kuniansky and others, 2001; Svensson, 2001; Scanlon and others, 2003; Davis and Katz, 2007; Davis and others, 2010). In general, this approach can simulate transient springflow for monthly or annual averages, but may not reproduce detailed storm event hydrographs as well as other model types as a result of the onset of turbulence during storms (Hill and others, 2010; Kuniansky and others, 2011; Gallegos and others, 2013; Saller and others, 2013). However, simulations of advective transport using a single continuum model are frequently performed and are able to match geochemical age estimates and tracer-test times of travel when using a porosity of less than 5 percent (Knochenmus and Robinson, 1996; Kuniansky and others, 2001; Renken and others, 2005; Davis and others, 2010). The flow in these studies was mainly determined by the model cell hydraulic conductivity and total model layer thickness. In some cases where conduit locations are known, the finite-difference cells with conduits are assigned much greater hydraulicconductivity values than surrounding cells and have been successful in reproducing transient spring discharge and matching tracer tests in part of the Floridan aquifer system (Davis and others, 
2010). A similar attempt was not successful within the Edwards aquifer system (Lindgren and others, 2009).

Both finite difference and finite element methods have been widely applied. Finite element methods allow for greater variation in element size, and streams, wells, and springs can be more accurately located. Finite elements readily accommodate sites where geologic structure results in preferential directions of dissolution that can create anisotropy varying in direction over the aquifer domain (Kuniansky and Lowther, 1993). However, developing model datasets for a finite-element model is more complex than a block-centered finitedifference scheme, and a graphic-user interface (GUI) is essential. As computer speeds have increased, so has the simulation speed of larger finite-difference model grids with smaller grid spacing. Additionally, packages such as the horizontal flow barrier package for MODFLOW (Hsieh and Freckleton, 1993) have been used to help incorporate geologic structure that reflects anisotropy rather than direct incorporation of anisotropy into the flow equation (Lindgren and others, 2004). The new code for MODFLOW that allows unstructured grids has many of the advantages of finite elements, but also requires a sophisticated GUI (Panday and others, 2013).

Most single-continuum applications described above involve simulating laminar flow. The most commonly used computer code is MODFLOW (http://water.usgs.gov/ogw/modflow/). However, turbulent flow for large-pore aquifers, where flow becomes turbulent at low Reynolds numbers, has been incorporated as an option into MODFLOW-2005, called the conduit flow process mode 2 (MODFLOW-CFP mode 2; Shoemaker and others, 2008; Kuniansky and others, 2008). Reimann and others (2011a) derived a general form for incorporation of turbulence into MODFLOW-CFP mode 2, which can simulate turbulence for porous media or conduits, employing a single continuum approach.

\section{Dual Continuum or Porous Equivalent Models}

Dual continuum models link two single continuum models via a hydraulic headdependent flux term between each model cell. One continuum has high hydraulic conductivity and low storage, representing conduits, and the other continuum has low hydraulic conductivity and high storage, representing the primary porosity of the rock matrix. The main advantage of the dual continuum approach is that the detailed geometry of the conduits is not required (Teutsch, 1993; Sauter, 1993; Lang, 1995), and dual continuum models have been applied successfully when the geometry of conduits is not known (Teutsch and Sauter, 1991; Teutsch, 1993; Sauter, 1993; Teutsch and Sauter, 1998; Painter and others, 2007). Dual continuum models can simulate rapid variations in discharge and head change following recharge events and can accommodate the variable contributions of conduit and rock matrix flow with time. The data demand of the model is relatively modest and the parameterization effort is manageable for general field studies. The dual continuum model, however, is not always capable of simulating transport processes on a small scale (Mohrlok, 1996).

\section{Hybrid Models}

A hybrid model is the coupling of a single continuum model with a discrete conduit or pipe network model (Kiraly, 1998; Teutsch and Sauter, 1998). The approach allows the integration of detailed information about the conduits in areas where the geometry of the conduits may be known, thus providing a more physically representative model. They are considered hybrid models because they link a single continuum model for groundwater flow in 3 dimensions with a 1-dimensional pipe network model. The two models exchange water via hydraulic head-dependent flux terms and iterate calculations between the two models until both converge, similar to the dual continuum model.

The 2008 distribution of the conduit flow process (CFP) for MODFLOW-2005 (Harbaugh, 2005; Shoemaker and others, 2008) takes the hybrid modeling approach developed in the Conduit Aquifer Void Evolution (CAVE) code 
(Clemens and others, 1996; Bauer and others, 2003; Liedl and others, 2003) from a research code to a tool that can be used by a wider group of practitioners. The main advantage of this modeling approach is that it allows simulation of the high transport velocities observed in karst systems, while continuing to represent the presence of a lower hydraulic conductivity matrix, representing the storage component of the karst aquifer. Limitations of this approach are the lack of geometric data for the conduit system (i.e., effective properties have to be assumed). The first release of CFP has limitations in that the pipe network is intended for full pipes (flow controlled by difference in pressure gradient - no free surface) and does not account for free surface flow (open channel flow-flow is under atmospheric pressure and flow is dominated by gravity.)

Several models originally intended for surface-water systems have been applied to karst aquifers. The Storm Water Management Model (SWMM) (Metcalf and Eddy Inc., 1971), designed for simulation of sewer systems, was applied by Peterson and Wicks (2006) to simulate conduits, but no interchange with the rock matrix was simulated. The MODBRANCH code (Swain and Wexler, 1996) was modified for simulation of karst systems by Zhang and Lerner (2000). MODBRANCH was originally developed by coupling a 1-dimensional freesurface open channel flow model with the top layer of a 3-dimensional groundwater flow model for simulation of groundwater/surfacewater interactions. Reimann and others (2011b) developed the ModBraC version of a hybrid model that couples the single continuum model with a pipe network model capable of simulating storage in the conduit system, including full flowing pipes as well as cave streams in the conduits. An accurate representation of conduit storage is essential in order to be able to simulate the lag time between discharge changes and the transport signal (for example, temperature or conductivity) after recharge events.

\section{Discrete Single and Multiple Fracture Network Models}

The discrete fracture approach has been proposed for problems where transient solutetransport responses are desired for a system dominated by conduits (Adams and Parkin, 2002). Knowledge of the fracture network geometry, however, is required for this model. Generally, there are limited data for mapping the fracture network(s); therefore, stochastic methods are often used to generate the single- or multiple-fracture network for deterministic numerical simulations of flow. The disadvantages of discrete multiple fracture networks are the requirements of detailed knowledge of a fracture network at multiple scales and the application of computationally intensive codes that have long computer simulation time and memory requirements (Lang, 1995). Application of this approach to field scale problems is not common, and no examples can be provided.

\section{Application of Deterministic Numerical Models - Example Comparisons of Single Continuum and Hybrid Models}

The karst drainage system of the Wakulla Springs-Leon Sinks, Florida, submerged conduit system is moderately well characterized as a result of pioneering work accomplished over the past 20 years by cave divers of the Global Underwater Explorers as part of their Woodville Karst Plain Project (WKPP). The Woodville karst plain containing the Wakulla Springs-Leon Sinks system covers an area of $450 \mathrm{mi}^{2}$. Wakulla Springs is one of the largest first magnitude springs in Florida with an average flow of approximately $400 \mathrm{ft}^{3} / \mathrm{s}$ and issues from a large opening forming the headwaters of the Wakulla River at Edward Ball Wakulla Springs State Park, Florida.

The WKPP maps served as the basis for three model approaches used for simulation of the groundwater-conduit system: (1) single continuum laminar flow only (equivalent porous media approach documented in Davis and others, 2010), (2) a hybrid model that consists of a single continuum model coupled to a 1dimensional pipe-flow network capable of both turbulent and laminar flow (Gallegos and others, 
2013), which is an evaluation of the CFP mode 1 (Shoemaker and others, 2008), and (3) simulated turbulence within the model layer with large hydraulic-conductivity values assigned to cells with conduits using the single continuum model (Davis and others, 2010; Kuniansky and others, 2011), which is an application of CFP mode 2 (Shoemaker and others, 2008, with modification to mode 2 documented in Reimann and others, 2011a). Large hydraulic-conductivity values were assigned to cells that represent mapped conduits (fig. 2) in approaches 1 and 3. For the hybrid model, the single continuum model of Davis and others (2010) was modified by removing the large hydraulic-conductivity cells and replacing them with a pipe network using MODFLOW-CFP mode 1 (Shoemaker and others, 2008) and recalibrated to a steady-state average condition (Gallegos and others, 2013).

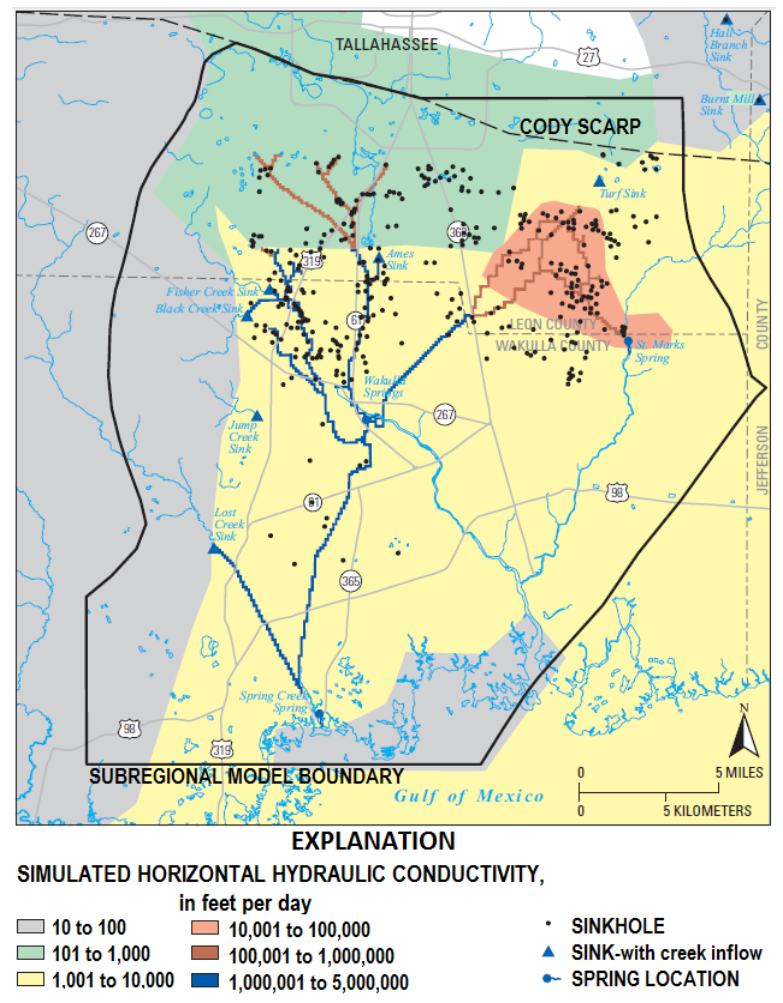

Figure 2. Simulated hydraulic conductivity in model layer 2 with large hydraulic conductivity located at mapped submerged conduits (modified from Davis and others, 2010, fig. 27).

The field applications of MODFLOW-2005 (Harbaugh, 2005) and the CFP (Shoemaker and others, 2008) examined spring discharge under various time discretization and flow conditions.
Model approach 1, the subregional model of Davis and others (2010), was a single continuum transient simulation from January 1, 1966, when spray field (irrigation using treated wastewater as part of municipal wastewater treatment processing) operations began, through 2018, when effects of system upgrades will occur. The stress periods were mostly annual. Calibration data for water levels and spring discharge were available for November 1991, and May to early June 2006. Additional hydrologic information was provided by tracer tests conducted in 2006 and 2007 by Hazlett-Kincaid, Inc. (listed in Davis and others, 2010). The hybrid model (approach 2) was calibrated to steady-state conditions for the same calibration datasets as in approach 1 (Gallegos and others, 2013). The third approach, single continuum with turbulence turned on for layer 2, yielded almost identical heads and flows as in Davis and others (2010) for the original monthly to annual average transient simulation. All three model approaches simulated observed average spring discharge at Wakulla and Spring Creek Springs within 10 percent, and head residuals were within the calibration criteria of plus or minus 5 feet. Thus, for average spring discharge and tracer test time of travel, the models produce similar results and all are considered acceptable calibrations (Davis and others, 2010; Kuniansky and others, 2011; Gallegos and others, 2013).

To observe differences between the single continuum and hybrid model approaches, a transient period with daily spring-flow observations and a storm event (rising and falling springflow, no recalibration) was simulated (Kuniansky and others, 2011; Gallegos and others, 2013). For the 52-day storm event, which was simulated with daily time steps, none of the models simulated the observed peak discharge accurately (within 10 percent of observed) (fig. 3). The shape of the storm hydrograph for Wakulla Springs is best matched by the single continuum with turbulence (approach 3, labeled CFP mode 2 in Reimann and others (2011a), fig. 3), and the peak discharge at about day 15 is matched within 10 percent; however, neither approach 1 (labeled MODFLOW, fig. 3) nor approach 2 (labeled CFP mode 1 hybrid, fig. 3) matched 
peak discharge within 30 percent. If the total volumes of measured and simulated discharge for the 52-day period at Wakulla Springs are compared, approach 1 matched observed within 23 percent, approach 2 within 16 percent and approach 3 within 0.01 percent of total volume of discharge under the 52-day hydrograph.

Model 1 overestimated and model 2 underestimated peak discharge at Wakulla Springs. The computation time required by the hybrid model approach 2 (over 72 hours on a personal computer) was more than 100 times longer than the time required for the single continuum approaches 1 and 3 . This test using hybrid models is perhaps the largest ever undertaken, with more than 1,000 pipes and nodes simulated. The hybrid approach requires that two models are iteratively solved until both converge for each 1-day stress period, resulting in very slow convergence. The greater than $72-$ hour simulation time precludes using parameter estimation to improve model fit for the hybrid model and thus, no attempt was made to recalibrate all three models to both annual or monthly average and the daily storm hydrographs (Kuniansky and others, 2011).

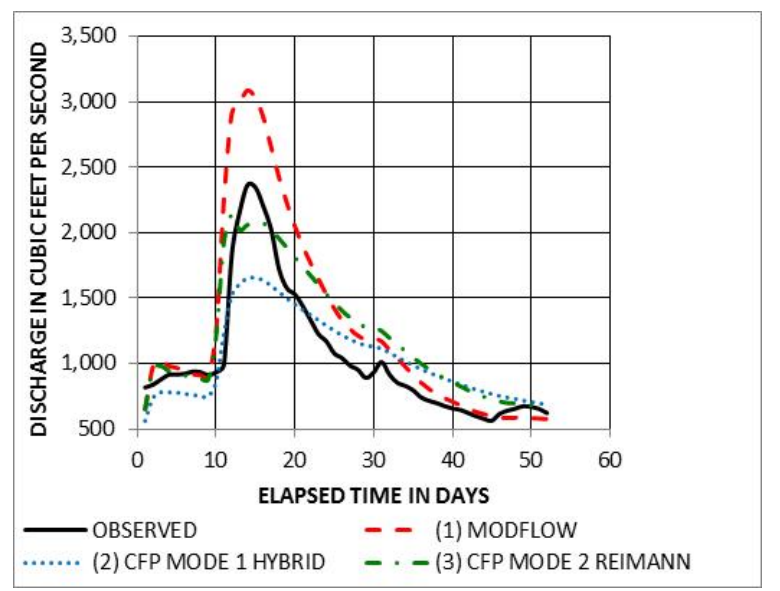

Figure 3. Simulated and observed springflow at Wakulla Springs (modified from Gallegos and others, 2013).

A recent study (Hill and others, 2010), comparing the hybrid model approach with the single continuum model approach for two other spring systems in Florida concluded that the hybrid model more closely simulated observed transient spring discharge. Another recent study (Saller and others, 2013) converted a single continuum model to a hybrid model for a watershed in the Madison aquifer in South Dakota and found that although the hybrid model matched observation well heads better, both models simulated spring discharge accurately. The Wakulla Springs example indicates that, for simulation of average conditions, none of the three model approaches is distinctly better (hybrid model calibrated with steady-state). For the simulation of a transient 52-day storm hydrograph, the single continuum with turbulence model (approach 3) matched peak spring discharge within 10 percent at Wakulla Springs, and the hybrid model (approach 2) matched the total volume of springflow. Improved calibration with parameter estimation techniques was not possible for the hybrid model approach as a result of the long simulation time. Thus, it is unclear if the extra effort required to use a hybrid model, both in data preparation and computation time, is justified for large submerged conduit networks (over 100 pipes and nodes in Kuniansky and others, 2011). The change in temporal discretization appeared to result in the need for recalibration of the models for storm events if the desired accuracy between the model simulation and observed data was 10 percent or less. However, as computer speeds increase, it likely will be feasible to fully calibrate the hybrid models using parameter estimation, resulting in more physically realistic models. An additional test of model capabilities could be comparison of residence times of rapid (event) flow components or slow flow matrix components, derived from use of geochemical mixing models with hydrograph separation techniques given time series datasets of chemistry and flow information. Unfortunately, no such data were available at the time of publication.

\section{LUMPED PARAMETER MODELS}

The control theory approach has been successfully applied to simulate karst aquifers using mathematical methods for solving sets of ordinary differential equations, as for example, filling and mixing of water in a tank or a network of tanks. Coefficients (or lumped parameters) for each tank are developed by calibrating a system of equations (Wanakule and Anaya, 1993; Barret and Charbeneau, 1997). 
Data preparation for lumped parameter models is simpler than that used in deterministic numerical models, and computational times are faster. However, detailed representation of the aquifer is not possible using this approach. Groundwater withdrawals and recharge are summed together for each tank, which represents a geographic area (or spring basin), rather than being placed at actual locations. In addition, withdrawals and recharge may be used as input to simulate spring discharge. This method may be adequate for providing gross estimates of the effects of hypothetical pumpage and recharge rates on spring discharge as well as for providing better estimates of recharge given natural discharge and pumpage. Mathematical filters can be applied to some of the input data, such as development of filters to distribute the annual basin recharge to each month, to gain a better fit of observed versus simulated spring discharge (Dreiss, 1982; Wanakule and Anaya, 1993).

\section{Application of Lumped Parameter Models}

The lumped parameter modeling method is demonstrated in a simulation of springflow at Comal and San Marcos Springs, Texas. The model input and calibration data were based on annual estimates of recharge and pumpage in nine surface-water basins and an index water level in each basin of the Edwards aquifer (Wanakule and Anaya, 1993). The lumped parameter mathematical relation was developed much like a statistical regression model where recharge and pumpage in each lumped parameter block (conceptually, these are nine interconnected tanks as described above) were treated as input to a set of linked tanks that transport water to the major springs. The mathematical description of each tank was formulated with an ordinary differential equation. Figure 4 shows the Edwards aquifer and catchment area and how the tanks are arranged. Surface runoff from the catchment area infiltrates the Edwards aquifer across its outcrop area. Wanakule and Anaya (1993) used the recharge and pumpage data as inputs to the system. They developed filters to disaggregate the annual estimates of recharge into monthly estimates using streamgage data and annual recharge estimates. Additionally, the monthly pumpage by county was reapportioned to each watershed (Wanakule and Anaya, 1993). These values were then matched to monthly groundwater levels in each basin and to the historical spring discharge at Comal and San Marcos Springs by calibrating storage and transmissivity parameters for each tank. The filtering methods for the disaggregation of recharge fall into category 3 (fitting models), which includes time series techniques.

Wanakule and Anaya (1993) were successful in refining estimates of monthly recharge and pumpage for each basin and simulating the spring discharge at Comal and San Marcos Springs (fig. 4c) along with water levels in each basin (not shown herein, refer to Wanakule and Anaya, 1993).

Schulman and others (1995) developed equations for stochastically generating recharge for the watershed basins (generated recharge has the same statistical properties as the historical data--recharge estimates available since 1934.) Endangered species at the springs are at issue, and the courts have required minimum discharges to be maintained at both springs. Groundwater use frequently is restricted during the summer months even as the population continues to grow. Thus, water-resources planners recognize that water may need to be imported to maintain discharge at the springs. Because of its computational speed and simplicity, the calibrated lumped parameter model of Wanakule and Anaya (1993), combined with the generated recharge scenarios, were used in an attempt to screen water-supply options for the Edwards aquifer (Watkins and McKinney, 1999). 

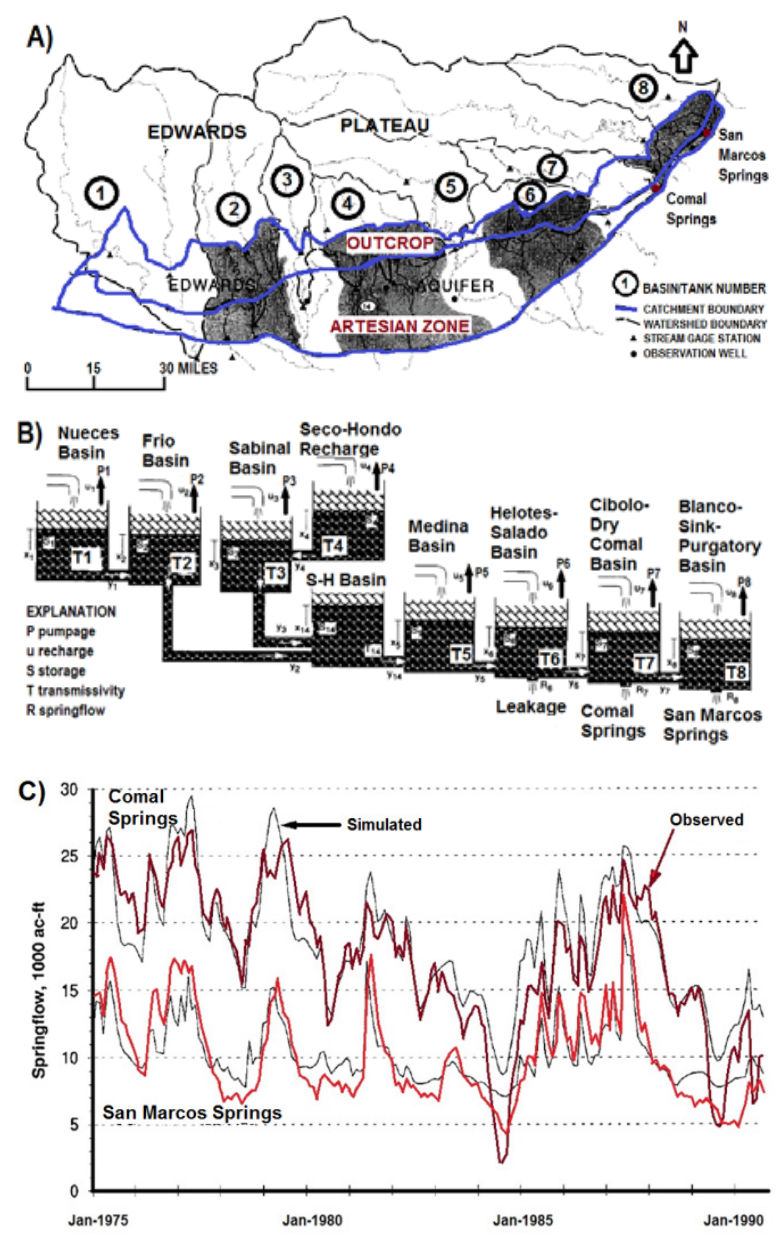

Figure 4. A) Map of the Edwards aquifer and its recharge area, B) Schematic diagram of the lumped parameter model, and C) Comparison of observed and simulated spring discharge (modified from Wanakule and Anaya, 1993).

\section{FITTING MODELS}

Fitting or statistical models have long been used in the field of hydrology. For this discussion, statistical models involve the matching of field data to either a statistical distribution or the development of a single- or multiple-linear regression equation.

Additionally, the broad category includes other forms of linear systems modeling in which the karst aquifer is treated as a filter, and complex mathematical functions (linear kernels) are used to process inputs like recharge and pumpage to generate an output of springflow. The simplest application of linear systems in hydrology has been in rainfall-runoff models that employ what is called the unit hydrograph method (Sherman, 1932). These and similar techniques have recently been applied to karst aquifers (Neuman and de Marsily, 1976; Dreiss, 1982; Wicks and Hoke, 2000). To some extent, these are considered "black box" methods because detailed knowledge about the physical system (locations of conduits, transmissivity, or storage properties) is not required. These methods have advantages and disadvantages that are similar to the lumped parameter models. In fact, statistical models are similar to the lumped parameter approach described earlier, except that they lack any physically-based differential equation to describe the physical aquifer. Instead, complex mathematical functions sometimes based on statistical or probability distributions are used as transfer functions, with time offsets and shape terms used to take an input(s) and create an output (response) that mimics the desired output (response) signal. Another fitting model would be the application of artificial neural networks, a form of pattern recognition, to karst aquifers ( $\mathrm{Hu}$ and others, 2007; Trichakis and others, 2009). A physical understanding of how the karst aquifer system works is required to select an appropriate input, such as recharge and pumpage that is physically related to the output, such as springflow or water level.

Simple regression analysis has been used to predict spring discharge from the water level of a nearby well by developing a linear regression equation using historical data. This technique has also been used for tidally affected springs by developing a multiple linear regression using both water levels at a nearby well and stage data to estimate spring discharge (Wanakule, 1988; Knochenmus and Yobbi, 2001). Development of the regressions requires numerous discharge measurements over the full range of conditions anticipated, but does not involve time-series analysis.

More complex auto-correlation analysis has been used with time-series data to predict springflow from precipitation data (Eisenlohr and others, 1997). Time-series analysis has also been used with isotope data to estimate travel times and the diffuse versus conduit flow nature of karst aquifers as demonstrated with the following case study. 
The advantage of fitting models is that they are easy to apply and to calibrate. The disadvantage is that these models are specific to the respective catchment, and model results are highly uncertain if prediction simulations require input or output variables that exceed those of the historic calibration period.

\section{Application of Fitting Model}

Stable-isotope samples were collected at about 6-week intervals over a 6-year period at a streamflow-loss zone that recharges the karstic Madison aquifer in South Dakota and at a nearby well located close to or within a main groundwater flow path (fig. 5a) (Long and Putnam, 2002, 2007). Time-series analysis of the isotope data indicates that the well responds rapidly to recharge from a sinking stream during wet periods. The hydraulic connection between the stream's loss zone and the well primarily results from flow along conduits. During dry periods when streamflow is low, isotopic values in the well samples primarily were influenced by aquifer-matrix water that has been in storage for many months or years.

Data were analyzed by correlation and linear-systems analysis for a 34-month period of high recharge. Figure $5 b$ shows the original data that were used to develop the model. Figure 5c shows the final model and the log-normal distribution used as the transfer function for estimating the oxygen-18 isotope value in the spring discharge from the streamflow concentration as the input data.

The stable-isotope and water-level datasets correlate most closely when the data from the losing stream reach and the well are lagged 22 days, which may approximate the travel time from the loss zone to the well. Linear-systems analysis results in an estimated travel time to the well of about 15 days and a system memory of 2 to 3 years, resulting from diffuse matrix flow. Based on these analyses, the conduit-flow velocity was estimated at 380 to 800 feet/day (120 to 240 meters/day). A log-normal distribution approximates the distribution of travel times of a plume for conduit flow.

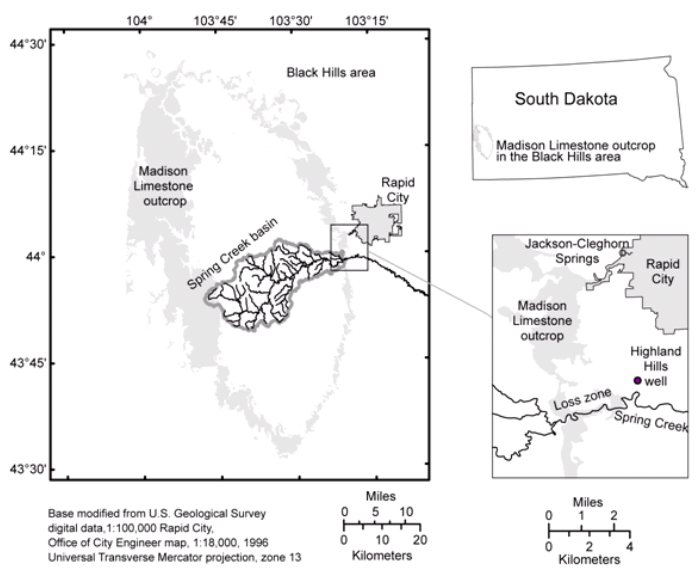

A) Location of the study area.

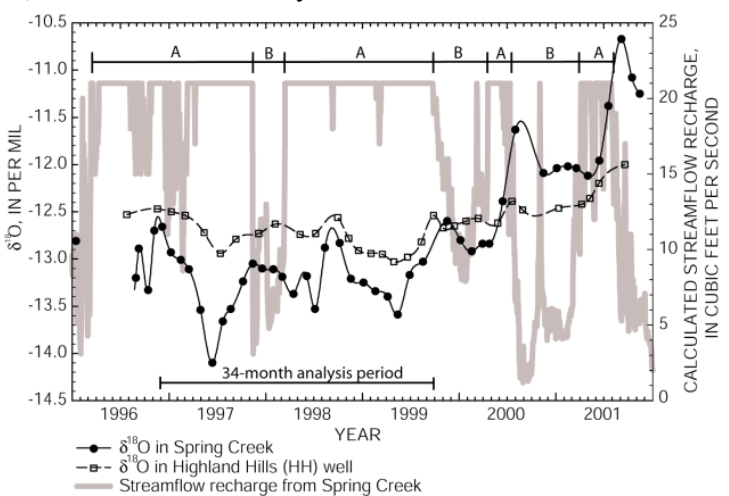

B) $\delta^{18} \mathrm{O}$ data and streamflow recharge to the Madison aquifer from Spring Creek for 1996 through 2001. The curved line through the $\delta^{18} \mathrm{O}$ data points was interpolated by a cubic spline. The A sections indicate periods of nearmaximum recharge, whereas B sections indicate periods of lower recharge. The streamflow recharge has a maximum estimated rate of $21 \mathrm{ft}^{3} / \mathrm{s}$ (Hortness and Driscoll, 1998).

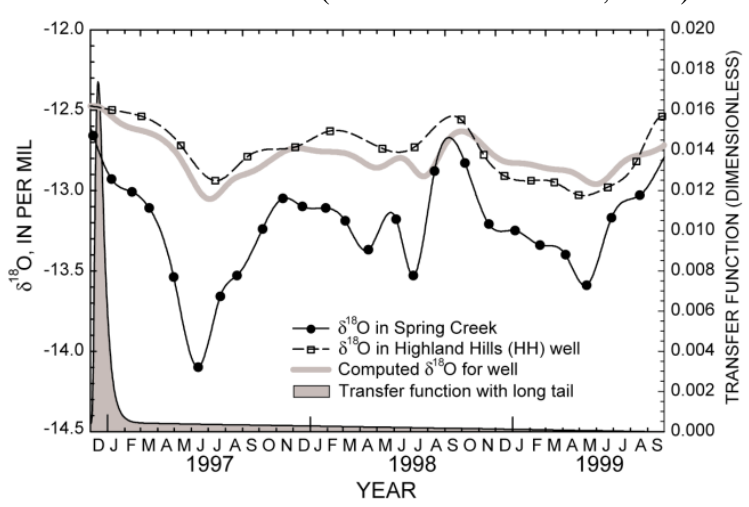

C) Results of linear-systems analysis including the computed $\delta^{18} \mathrm{O}$ data for the sampled well and the transfer function used in the analysis. The curved line through the $\delta^{18} \mathrm{O}$ data points was interpolated by a cubic spline.

Figure 5. Statistical regression model of stable isotope values for springs in the Madison Limestone aquifer. A) Location of study area, B) Isotope and streamflow data, and C) Linear-systems analysis model (from Long and Putnam, 2002). 


\section{CONCLUSIONS}

The mathematical methods for simulation of karst aquifers are well developed. All of the methods require an understanding of each karst aquifer and its unique hydrogeologic setting.

The main difficulty in application of the methods relates to the difficulty of mapping the conduit networks, or having high-quality datasets to calibrate the models. Advances in geophysics, tracer testing, geochemistry, cave exploration, streamflow measurement, and recharge estimation will further improve application of the mathematical models.

\section{REFERENCES}

Adams, R., and Parkin, G., 2002, Development of a surface-groundwater-pipe network model for the sustainable management of karstic groundwater: Berlin, Environmental Geology, v. 42, no. 5, p. 513-517.

Barrett, M. E., and Charbeneau, R. J., 1997, A parsimonious model for simulating flow in a karst aquifer: Journal of Hydrology, v. 196, no. 1-4, p. 47-65.

Bauer, Sebastian, Liedl, Rudolf, and Sauter, Martin, 2003, Modeling of karst aquifer genesis: Influence of exchange flow: Water Resources Research, v. 39, no. 10, 1285 p.

Clemens, Torsten, Hückinghaus, Dirk, Sauter, Martin, Liedl, Rudolf, and Teutsch, Georg, 1996, A combined continuum and discrete network reactive transport model for the simulation of karst development, in Proceedings of the ModelCARE 96 Conference, Golden, Colorado, September 1996, International Association of Hydrological Sciences Publication 237, p. 309318.

Davis, J.H., 1996, Hydrogeologic investigation and simulation of ground-water flow in the Upper Floridan aquifer of north-central Florida and delineation of contributing areas for selected City of Tallahassee, Florida, water-supply wells: U.S. Geological Survey Water-Resources Investigations Report 95-4296, 55 p.

Davis, J.H., and Katz, B.G., 2007, Hydrogeologic investigation, water chemistry analysis, and model delineation of contributing areas for City of Tallahassee public-supply wells, Tallahassee, Florida: U.S. Geological Survey Scientific Investigations Report 2007-5070, 67 p.
Davis, J.H., Katz, B.G., and Griffin, D.W., 2010, Nitrate-N movement in groundwater from the land application of treated municipal wastewater and other sources in the Wakulla Springs springshed, Leon and Wakulla Counties, Florida, 1966-2018: U.S. Geological Survey Scientific Investigations Report 2010-5099, 90 p.

Dreiss, S.J., 1982, Linear kernels for karst aquifers: Water Resources Research, v. 18, no. 4, p. 865876.

Eisenlohr, Laurent, Kiraly, Laszlo, Bouzelboudjen, Mahmoud, and Rossier, Yvan, 1997, Numerical simulation as a tool for checking the interpretation of karst spring hydrographs: Journal of Hydrology, v. 193: p. 306-315.

Gallegos, J.J., Hu, B.X., and Davis, Hal, 2013, Simulating flow in karst aquifers at laboratory and sub-regional scales using MODFLOW-CFP: Hydrogeology Journal, v. 21: p. 1749-1760.

Harbaugh, A.W., 2005, MODFLOW-2005, the U.S. Geological Survey modular ground-water model-The ground-water flow process: U.S. Geological Survey Techniques and Methods 6A16, variously paginated.

Hill, M.E., Stewart, M.T., and Martin, A., 2010, Evaluation of the MODFLOW-2005 Conduit Flow Process: Groundwater, v. 48, no. 4, p. 549559. doi: 10.1111/j.1745-6584.2009.00673.X

Hillier, F.S., and Lieberman, G.J., 1967, Introduction to operations research: Holden-Day Series in Industrial Engineering and Management Science, San Francisco, 639 p.

Hortness, J.E., and Driscoll, D.G., 1998, Streamflow losses in the Black Hills of western South Dakota: U.S. Geological Survey Water-Resources Investigations Report 98-4116, 99 p.

Hsieh, P.A., and Freckleton, J.R., 1993, Documentation of a computer program to simulate horizontal flow barriers using the U.S. Geological Survey's modular three-dimensional finite-difference ground-water flow model: U.S. Geological Survey Open-File Report 92-477, $32 \mathrm{p}$.

Hu, Caihong, Hao, Yonghong, Yeh, T-C.J. Pang, Bo, and $\mathrm{Wu}$, Zening, 2007, Simulation of spring flows from a karst aquifer with an artificial neural network: Hydrological Processes v. 22, issue 5, p. 596-604. 
Katz, B.G., 2004, Sources of nitrate contamination and age of water in large karstic springs of Florida: Environmental Geology, v. 46, p. 689706, doi 10.1007/s00254-004-1061-9.

Kiraly, L., 1998, Modelling karst aquifers by the combined discrete channel and continuum approach: Bulletin d'Hydrogeologie, v. 16, p. 7798.

Knochenmus, L.A., and Robinson, J.L., 1996, Descriptions of anisotropy and heterogeneity and their effect on ground-water flow and areas of contribution to public supply wells in a karst carbonate aquifer system: U.S. Geological Survey Water-Supply Paper 2475, 47 p.

Knochenmus, L.A. and Yobbi, D.A., 2001, Hydrology of the coastal springs ground-water basin and adjacent parts of Pasco, Hernando, and Citrus Counties, Florida: U.S. Geological Survey Water-Resources Investigations Report 20014230, 88 p.

Kuniansky, E.L., Fahlquist, Lynne, and Ardis, A.F., 2001, Travel times along selected flow paths of the Edwards aquifer, central Texas, in Kuniansky, E.L., ed., U.S. Geological Survey Karst Interest Group Proceedings, St. Petersburg, Florida, February 13-16, 2001: U.S. Geological Survey Water-Resources Investigations Report 01-4011, p. 69-77.

Kuniansky, E.L., Gallegos, J.J., and Davis, J.H., 2011, Comparison of three model approaches for spring simulation, Woodville karst plain, Florida, in Kuniansky, E.L., ed., U.S. Geological Survey Karst Interest Group Proceedings, Fayetteville, Arkansas, April 26-29, 2011: U.S. Geological Survey Scientific Investigations Report 20115031, p. 169-170.

Kuniansky, E.L., Halford, K.J., and Shoemaker, W.B., 2008, Permeameter data verify new turbulence process for MODFLOW: Groundwater v. 46 , no. 5, p. 768-771.

Kuniansky, E.L., and Holligan, K.Q., 1994, Simulations of flow in the Edwards-Trinity aquifer system and contiguous hydraulically connected units, west-central Texas: U.S. Geological Survey Water-Resources Investigations Report 93-4039, 40 p.

Kuniansky, E.L., and Lowther, R.A., 1993, Finiteelement mesh generation from mappable features: International Journal of Geographical Information Systems, v. 7, no. 5, p. 395-405.
Lang, U., 1995, Simulation regionaler strömungsUnd transportvorgänge in karstaquiferen mit hilfe des doppelkontinuumansatzes: Stuttgart, Germany, Methodenent wicklung und parameterstudie: Ph.D. dissertation, Institut für Wasserbau, Universität Stuttgart.

Liedl, R., Sauter, M., Hückinghaus D., Clemens T., and Teutsch, G., 2003, Simulation of the development of karst aquifers using a coupled continuum pipe flow model: Water Resources Research, v. 39, no. 1, p. 1057, doi:10.1029/2001WR001206.

Lindgren, R.J., Dutton, A.R., Hovorka, S.D., Worthington, S.R.H., and Painter, Scott, 2004, Conceptualization and simulation of the Edwards aquifer, San Antonio region, Texas: U.S. Geological Survey Scientific Investigations Report 2004-5277, 143 p.

Lindgren, R.J., Taylor, C.J., and Houston, N.A., 2009, Description and evaluation of numerical groundwater flow models for the Edwards aquifer, south-central Texas: U.S. Geological Survey Scientific Investigations Report 20095183, 25 p.

Long, A.J., and Putnam, L.D., 2002, Evaluating travel times and transient mixing in a karst aquifer using time-series analysis of stable isotope data, in Kuniansky, E.L., ed., U.S. Geological Survey Karst Interest Group Proceedings, Shepherdstown, West Virginia, August 20-22, 2002: U.S. Geological Survey Water-Resources Investigations Report 02-4174, p. 66-73.

Long, A.J., and Putnam, L.D., 2007, Characterization of ground-water flow and water quality for the Madison and Minnelusa aquifers in northern Lawrence County, South Dakota: U.S. Geological Survey Scientific Investigations Report 20075001, $62 \mathrm{p}$

Maloszewski, Piotr, 2000, Lumped-parameter models as a tool for determining the hydrological parameters of some groundwater systems based on isotope data:. Tracers and Modelling in Hydrogeology, Proceedings of the TraM'2000 Conference, Liège, Belgium, May 2000): International Association of Hydrological Sciences Publication 262, p. 271-276.

Metcalf and Eddy Inc., 1971, Storm Water Management Model, Volume I: U.S. Environmental Protection Agency, Washington, D.C., 353 p. 
Mohrlok, U., 1996, Parameter-identifikation in doppel-kontinuum-modellen am beispiel von karst-aquiferen: Tübingen, Germany, Reihe C. Institut und Museum für Geologie und Paläontologie der Universität Tübingen, Tübinger Geowissenschaftliche Arbeiten, v. 31.

Neuman, S.P., and de Marsily, G., 1976, Identification of linear systems response by parametric programming: Water Resources Research, v. 12, no. 2, p. 253-262.

Painter, S.L., Sun, A., and Green, R.T., 2007, Enhanced characterization and representation of flow through karst aquifers — Phase II: Final project report to the Edwards Aquifer Authority and the Southwest Florida Water Management District, $101 \mathrm{p}$.

Panday, Sorab, Langevin, C.D., Niswonger, R.G., Ibaraki, Motomu, and Hughes, J.D., 2013, MODFLOW-USG version 1: U.S. Geological Survey Techniques and Methods, book 6, chap. A45, 66 p.

Peterson, E.W., and Wicks, C.M., 2006, Assessing the importance of conduit geometry and physical parameters in karst systems using the Storm Water Management Model (SWMM), Journal of Hydrology, v. 329, issues 1-2, p. 294-305.

Reimann, T., Birk, S., Rehrl, C., and Shoemaker, W.B., 2011a, Modifications to the Conduit Flow Process Mode 2 for MODFLOW-2005:

Groundwater., doi: 10.1111/j.17456584.2011.00805.x

Reimann, T., Geyer, T., Shoemaker, W.B., Liedl, R., and Sauter, M., 2011b, Effects of dynamically variable saturation and matrix-conduit coupling of flow in karst aquifers: Water Resources Research 47, W11503, doi:10.1029/ 2011WR010446.

Renken, R.A., Cunningham, K.J., Zygnerski, M.R., Wacker, M.A., Shapiro, A.M., Harvey, R.W., Metge, D.W., Osborn, C.L., and Ryan, J.N., 2005, Assessing the vulnerability of a municipal wellfield to contamination in a karst aquifer: Environmental and Engineering Geoscience, v. XI, no. 4, p. 319-331.

Saller, S.P., Ronayne, M.J., and Long, A.J., 2013, Comparison of a karst groundwater model with and without discrete conduit flow: Hydrogeology Journal v. 21, no. 7, p. 1555-1566.
Sauter, Martin, 1993, Double porosity models in karstified limestone aquifers: Field validation and data provision, in Hydrogeological Process in Karst Terranes: International Association of Hydrological Sciences, v. 207, p. 261-279.

Scanlon, B.R., Mace, R.E., Barrett, M.E., and Smith, Brian, 2003, Can we simulate regional groundwater flow in a karst system using equivalent porous media models? Case study, Barton Springs, Edwards aquifer, United States of America: Journal of Hydrology, v. 276, p. 137158.

Schulman, A.E., McKinney, D.C., and John, P.W.M., 1995, Stochastic recharge model for the Edwards aquifer in central Texas: Journal of Water Resources Planning and Management, v. 121, no. 6, p. 479-489.

Sherman, L.K., 1932, Streamflow from rainfall by the unit-graph method: Engineering News Record, v. 108, p. 501-505.

Shoemaker, W.B., Kuniansky, E.L., Birk, S., Bauer, S., and Swain, E.D., 2008, Documentation of a Conduit Flow Process (CFP) for MODFLOW2005: U.S. Geological Survey Techniques and Methods book 6, chap. A24, 50p.

Svensson, U., 2001, A continuum representation of fracture networks, Part I: Method and basic test cases: Journal of Hydrology, v. 250, p. 170-186.

Swain, E.D., and E.J. Wexler, 1996, A coupled surface-water and groundwater flow model (Modbranch) for simulation of stream-aquifer interaction: Techniques of Water Resources Investigations of the U.S. Geological Survey, book 6, chap. A6, 125p.

Takahashi, Y., Rabins, M.J., and Auslander, D.M., 1972, Control and dynamic systems: Reading, Massachusetts, Addison-Wesley Publishing Co., 800 p.

Teutsch, Georg, 1993, An extended double-porosity concept as a practical modeling approach for a karstified terraine, in Gultekin, Johnson, and Back, eds., Hydrogeological processes in karst terraines: Proceedings of the Antalya Symposium and Field Seminar, October 1990: International Association of Hydrological Sciences, v. 207, p. 281-292. 
Teutsch, Georg, and Sauter, Martin, 1991, Groundwater modeling in karst terranes-Scale effects, data acquisition, and field validation: Third Conference on Hydrogeology, Monitoring, and Management of Groundwater in Karst

Terranes, Nashville, Tennessee, December 4-6, 1991, p. 17-35.

Teutsch, Georg, and Sauter, Martin, 1998, Distributed parameter modelling approaches in karst hydrological investigations: Bulletin d'Hydrogeologie, v. 16, p. 99-110.

Trichakis, I.C., Nikolos, I.K., and Karatzas, G.P., 2009, Artificial neural network (ANN) based modeling for karstic groundwater level simulation: Water Resources Management, v. 25, issue 4, p. 1143-1152.

U.S. Department of Agriculture, 1973, Linear theory of hydrologic systems: Agricultural Research Service Technical Bulletin No. 1468, 327 p.

Wanakule, Nisai, 1988, Regression analysis of the San Marcos spring flows and water levels of the index well in San Antonio: Southwest Texas University, Edwards Aquifer Research and Data Center, $34 \mathrm{p}$.

Wanakule, Nisai, and Anaya, Roberto, 1993, A lumped parameter model for the Edwards aquifer: Texas A\&M University, Texas Water Resources Institute, Technical Report No. 163, 84 p.

Watkins, D.W., Jr., and McKinney, D.C., 1999, Screening water supply options for the Edwards aquifer region in central Texas: Journal of Water Resources Planning and Management, v. 125, no. 1, p. 14-24.

Wicks, C.M., and Hoke, J.A., 2000, Prediction of the quality and quantity of Maramec spring water: Groundwater, v. 38, no. 2, p. 218-225.

Zhang, B., and Lerner, D.N., 2000, Modeling of ground water flow to adits: Groundwater, v. 38, no. 1, p. 99-105. 


\title{
Refined Hydrostratigraphic Framework and Model of the Edwards Aquifer, Texas
}

\author{
By S. Beth Fratesi ${ }^{1}$, Ronald T. Green ${ }^{1}$, Ronald M. McGinnis ${ }^{1}$, Hakan Basagaoglu ${ }^{1}$, \\ Leslie Gergen ${ }^{1}$, Jim Winterle ${ }^{2}$, Marques Miller ${ }^{1}$, and F. Paul Bertetti ${ }^{1}$ \\ ${ }^{1}$ Southwest Research Institute ${ }^{\circledR}, 6220$ Culebra, San Antonio, Texas 78238 (www.swri.edu) \\ ${ }^{2}$ Edwards Aquifer Authority, 900 E. Quincy, San Antonio, Texas 78215 (www.edwardsaquifer.org)
}

\begin{abstract}
A refined conceptual and numerical groundwater flow model is being developed for the karstic Edwards aquifer in central Texas. Improved understanding of the Edwards aquifer, its extent, boundary conditions, recharge, and internal hydraulics warrants development of this new conceptualization and model. The refined conceptualization is predicated on an enhanced hydrostratigraphic framework model. The framework has as many as nine separate units, although not all units are pervasive across the model domain. Over 100 faults are explicitly incorporated into the model. The framework was developed to be consistent with hydraulic characteristics of the Edwards aquifer to facilitate calibration of a new numerical model. The ensuing hydrostratigraphic framework and numerical model have resulted in significant refinements to the existing Edwards aquifer geologic framework and groundwater flow model. These refinements provide enhanced opportunity to replicate and predict the hydraulic response of the aquifer.
\end{abstract}




\title{
Simulation of Groundwater Flow in the Edwards-Trinity and Related Aquifers in the Pecos County Region, Texas
}

\author{
By Brian R. Clark ${ }^{1}$, Johnathan R. Bumgarner ${ }^{2}$, Natalie R. Houston ${ }^{3}$, and Adam L.Foster ${ }^{3}$ \\ ${ }^{1}$ U.S. Geological Survey, 700 W. Research Blvd., Fayetteville, AR, 72701 \\ ${ }^{2}$ U.S. Geological Survey, 5563 De Zavala Rd., San Antonio, TX, 78249 \\ ${ }^{3}$ U.S. Geological Survey, 1505 Ferguson Ln., Austin, TX, 78754
}

\begin{abstract}
The Edwards-Trinity aquifer is a vital groundwater resource for agricultural, industrial, and public supply uses in the Pecos County region of western Texas. The U.S. Geological Survey completed a comprehensive, integrated analysis of available hydrogeologic data to develop a numerical groundwaterflow model of the Edwards-Trinity and related aquifers in the study area in parts of Brewster, Jeff Davis, Pecos, and Reeves Counties. The active model area covers about 3,400 square miles of the Pecos County region of Texas west of the Pecos River, and its boundaries were defined to include the saturated areas of the Edwards-Trinity aquifer. The model is a five-layer representation of the Pecos Valley, EdwardsTrinity, Dockum, and Rustler aquifers. The Pecos Valley aquifer is referred to as the alluvial layer, and the Edwards-Trinity aquifer is divided into layers representing the Edwards part of the Edwards-Trinity aquifer and the Trinity part of the Edwards-Trinity aquifer, respectively. The calibration period of the simulation extends from 1940 to 2010. Simulated hydraulic heads generally were in good agreement with observed values; 1,833 out of 2,929 (63 percent) of the simulated values were within 25 feet of the observed value. The average root mean square error value of hydraulic head for the Edwards-Trinity aquifer was 33.61 feet, which was approximately 4 percent of the average total observed change in groundwater-level altitude (groundwater level). Simulated springflow representing Comanche Springs indicates a similar pattern as compared to the observed springflow. Independent geochemical modeling corroborates results of simulated groundwater flow that indicates groundwater in the Edwards-Trinity aquifer in the Leon-Belding and Fort Stockton areas is a mixture of recharge from the Barilla and Davis Mountains and groundwater that has upwelled from the Rustler aquifer.
\end{abstract}

The model was used to simulate groundwater-level altitudes resulting from prolonged pumping to evaluate sustainability of current and projected water-use demands. Each of three scenarios utilized a continuation of the calibrated model. Scenario 1 extended recent (2008) irrigation and nonirrigation pumping values for a 30-year period from 2010 to 2040. The results of scenario 1 indicate widespread declines in groundwater levels ranging from 5.0 to 15.0 feet. Projected groundwater-level declines in and around the Leon-Belding area and the Fort Stockton area are almost nonexistent apart from a small area of decline in the southwestern part of the Leon-Belding area. Scenario 2 evaluated the effects of extended recent (2008) pumping rates as assigned in scenario 1, with year-round permitted values in the Belding area. Results of scenario 2 reflect the modification of year-round pumping in the Belding area through increased declines in groundwater levels (maximum decline of approximately 27.3 feet). The extent of the projected groundwater-level decline in the Leon-Belding area expanded from that of scenario 1 to include much of the central and southern part of the irrigation area. Scenario 3 evaluated the effects of periodic increases in pumping rates over the 30-year extended period. Results of scenario 3 are similar to the results of scenario 2 in terms of the areas of groundwater-level decline. The maximum projected groundwater-level decline increased to approximately 32.7 feet in the Leon-Belding area and the extent of the decline is larger areally than that of scenario 2, joining with an existing area of decline to the north. The localized nature of the projected groundwater-level declines is a reflection of the highly fractured nature of the Edwards-Trinity aquifer. Additionally, the finding that simulated springflow is highly contingent on the transient nature of the underlying hydraulic heads indicates the importance of adequately understanding and characterizing the entire groundwater system. 


\section{REFERENCES}

Bumgarner, J.R., Stanton, G.P., Teeple, A.P., Thomas, J.V., Houston, N.A., Payne, J.D., and Musgrove, Marylynn, 2012, A conceptual model of the hydrogeologic framework, geochemistry, and groundwater-flow system of the Edwards-Trinity and related aquifers in the Pecos County region, Texas: U.S. Geological Survey Scientific Investigations Report 2012-5124 (revised July 10, 2012), 74 p., available at http://pubs.usgs.gov/ds/678/.

Clark, B.R., Bumgarner, J.R., Houston, N.A., and Foster, A.L., 2014, Simulation of groundwater flow in the Edwards-Trinity and related aquifers in the Pecos County region, Texas: U.S. Geological Survey Scientific Investigations Report 2013-5228, 56 p., available at http://pubs.usgs.gov/sir/2013/5228/.

Pearson, D.K., Bumgarner, J.R., Houston, N.A., Stanton, G.P., Teeple, A.P. and Thomas, J.V., 2012, Data collection and compilation for a geodatabase of groundwater, surface-water, water-quality, geophysical, and geologic data, Pecos County region, Texas, 1930-2011: U.S. Geological Survey Data Series 678, 67 p., available at http://pubs.usgs.gov/ds/678/.

Thomas, J.V., Stanton, G.P., Bumgarner, J.B., Pearson, D.K., Teeple, A.P., Houston, N.A., Payne, J.P., and Musgrove, MaryLynn, 2012, A conceptual model of the hydrogeologic framework, geochemistry, and groundwater-flow system of the Edwards-Trinity and related aquifers in the Pecos County region, Texas: U.S. Geological Survey Fact Sheet 2013-3024, 6 p., available at http://pubs.usgs.gov/fs/2013/3024/. 


\title{
Automatic Methods of Groundwater Flow Model Construction of the Ozark Plateaus Aquifer System
}

\author{
By Brian R. Clark ${ }^{1}$ and Joseph M. Richards ${ }^{2}$ \\ ${ }^{1}$ U.S. Geological Survey, 700 West Research Blvd., Fayetteville, AR 72701 \\ ${ }^{2}$ U.S. Geological Survey, 1400 Independence, Rolla, MO 65401
}

\begin{abstract}
As computational speeds increase, highly parameterized groundwater flow models are becoming more common. A typical model may include thousands or tens of thousands of parameters representing components of hydraulic properties, recharge, boundary conditions, and stresses. Often these parameters are estimated or include measured values that include a certain degree of error. The sensitivity of simulation results to the accuracy of these parameters or to variability in these parameters is evaluated by comparing changes in parameter values to the resultant effect on simulated water levels and flows. The scale of horizontal and vertical discretization used to develop the model grid may introduce structural noise into the simulation, however, and changes in grid dimensions can directly affect calibrated parameters. Despite this recognized dependence of model parameters on the underlying grid, grid dimensions typically are developed early in the model construction process and are based on a quick computation of potentially active cells with some regard to the resolution of existing data and the purpose of the simulation. The grid dimensions are then held constant throughout the modeling process. Using automated scripting methods to dynamically rediscretize a model grid allows the grid dimensions to become parameters that also can be evaluated by using sensitivity analysis to optimize the cell sizes and layering, and minimize the structural noise.

The challenge of including grid dimensions as a parameter of the model is that the model grid is the basis of all model inputs (layer, row, and column is the typical method to reference the location of all features in a model), and changes to the dimensions of the grid affect how all simulated features are represented. Therefore, the automated scripting methods must be capable of intersecting each feature within the model grid and creating appropriate model files. The Python ${ }^{\circledR}$ scripting language provides robust methods to interface with database structures, text-based files, and spatial data files. Initial tests of the scripts applied to information about the Ozark Plateaus aquifer system indicate potential in evaluating the sensitivity of grid dimensions to groundwater-level altitude. The scripts are used to create the grid (with associated layer elevations), split layers if desired, assign hydraulic parameter zones, create observation files, and create preliminary river and drain files. Post-processing scripts are included as final steps in the process. These scripts calculate residual statistics and produce plots for comparison to other simulations using various grid dimensions.
\end{abstract}

\section{REFERENCE}

U.S. Geological Survey, 2014, Ozark Plateaus groundwater availability study, accessed February 20, 2014, at http://ar.water.usgs.gov/ozarks/. 


\title{
CHEMICAL FATE AND TRANSPORT
}

\section{Transport of Salt, Trace Metals, and Organic Chemicals from Parking Lot and Road Surfaces into Mammoth Cave}

\author{
By David Solomon ${ }^{1}$, Irucka Embry ${ }^{\star}$, Bobby Carson ${ }^{3}$, Larry Johnson ${ }^{3}$, Roger Painter ${ }^{1}$, \\ Lonnie Sharpe ${ }^{1}$, Rickard Toomey, III $^{3}$, and Thomas D. Byl ${ }^{1,2}$ \\ ${ }^{1}$ Tennessee State University, College of Engineering, 3500 John A Merritt Blvd., Nashville, TN 37209 \\ ${ }^{2}$ U.S. Geological Survey, 640 Grassmere Park, Suite 100, Nashville, TN 37209 ( ${ }^{*}$ contract employee) \\ ${ }^{3}$ Mammoth Cave International Center for Science and Learning, Science \& Resource Management, \\ Mammoth Cave National Park, KY 42259
}

\begin{abstract}
Mammoth Cave National Park in south-central Kentucky is the world's longest known cave system and is host to many unique and threatened species including the Kentucky cave shrimp. The National Park Service operates Mammoth Cave National Park to educate tourists while still protecting the unique and fragile ecosystem in the cave. The Park in partnership with Tennessee State University and the U.S. Geological Survey has established a monitoring system to characterize selected chemicals transported from parking lots and dissolved salt from winter-treated roads. The project was initiated, in part, because of the high volume of traffic into and through the Park, and because the Park has begun phasing in the application of brine and rock salt to melt ice on primary roads through the Park. The scope of this investigation included six surface monitoring stations and two cave streams for the winter road-runoff study, and seven surface drains and six cave sites for the parking lot segment of the project. Chemical analysis of road runoff included grab samples between and during storms, and continuous measurement of specific conductance as a surrogate measure of salt concentration. Chemical analysis of parking lot runoff included quaternary ammonia compounds, anionic surfactants, nitrate, ammonia, zinc, and copper.

The road-runoff monitoring sites were selected based on their location with respect to primary roads targeted for salt treatment, traffic volume, drainage qualities, and drainage to critical cave shrimp habitat. This project began in 2011 prior to any road treatments in the Park, and continued through the winter of 2013. Specific conductance meters and autosamplers were used to monitor the runoff waters. There were three brining events in January 2013. The specific conductance of road runoff during the January 2013 storms ranged from 50 to 400 microSiemens per centimeter $(\mu \mathrm{S} / \mathrm{cm})$ at 25 degrees Celsius. Specific conductance of road storm runoff during winter storms with no brine or salt applications ranged from 50 to $300 \mu \mathrm{S} / \mathrm{cm}$. Analysis of the specific conductance pattern on the surface and in the corresponding cave found that it took from 0.5 to 3 hours for road runoff to reach the mid-level of the cave.

The parking lot sampling sites were associated with storm filters. First-flush storm samplers and random grab samples were collected from 2011-2014. Concentrations of quaternary ammonia compounds ranged from below detection ( $<0.1$ milligrams per liter $(\mathrm{mg} / \mathrm{L})$ ) to a high of $22 \mathrm{mg} / \mathrm{L}$ in storm runoff from an RV waste transfer station. Quaternary ammonia compound concentrations in Annette's Dome (in the cave below the RV waste transfer station) exceeded $0.5 \mathrm{mg} / \mathrm{L}$ two times in the summer of 2012 (5.4 and $2.5 \mathrm{mg} / \mathrm{L}$ ). Copper and zinc concentrations were less than $1 \mathrm{mg} / \mathrm{L}$ in all monitored events. Nitrate (as $\mathrm{N}$ ) and ammonia concentrations spiked as high as 29 and $22 \mathrm{mg} / \mathrm{L}$, respectively, in parking lot runoff from areas frequented by grazing deer. The concentration of ammonia in most surface runoff was less than 1 $\mathrm{mg} / \mathrm{L}$, and nitrate (as $\mathrm{N}$ ) rarely exceeded $5 \mathrm{mg} / \mathrm{L}$. Concentrations of ammonia and nitrate in the cave were generally less than half the surface concentrations. The anionic surfactant concentrations in the surface runoff samples were generally less than 10 micrograms per liter $(\mu \mathrm{g} / \mathrm{L})$ with an occasional spike as high as $100 \mu \mathrm{g} / \mathrm{L}$ in runoff draining the biosecurity mats. Trace concentrations $(<5 \mu \mathrm{g} / \mathrm{L})$ of anionic surfactants were detected at all the cave sampling sites and probably represent natural surfactants. The results of the investigation indicate that concentrations are diluted as water moves from the land surface into the cave.
\end{abstract}




\title{
CAFOs on Karst-Meaningful Data Collection to Adequately Define Environmental Risk, with a Specific Application from the Southern Ozarks of Northern Arkansas
}

\author{
By Van Brahana ${ }^{1}$, Joe Nix ${ }^{2}$, Carol Bitting ${ }^{3}$, Chuck Bitting ${ }^{4}$, Ray Quick ${ }^{5}$, John Murdoch ${ }^{6}$, \\ Victor Roland ${ }^{7}$, Amie West ${ }^{7}$, Sarah Robertson ${ }^{8}$, Grant Scarsdale ${ }^{9}$, and Vanya North ${ }^{5}$ \\ ${ }^{1}$ Department of Geosciences, 20 Ozark Hall, University of Arkansas, Fayetteville, AR 72701 \\ ${ }^{2}$ Ouachita Baptist University Water Lab, Arkadelphia, AR 71988 \\ ${ }^{3} \mathrm{HC} 73$, Box 182 A, Marble Falls, AR 72648 \\ ${ }^{4}$ National Park Service, Harrison, AR, 72601 \\ ${ }^{5}$ Department of Geosciences, 216 Ozark Hall, University of Arkansas, Fayetteville, AR 72701 \\ ${ }^{6} 11908$ Elk Ridge Rd., Wesley, AR 72773 \\ ${ }^{7}$ Program of Environmental Dynamics, 216 Ozark Hall, University of Arkansas, Fayetteville, AR 72701 \\ ${ }^{8} 243$ South Gregg Ave., Fayetteville, AR 72701 \\ ${ }^{9} 303$ Oxford, Harrison, AR 72601
}

\begin{abstract}
Karst typically contains a noticeably larger percentage of groundwater in its hydrologic budget than insoluble lithologies. Because subsurface flow is not directly observable, flow quantity, flow direction, flow velocity, water quality, groundwater basin delineation, and hydrologic variation with changing water levels are key components essential to characterizing the hydrogeology and assessing contaminant risk in karst aquifers. Concentrated animal feeding operations (CAFOs) are but one of the many sources of contamination that have been documented in karst, and owing to the large concentration of animal wastes generated by these factory farms and their potential for allowing pollution to enter nearby waters, these nonpoint sources require thorough and careful study prior to permitting by state and federal environmental agencies. Environmental impact statements and preconstruction studies are essential to preserve the environmental and ecological integrity of karst basins. Remediation is typically much more expensive and commonly requires more time to mitigate the damage.

The state environmental protection agency (Arkansas Department of Environmental Quality [ADEQ]) approved the construction of a 6,500-head swine CAFO in accordance with existing regulations on karst terrain in the area of Big Creek basin in Newton County, Arkansas. The CAFO lies less than 10 kilometers from the confluence of Big Creek with the Buffalo National River, a National Park Service facility that is the main drain from this karst drainage basin. The Buffalo National River is one of the few free-flowing rivers remaining in the contiguous 48 states, hosting various recreational activities, including canoeing, fishing, and swimming, in addition to ecosystems for a large number of unique aquatic and endangered bat species. This CAFO was permitted under a General Permit which did not require appropriate investigations, including a hydrogeologic study, a karst study, and an evaluation of groundwater/surface water interaction. Newton County is characterized by karst hydrogeology, containing more known caves than any other county in Arkansas. Operation of the CAFO has been the subject of much debate and has pitted the landowners and small family farms against big-agriculture factory farming. This paper describes the resulting pro bono research that was undertaken to fill in essential data originally missing (hydrogeology, karst inventory, dye tracing, water quality), and the continuing effort to educate the local landowners about a resource that moves unseen beneath the ground. It has strong technical components, but more importantly, has a direct relevance to the human impacts of our science on environmental justice and policy.
\end{abstract}




\section{INTRODUCTION}

Karst regions typically are considered to be vulnerable with respect to various anthropogenic land-use activities, owing to the intimate association of surface and groundwater. Inasmuch as the soluble rocks of the karst landscape can be dissolved to create large, rapidflow zones that compete successfully with surface streams, groundwater and subsurface flow represent a much larger component of the hydrologic budget in karst regions than in areas where non-soluble rocks predominate. Karst areas typically are distinguished by being unique, but some general approaches can be applied to characterize the hydrology of the area. These approaches include an evaluation of the degree of karstification, the hydrologic attributes of the groundwater flow system, the baseline water quality, the time-of-travel through the karst flow system, and the general flux moving through the system. The nature of potential contaminants and their total mass and range of concentrations are critical to understanding the potential environmental risk. Using these approaches, it is possible to represent a minimum level of hydrogeologic characterization to assess environmental risk in a karst area. Wellestablished, fast-flow systems with structural deformation likely will demand more complete study, but lacking the aforementioned minima, the cost of remediating contamination is typically increased many fold.

CAFOs are but one of many industrial activities that pose a threat to the environmental integrity of a karst basin. The typically large number of animals (from hundreds to more than a hundred thousand animals-most commonly cattle, pigs, chickens and turkeys) generate wastes in solid, liquid, and gaseous phases. Our focus in this paper is limited to nitrate and total phosphorus, major dissolved constituents, organics, sediment, and pathogens.

The objectives of this paper are threefold. The first is to describe minimal requirements for siting any facility on karst.

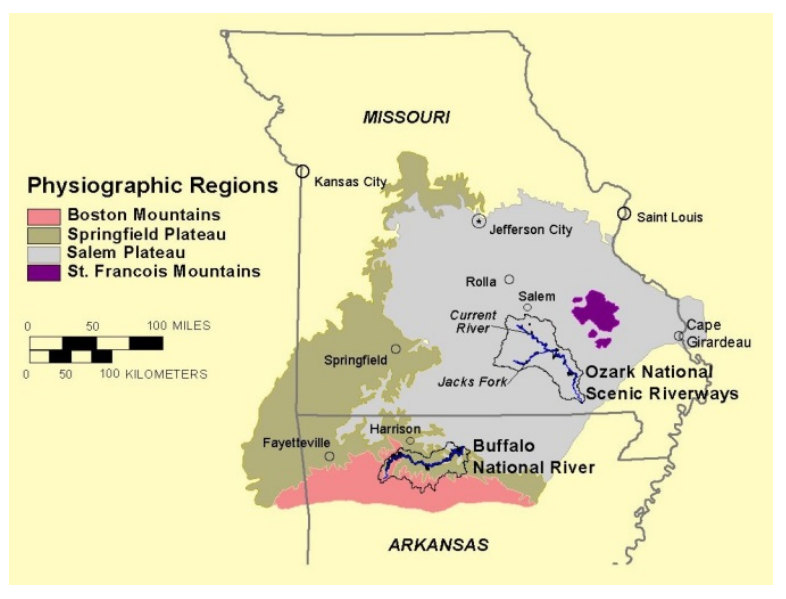

Figure 1. General area of major physiographic regions of the Ozark Plateaus, including the Buffalo National River and the Ozark National Scenic Riverways, two unique and Extraordinary Resource Waters that are part of the National Park Service. The karst area discussed in this study is restricted to the Springfield Plateau in the area of the Buffalo National River. Figure from Adamski and others (1995).

From a hydrogeologic standpoint, much of this objective is a reiteration of commonly wellknown sampling requirements in karst (Quinlan, 1989; Alexander, 1989). The second objective is to provide an abbreviated case study from the southern Ozarks in northern Arkansas, in the drainage basin of the Buffalo National River (fig. 1 ), which shows that implementation of meaningful environmental impact studies for potentially risky industrial activities on karstlands is fraught with politics and emotion. The third objective is to propose a scientifically-sound, thorough, fair approach for the ultimate achievement of environmental justice for the greatest number of stakeholders.

\section{MINIMAL STUDY REQUIREMENTS FOR INDUSTRIAL ACTIVITIES PROPOSED ON KARSTLANDS}

Based on the seminal work of Quinlan (1989), we have modified his original assessment of required study components to include what we believe are minimum questions that should be answered prior to siting CAFOs on karst.

1. Compile, study and interpret topographic, soils, and geologic maps, and all related previous hydrogeologic studies of the area. Fully document this in a list of selected references. 
2. Conduct a complete karst inventory, including input, flow through, and discharge features accurately plotted on topographic and geologic maps of appropriate scale.

3. Determine groundwater-flow directions, flow type, velocities, and water budgets, and estimate groundwater basin boundaries using the principle of normalized base flow (Brahana, 1997).

4. Characterize the baseline water quality of the shallow karst aquifer and overlying and underlying aquifers to assess interaquifer transfer of flow and contaminants, including dissolved major constituents, original contaminants and their breakdown products from the industrial operation, and in the case of CAFOs, key nutrients, pathogens, sediments, and other unique waterquality indicator parameters.

5. Conduct dye-tracing studies concurrently with items 3 and 4, using study results to answer questions raised in item 2 .

6. Integrate items 1 through 5 into a report that synthesizes groundwater hydrologic characteristics in the karst aquifer, proposes a defensible conceptual model, and accurately assesses the background water quality prior to the permitting of the industrial operation. Insofar as the complexity of the karst is not well understood by disciplines outside geology, this study should be conducted only by a registered professional geologist.

\section{CASE STUDY OF THE INDUSTRIAL HOG CAFO ON THE KARST OF BIG CREEK BASIN, NEWTON COUNTY, ARKANSAS}

The approval by the Arkansas Department of Environmental Quality (ADEQ) of a 6,500-head swine facility on Big Creek less than 10 kilometers upstream from the Buffalo National River (fig. 2) was approved on August 3, 2012. This approval came as a surprise to almost all stakeholders in the region, not the least of whom was the National Park Service (NPS), the agency responsible for maintaining the environmental quality of the Buffalo River, which is classified as an Extraordinary Resource Water. The resulting furor brought deeply held emotions to the surface. Unfortunately, space constraints for this paper limit discussion to only key elements of the controversy, but the interested reader is directed to the following websites, each of which offers disparate views of the facts. These sources represent web pages of some of the major participants, and additional information can be acquired from pointers on each webpage, or web searches using examples such as the Buffalo National River, Big Creek Hog Farm, or Newton County, Arkansas Hog Farm, to name a few. Some specific connections with those involved and shown in parentheses are:

http://www.arfb.com/ (Arkansas Farm Bureau);

http://www.adeq.state.ar.us/ (ADEQ);

http://www.cfra.org/news/140127/corporatefarming-notes-industrial-hog-operation-dividescommunity (Center for Rural Affairs);

http://www.npca.org/news/mediacenter/press-releases/2013/groups-go-to-court-toprotect (National Parks Conservation Association);

http://www.ozarksociety.net/2013/03/conserv ation-issue-hog-farm-near-big-creek/ (Ozark Society);

http://buffaloriveralliance.org/Default.aspx?p ageId=1547312 (Buffalo River Alliance);

http://www.npca.org/news/mediacenter/press-releases/2013/groups-go-to-court-toprotect.html.

It should be noted that these sources reflect the bias of each support group, and that misrepresentations or inaccuracies may be present on non-peer-reviewed web pages. These are provided to assist the reader and to show how distinctly different interpretations are possible from the same data set. The difference lies in the filters, the fears, the politics, and the emotional reactions of each stakeholder. 


\section{Selected Components of the Permitting Process}

As previously mentioned, the permit for the CAFO was granted by ADEQ according to existing regulations, which did not include a through characterization of the site. The geology, hydrology, and unique karst terrain were not adequately considered. Additionally, no predevelopment characterization was made to evaluate the true effects of the CAFO on the watershed.

\section{Site Geology, Hydrogeology, Karst, and Hydrology}

Big Creek is one of the two largest tributaries to the Buffalo National River, encompassing about 8 percent of the total drainage of the entire Buffalo River watershed. Physiographically, tributaries head in uplands of the Boston Mountains Plateau (fig. 1) on terrigenous sediments of Pennsylvanian age and flow generally toward the north with relatively steep gradients. The stratigraphic units of concern are within the Boone Formation (Braden and Ausbrooks, 2003), an impure limestone that contains as much as 70 percent chert, much of which was thought to have formed through geochemical alteration of volcanic ash from atmospheric deposition from the island arcs south of the Ouachita Orogeny, approximately 150 kilometers south of study area. The upper and lower units of the Boone Formation have much less chert (typically less than 5 percent) than the middle part of the Boone. Structurally, the Boone is near-horizontal; owing to the high concentration of brittle chert, it has been subjected to extensional faulting and jointing. The upper and lower parts of the Boone Formation host significant caves (fig. 4) in the region (Mott and others, 2000). Intervening layers of limestone are karstified by smaller dissolution features (fig. 5), with the chert acting as confining units above and below.

The geologic unit underlying the CAFO is the Boone Formation, and all formations in Big Creek basin are shown in figure 3. Approximately 50 meters of the middle Boone limestone/chert lithology is exposed in a cliff face about 2 kilometers downstream from the CAFO (fig. 6). Big Creek is characterized by both gaining and losing reaches where it crosses the Boone Formation, and during low flow there are entire reaches that are completely dry downstream of flowing reaches.

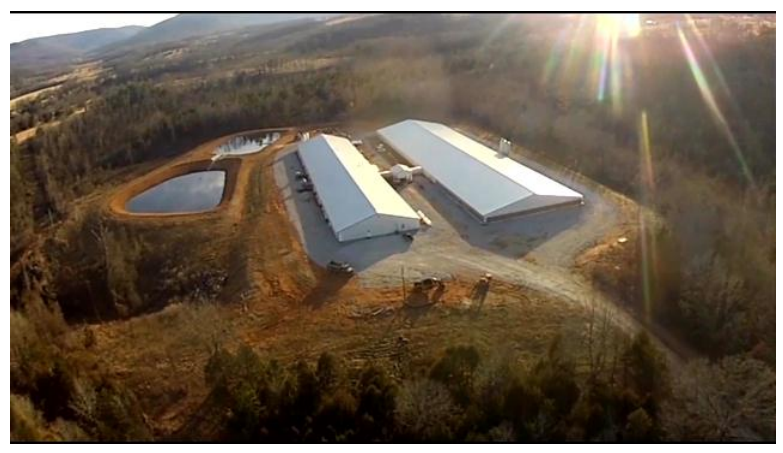

Figure 2. Aerial view of 6,500-head industrial hog CAFO, including waste lagoons. The facility is sited on the Boone Formation, a karst aquifer less than $10 \mathrm{~km}$ upstream from the confluence of Big Creek with the Buffalo National River.

\section{Stratigraphic Column}

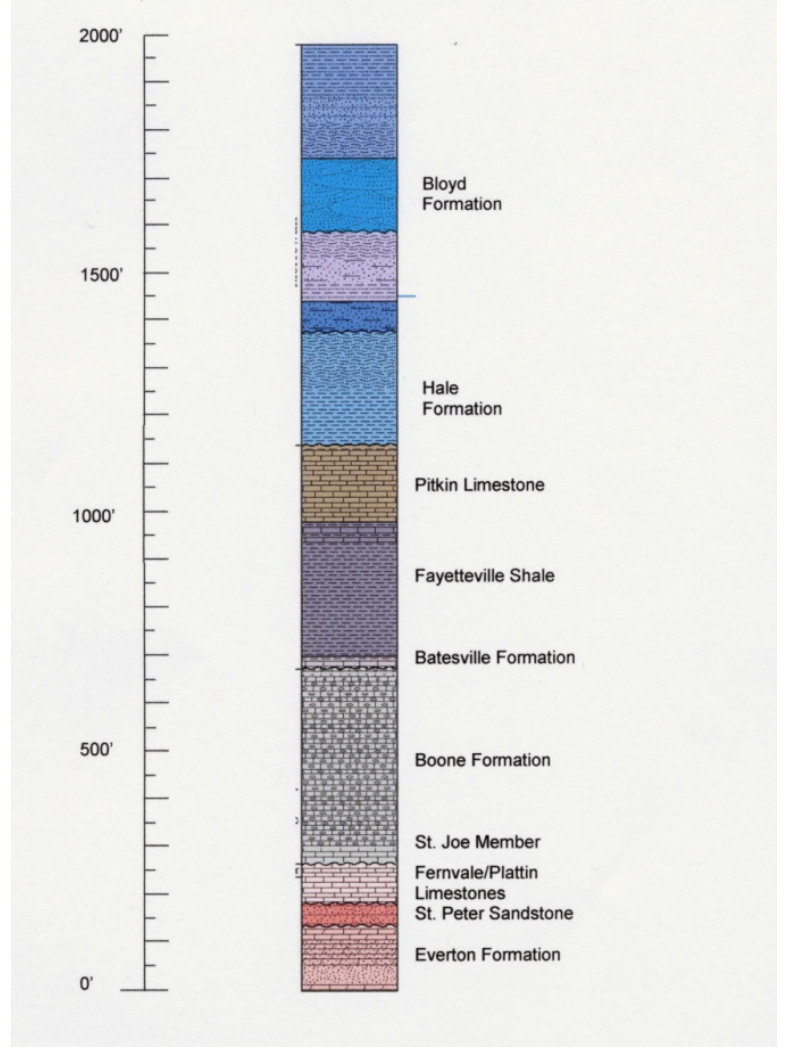

Figure 3. Stratigraphic column of most of Big Creek basin in the vicinity of the CAFO, from the Mt. Judea 7.5-minute quadrangle (Braden and Ausbrooks, 2003). 
Big Creek and its major tributary, Left Fork, flow in alluviated valleys composed of nonindurated sediments, primarily chert and terrigenous rock fragments from younger, topographically higher formations (fig. 3). The alluvium in these valleys varies in thickness from a feather-edge to about 8 meters. Outcrops of the Boone Formation are common in the streambed. Springs are common along the entire reach of Big Creek, ranging from relatively small discharges in the tens of liters per minute range to large discharges of tens of liters per second. These larger discharges resurge from relatively pure limestone lithologies (Mott and others, 2000).

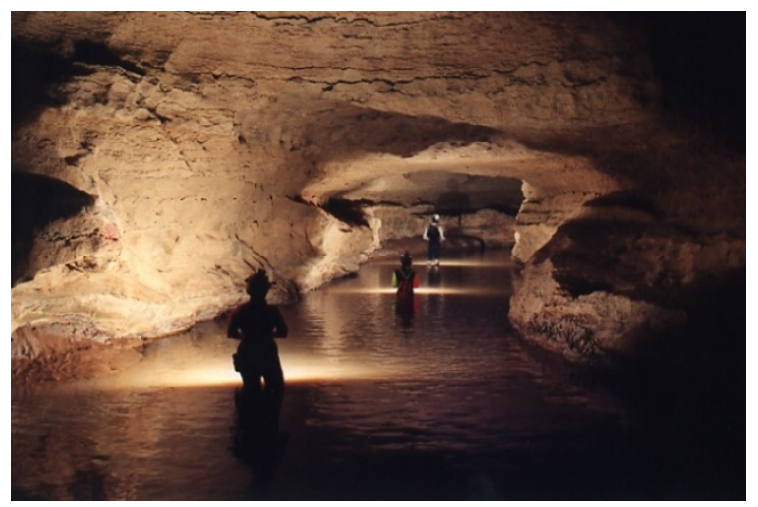

Figure 4. Newton County, where Big Creek occurs, has the largest number of recorded caves of all counties in the state. Most of these, such as this cave just north of Big Creek basin on the Buffalo River, are concentrated in the upper and lower parts of the Boone and St. Joe Formations, which include more pure limestone. Photo by Carol Bitting.

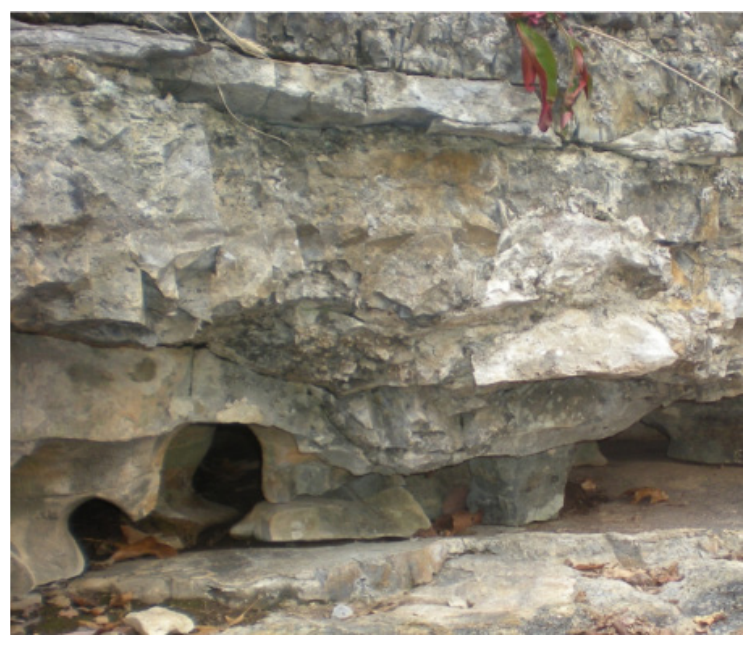

Figure 5. Karst dissolution features in limestone interbedded with chert from the middle Boone Formation. The chert acts as an insoluble confining unit for the karst. The scale of these voids typically ranges from 2 to more than $5 \mathrm{~cm}$.
The existence of well-developed karst near a NPS facility designated as an Extraordinary Resource Water, increases vulnerability to anthropogenic sources of contaminants that can move through the hydrologic cycle with little attenuation of contaminants. The concentrated wastes of the CAFO and the calculated allowable leakage through the clay of the lagoon liner (fig. 7) and the waste-spreading fields (fig. 8) are perceived as being a risk, not only to the ecology and environmental integrity of Big Creek, but to the Buffalo National River, with the extensive direct contact of its waters with the many tourists who canoe and swim there. The lack of any geologic, hydrogeologic, or karst studies do not allay fears related to assessing the overall risk this CAFO poses.

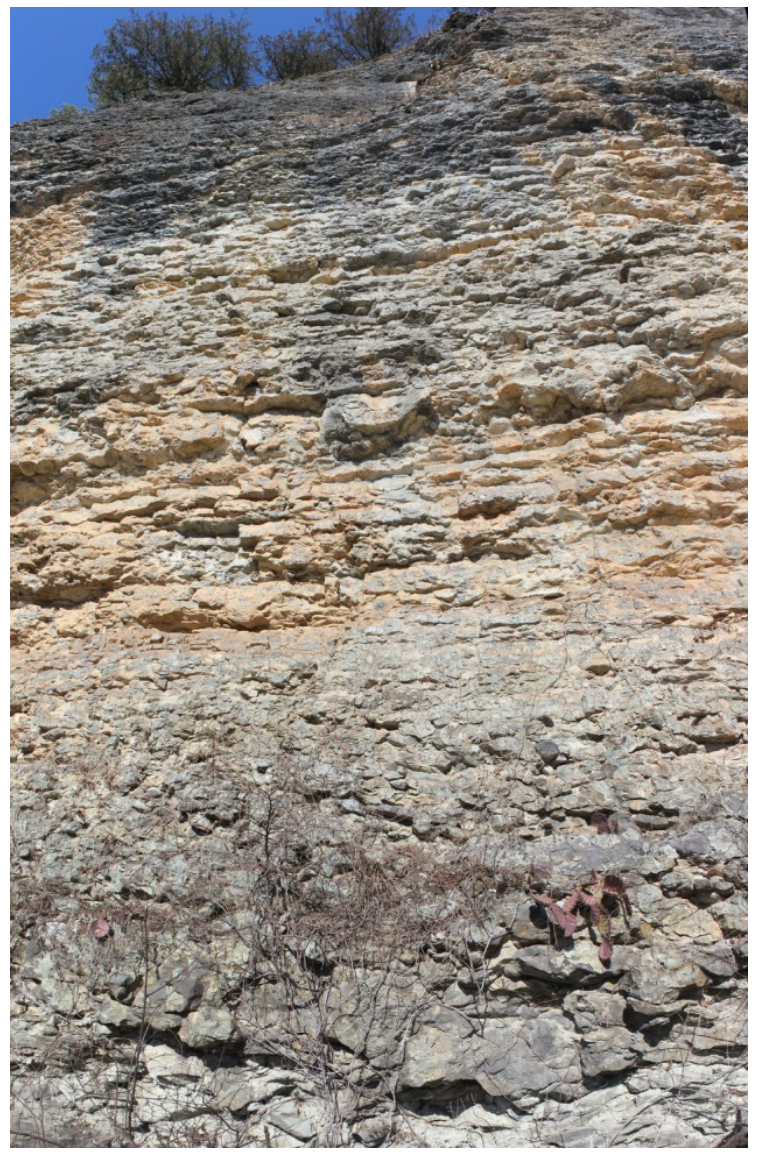

Figure 6. Erosional bluff face showing approximately $50 \mathrm{~m}$ of interbedded limestone and chert in the middle part of the Boone Formation near the confluence of Big Creek with its major tributary, Left Fork. The differential weathering suggests that this landscape reflects the solubility of the limestone facies. Photo courtesy of John Murdoch. 
In response to the lack of appropriate hydrogeologic and karst studies of the basin associated with the CAFO, a diverse group of volunteers (the authors) proposed a pro bono investigation of several unstudied elements that would minimally describe 1) the karst inventory in Big Creek basin, and its relation to the geology; 2) the baseline groundwater quality, including an assessment of expected capability of the soil/regolith/bedrock flow system to accommodate additional wastes; and 3) the general flow directions, rates of flow, quantities of flow, and water budgets based on dye tracing. The interpretation of these field data are expected to be shared with all stakeholders in a report.

Geologic, hydrologic, and karst inventories which were outlined earlier under minimal study requirements were conducted. These were accomplished by an intensive map and previously published reports study, intensive field work to identify gaining and losing reaches, caves, springs, sinkholes and visible karst landforms, low-level aerial surveillance, and canvassing of the local farmers and landowners.

Strict baseline water-quality (pre-CAFO) sampling was not possible, but the slow startup of the CAFO in the summer of 2013 allowed sampling approximately 40 wells, springs, and

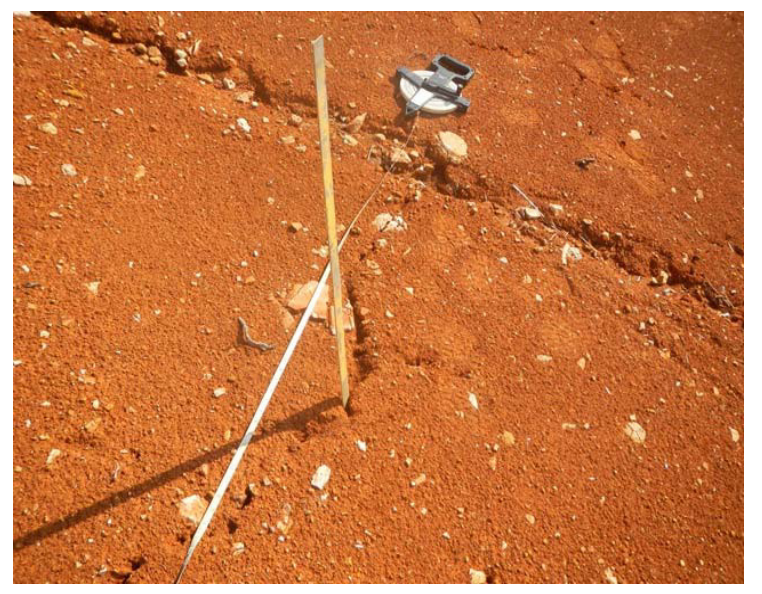

Figure 7. The clay liner shown here is the sole confining entity separating the hog waste in the lagoons from the underlying Boone Formation. This photo, taken after construction of the liner, indicates that it has numerous chert fragments up to fist size within the clay, and dessication cracks, and that erosion rills have eroded some of the thickness. These features reduce its ability to confine. The liner was required to be $30 \mathrm{~cm}$ thick, but the owners of the CAFO increased that to $45 \mathrm{~cm}$. Photo courtesy of Tony Morris (ADEQ).

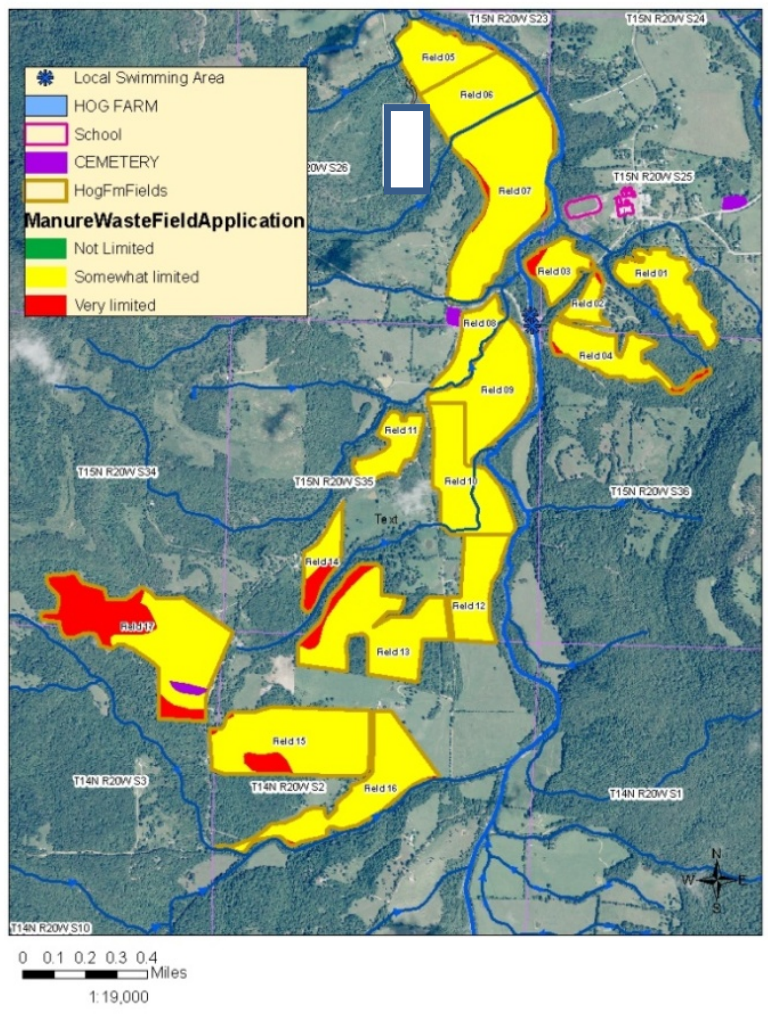

Figure 8. Fields permitted for spreading hog waste along Big Creek by the CAFO (white color) granted by ADEQ. Most of the permitted fields are on alluvium and regolith that directly overlie the Boone Formation at thicknesses ranging from a feather edge to about $8 \mathrm{~m}$. The proximity to Mt. Judea school (magenta color) to the spreading fields is shown in the upper right-hand corner of the figure.

streams for field parameters, major dissolved constituents, nutrients, and pathogens prior to the major CAFO activity. Nutrients and pathogens were analyzed by the Arkansas Water Quality Lab on the campus of the University of Arkansas owing to the short holding-time requirements, and dissolved major and selected trace constituents were analyzed by the Water Quality Lab of Ouachita Baptist University in Arkadelphia.

The dye-tracing study has yet to be undertaken, because permission to inject nontoxic fluorescent dyes was just granted in midMarch 2014. 
lagoon with 45-cm "liner"

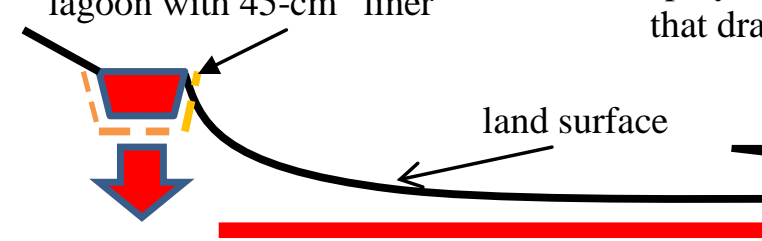

West spraying waste on fields adds additional contaminants that drain downward into the underlying karst

permeable voids created by secondary dissolution in karstified limestone of the

Boone Formation transmit hog waste and related contaminants to Big Creek

Big Creek

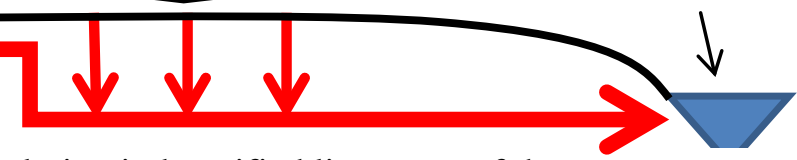

East

Figure 9. Conceptual model showing surface and groundwater interaction in a cross-sectional view in the area of Big Creek near the hog CAFO. Red arrows identify potential karst flow pathways that were not characterized or previously studied.

\section{Preliminary Results}

Description of the geology and karst of Big Creek basin in the area of the CAFO support the observation that the Boone Formation is a mantled karst with numerous springs and a high degree of surface and groundwater interaction. Sinkholes are typically not common in the middle part of the Boone, but springs and secondary zones of limestone dissolution between chert layers are. The large number of caves in the basin (fig. 10) provides additional support for large discharge, rapid-flow systems with turbulent flow that have the ability to transport not only conservative solutes, but nutrients, sediment, and pathogens. At this time, the shallow karst aquifer is dominated by bicarbonate water type,

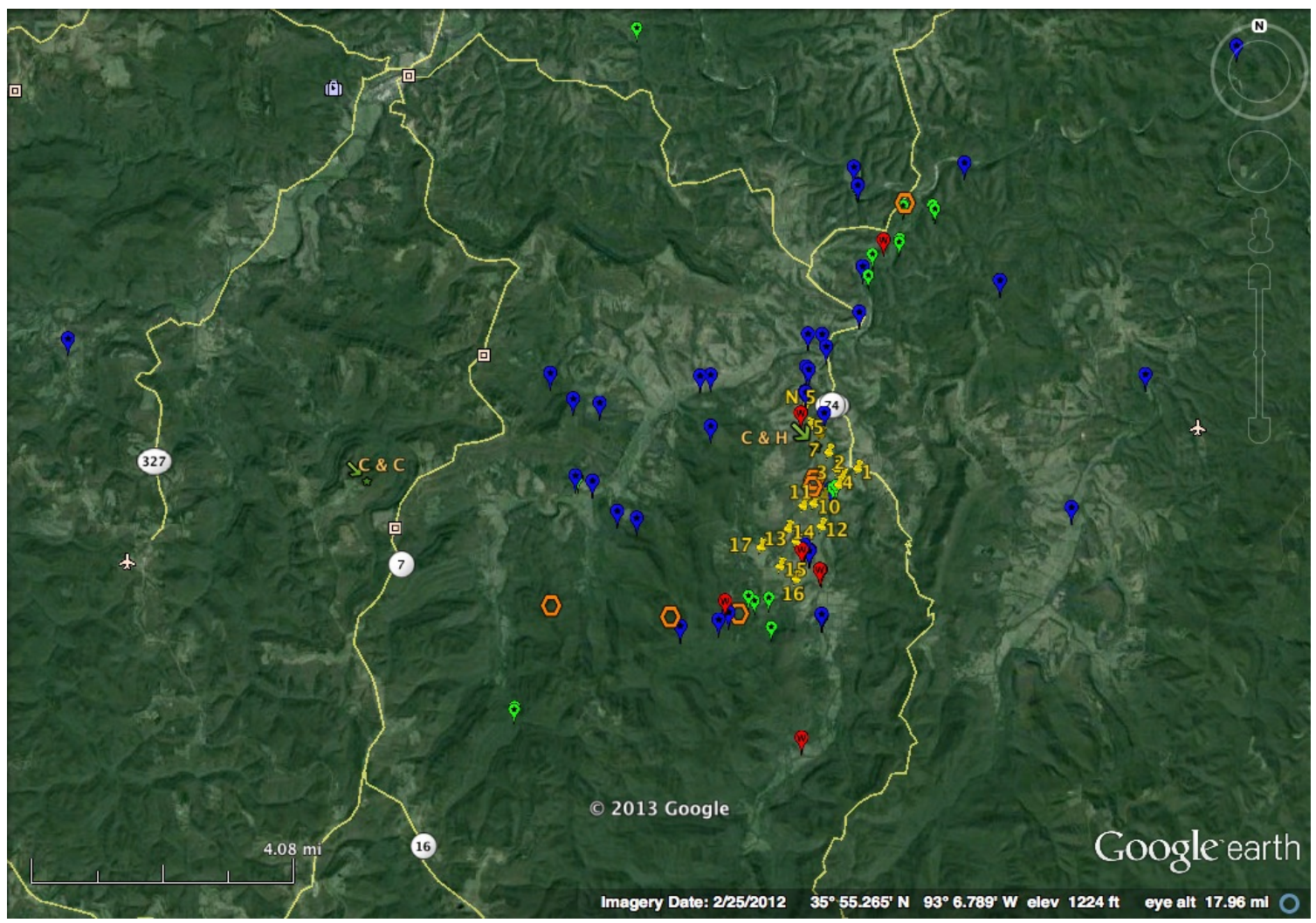

Figure 10. Locations of selected reference points, sampling sites, spreading fields permitted for the CAFO, caves, and springs in Big Creek and contiguous basins. Spreading fields are yellow, springs are blue, caves are green, surface-water sampling sites are red, major roads are in white, forested regions are dark green, and cemeteries are brown. Locations are from GPS measurements plotted on Google Earth. 
dissolved solids generally less than 400 milligrams per liter $(\mathrm{mg} / \mathrm{L})$, groundwater temperatures consistent with shallow karst flow (summer temperatures in the $16-19^{\circ} \mathrm{C}$ range, winter temperatures in the 12 to $14{ }^{\circ} \mathrm{C}$ range), nutrients elevated above background levels (e.g. nitrates in the range of 2 to $>10 \mathrm{mg} / \mathrm{L}$ ), reflecting effects of anthropogenic land uses, and pathogens, some as high as tens to hundreds of thousands of colony forming units (cfu) per $100 \mathrm{~mL}$, indicating little or no attenuation.

Recent groundwater analyses show no contamination from the CAFO; however, these data are from select locations. Therefore, some monitoring points may not be included due to the diverse nature of the karst system and the inability to get permission to sample locations on private property.

\section{PROPOSAL FOR OPTIMIZING THE INCORPORATION OF SCIENCE, POLICY, AND TRANSPARENCY INTO FUTURE STUDIES OF PERMITTING INDUSTRIAL ACTIVITIES ON KARST}

1. Include all stakeholders at the table, exclude no one.

2. Promote an environment of openness, wherein no favored or powerful group dominates other stakeholders.

3. Verify and document all facts and aspects of potential problems, especially if it appears that this is a karst system.

4. If disinformation or deceit are evident, confront these.

5. Be respectful.

6. Use a holistic approach to the proposed activity, including scientific and human considerations that are relevant.

7. Reframe the discussion to avoid words or terms that are incendiary, and allow reasonable options.

8. Above all else, base decisions and regulations on science and on treating others the way you would like to be treated.

\section{SELECTED REFERENCES}

Adamski, J.C., Petersen, J.C., Freiwald, D.A., and Davis, J.V., 1995, Environmental and hydrologic setting of the Ozark Plateaus study unit, Arkansas, Kansas, Missouri, and Oklahoma: U.S. Geological Survey Water-Resources Investigations Report 94-4022, 69 p.

Alexander, E.C., Jr., 1989, Karst hydrogeology and the nature of reality: Philosophical musings of a frustrated curmudgeon: Keynote address given at Second Environmental Problems in Karst Terranes and Their Solutions Conference, Nashville, Tennessee, November 16-18, 1988, National Water Well Association, Dublin, Ohio.

Aley, T., 1988, Complex radial flow of ground water in flat-lying residuum-mantled limestone in the Arkansas Ozarks, in Second Environmental Problems in Karst Terranes and Their Solutions Conference, Nashville, Tennessee, November 16-18, 1988, Proceedings, v. 2, p. 159-170.

Al-Qinna, Mohammed, Scott, H.D., Brye, K.R., Brahana, J.V., Sauer, T.J., and Sharpley, A.N., Coarse fragment effects on soil physical and hydraulic properties in a mantled-karst landscape in the Ozark Highlands: Soil Science, 20 p., [in review with journal].

Braden, A.K., and Ausbrooks, S.M., 2003, Geologic map of the Mt. Judea quadrangle, Newton County, Arkansas: Arkansas Geological Commission, scale 1:24,000.

Brahana, J.V., 1997, Rationale and methodology for approximating spring-basin boundaries in the mantled karst terrane of the Springfield Plateau, northwestern Arkansas, in Beck, B.F., and Stephenson, J. Brad, eds., Sixth Multidisciplinary Conference on Engineering Geology and Hydrogeology of Karst Terranes, A.A. Balkema, Rotterdam, p. 77-82.

Brahana, Van, 2009, The Savoy Experimental Watershed-A long-term research site for karst hydrogeology, in Palmer, A.N., and Palmer, M.V., Caves and karst of the USA: National Speleological Society Guidebook for the International Congress of Speleology, section 5Ozark Plateaus, p. 179.

Brahana, V., 2011, Ten relevant karst hydrogeologic insights gained from 15 years of in situ field studies at the Savoy Experimental Watershed, in Kuniansky, E., ed., U.S. Geological Survey Karst Interest Group Proceedings, Fayetteville, AR, April 26-29, 2011: U.S. Geological Survey 
Scientific Investigations Report 2011-5031, p. 132-141.

Brahana, J.V., Hays, P.D., Kresse, T.M., Sauer, T.J., and Stanton, G.P., 1999, The Savoy

Experimental Watershed-Early lessons for hydrogeologic modeling from a wellcharacterized karst research site, in Palmer, A.N., Palmer, M.V., and Sasowsky, I.D., eds., Karst modeling: Special Publication 5, Karst Waters Institute, Charles Town, WV, p. 247-254.

Brahana, J.V., Tennyson, Rodney, Terry, Jim, Hays, P.D., Pollock, Erik, 2009, Reactivated basement faulting as a hydrogeologic control of hypogene speleogenesis in the southern Ozarks of Arkansas, USA, in Stafford, Kevin, ed., Advances in hypogene karst studies: National Cave and Karst Research Institute Symposium 1, p. 99-110.

Brion, G., Brye, K., Haggard, B., West, C., and Brahana, V., 2010, Land-use effects on water quality of a first-order stream in the OzarkHighlands, mid-southern United States: River Research and Applications, DOI: 10.1002/rra.1394, 19 p.

Daigh, A.L., Brye, K.R., Sharpley, A.N., Miller, D.M., West, C.P., and Brahana, J.V., 2009, Fiveyear change in soil profile chemical properties as affected by broiler litter application rate: Soil Science, v. 174, no. 10, DOI: 10.1097/SS.0b013e3181bdbdb3, p. 531-542.

Davis, R.K., Brahana, J.V., and Johnston, J.S., 2000, Ground water in northwest Arkansas: Minimizing nutrient contamination from nonpoint sources in karst terrane: Arkansas Water Resources Center, University of Arkansas, Fayetteville, $59 \mathrm{p}$.

Funkhouser, J.E., Little, P.R., Brahana, J.V., Kresse, T.M., Anderson, M., Formica, S., and Huetter, T., 1999, Methodology to study the effects of animal production in mantled karst aquifers of the southern Ozarks, in Palmer, A.N., Palmer, M.V., and Sasowsky, I.D., eds., Karst modeling: Special Publication 5, Karst Waters Institute, Charles Town, WV, p. 255-258.

Gouzie, D., Dodd, R., and White, D., 2010, Dye tracing studies in southwestern Missouri, USA: Indication of stratigraphic flow control in the Burlington Limestone: Hydrogeology Journal, v. 18, no. 4, p. 1043-1052.
Hobza, C.M., Moffit, D.C., Goodwin, D.P., Kresse, Timothy, Fazio, John, Brahana, J.V., and Hays, P.D., 2005, Ground-water quality near a swine waste lagoon in a mantled karst terrane in northwestern Arkansas, in Kuniansky, E.L., 2005, U.S. Geological Survey Karst Interest Group Proceedings, Rapid City, South Dakota, September 12-15, 2005: U.S. Geological Survey Scientific Investigations Report 2005-5160, p. 155-162.

Imes, J.L, and Emmett, L.F., 1994, Geohydrology of the Ozark Plateaus aquifer system in parts of Missouri, Arkansas, Oklahoma, and Kansas: U.S. Geological Survey Professional Paper 1414-D, 127 p.

Jarvie, H.P., Sharpley, A.N., Brahana, Van, Simmons, Tarra, Price, April, Neal, Colin, Lawlor, A.J., Sleep, Darren, Thacker, Sarah, and Haggard, B.E., 2014, Phosphorus retention and remobilization along hydrological pathways in karst terrain: Environmental Science \& Technology, 28 p. [in review with journal].

Leh, M.D., Chaubey, I., Murdoch, J.F., Brahana, J.V., and Haggard, B.E., 2008, Delineating runoff processes and critical runoff source areas in a pasture hillslope of the Ozark Highlands: Hydrological Processes, Wiley Interscience, DOI: 10.1002/hyp7021, 15 p.

Luhmann, A., Covington, M., Alexander, S., Chai, S., Schwartz, B., Groten, J., and Alexander, E., Jr., 2012, Comparing conservative and nonconservative tracers in karst and using them to estimate flow path geometry: Journal of Hydrology, v. 448-449, p. 201-211.

Marshall, David, Brahana, J.V., and Davis, R.K., 1998, Resuspension of viable sediment-bound enteric pathogens in shallow karst aquifers, in Brahana, J.V., Eckstein, Yoram, Ongley, L.K., Schneider, Robert, and Moore, J.E., 1998, eds., Gambling with groundwater-Physical, chemical, and biological aspects of aquiferstream relations: Proceedings of the International Association of Hydrogeologists, Congress XXVIII, and the Annual Meeting of the American Institute of Hydrology, Las Vegas, p. 179-186.

Mott, D.N., Hudson, M.R., and Aley, T., 2000, Hydrologic investigations reveal interbasin recharge contributes significantly to detrimental nutrient loads at Buffalo National River, Arkansas: Proceedings of Arkansas Water Resources Center Annual Conference MSC-284, Fayetteville, AR., p. 13-20. 
Quinlan, J.F., 1989, Ground-water monitoring in karst terranes: Recommended protocols and implicit assumptions: U.S. Environmental Protection Agency, Research and Development, 600/X-89/050, 88 p.Peterson, E.W., Davis, R.K., and Brahana, J.V., 2000, The use of regression analysis to predict nitrate-nitrogen in springs in northwest Arkansas, in Sasowsky, I.D., and Wicks, C.M., eds., Groundwater flow and contaminant transport in carbonate aquifers: A.A. Balkema, Rotterdam, p. 43-63.

Peterson, E.W., Davis, R.K., Brahana, J.V., and Orndorff, H.O., 2002, Movement of nitrate through regolith covered karst terrane, northwest Arkansas: Journal of Hydrology, v. 256, p. 3547.

Sauer, T.J., Alexander, R.B., Brahana, J.V., and Smith, R.A., 2008, The importance and role of watersheds in the transport of nitrogen, in Follett, R.F., and Hatfield, J.L., eds., Nitrogen in the environment: Sources, problems, and management (2d ed.), chap. 8, p. 203-240.

Sheam, Ian, 2012, Whose side is the American Farm Bureau on?: Food and Environment Reporting Network, 5 p.

Steele, K.F., Davis, R.K., Brahana, J.V., Godfrey, Lyle, and Tatom, Ginger, 2002, Research and regulatory water-quality perspectives, Ozark Mountain Region, Arkansas: American Water Resources Association, Ground Water/Surface Water Interactions, p. 199-204.

Tennyson, Rodney, Terry, Jim, Brahana, Van, Hays, Phil, and Pollock, Erik, 2008, Tectonic control of hypogene speleogenesis in the southern Ozarks-Implications for NAQQA and beyond, in Kuniansky, E.L., ed., U.S. Geological Survey Karst Interest Group Proceedings, Bowling Green, Kentucky, May 27-29, 2008: U.S. Geological Survey Scientific Investigations Report 2008-5023, p. 37-46.

U.S. Geological Survey, 2010, USGS water-quality sampling: Standard protocols and procedures: U.S. Geological Survey Fact Sheet, National Monitoring Conference, NWQMC, available at http://pubs.water.usgs.gov/twri9A.

Varnel, C.J., and Brahana, J.V., 2003, Neuse RiverImpact of animal production on water quality, in Stewart, B.A., and Howell, Terry, eds., The Encyclopedia of Water Science: New York, Marcel Dekker, Inc., p. 622-624. 


\title{
An Initial Investigation of Hydrogeology and Water Quality of Big Creek in the Buffalo River Watershed near a Major Concentrated Animal Feeding Operation
}

\author{
By Victor L. Roland II ${ }^{1}$, Tyler Wright ${ }^{1}$, J. Van Brahana ${ }^{1}$, and Phil D. Hays ${ }^{1,2}$ \\ ${ }^{1}$ University of Arkansas, Department of Geosciences, Ozark Hall 216, Fayetteville, AR 72701 \\ ${ }^{2}$ U.S. Geological Survey, Arkansas Water Science Center, 401 Hardin Rd., Little Rock, AR 72211
}

\begin{abstract}
A swine concentrated animal feeding operation (CAFO) in Newton County, Arkansas near the Buffalo River was approved, permitted, and constructed in 2012. The CAFO is adjacent to Big Creek, which is a major tributary of the Buffalo River. The region has a mature karst landscape, which provides rapid recharge to groundwater. Groundwater and surface-water interaction within the Big Creek watershed is extensive, raising concerns over potential contamination of surface water or groundwater. Contamination pathways associated with CAFOs include leakage and lagoon overflow, preferential flow paths through the soil, and nutrient-rich runoff from manure application fields. Contaminants of concern are nutrients, pathogens, sediment, and trace metals. The objective of this project was to provide preliminary data on water-quality conditions in the Big Creek basin associated with the CAFO drainage area. Water samples were collected from Big Creek, natural springs, and private wells during base-flow conditions in July and August 2013. Sampling was conducted before initial application of CAFO waste effluent to fields in the watershed designated for manure application. Analyses of dissolved solutes indicated calcium-bicarbonate as the predominant water type in the study area. Calcium-bicarbonate-type water is indicative of dissolution of Boone Formation limestone, which crops out in the study area. Biological data show Escherichia coli and total coliform concentrations ranged from $<1.0-980$ Most Probable Number counts per 100 milliliters (MPN/100mL) and from <1.0-241,900 MPN/100mL, respectively. The wide range of Escherichia coli and total coliform concentrations may result from smallscale CAFOs, wildlife, and anthropogenic sources in the water; however, more data are necessary to elucidate sources of bacteria in groundwater and surface water. Nutrient concentrations varied spatially with no discernible trend; however, phosphorus and nitrate concentrations were elevated in groundwater samples relative to surface-water samples. Preliminary data from this study show the variability in chemical and biological water quality in the study area, and provide background information necessary for future assessments of potential changes in water quality in the Big Creek watershed as the CAFO becomes fully operational.
\end{abstract}




\title{
A Method to Investigate Karst Groundwater Flow in Nash Draw, Eddy County, New Mexico, to Delineate Potential Impacts of Potash Industry Discharge and Runoff
}

\author{
By James Goodbar ${ }^{1}$, and Andrea Goodbar ${ }^{2}$ \\ ${ }^{1}$ Bureau of Land Management, 620 E. Greene St., Carlsbad, NM 88220 \\ ${ }^{2}$ Central New Mexico Community College, 3027 Derrick Rd., Carlsbad, NM 88220
}

\begin{abstract}
Nash Draw is a karst valley approximately 15 miles east of Carlsbad, New Mexico. It is the site of several potash mines - one has been operating since the early 1930s. During that time a significant amount of refining brine waste has been disposed of into the valley. The geology and hydrology of Nash Draw have been studied extensively in relation to the potash industry, the Gnome Project, and the Waste Isolation Pilot Plant. All studies agree that the karst nature of Nash Draw plays an important role in the overall hydrology of the area. Specific studies suggest that the brine effluent of the potash industry may be causing dramatic changes in the ecosystem associated with the draw. To date, there have been no quantitative (or qualitative) studies to delineate specific flow paths in this complex hydrologic system. A quantitative water-tracing study may supply a critical piece of information in understanding the complexities and flow paths of the karst groundwater system in Nash Draw. It would also provide useful information for environmental assessments and impact statements necessary in making responsible resource management decisions related to the potash industry and the Nash Draw ecosystem.
\end{abstract}

\section{SETTING AND BACKGROUND}

Nash Draw is a karst subsidence valley in southeastern New Mexico that is 4 to 6 miles wide, 22 to 23 miles long, and covering about 128 square miles (fig. 1 ). The average depth ranges from 100 to 200 feet. It generally runs from the north-northeast to the south-southwest, and is bound on the north by the Maroon Cliffs, on the west by Quahada Ridge, on the east by Livingston Ridge, and on the south by the Pecos River. More than 100 collapsed sinks and cave entrances have been documented in the bottom of the valley. Dissolution takes place primarily in the Rustler and the Salado Formations of Permian age. At Nash Draw, the Rustler consists of interbedded sulfates, dolomites, and mudstones while the Salado is primarily halite with minor sulfate beds. At the lower end of Nash Draw are a series of seven shallow lakes or playas. The presumed base level of the Nash Draw hydrologic system is the Pecos River due to the increased salt content in the Pecos River below Nash Draw at Malaga Bend (fig. 1).

Potash mining has been operating along the flanks of Nash Draw since the early 1930s (Brokaw and others, 1972). Tailings ponds were established in the margins of the draw and mining fluids have been intermittently discharged into the karst valley as a result of dike breaches and/or releases of brine fluids to avoid catastrophic dike failure. Sinkholes have formed in the bottom of tailings ponds draining the brine tailings into the subsurface. Large sinkholes have developed in salt tailings piles, suggesting a direct release of at least some of the waste directly to the subsurface conduits with eventual discharge at downstream locations. Several of the natural playas on the south end of Nash Draw have progressively become more and more salty over the decades. This has resulted in some of the playas becoming unsuitable for certain species of plants and wildlife that previously inhabited them.

\section{Previous Studies}

Geologic and hydrologic studies conducted in Nash Draw over the decades have attempted to accurately describe the geology and characterize groundwater flow. Most of the studies acknowledge that the solution activity and associated collapse, subsidence, and fracturing have increased the permeability of the overlying rock members and increased the hydrologic communication between formations. The earliest of these works by Willis T. Lee 
(1925) describes "erosion by solution and fill." After the discovery of potash in the area, Robinson and Lang (1938) published an early paper on the geology and hydrology of Nash Draw. This study identified the brine aquifer at the top of the Salado running down the

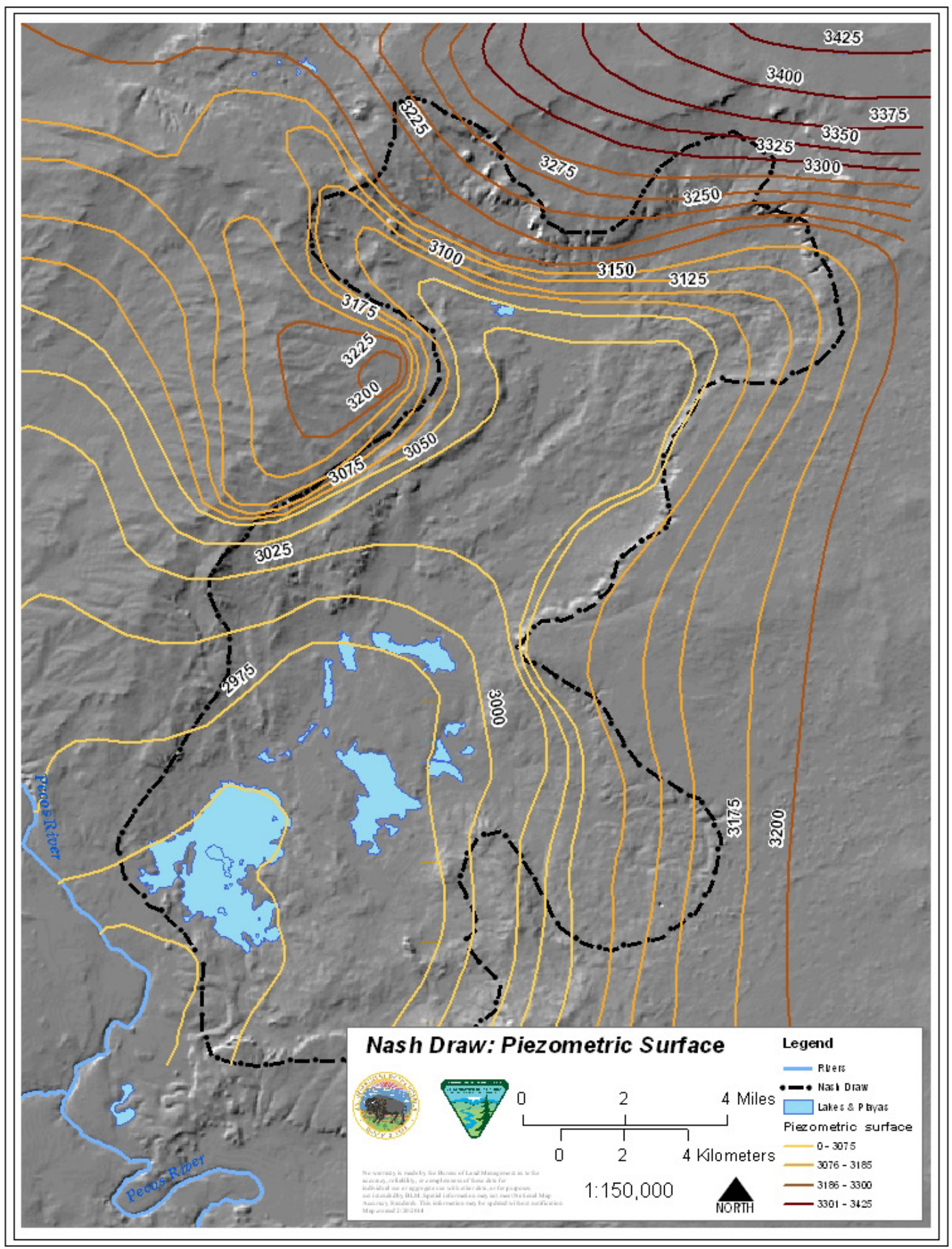

Figure 1. Nash Draw boundary and potentiometric surface at the top of the brine aquifer. 
length of Nash Draw to the Pecos River. Hendrickson and Jones (1952) also noted that the brine aquifer moves under the Salt Lake and discharges into the Pecos River near Malaga Bend. A landmark report was written by James Vine on behalf of the Atomic Energy Commission to study the surface geology of Nash Draw in preparation for the Gnome Project, the detonation of a nuclear device for peaceful purposes (Vine, 1962). His report was one of the first comprehensive works on the geology of Nash Draw and included the first detailed geologic map of Nash Draw. He describes Nash Draw and the lakes on the south end as having no external surface drainages or outlets. Brokaw and others (1972) reported comprehensively on the geology and hydrology of the Carlsbad potash area as background for siting a repository for nuclear waste.

Geohydrology Associates (1978) was contracted by the Bureau of Land Management (BLM) to specifically study the effects of potash industry brine disposal on the limited quantities of fresh water in the area. They were asked to address three questions: 1) is fresh water in the Carlsbad potash area in danger of contamination from expanded potash mining activities, 2) is the brackishness of the Pecos River below Malaga Bend due to mining activity, and 3 ) is the amount of leakage from brine-disposal ponds significant compared to the volumes of naturally occurring brine? This study was followed up by a second study by the same company (Geohydrology Associates, 1979) to address other objectives: 1) establish the depth and configuration of the water table in the potash area, 2) measure aquifer parameters in the potash area, 3) refine the hydrologic parameters used in water-budget studies in order to establish more accurate inflow-outflow relations at various plant sites, and 4) evaluate the suitability of several natural salt lakes as brine-disposal sites. Geohydrology Associates (1979, p. 86) concluded that leakage from the Salt Lake "may discharge into the Pecos River" and that groundwater quality and levels have been affected by potash-refinery waste disposal. Bachman (1981, 1987) postulates that Nash Draw has taken its present form as a result of the coalescing of collapse sinkholes. Powers and Owsley (2003) identified numerous cave and karst features during a study along the realignment of Highway 128 where it crosses Nash Draw, concluding that karst processes are still active in that area. Powers and others (2006) brought many of these studies together in their paper on Nash Draw evaporite karst features and processes. They also suggest that brine water of Laguna Grande may be infiltrating sediments in a low divide known as Scoggin Flat. Powers and others (2006) also cite the lack of quantifiable data in being able to differentiate springflows into the lagunas and calculate storage capacities in the karst hydrologic system.

All authors agree that karst processes are at work in Nash Draw and acknowledge that the underground transport of water and subsequent solution and collapse of the evaporite formations, with attendant erosion, is responsible for the development of the karst valley. The extent of influence that karst conduit flow has on the system and the potential impacts to the downstream ecosystems are still not understood.

This is an abbreviated account of geological and hydrological studies of Nash Draw. A few additional background references include Bachman and Johnson (1973), Hale and others (1954), Cooper and Glansman (1971), and Mercer (1983). Numerous more detailed articles and documents have been produced for Project Gnome, the Waste Isolation Pilot Plant (WIPP), and industrial interests in the area.

\section{Climate}

The area has an arid to semiarid climate. The average rainfall is between 25 and 35 centimeters (9-12 inches) per year. The average monthly maximum temperatures in July range from 34.5 to $36.5{ }^{\circ} \mathrm{C}\left(94\right.$ to $\left.98{ }^{\circ} \mathrm{F}\right)$ with average monthly minimums of -2 to $-1{ }^{\circ} \mathrm{C}$ ( 28 to $31^{\circ} \mathrm{F}$ ) in December and January. Average annual potential evaporation rates far exceed average annual precipitation. Evaporation rates approach 13,400 cubic meters per hectare (4.4 acre-feet per year) in the brine ponds of this area, resulting in a large moisture deficit. Lesser evaporation rates can be attributed to spoil piles, mud flats, bare soil, and plant transpiration (Geohydrology and Associates, 1978, p. 60). 


\section{GEOHYDROLOGY}

The Nash Draw area contains Permian-age evaporites of the Rustler and Salado Formations. In this area, the Rustler is primarily made up of interbedded sulfates, dolomites, and mudstone/siltstones while the Salado is composed of 75 percent halite (fig. 2). A potentiometric surface map on top of the brine aquifer (fig. 1) was developed by Geohydrology Associates (1979), but it contains uncertainties inherent in all such maps regarding specific flow paths in karst terrain such as Nash Draw.

Within the Rustler Formation from the top units to the bottom (fig. 2), the members are the Forty-niner, the Magenta Dolomite, the Tamarisk, the Culebra Dolomite, and the Los Medaños, an interbedded unit of sandstone, siltstone, and sulfate.

The Forty-niner is $12-19$ meters (40-65 feet) thick and is composed primarily of sulfate with lesser amounts of mudstone. Where exposed the Forty-niner also contains well developed cave systems that, at times, reach the Magenta (Goodbar, 2013).

The Magenta is 6-9 meters (20-30 feet) thick, composed of dolomite and sulfate, and can be identified in outcrop by its color, weathering to a pink to pale-red. The dolomite is alternately laminated with yellowish-green anhydrite or gypsum. The Magenta is water-bearing in the Nash Draw area, with generally very low production.

The Tamarisk in Nash Draw is 35 meters (115 feet) thick and largely composed of sulfate (gypsum in Nash Draw) that can be coarsely crystalline where exposed at the surface; these sulfate beds are laterally continuous downdip to the east out of Nash Draw where they are anhydrite. The Tamarisk also contains caves and swallets in the floor of Nash Draw where water can be channeled into subsurface conduits (fig. 3) or sink slowly into them where sinkholes are covered by soil layers (fig. 4). The two sulfate beds of the Tamarisk (A-2 and A-3, fig. 2) are separated by a mudstone unit (M-3) in Nash Draw and nearby surrounding areas.

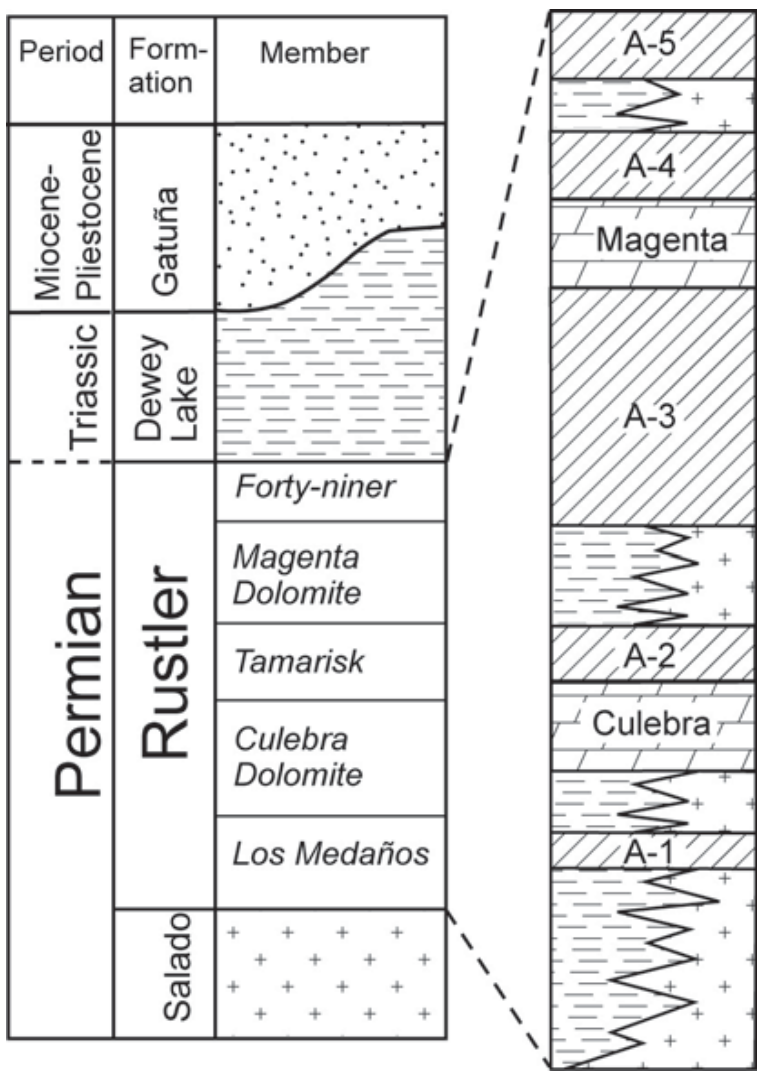

Figure 2. Basic stratigraphic units in Nash Draw (modified from Powers and others, 2006). Each of the mudstone/siltstone units has halite or halitic facies equivalents east of Nash Draw.

The Culebra is a microcrystalline gray dolomite approximately 9 meters (30 feet) thick, containing numerous small spherical cavities and having high porosity (Vines, 1963, p. 1318). The Culebra also contains the lower aquifer of the Rustler.

Below the Culebra Dolomite is the Los Medaños Member (Powers and Holt, 1999). It is composed of mainly siltstone and mudstone, but also includes sulfate beds as well as halitic to halite intervals to the east of Nash Draw. 


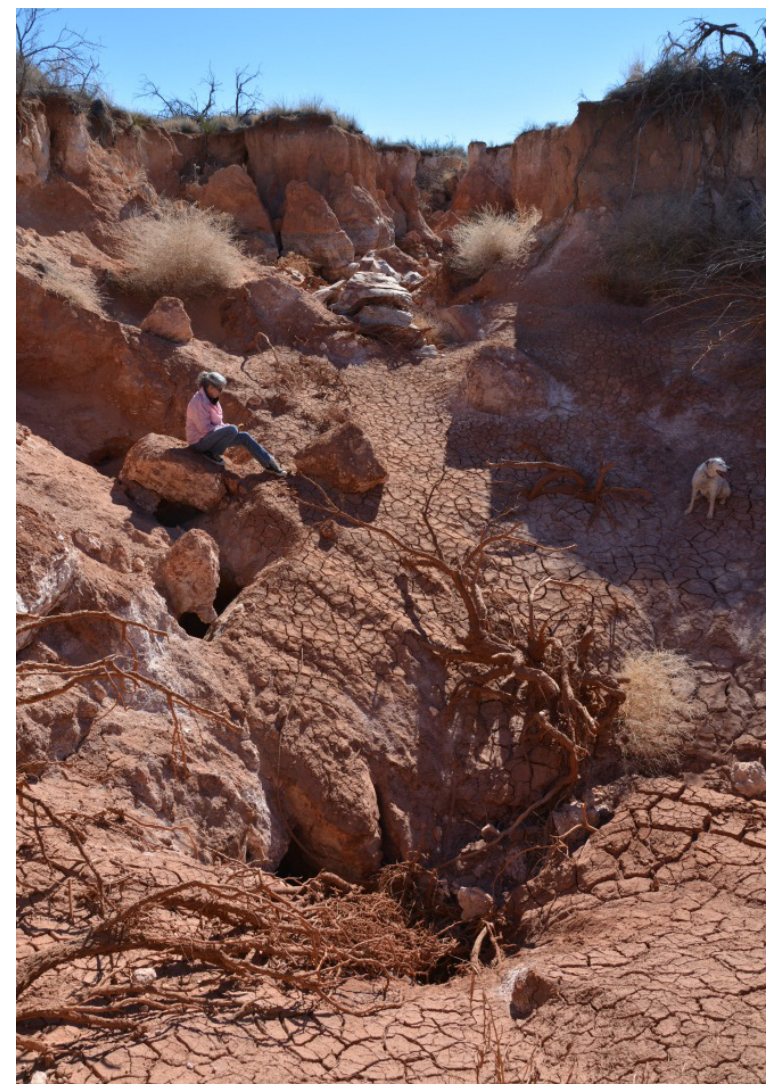

Figure 3. Cave entrances in the bottom of Nash Draw create point sources for aquifer recharge.

The Salado Formation is composed of thick beds of halite and thinner beds of sulfate (commonly anhydrite with lesser amounts of polyhalite). At Nash Draw, the upper section consists of variably consolidated clay and reddish-gray to brown silt with varying amounts of gypsum that may be brecciated. This layer is thought to be the insoluble residue left over from the solution of halite in the upper part of the Salado. It is through this breccia, resting on top of undissolved Salado halite, that the brine aquifer flows (Vine, 1963, p.7-8).

The two primary aquifers in Nash Draw are the brine aquifer in the solution breccia at the top of the Salado and the Culebra Dolomite. Other upper members of the Rustler, such as the Magenta and Forty-Niner, may also contribute to the overall water input and can be considered as hydrologically connected over parts of Nash Draw due to extensive dissolution and associated collapse, subsidence, and fracturing (Brokaw and others, 1972, p. 54).

\section{WATER TRACING}

The purpose of conducting a water tracing project in Nash Draw would be to determine 1) where water goes once it enters the subsurface, 2) what the water budget is for the hydraulic system when factoring in the potash mining discharge rates, 3) the extent conduit flow contributes to the overall groundwater flow in Nash Draw, and (4) the residence times and flow rates within the system. The concerns prompting such a study are the same as those identified in the 1970s; do salts from potash operations enter the natural lakes and depressions in Nash Draw and the Pecos River in sufficient quantities to create undesirable impacts to the ecosystem?

Conventional hydrologic and hydrogeologic methods of groundwater modeling often do not provide accurate results when applied to karst. Karst-specific methods are needed to more accurately characterize flow and transport in conduit networks (International Association of Hydrogeologists, 2013).

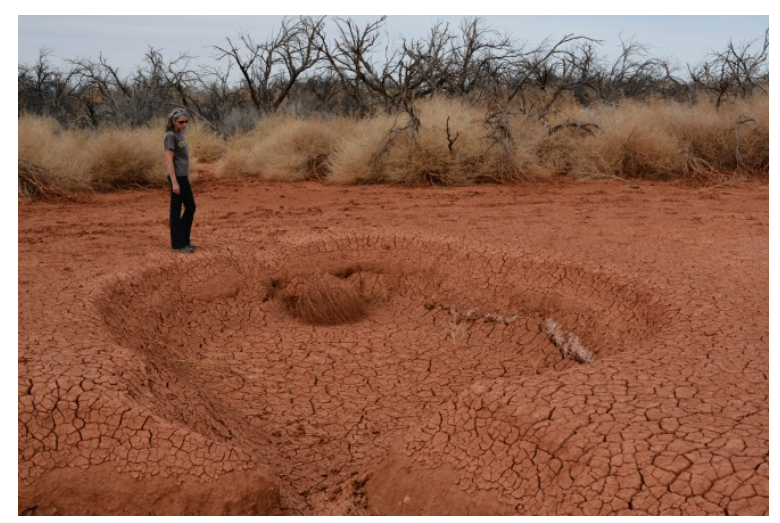

Figure 4. Alluviated sinkholes provide slow infiltration of runoff into the subsurface.

Groundwater tracing has long provided the detailed point-to-point connection information in complex hydrologic systems where the exact nature of interactions between the hydrologic and geologic settings is difficult to determine. This is particularly the case in karst terrains. A groundwater trace would provide a more empirical and definitive study needed to identify point-to-point connections in the Nash Draw karst groundwater system. This will help managers better understand the dynamics and interactions of that complex system and the potential impacts to a properly functioning 
ecosystem. Figure 5 shows a generalized cross section of Nash Draw and the relation between geologic members and the hydrologic system.

It is widely held that in order to obtain the most useful information, it is much more effective to conduct a quantitative trace than a qualitative trace. Field (2002) showed that quantitative tracing studies provide detailed information about flow dynamics. This is done by developing a tracer budget and plotting the amount of tracer injected with the amount of tracer recovered over time while factoring in groundwater discharge. This is referred to as a breakthrough curve. The use of qualitative tracing methods is good to establish positive connections between input sources and monitoring points. Qualitative methods may also be used to estimate flow rates. They are not designed to determine how much of the tracer material is escaping past the monitoring locations and into other parts of the hydrologic system. Using a quantitative tracing method can give a better idea of how significant an amount of tracer is moving into unmonitored locations. Quantitative tracer studies can also provide better data about mean residence time, flow rates, and dispersion. This information allows for better analysis and evaluation of the hydrologic system's divergence, convergence, dilution, and storage properties.

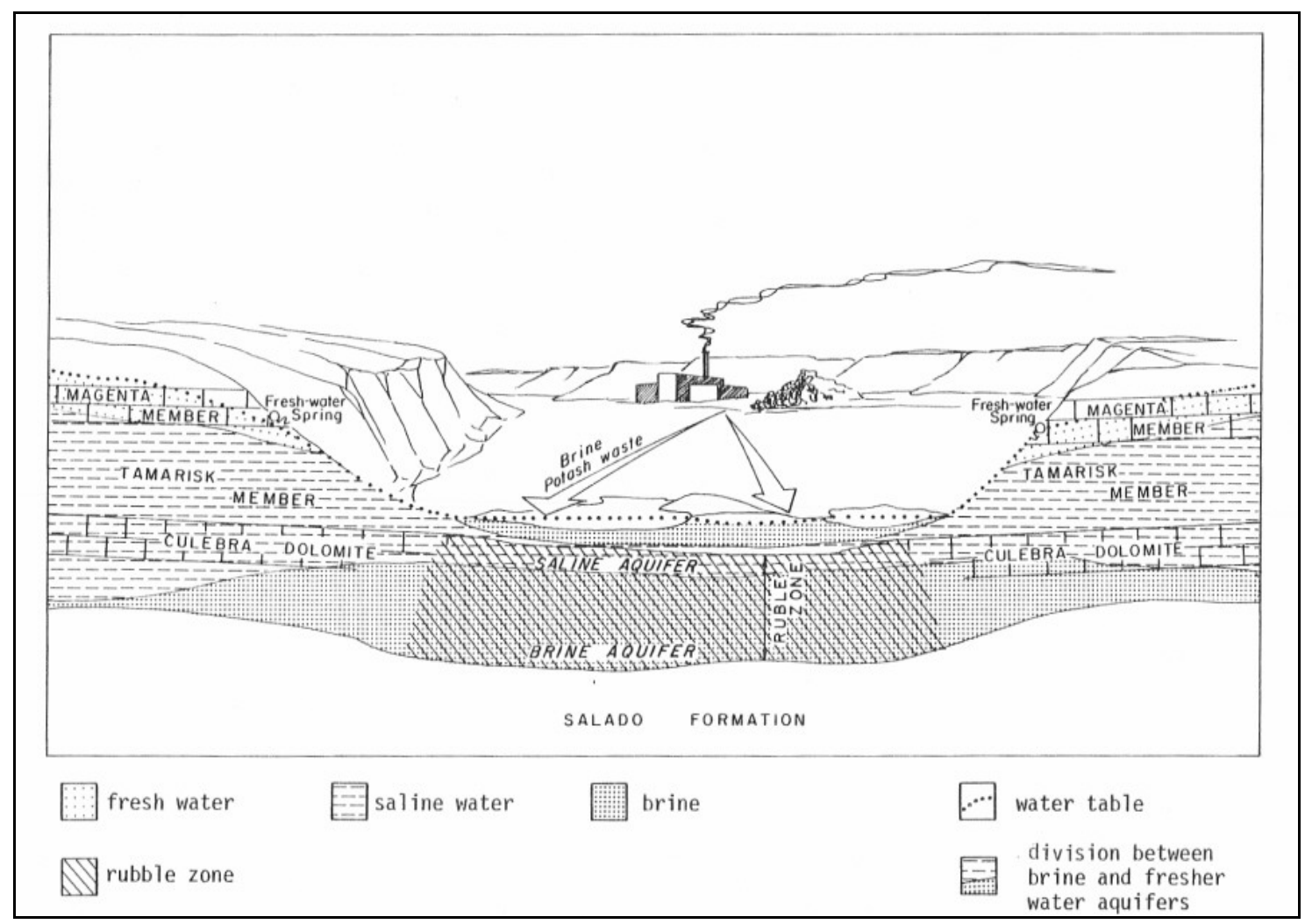

Figure 5. Generalized cross section of Nash Draw showing geologic and hydrologic relations (From Geohydrology Associates, 1979). There are no current "fresh water springs" along the margins of Nash Draw at the Magenta outcrops.

The first phase of the project would begin in the lower reaches of Nash Draw at its terminus near the Pecos River and include the Mosaic potash mine tailings piles/discharge points. The second phase would move up Nash Draw to its northern reaches and include the Intrepid potash mine tailings piles/discharge points (fig. 6).
There are several factors to consider when initiating a water-tracing project. These include 1) using the appropriate tracer for the environment, 2) using a sufficient amount of tracer, 3) how the tracer will be introduced into the hydrologic system, 4) sampling techniques and locations, and 5) the analysis and interpretation of the data. 
The first of these factors is using the appropriate tracer for the environment at hand, as some tracers may not perform well or give the desired results due to specific water chemistry, geologic conditions, and other variables.

Another factor is using a sufficient amount of tracer to ensure that the trace will be successful, which requires understanding the potential water quantities in the aquifer and the potential for loss of the tracer.
The next factor is how the tracer will be introduced into the hydrologic system. In karst terrains, entry points may be natural sinkholes, swallets, cave entrances, or other surface features such as lakes or other man-made impoundments. Input point sources may also occur from collapse of closed depressions into conduits below.

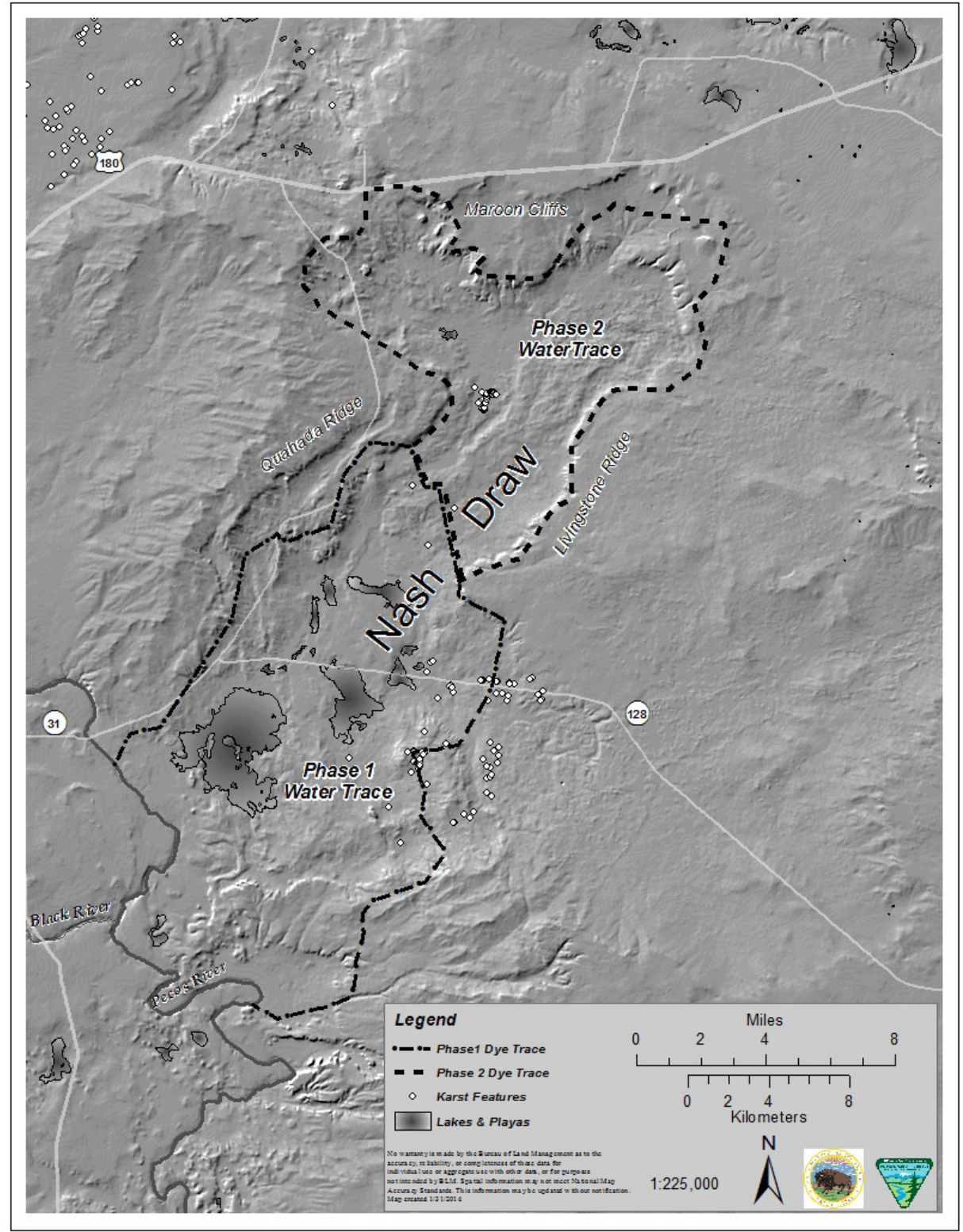

Figure 6. Proposed dye traces and boundaries: Phase 1 and Phase 2 showing cave and karst features. 
This can be a relatively common occurrence in the natural world but may be exacerbated when closed depressions are used for solid or fluid storage. Tracers can be introduced in liquid form or as a solid (powder). In areas where rainfall is low and water flow is limited, tracers may need to be flushed into the system using large water tankers, although this may be impractical in some situations.

A forth factor is that of selecting the appropriate techniques and locations, which become a critical part of tracer project design. Sampling locations should be selected carefully.

Multiple background samples should be taken prior to the introduction of any tracer into the system. Background concentrations can adversely affect tracer analysis if not recognized and taken into account. There are a large number of both naturally occurring and man-made materials and substances that can affect accurate tracer analysis. Due to this, it becomes critically important to be able to subtract those background concentrations from subsequent samples to obtain more accurate tracer results (Field, 2011). This ensures there is no cross contamination from other sources that may give false data. The method(s) of sampling are also critical to the success of a tracer test. The use of continuous autosamplers, activated carbon receptors or intermittent grab samples makes a difference in the quality of data gathered and the reliability of the test.

A final and critical point is having proper analysis and interpretation of the data. A poor or inadequate analysis can taint the results of the test and cause the trace to lose credibility. Choosing a laboratory that maintains high standards and reliability can make the difference between a successful trace or not (Aley, 2002). A proper analysis requires both experience in interpreting tracer tests and modeling breakthrough curves. Multiple peaks on breakthrough curves may indicate multiple flow channels or conduits that have been partially constricted, forcing flow to diverge into auxiliary channels. It could also mean that there were some areas in which the flow was held in detention pools or in waterfall plunge pools. In such cases the use of a multi-dispersion model and dual-advection dispersion equations may provide for a more accurate interpretation (Field, 2012). Together the collective data will provide a much more detailed picture of the hydrologic system.

\section{APPLIED SCIENCE AND ADAPTIVE MANAGEMENT}

Once a water trace has been conducted and the data analyzed and interpreted it should provide a much clearer understanding of the hydrologic system from which to make resource management decisions. Options and alternatives for proposed actions involving mine operations can be analyzed from a knowledge-based standpoint and potential outcomes can be more accurately predicted. Through a better understanding of this complex hydrologic system the BLM in conjunction with the potash industry can develop better mitigation and monitoring plans and reach a finer balance between resource use and resource protection. With a clearer picture of the groundwater flow system in Nash Draw, adaptive management strategies can be generated to react to undesirable events and changes in mine operations. Knowing the point-to-point flow paths and probable impacts downgradient should help guide management decisions and avoid future adverse impacts to the environment. In the long term, higher quality water flowing through the system will provide better water quality and habitat for the collective ecosystems.

The BLM Carlsbad Field Office maintains and manages geographic information system (GIS) data used within the land management agency. Data generated through the course of an investigation such as this could be maintained and managed for ease of retrieval for further analysis. It could be combined with existing spatial data as well as analytical data such as land use, well pumping and recharge, evapotranspiration, surface-water flow, stream networks, digital elevation models (DEMs) and geology. This will allow the BLM to create new groundwater models and information for environmental assessments.

Resource management issues could be addressed using 3-D hydrogeological models, groundwater level and quality spatial 
information products that show the area of critical interest, and animations that show groundwater changes and movement through time.

\section{SUMMARY}

Nash Draw is a karst valley approximately 15 miles east of Carlsbad, New Mexico. It is formed in the Rustler Formation of Permian age as a result of dissolution and collapse of dolomite and sulfate beds within the formation. There are two aquifers within the system. One aquifer is in the Culebra Dolomite and the other is a brine aquifer at the base of the Rustler and in the top of the Salado Formations. Nash Draw has been the site of several potash mines since the 1930s. Three tailings piles and brine ponds are located along the edges of Nash Draw. Brine pond leakage has been an acknowledged occurrence since the industry began their disposal operations. There have been multiple events over the decades where brine ponds have breached and sinkholes have opened up in tailings piles and brine ponds, diverting their contents into subsurface conduits. The natural playas at the lower end of Nash Draw have been getting more and more salty. Species of plants and wildlife can no longer survive the salt concentrations. There have been no conclusive studies to determine where water or potash industry discharge goes once it enters the karst conduit system. There is speculation that fluids entering the aquifer may go into the natural playas and the Pecos River.

A primary method of determining subsurface connections and transport rates, particularly in karst areas, is through the use of water-tracing techniques. The use of water tracers has been used very successfully for decades and has proven to give reliable results. The most efficient way to gather sufficient data to answer the critical questions needed to make informed management decisions regarding future discharge and retention of potash industrial discharge would be to conduct a quantitative water trace rather than a qualitative trace. This would provide the BLM with the information needed to make decisions and develop best management practices based on the best available science and verifiable results.
The use of GIS as a method of tracking and analyzing data would provide a long-term rapid retrieval system for the data. It could also be used as a groundwater modeling tool for future studies and in developing future adaptive management strategies.

\section{ACKNOWLEDGMENTS}

The authors thank Dr. Malcolm Field and Dr. Dennis Powers for their constructive reviews and comments, which greatly improved the manuscript. The authors also thank Shiva Achet, David Herrell, and Ruben Rodriguez for their reviews, comments, and GIS assistance.

The views expressed in this paper are solely those of the authors and do not necessarily reflect the views or policies of the BLM.

\section{REFERENCES}

Aley, Thomas, 2002, Groundwater tracing handbook: Ozark Underground Laboratory, Protem, Missouri, USA, 44 p.

Bachman, G.O., 1981, Geology of Nash Draw, Eddy County, New Mexico: U.S. Geological Survey Open-File Report 81-31, 10 p., 4 pl.

Bachman, G.O., 1987, Karst in evaporites in southeastern New Mexico: Sandia National Laboratories, SAND84-7178, p. 38-41.

Bachman, G.O., and Johnson, R.B., 1973, Stability of salt in the Permian Salt Basin of Kansas, Oklahoma, Texas, and New Mexico: U.S. Geological Survey Open-File Report 73-14, $62 \mathrm{p}$.

Brokaw, A.L., Jones, C.L., Cooley, M.E., and Hays, W.H., 1972, Geology and hydrology of the Carlsbad potash area, Eddy and Lea Counties, New Mexico: U.S. Geological Survey Open-File Report 72-49, 86 p.

Cooper, J.B., and Glanzman, V.M., 1971, Geohydrology of project Gnome site, Eddy County, New Mexico: U.S. Geological Survey Professional Paper 712-A, 24 p.

Field, M.S., 2002, The QTRACER2 program for tracer-breakthrough curve analysis for tracer tests in karst aquifers and other hydrologic systems: U.S. Environmental Protection Agency /600/R-02/001, 179 p.

Field, M.S., 2011, Application of robust statistical methods to background tracer data characterized 
by outliers and left-censored data: Water Research, v. 45, p. 3107-3118.

Field, M.S., and Feike, J.L, 2012, Solute transport in solution conduits exhibiting multi-peaked breakthrough curves: Journal of Hydrology, v. 440-441, p. 26-35.

Geohydrology Associates, 1978, Ground-water study related to proposed expansion of potash mining near Carlsbad, New Mexico: Bureau of Land Management, Contract YA-512-CT7-217, p. 1-2.

Geohydrology Associates, 1979, Water-resources study of the Carlsbad potash area, New Mexico: Bureau of Land Management, Contract YA-512CT8-195, 86 p.

Goodbar, J.R., 2013, Solution mining and the protection of karst groundwater supplies in Burton Flats, southeast New Mexico, USA, in Land, L., ed., Proceedings of the $20^{\text {th }}$ National Cave and Karst Management Symposium, p. 1317.

Hale, W.E., Hughes, L.S., and Cox, E.R., 1954, Possible improvement of quality of water of the Pecos River by diversion of brine at Malaga Bend, Eddy County, New Mexico: Pecos River Commission, 43 p., 8 pl.

Hendrickson, G.E., and Jones, R.S., 1952, Geology and ground-water resources of Eddy County, New Mexico: New Mexico Bureau of Mines and Mineral Resources Ground-Water Report 3, $73 \mathrm{p}$.

International Association of Hydrogeologists, 2013, available online at http://karst.iah.org/karst_hydrogeology.html

Lee, W.T., 1925, Erosion by solution and fill, in Contributions to the geology of the United States: U.S. Geological Survey Bulletin 760-C, $107 \mathrm{p}$.

Mercer, J.W., 1983, Geology of the proposed waste isolation pilot plant site, Los Medanos area, southeastern New Mexico: U.S. Geological Survey Water-Resources Investigations Report 83-4016, 121 p.

Powers, D.W., Beauheim, R.L., Holt, R.M., and Hughes, D.L., 2006, Evaporite karst features and processes at Nash Draw, Eddy County, New Mexico, in Land, L., Lueth, V., Raatz, W., Boston, P., and Love, D., eds., Caves and karst of southeastern New Mexico: New Mexico Geological Society Fifty-seventh Annual Field Conference, p. 253-264.
Powers, D.W., and Holt, R.M., 1999, The Los Medanos Member of the Permian Rustler Formation: New Mexico Geology, v. 21, no. 4, p. 97-103.

Powers, D.W., and Owsley, D., 2003, Field survey of evaporite karst along New Mexico Highway 128 realignment routes, in Johnson, K.S., and Neal, J.T., eds, Evaporite karst and engineering/environmental problems in the United States: Oklahoma Geological Survey Circular 109, p. 233-240.

Robinson, T.W., and Lang, W.B., 1938, Geology and ground-water conditions of the Pecos River Valley in the vicinity of Laguna Grande de Sal, New Mexico: New Mexico State Engineer $12^{\text {th }}$ and $13^{\text {th }}$ Biennial Report, $89 \mathrm{p}$.

Vine, J.D., 1963, Surface geology of the Nash Draw quadrangle, Eddy County, New Mexico, in Contributions to general geology: U.S. Geological Survey Bulletin 1141-B, 46 p. 


\title{
Use of A Dual Continuum Model to Describe Solute Transport in Karst
}

\author{
By Roger Painter, Justin Harris, and Lonnie Sharpe \\ Tennessee State University, College of Engineering, 3500 John A Merritt Blvd., Nashville, TN 37209
}

\begin{abstract}
The advection dispersion equation (ADE) as applied to pipe flow often successfully models solute transport along major karst features. This approach has had success when flow within these features is predominantly along conduits. However, the slower solute transport associated with flow in the diffuse continuum may explain the tendency of tracer response concentration data to have a long upper tail compared to the diminishing tail predicted by the ADE. The hydraulic response of karst to a rain event also reflects the dual continuum for karst flow. The high permeability of the conduit network allows for a subsequent quick response at the spring to a rain event. A slow recession to pre-rain event springflow is often related to water being released from storage in the fractured media or epikarst. It is in this context that the case is made for a dual continuum transport model for karst. In existing double continuum models the matrix and the conduit network are each represented by a continuum, and the exchange of water between the two continua is governed by lumped exchange parameters. This paper presents a dual continuum model for karst, which is based on the finite element solution of the rigorous model in terms of the Navier-Stokes and continuity equations describing conduit flow, the Forchheimer-corrected Brinkman equations describing the diffuse phase flow, and finally, the transient ADE describing solute concentration. In the model, the two adjacent continua share a common boundary. Due to the extreme differences in the flow regimes near the common boundary, the boundary conditions are characterized by very steep gradients. Furthermore, the hydraulic characteristics are independent of the concentration of the diluted contaminant. To facilitate validation of the computational approach, a laboratory-scale analog model was constructed consisting of an open channel submerged in a porous media. The analog model allows the conduit cross section and the hydraulic conductivity of the porous media to be varied as parameters. The computer code, COMSOL 4.4 Forchheimer Flow Module, was modified to provide the steady state solution for the system (COMSOL user's manual, 2014), and the transient flow model with solute transport was developed using the FlexPDE 6.0 finite element solver (FlexPDE 6 user's manual, 2014).
\end{abstract}

\section{REFERENCES}

COMSOL user's manual, 2014, Introduction to COMSOL multiphysics: COMSOL Inc., Burlington, MA, USA, 158 p., website accessed on 3/12/2014, also available at http://www.comsol.com/shared/downloads/IntroductionToCOMSOLMultiphysics.pdf

FlexPDE user's manual, 2014, FlexPDE 6, version 6.35, Spokane Valley, WA, website accessed on 3/12/2014, also available at http://www.pdesolutions.com/download/flexpde635.pdf 


\title{
GEOCHEMISTRY
}

\section{Geochemical Evidence for Denitrification in the Epikarst at the Savoy Experimental Watershed, Northwest Arkansas}

\author{
By Jozef Laincz ${ }^{1}$ and Phil D. Hays ${ }^{2,3}$ \\ ${ }^{1}$ Environmental Dynamics, 216 Ozark Hall, University of Arkansas, Fayetteville, AR 72701 \\ ${ }^{2}$ University of Arkansas, Department of Geosciences, Ozark Hall 216, Fayetteville, AR 72701 \\ ${ }^{3}$ U.S. Geological Survey, Arkansas Water Science Center, 401 Hardin Rd, Little Rock, AR 72211
}

\begin{abstract}
Karst aquifers are highly vulnerable to agricultural nitrate $\left(\mathrm{NO}_{3}^{-}\right)$contamination due thin soils and rapid conduit flow characteristic of karst geology. Many karst regions contain epikarst, an upper weathered layer of carbonate bedrock, which could support a higher degree of denitrification, as a result of physical properties that are distinctly different from the underlying karst. This study aimed to identify denitrification and characterize controls on denitrification in a well-delineated epikarst system in northwest Arkansas. Water samples were collected at an interceptor trench and at epikarst springs downgradient from the trench after four storm events in the spring 2011 and analyzed for $\mathrm{NO}_{3}{ }^{-}$ concentration, $\mathrm{NO}_{3-}$ delta-nitrogen- $15\left(\delta^{15} \mathrm{~N}\right.$; ratio of nitrogen-15 $\left({ }^{15} \mathrm{~N}\right)$ :nitrogen $14\left({ }^{14} \mathrm{~N}\right)$ isotopes $)$ and delta-oxygen-18 $\left(\delta^{18} \mathrm{O}\right.$; ratio of oxygen-18 $\left({ }^{18} \mathrm{O}\right)$ :oxygen-16 $\left({ }^{16} \mathrm{O}\right)$ isotopes), dissolved organic/inorganic carbon ratio (DOC/DIC) concentration and delta-carbon-13 $\left(\delta^{13} \mathrm{C}\right.$; ratio of carbon-13 $\left({ }^{13} \mathrm{C}\right)$ :carbon-12 $\left({ }^{12} \mathrm{C}\right)$ isotopes), and dissolved gas concentration of nitrogen and oxygen $\left(\mathrm{N}_{2}, \mathrm{O}_{2}\right.$ respectively). Denitrification was indicated by an average $\mathrm{NO}_{3}$ - decrease of approximately fifty percent along the trench-spring flowpaths. For flowpaths upgradient from the trench, denitrification was indicated by simultaneous isotopic enrichment in $\mathrm{NO}_{3}{ }^{-}$with ${ }^{15} \mathrm{~N}$ and ${ }^{18} \mathrm{O}$ and by the trend of increasing DIC concentration with decreasing $\delta^{13} \mathrm{C}$ of DIC detected in the trench samples. The occurrence of denitrification in the system was corroborated by dissolved $\mathrm{N}_{2}$ measurements which showed supersaturation of up to one hundred-six percent in all except for three samples. Consistent with environmental requirements of denitrifiers, $\mathrm{N}_{2}$ saturation negatively correlated with $\mathrm{O}_{2}$ saturation and positively correlated with DOC concentration at the springs, with the latter suggesting a limiting role of DOC on denitrification in the epikarst. The results also suggest that hydrology (epikarst saturation) plays an important indirect role in controlling denitrification: more saturated conditions likely deliver more DOC substrate and more restrict $\mathrm{O}_{2}$ diffusion into the epikarst, thus helping to create an anoxic environment suitable for denitrification. In conclusion, this study successfully identified denitrification and several of its controls in the studied epikarst system, and its findings can serve as a foundation for future, quantitative studies.
\end{abstract}

\section{INTRODUCTION}

High nitrate $\left(\mathrm{NO}_{3}{ }^{-}\right)$concentrations in water pose a risk to human health (Tenovuo, 1986) as well as the health of aquatic ecosystems (Goolsby and Battaglin, 2001; Rabalais and others, 1996). The problem of groundwater $\mathrm{NO}_{3}{ }^{-}$ contamination is most often associated with agricultural activity, and one type of landscape especially vulnerable to such contamination is karst (Boyer and Pasquarell, 1996; Power and Schepers, 1989). Here, the typically thin or missing soil cover, direct point-recharge via sinkholes, and rapid, concentrated flow in the conduit network with little microbial remediation and high rates of dispersion offer little protection of aquifers from contamination originating at the surface. A case in point is the area under study, the karst region of northwest Arkansas, where intense animal production and excess nutrient generation have been linked to elevated $\mathrm{NO}_{3}{ }^{-}$concentrations in local springs and wells (Adamski, 1997; Davis, Brahana, and Johnston, 2000; Laubhan, 2007; Steele and McCalister, 1990). Protection of these systems is paramount as karst aquifers are important sources of drinking water; as much as one quarter of the world's population obtains its 
drinking water from karst aquifers (Ford and Williams, 2007).

Many karst systems are mantled by a layer known as regolith or epikarst, generally defined as the dissolutionally weathered, typically 3-15 $m$ thick, upper portion of the carbonate bedrock (Ford and Williams, 2007). The U.S. karst map (Veni and others, 2001) identifies more than $50 \%$ of U.S. karst as being buried, i.e, covered by the epikarst.

Epikarst hydrology is distinctly different from that in the underlying bedrock and could be conducive to significant microbial activity including denitrification, which is the most important $\mathrm{NO}_{3}{ }^{-}$attenuation process removing $\mathrm{NO}_{3}{ }^{-}$from watersheds in the form of gaseous nitrogen. For example, as porosity and permeability diminish with depth, the epikarst has a tendency to detain and delay recharge (Aquilina, Ladouche, and Dörfliger, 2006; Bakalowicz, 1995; Einsiedl, 2005), which translates into increase in residence time, an important factor facilitating denitrification (Green and others, 2009; Seitzinger and others, 2006). The decrease in permeability also induces lateral flow (Klimchouk, 2004) which acts to route the flow away from vertical shafts and conduits leading to the phreatic zone in the deeper bedrock. Studies have documented that the epikarst is a chemically reactive zone changing the chemistry of recharging water with respect to $\mathrm{Cl}-, \mathrm{Br}-$, oxygen-18 and deuterium (Aquilina and others, 2006) as well as attenuating organic dye and phosphate tracers (Sinreich and Flynn, 2011).

At the same time, epikarst discharge has been found to constitute as much as 55\% of the total discharge volume of springs or small catchments (Lee and Krothe, 2001). Therefore, the quality of waters discharging out of karst watersheds likely is dictated to a great degree by biogeochemical processes taking place in the epikarst, which emphasizes the importance of understanding of biogeochemical functioning of the epikarst.

While various aspects of epikarst hydrology have been well established, the understanding of its biogeochemical functioning, including the processes of nitrate attenuation, is lacking. A number of studies on this topic have characterized karst systems where the epikarst was present (Einsiedl, 2005; Lee and Krothe, 2001; Panno, Hackley, Hwang, and Kelly, 2001), but none focused solely on the epikarst itself.

The purpose of our investigation was to add to the knowledge of the biogeochemical functioning of the epikarst and, more specifically, to identify denitrification and its spatial and temporal variation as well as any controlling factors in an epikarst system with well-delineated hydrology. Study methods relied on a complex geochemical characterization involving measuring concentration and stable isotopes of all of the key reactants and products of the denitrification reaction, including nitrate, dissolved organic and inorganic carbon, and dissolved dinitrogen. The application of dissolved dinitrogen measurements to detect denitrification in an epikarst system is somewhat novel. While commonly applied to aquatic and marine systems, the technique rarely has been employed in unsaturated terrestrial systems due to challenges posed by high $\mathrm{N}_{2}$ background and its rapid exchange with air (Groffman and others, 2006), and there appears to be no study that has employed it specifically in the epikarst.

\section{Site Description}

The study site is located at the Savoy Experimental Watershed (SEW) near the town of Savoy in northwest Arkansas. The landscape of SEW is characterized by steep-sided valleys cut into a highly dissected plateau formed on impure, chert-rich limestone. Land use is dictated by the topography, with the steep side slopes and narrow ridge tops in hardwood forest and the broader ridge tops and valley bottoms in permanent pasture characteristic of the Illinois River Watershed. Geologically, the SEW represents the regolith-mantled karst setting of the Ozark Highlands, and is a geologic setting typical of approximately $15 \%$ of the eastern U.S., where karstified carbonate bedrock is overlain by a variable thickness of erosional residuum (regolith or epikarst) composed mainly of clay and rock fragments of silicic carbonate. The epikarst at the site is from 1 to $4 \mathrm{~m}$ thick. The soil at the top consists of up to $60 \%$ of rock 
fragments, which become more abundant and also progressively turn into more continuous and less weathered rock ledges with depth. A detailed pedologic characterization of the site can be found in Sauer and Logsdon (2002) and a structural description of the epikarst based on subsurface geophysics in Ernenwein and Kvamme (2004).

\section{METHODOLOGY}

Denitrification was studied in a section of the epikarst in Basin 1 of the SEW. Samples were collected at two stages of the hydrologic gradient of the epikarst section: an interceptor trench located on a sloping (15\%) ridge-top pasture and five epikarst springs (J1-J5) located on the side slope from 29 to $137 \mathrm{~m}$ downgradient from the trench (fig. 1). The trench is about $1.5 \mathrm{~m}$ deep, excavated down to relatively unweathered carbonate bedrock, and fitted with a French drain. The trench serves to intercept waters representative of epikarst throughflow. The springs are natural, terminal discharge points of the epikarst flowpaths and thus provide samples representing the final geochemical signature of waters leaving the epikarst. The springs were fitted with V-notch weirs for accurate discharge measurement. The hydrologic connections between the trench and each of the springs had previously been established by dye tracing (Laincz, 2007). Prior to sampling, chicken litter was applied at a rate of 5 tons per acre across the pasture area of about $80 \times 150 \mathrm{~m}$ upgradient from the trench in March 2011 to simulate common $\mathrm{NO}_{3-}$ loading practices in Arkansas and also to increase $\mathrm{NO}^{3-}$ signal.

Samples were collected following each of four consecutive storm events from May 2011 until July 2011 in conditions of increased saturation and flow. Water samples were collected from the trench and all of the springs for each storm event. Samples were collected into appropriate containers for each type of chemical and isotopic analysis, and filtered and preserved in accordance with guidelines from the analyzing lab. For anion $\left(\mathrm{NO}_{3-}, \mathrm{Cl}^{-}\right)$and

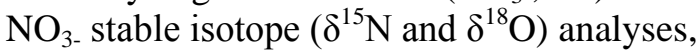
samples were collected without filtration or preservation. For DOC/DIC concentration and ${ }^{13} \mathrm{C}$ stable isotope analysis, samples were filtered on-site $(0.7 \mu \mathrm{m}$ Whatman GF/F filters in a Millipore 47-mm syringe filter assembly), and samples for DOC $-{ }^{13} \mathrm{C}$ isotopic analysis were acidified with $85 \% \mathrm{H}_{3} \mathrm{PO}_{4}$. For dissolved-gas analyses, samples were collected via a portable sampler (Masterflex E/S, Cole-Parmer, Vernon Hills, IL) directly from the point of emergence of water from the ground to minimize contact with air. The pump outflow tubing was inserted to the bottom of a sample vial, with $234 \mu \mathrm{l}$ of $50 \% \mathrm{ZnCl}_{2}$ preservative solution (1.2\% final conc., v/v) pre-dosed in each vial (18 ml Kimax

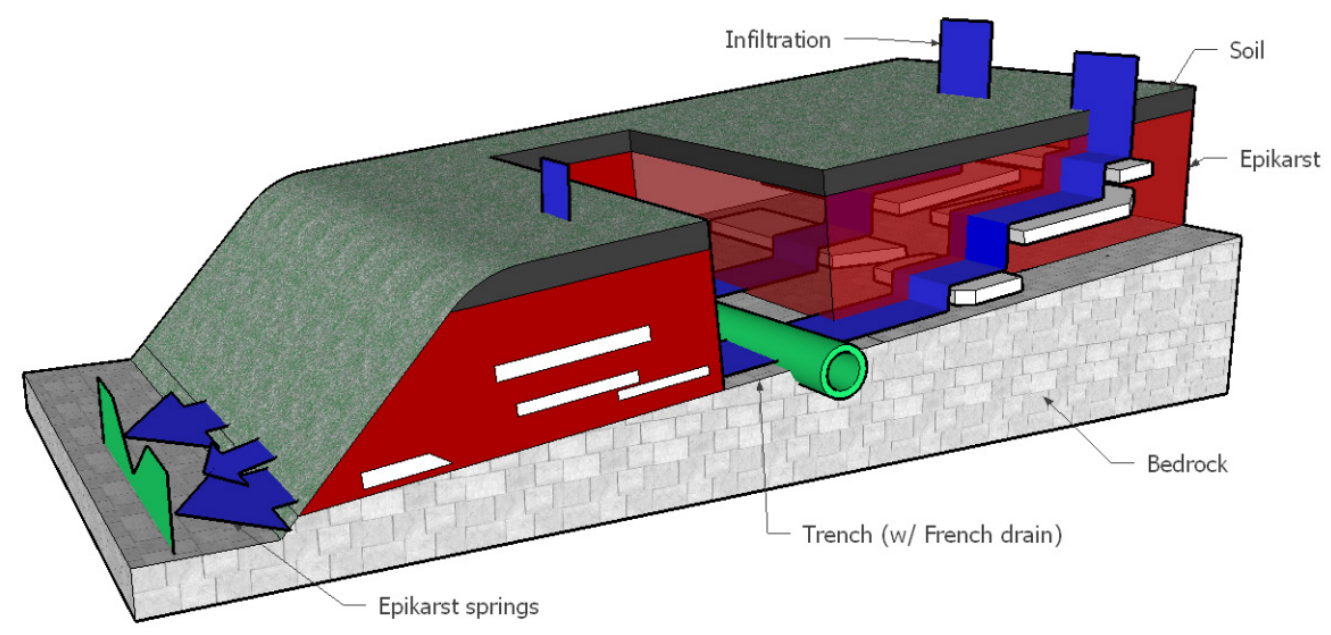

Figure 1. Conceptual model of the epikarst illustrating the lateral flow and sampling points along the flowpath. (Not to scale) 
test tube with a ground glass stopper), and water was pumped at a slow rate to prevent bubble formation before the vial was stoppered, sealed with Parafilm, and carefully checked to ascertain that no air bubbles were present. Samples were placed on ice and transported into laboratory, where they were stored in the dark at $4^{\circ} \mathrm{C}$ until analysis. During sample collection, several field and environmental parameters were measured including $\mathrm{pH}$, electrical conductivity, temperature, dissolved oxygen (DO), and barometric pressure.

\section{Chemical Analyses}

Chemical analysis of samples for major anions and cations was conducted at the Arkansas Department of Environmental Quality Water Quality Lab using ion chromatography (U.S. Environmental Protection Agency (EPA) method 300.0) and inductively coupled plasmaatomic emission spectrometry (EPA method 200.7), respectively. Stable isotopes of $\mathrm{NO}^{3-}$ $\left(\delta^{15} \mathrm{~N}\right.$ and $\left.\delta^{18} \mathrm{O}\right)$ were analyzed at the University of Arkansas Stable Isotope Lab using the denitrifier method (Casciotti, Sigman, Hastings, Bohlke, and Hilkert, 2002; Sigman and others, 2001) involving the use of genetically modified denitrifier to quantitatively convert sample $\mathrm{NO}_{3}{ }^{-}$ to $\mathrm{N}_{2} \mathrm{O}$, with adaptations described in Winston (2006). The analysis was performed using a GasBench II system with a $\mathrm{CO}_{2}$ trap made of stainless steel and organics and a water trap consisting of isopropanol-dry ice slush, connected to a continuous flow isotope ratio mass spectrometer (XP, ThermoFinnigan, Bremen, Germany). The method precision for $\delta^{15} \mathrm{~N}$ and $\delta^{18} \mathrm{O}$ was \pm 0.46 and $\pm 0.49 \%$, respectively. The results are expressed in the text below in $\delta$ notation defined as $\delta \mathrm{X}(\%)=$ $\left(\mathrm{R}_{\mathrm{s}} / \mathrm{R}_{\mathrm{st}}-1\right) * 1000$, where $\mathrm{X}$ is ${ }^{15} \mathrm{~N},{ }^{18} \mathrm{O}$, or ${ }^{13} \mathrm{C}$, and $\mathrm{R}$ is the ${ }^{15} \mathrm{~N} /{ }^{14} \mathrm{~N},{ }^{18} \mathrm{O} /{ }^{16} \mathrm{O},{ }^{13} \mathrm{C} /{ }^{12} \mathrm{C}$ ratios of the sample (s) and reference standard (st), respectively. The reference standards were Air for $\delta^{15} \mathrm{~N}$, Vienna Standard Mean Ocean Water (VSMOW) for $\delta^{18} \mathrm{O}$, and Vienna Pee Dee belemnite (VPDB) for ${ }^{13} \mathrm{C}$. DOC and DIC concentration and stable isotope $\left({ }^{13} \mathrm{C}\right)$ composition were analyzed at the Colorado Plateau Stable Isotope Lab, Flagstaff, AZ, using an O.I. Analytical Model 1010 TOC analyzer (OI Analytical, College Station, TX) interfaced to a Finnigan Delta+ XL isotope ratio mass spectrometer (Finnigan-MAT, San Jose, CA) (St-Jean, 2003). The DIC and DOC measurements had an error margin of \pm 0.03 and $\pm 0.13 \%$, respectively. Dissolved $\mathrm{O}_{2}$ and $\mathrm{N}_{2}$ analyses were performed in the Scott Biogeochemistry Lab at the University of Arkansas Department of Crop, Soil and Environmental Sciences using a membrane inlet mass spectrometry (MIMS) setup consisting of a Pfeiffer Prisma mass spectrometer and a Bay Instruments DGA membrane inlet S-25-75. The MIMS setup and analysis are described in detail in Kana and others (1994) and Grantz and others (2012), respectively. The precision of the MIMS analysis was $\pm 0.3 \%$.

\section{RESULTS}

\section{Nitrate Concentration and $\delta^{15} \mathrm{~N}$ and $\delta^{18} \mathrm{O}$}

Nitrate concentrations ranged from 1.5 to $7.6 \mathrm{mg} / \mathrm{L}$, with an average of approximately 3 $\mathrm{mg} / \mathrm{L}$. These concentrations are similar to those reported for the watershed by other authors (Sauer and others, 2008; Winston, 2006). The $\mathrm{NO}_{3}{ }^{-}$concentration did not seem to have been significantly affected by the application of chicken litter two months prior to the test. The average $\mathrm{NO}_{3}{ }^{-}$concentrations of the trench and spring water samples were 4.7 and $2.6 \mathrm{mg} / \mathrm{L}$, respectively. The $\mathrm{NO}_{3}{ }^{-}-\delta^{18} \mathrm{O}$ values ranged between 1.3 and $4.6 \%$. The trench average was higher than the springs average (5.2 and 3.7\%o, respectively). The $\mathrm{NO}_{3}{ }^{-}-\delta^{15} \mathrm{~N}$ values varied between 2.5 and $5.8 \%$. The trench samples averaged approximately 2\%o while water from the springs averaged 3.6\%o. The measured $\mathrm{NO}_{3-}-$ $\delta^{15} \mathrm{~N}$ and $-\delta^{18} \mathrm{O}$ values are consistent with $\mathrm{NO}_{3}{ }^{-}$ originating from soil organic matter and animal waste (i.e., manure, chicken litter) (Kendall and McDonnell, 1998). The indicated origin is accurate as soil and animal waste were in fact the primary potential sources of $\mathrm{NO}_{3}{ }^{-}$at the site.

\section{DIC, DOC Concentration, and $\delta^{13} \mathrm{C}$}

DIC varied from 7.2 to $35.5 \mathrm{mg} / \mathrm{L}-\mathrm{C}$, with an average of $25.5 \mathrm{mg} / \mathrm{L}-\mathrm{C}$. The average DIC concentrations of the trench and spring samples were $28.6 \mathrm{mg} / \mathrm{L}-\mathrm{C}$ and $10.1 \mathrm{mg} / \mathrm{L}-\mathrm{C}$, respectively. Isotope analyses showed the DIC $\delta^{13} \mathrm{C}$ values ranging between -13 and $-21 \%$. The 
springs averaged at approximately $-15 \%$ o while the trench average was lower $(-19 \%)$. DOC concentration varied between 0.3 and $4.8 \mathrm{mg} / \mathrm{L}$ C. DOC concentration in the springs averaged $0.8 \mathrm{mg} / \mathrm{L}-\mathrm{C}$, which is typical for groundwater, while the trench average was higher, at 3.9 $\mathrm{mg} / \mathrm{L}-\mathrm{C}$, possibly as a result of being situated closer to the organics-rich soil zone than the springs. DOC $\delta^{13} \mathrm{C}$ values were within a relatively narrow range of about -25 to $-27 \%$. This is an expected range that accurately pinpoints the origin of this DOC in the local vegetation dominated by $\mathrm{C}-3$ plants.

\section{Dissolved $\mathrm{N}_{2}$ and $\mathrm{O}_{2}$}

Dissolved $\mathrm{N}_{2}$ concentration ranged from 15.1 to $17.2 \mathrm{mg} / \mathrm{L}$. The concentration data varied in both time and space. Spatially, on average, the highest concentration was in $\mathrm{J} 2(103 \mathrm{mg} / \mathrm{L})$ while the lowest was in J5 samples (100.8 mg/L). Temporally, samples collected on April 28 had the highest average concentration (104.2 $\mathrm{mg} / \mathrm{L}$ ) while the lowest average concentration was found in the only sample of April 15 (99.4 $\mathrm{mg} / \mathrm{L}$ ). $\mathrm{N}_{2}$ saturation levels calculated from $\mathrm{N}_{2}$ :Ar ratios and Ar concentrations ranged from 99.4 to $105.6 \%$, with an average of $102.2 \%$. All but three samples were supersaturated with respect to $\mathrm{N}_{2}$, i.e., their $\mathrm{N}_{2}$ content exceeded the equilibrium-with-air concentration or $100 \%$ saturation. DO concentration ranged from 4.9 to $8.2 \mathrm{mg} / \mathrm{L}$ and averaged $6.5 \mathrm{mg} / \mathrm{L}$. On average, the highest DO concentration was in the trench (7.9 mg/L), the lowest in $\mathrm{J} 2(5.1 \mathrm{mg} / \mathrm{L})$.

Temporally, the variation in DO was small, with the highest value at $7.1 \mathrm{mg} / \mathrm{L}$ on 4/15 (only one sample from J3) and the lowest average at 6.2 $\mathrm{mg} / \mathrm{L}$ on $4 / 28$. Calculated $\mathrm{O}_{2}$ saturation ranged between 46.9 and $90.5 \%$ and averaged $65.9 \%$. The trends of temporal and spatial averages were similar to those for DO concentration.

\section{DISCUSSION}

\section{Nitrate Concentration and $\delta^{15} \mathrm{~N}$ and $\delta^{18} \mathrm{O}$}

The $\mathrm{NO}_{3}{ }^{-}$concentration data show a pattern of decreasing concentration between the trench and the springs. The concentration of the former was on average two times higher than of the latter. The processes that in subsurface situations can cause decreases in $\mathrm{NO}_{3}{ }^{-}$concentration are dilution and denitrification (Clark and Fritz, 1997). Dilution did not appear to be the cause since chloride concentration between these two points of the flowpath did not decrease. Consequently, the likely process responsible for the $\mathrm{NO}_{3}{ }^{-}$depletion was denitrification.

Denitrification causes an isotopic enrichment in both ${ }^{15} \mathrm{~N}$ and ${ }^{18} \mathrm{O}$ of the remnant $\mathrm{NO3}^{-}$, with the ${ }^{15} \mathrm{~N}$ enrichment approximately twice that of ${ }^{18} \mathrm{O}$ (Bottcher, Strebel, Voerkelius, and Schmidt, 1990; Mariotti, Landreau, and Simon, 1988). This phenomenon shows on a $\delta^{15} \mathrm{~N}$ vs. $\delta^{18} \mathrm{O}$ plot as a line with a positive slope of 0.5 . While all of the samples do not produce such trend, the trench samples $\delta^{15} \mathrm{~N}$ and $\delta^{18} \mathrm{O}$ exhibit a strongly positive correlation with a slope of 0.6 (fig. 2). This is an indication of denitrification in the upper compartment of the epikarst drained by the trench. Further down the flowpath, the spring samples do not show any definite $\delta^{15} \mathrm{~N}-\delta^{18} \mathrm{O}$ relation. Denitrification might be occurring on the flow path to the springs as well, but the remnant $\mathrm{NO}_{3}{ }^{-}$may mix with $\mathrm{NO}_{3}{ }^{-}$ from extraneous sources (e.g. decomposition of organic matter) concealing the isotopic signature of denitrification.

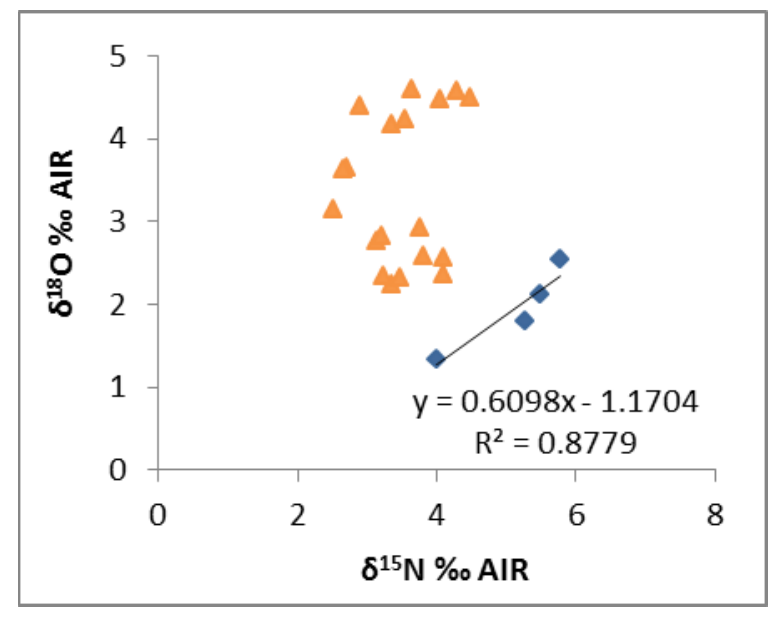

Figure 2. Isotopic composition of nitrate in trench samples (squares) and spring samples (triangles).

\section{DIC Concentration and $\delta^{13} \mathrm{C}$}

The denitrification reaction also is known to increase DIC concentration (Aravena and Robertson, 1998) as well as to impart ${ }^{13} \mathrm{C}$ depletion to the DIC through the addition of ${ }^{13} \mathrm{C}$ depleted organic carbon participating in the reaction (Fritz, Cherry, Weyer, and Sklash, 
1976). The spring samples indeed had significantly higher DIC compared to the trench samples, with the average concentration in the springs about 3 times that in the trench. This DIC, however, was not depleted in ${ }^{13} \mathrm{C}$ relative to the trench values. A likely reason is addition of DIC via carbonate dissolution along the flowpath. If the only DIC source was denitrification, DIC in the samples would have a $\delta^{13} \mathrm{C}$ in the range of its source organic matter (Aravena and Robertson, 1998). In this case, the $\delta^{13} \mathrm{C}$ of dissolved organic matter of all samples ranged $25-27 \%$. However, if the aquifer is a carbonate aquifer, dissolution of carbonate minerals $\left(\delta^{13} \mathrm{C} \sim 0 \%\right.$ o) will buffer the input of the depleted ${ }^{13} \mathrm{C}$ generated by denitrification.

Mixing equal amounts of organic $\left(\delta^{13} \mathrm{C}=-26 \%\right)$ and inorganic $\left(\delta^{13} \mathrm{C}=0 \%\right)$ carbon would generate DIC with a $\delta^{13} \mathrm{C}$ value of $-13 \%$. A calculation using a binary mixing equation shows that DIC with the same $\delta^{13} \mathrm{C}$ value as the average for the springs (-15\%) would be produced by mixing of about $42 \%$ of inorganic and $58 \%$ of organic carbon. Thus, denitrification may have been occurring along the trench-tospring flowpaths and is responsible for the $\mathrm{NO}^{-}$ depletion observed at the springs, but the expected DIC $\delta{ }^{13} \mathrm{C}$ response was masked by DIC from calcite dissolution.

Applying the same approach as with $\mathrm{NO}_{3}{ }^{-}$ isotopes and separately analyzing for trends in the spring samples and the trench samples, a positive relation was noted between DIC and $\delta^{13} \mathrm{C}$ in the trench samples, indicating denitrification occurring in the upper epikarst compartment drained by the trench (fig. 3). This is consistent with the $\mathrm{NO}^{-} \delta^{15} \mathrm{~N}$ and $\delta^{18} \mathrm{O}$ data, which also indicated denitrification in the trench samples. The spring samples, however, exhibited a weakly positive trend for DIC vs. $\delta^{13} \mathrm{C}$, which does not support an interpretation of denitrification; however, as shown by the above mixing calculation, mixing in the epikarst may have occurred and could be masking the effect of denitrification on the DIC and $\delta^{13} \mathrm{C}$ composition of the samples.

\section{Dissolved $\mathrm{N}_{2}$ and $\mathrm{O}_{2}$}

The most significant observation that can be made from the data is that 18 out of 21 samples were supersaturated with respect to $\mathrm{N}_{2}$. This supersaturation is most probably the footprint of denitrification because virtually no other process could feasibly occur in this system that would cause dissolved $\mathrm{N}_{2}$ to increase beyond saturation levels. The only other possible process would be the incorporation of excess air, i.e., the dissolution of air bubbles entrapped in capillarysized pore spaces by downward migrating waters. This mechanism, however, is only feasible at sufficient depth and hydrostatic pressure below the water table, with about $10 \mathrm{~m}$ depth required for complete dissolution of the air bubbles (Heaton and Vogel, 1981). The thin (generally $<2 \mathrm{~m}$ ) and transiently saturated epikarst does not offer conditions for the occurrence of this process. Denitrification as the cause of $\mathrm{N}_{2}$ supersaturation is corroborated by multiple lines of evidence already presented $\mathrm{NO}_{3}{ }^{-}$and DIC concentrations as well as the corresponding isotopic data. Hence, denitrification is the most plausible cause of $\mathrm{N}_{2}$ supersaturation.

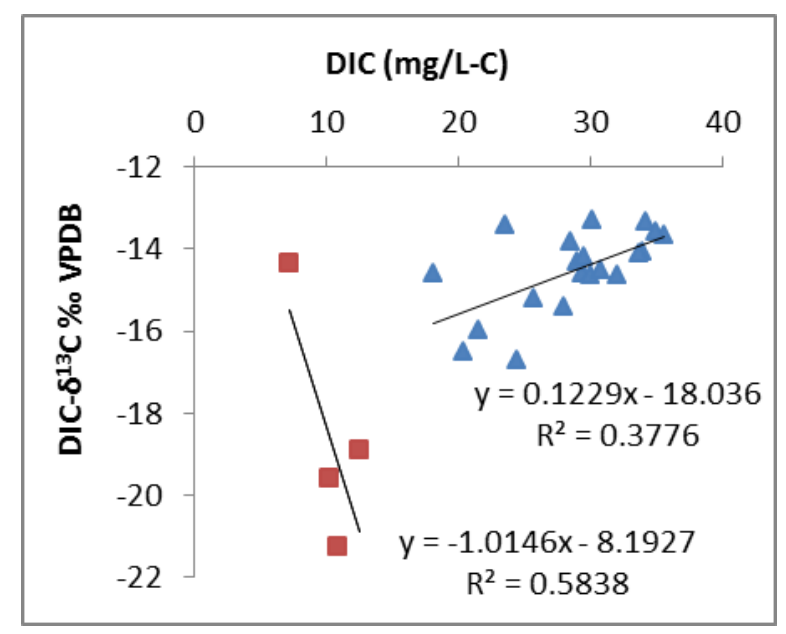

Figure 3. Relationship between DIC concentration and $\delta^{13} \mathrm{C}$ in trench samples (squares) and spring samples (triangles).

We have not found any other denitrification studies that determined $\mathrm{N}_{2}$ supersaturation in the epikarst or in other groundwater systems, which precluded comparison of the data with similar studies. However, a few studies, which determined $\mathrm{N}_{2}$ supersaturation linked to denitrification in deep sea waters, report values in the range between $101 \%$ and $108 \%$

(Quinones-Rivera and others, 2007; Rönner and 
Sörensson, 1985). This range is similar to the values obtained in our study.

Most denitrifiers are facultative anaerobes and, consequently, denitrification requires anoxic or very low oxygen conditions generally below $0.2 \mathrm{mg} / \mathrm{L}$ (Tiedje, 1988). The measured $\mathrm{O}_{2}$ concentration, however, was in the range of 4.7-8.2 $\mathrm{mg} / \mathrm{L}$ and therefore, any denitrification activity in the epikarst would have to be restricted to anoxic mircroenvironments such as those described by Sexstone and others (1985) or Koba and others (1997). Such microsites could exist in the studied epikarst, indeed; pockets of grayish colors indicative of reducing conditions were observed in abundance throughout the epikarst profile during excavation works at the site.

Concentration of $\mathrm{O}_{2}$ within these microsites would probably be affected by $\mathrm{O}_{2}$ concentration in the surrounding matrix; the lower the latter, the lower the former. As a result, granted that all other requirements for denitrification are met, one could expect to see that the less $\mathrm{O}_{2}$ is in the system as a whole, the more denitrification will occur in these microsites. This phenomenon would then manifest itself as a negative correlation between the measured $\mathrm{N}_{2}$ and $\mathrm{O}_{2}$ saturation levels. While such correlation is found to be only negligible for the entire dataset, correlation is relatively strong when the highest $\mathrm{O}_{2}$ saturation sites - the trench and J1 site - are excluded from the analysis (fig. 4). The exclusion seems justified since the relatively high $\mathrm{O}_{2}$ content of waters from these two sites could well be due to the distinct physical hydrologic character of these flowpaths as opposed to being a reflection of some intrinsic biogeochemical process affecting the $\mathrm{O}_{2}$ content in the epikarst (i.e. aerobic or anaerobic respiration consuming $\mathrm{O}_{2}$ along the other flowpaths). This is especially true for the trench waters which could be oxygenated in the final, pipe segment of the installed collector (French drain) of this flowpath. The J1 flowpath, as suggested by discharge and specific conductance (this study data) as well as DOC bioavailability (Winston, 2006), is dominated by focused flow, a more turbulent type of flow characterized by increased potential for oxygenation. Thus, a combined analysis of $\mathrm{N}_{2}$ and $\mathrm{O}_{2}$ data indicates denitrification occurring along the J2-J5 flowpaths of the epikarst. Dissolved $\mathrm{O}_{2}$, or lack thereof, appears to play a role in enabling this denitrification.

The effect of $\mathrm{O}_{2}$ saturation on denitrification suggested by the data invites the question as to exactly what mechanism could enable the further drawdown of $\mathrm{O}_{2}$ concentration, creating anaerobic conditions within the microsites. While, in general, dissolved $\mathrm{O}_{2}$ is consumed by aerobic or anaerobic microbial activity and geochemical reactions, the key mechanism enabling the development of anoxic conditions in the microsites could be the blocking of access of $\mathrm{O}_{2}$ by waterlogging. The phenomenon of waterlogging causing an increase in denitrification and consequently loss of soil nitrogen by restricting oxygen diffusion to the soil is widely known among agronomists and soil scientists. Under certain conditions, even a small percentage increase in soil saturation can initiate denitrification by sealing off a sufficient soil volume from diffusion of atmospheric $\mathrm{O}_{2}$ (Craswell, 1978). Similarly, according to Sylvia and others (1999), rates of denitrification are

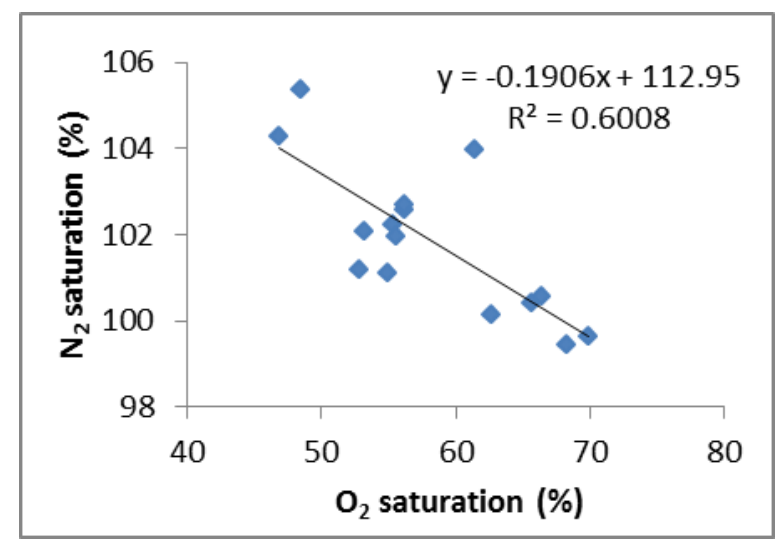

Figure 4. Relationship between dissolved oxygen and nitrogen saturation in J2-J5 spring samples (samples from $\mathrm{J} 1$ and trench are excluded).

generally greatest in wet soils where more than $80 \%$ of pore space is saturated and respiratory activity is reasonably high. The data in this study provide some evidence for the occurrence of this mechanism in the epikarst. Assuming the average discharge for a sampling event to be a measure of epikarst saturation, the highest epikarst saturation event (4/28) had the lowest average $\mathrm{O}_{2}$ saturation (and the highest average 
$\mathrm{N}_{2}$ saturation), the lowest epikarst saturation event (4/15) had the highest $\mathrm{O}_{2}$ saturation (and the lowest $\mathrm{N}_{2}$ saturation), and the two intermediate epikarst saturation events had proportionally inverse intermediate $\mathrm{O}_{2}$ saturation (and intermediate $\mathrm{N}_{2}$ saturation) (fig. 5). When the analysis is conducted for the sites individually instead of averaging the sites for each event, the trend of increasing discharge with decreasing $\mathrm{O}_{2}$ saturation is present for all sites except for the trench. This inconsistency again could be caused by aeration effects of the collector elevating the $\mathrm{O}_{2}$ content of trench waters, particularly at higher discharge rates. The evidence overall thus indicates that physical hydrology of the epikarst can control geochemistry, specifically, $\mathrm{O}_{2}$ concentration and subsequently denitrification. The analysis, however, relies on only four events and uses discharge to assess water saturation. The trend therefore should be confirmed with an analysis involving more measurements and perhaps some more direct method of measuring water saturation (e.g., the electrical resistivity method).

\section{DOC}

One of the reactants of denitrification is organic carbon, which the microbes use as an electron donor. Denitrifying activity has been found to be related to organic carbon contents in a wide range of environments, including sediments (Van Kessel, 1978), soils (Bremner and Shaw, 1958; Burford and Bremner, 1975), riparian zones (Vidon and Hill, 2005), shallow aquifers (Starr and Gillham, 1993) as well as oxic surface waters and porewaters (Sobczak and Findlay, 2002). The data from this study suggest this to also be the case in the epikarst; for the spring samples, $\mathrm{N}_{2}$ saturation, which can be taken as a proxy measure of denitrification, is positively correlated with DOC concentration (fig. 6). This correlation does not hold when the trench samples are included in the analysis due to their abnormally high DOC levels, on average about 5 times higher than those in the springs. These are suspected to be caused by contamination of carbon compounds leaching from surface-derived organic detritus accumulated in the French drain gravel pack and pipe. The trench samples, therefore, were excluded. In addition, the utilization of DOC by denitrifiers also depends on quality or bioavailability of this DOC. While this parameter was not assessed, the positive relation between DOC and $\mathrm{N}_{2}$ saturation suggests that this DOC was sufficiently labile for denitrifiers.

The relation thus indicates that carbon availability has a limiting effect on denitrification in the epikarst, and two reasons may explain why this perhaps should be the case in the epikarst even more than in other environments: Firstly, in general, in environments that are not completely anaerobic such as the epikarst, denitrifiers have to compete for carbon with obligately aerobic heterotrophs, which make up the bulk of the microbial biomass in these environments (Sylvia and others, 1999). Secondly, organic carbon in the system is already a limited resource due to the
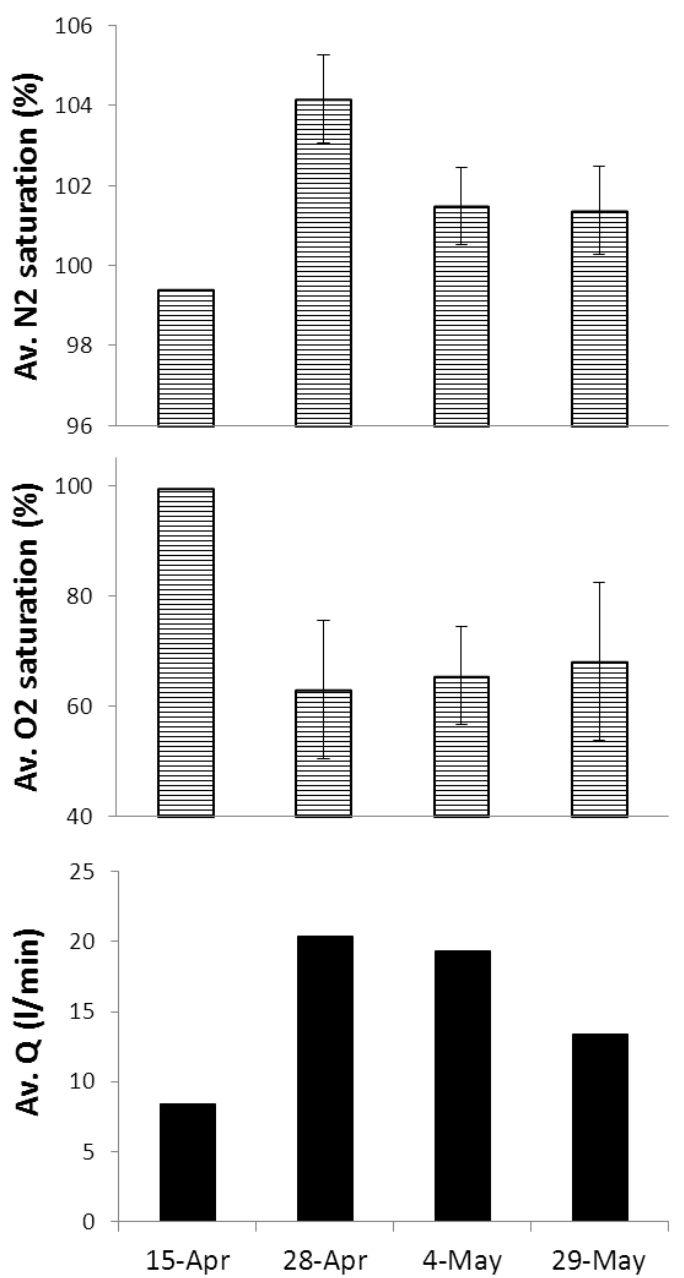

Figure 5. Average discharge (Q), $\mathrm{O}_{2}$ saturation, and $\mathrm{N}_{2}$ saturation for four sampling events (error bars represent mean $+/-1$ SD). 
fact that karst groundwater systems do not have significant autotrophic sources of organic carbon (Susan Ziegler, personal comm.).

The correlation also shows data points clustered according to event date, with the higher discharge events having higher $\mathrm{N}_{2}$ saturation and DOC concentration (fig. 6). This indicates that hydrology (epikarst saturation) not only impacts $\mathrm{O}_{2}$ concentrations and subsequently denitrification in the epikarst as noted before, but epikarst saturation also seems to exert control on denitrification by controlling DOC availability. Higher discharge events likely mobilize and deliver more DOC than lower discharge events. The greater supply of DOC then likely translates into a greater denitrification potential during storm events. This dynamic makes the epikarst different from surface systems where storm-flow events are typically thought of as events where more refractory carbon is delivered (Susan Ziegler, personal comm.). The lack of significant autotrophic sources of carbon means that the epikarst system depends upon the pulse of carbon from storm events.

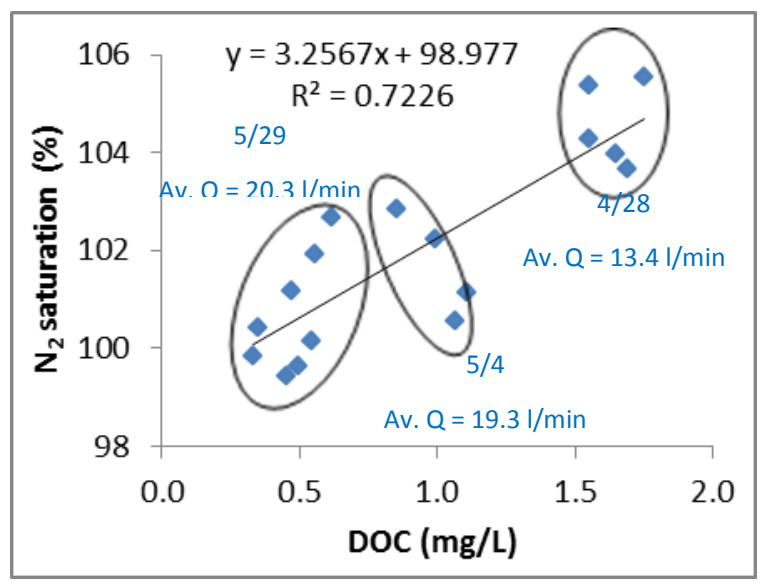

Figure 6. Relationship between DOC concentration and N2 saturation of spring samples (trench samples are excluded). Circles enclose datapoint clusters which correspond with sampling dates with varying hydrologic conditions (saturation) as indicated by average discharge (avg. Q).

\section{CONCLUSIONS}

The occurrence of denitrification along the flowpaths between the trench and the epikarst springs was indicated by the general trend of $\mathrm{NO}_{3}^{-}$depletion, which in the absence of dilution could only be caused by denitrification.
Additional geochemical indicators, including relations between nitrate $\delta^{15} \mathrm{~N}$ and $\delta^{18} \mathrm{O}$ as well as DIC concentration and DIC $\delta^{13} \mathrm{C}$, did not corroborate this evidence, although it is possible that the positive signature of denitrification had been masked - in the case of $\mathrm{NO}^{-}$isotopic composition by mixing in of extraneous $\mathrm{NO}^{-}$ and in the case of DIC $\delta^{13} \mathrm{C}$ by dissolution of calcite.

Denitrification was also detected in the epikarst upgradient from the trench. The evidence includes the trend of simultaneous enrichment in nitrate ${ }^{15} \mathrm{~N}$ and ${ }^{18} \mathrm{O}$ and another trend of increasing depletion in ${ }^{13} \mathrm{C}$ of DIC as DIC concentration in the trench samples increased. The trench waters also had higher concentration of DOC relative to the epikarst springs, being closer to the soil zone DOC source, which would give the former a greater potential for denitrification.

The most significant finding of this study is the dissolved $\mathrm{N}_{2}$ supersaturation detected in all except for three samples, strongly signaling denitrification in the epikarst. Negative correlation between $\mathrm{N}_{2}$ and $\mathrm{O}_{2}$ saturation suggested that the magnitude of denitrification is controlled by oxygenation levels of the epikarst waters. Oxygen concentration, in turn, seemed to have been affected by the wetness or saturation level of the epikarst as suggested by negative correlation between discharge and $\mathrm{O}_{2}$ saturation. Thus, as is the case in soils, hydrology (waterlogging) appears to be an important control on denitrification in the epikarst.

Further, $\mathrm{N}_{2}$ saturation was positively correlated with DOC concentration indicating a limiting role of carbon in denitrification in this system. Such a situation would be expected given the lack of autotrophic sources in karst and the dominant presence of obligately aerobic heterotrophs which compete with denitrifiers for carbon. As with the $\mathrm{O}_{2}$ content, hydrologic conditions also appear to affect DOC: higher discharge events tended to have higher DOC concentrations. The greater storm pulses likely are able to mobilize and deliver more $\mathrm{C}$ which then drives denitrification activity.

The suite of geochemical parameters measured for this study indicates denitrification 
occurring in this epikarst system. While the experimental approach did not allow for quantitative evaluation of denitrification or its controlling variables, it succeeded in identifying their occurrence, which is a valuable contribution to understanding the biogeochemical functioning of the epikarst. These findings also reaffirm the concept that within karst systems characterized by limited soil development and lack of bioremediation capacity, the epikarst is a potentially important zone of attenuation of leaching nitrate. The findings serve as a foundation for future, more quantitative investigations of these epikarst phenomena and of their response to specific nutrient management practices so that they may be optimized to reflect the ecological limitations of vulnerable karst landscapes.

\section{ACKNOWLEDGMENTS}

The authors would like to thank Dr. Van Brahana of the University of Arkansas and Mr. Tim Kresse of the U.S. Geological Survey for their helpful reviews. Dr. Thad Scott of the University of Arkansas shared his expertise and equipment for dissolved gas analysis. Mr. Roger Miller of the Arkansas Department of Environmental Quality assisted with water chemistry analysis. Finally, this research was made possible in large part by funding from the U.S. Department of Agriculture, National Resources Conservation Service - National Water Management Center and the Arkansas Water Resources Center.

\section{REFERENCES}

Adamski, J.C., 1997, Nutrients and pesticides in ground water of the Ozark Plateaus in Arkansas, Kansas, Missouri, and Oklahoma: U.S. Geological Survey Water-Resources Investigations Report 96-4313, 28 p.

Aquilina, L., Ladouche, B., and Dörfliger, N., 2006, Water storage and transfer in the epikarst of karstic systems during high flow periods: Journal of Hydrology, v. 327, no. 3-4, p. 472-485.

Aravena, R., and Robertson, W.D., 1998, Use of multiple isotope tracers to evaluate denitrification in ground water: Study of nitrate from a largeflux septic system plume: Ground Water, v. 36, no. 6, p. 975-982.
Bakalowicz, M., 1995, La zone d’infiltration des aquifères karstiques. Méthodes d'étude: Structure et fonctionnement: Hydrogéologie, v. 4, p. 3-21.

Bottcher, J., Strebel, O., Voerkelius, S., and Schmidt, H.L., 1990, Using isotope fractionation of nitratenitrogen and nitrate-oxygen for evaluation of microbial denitrification in a sandy aquifer: Journal of Hydrology, v. 114, no. 3-4, p. 413-424.

Boyer, D.G., and Pasquarell, G.C., 1996, Agricultural land use effects on nitrate concentrations in a mature karst aquifer: Journal of the American Water Resources Association, v. 32, no. 3, p. 565573 .

Bremner, J., and Shaw, K., 1958, Denitrification in soil. II. Factors affecting denitrification: The Journal of Agricultural Science, v. 51, no. 01, p. 40-52.

Burford, J., and Bremner, J., 1975, Relationships between the denitrification capacities of soils and total, water-soluble and readily decomposable soil organic matter: Soil Biology and Biochemistry, v. 7, no. 6, p. 389-394.

Casciotti, K.L., Sigman, D.M., Hastings, G.M., Bohlke, J.K., and Hilkert, A., 2002, Measurement of the oxygen isotopic composition of nitrate in seawater and freshwater using the denitrifier method: Analytical Chemistry, v. 74, no. 19, p. 4905-4912.

Clark, I.D., and Fritz, P., 1997, Environmental isotopes in hydrogeology: Boca Raton, Florida, CRC Press LLC, 328 p.

Craswell, E., 1978, Some factors influencing denitrification and nitrogen immobilization in a clay soil: Soil Biology and Biochemistry, v. 10, no. 3, p. 241-245.

Davis, R.K., Brahana, J.V., and Johnston, J.S., 2000, Groundwater in northwest Arkansas: Minimizing nutrient contamination from non-point sources in karst terrane: Arkansas Water Resources Center MSC-288, 69 p.

Einsiedl, F., 2005, Flow system dynamics and water storage of a fissured-porous karst aquifer characterized by artificial and environmental tracers: Journal of Hydrology, v. 312, no. 1, p. 312-321.

Ernenwein, E.G., and Kvamme, K.L., 2004, Geophysical investigations for subsurface fracture detection in the Savoy Experimental Watershed, Arkansas: Unpublished report, Department of Biological and Agricultural Engineering, University of Arkansas, 24 p. 
Ford, D.C., and Williams, P.W., 2007, Karst hydrogeology and geomorphology: Chichester, England, John Wiley \& Sons, 576 p.

Fritz, P., Cherry, J.A., Weyer, K.V., and Sklash, M.G., 1976, Storm runoff analysis using environmental isotopes and major ions, in Interpretation of environmental isotopes and hydrochemical data in groundwater hydrology. Panel Proceedings Series - International Atomic Energy Agency 108: Vienna, IAEA, p. 111-130.

Goolsby, D.A., and Battaglin, W.A., 2001, Longterm changes in concentrations and flux of nitrogen in the Mississippi River Basin, USA: Hydrological Processes, v. 15, no. 7, p. 12091226.

Green, M.B., Wollheim, W.M., Basu, N.B., Gettel, G., Rao, P.S., Morse, N., and Stewart, R., 2009, Effective denitrification scales predictably with water residence time across diverse systems: Nature Proceedings, accessed June 15, 2013, http://precedings.nature.com/documents/3520/ver sion $/ 1 /$ html.

Groffman, P.M., Alatabet, M.A., Bohlke, J.K., Butterbach-Bahl, K., David, M.B., Firestone, M.K., Giblin, A.E., Kana, T.M., Nielsen, L.P., and Voytek, M.A., 2006, Methods For measuring denitrification: Diverse approaches to a difficult problem: Ecological Applications, v. 16, no. 6, p. 2091-2122.

Heaton, T.H.E., and Vogel, J.C., 1981, "Excess air" in groundwater: Journal of Hydrology, v. 50, p. 201-216.

Kana, T.M., Darkangelo, C., Hunt, M.D., Oldham, J.B., Bennett, G.E., and Cornwell, J.C., 1994, Membrane inlet mass spectrometer for rapid highprecision determination of N2, O2, and Ar in environmental water samples: Analytical Chemistry, v. 66, no. 23, p. 4166-4170.

Kendall, C., and McDonnell, J.J., 1998, Isotope tracers in catchment hydrology: Amsterdam, Elsevier Science B.V., 839 p.

Klimchouk, A., 2004, Towards defining, delimiting and classifying epikarst: Its origin, processes and variants of geomorphic evolution: Speleogenesis and Evolution of Karst Aquifers, v. 2, no. 1, p. 113.

Koba, K., Tokuchi, N., Wada, E., Nakajima, T., and Iwatsubo, G., 1997, Intermittent denitrification: The application of a $15 \mathrm{~N}$ natural abundance method to a forested ecosystem: Geochimica et Cosmochimica Acta, v. 61, no. 23, p. 5043-5050.
Laubhan, A.C., 2007, A hydrogeologic and waterquality evaluation of the Springfield aquifer in the vicinity of north-central Washington County, Arkansas: Fayetteville, University of Arkansas, M.S. Thesis, 364 p.

Lee, E.S., and Krothe, N.C., 2001, A four-component mixing model for water in a karst terrain in southcentral Indiana, USA: Using solute concentration and stable isotopes as tracers: Chemical Geology, v. 179 , no. 1 , p. $129-143$.

Mariotti, A., Landreau, A., and Simon, B., 1988, N15 isotope biogeochemistry and natural denitrificatiion process in groundwater: Application to the chalk aquifer in northern France: Geochimica et Cosmochimica Acta, v. 52, p. 1869-1878.

Panno, S.V., Hackley, K.C., Hwang, H.H., and Kelly, W.R., 2001, Determination of the sources of nitrate contamination in karst springs using isotopic and chemical indicators: Chemical Geology, v. 179, no. 1-4, p. 113-128.

Power, J., and Schepers, J., 1989, Nitrate contamination of groundwater in North America: Agriculture, Ecosystems \& Environment, v. 26, no. 3, p. 165-187.

Quinones-Rivera, Z.J., Wissel, B., Justic, D., and Fry, B., 2007, Partitioning oxygen sources and sinks in a stratified, eutrophic coastal ecosystem using stable oxygen isotopes: Marine Ecology Progress Series, v. 342, p. 69-83.

Rabalais, N.N., Turner, R.E., Justic, D., Dortch, Q., Wiseman, W.J., and Sen Gupta, B.K., 1996, Nutrient changes in the Mississippi River and system responses on the adjacent continental shelf: Estuaries and Coasts, v. 19, no. 2, p. 386407.

Rönner, U., and Sörensson, F., 1985, Denitrification rates in the low-oxygen waters of the stratified Baltic proper: Applied and Environmental Microbiology, v. 50, no. 4, p. 801-806.

Sauer, T.J., Alexander, R.B., Brahana, J.V., and Smith, R.A., 2001, The importance and role of watersheds in the transport of nitrogen: in Follett, R.F. and Hatfield, J.L., eds., Nitrogen in the environment: Sources, problems, and management: Elsevier, p. 147-181.

Sauer, T.J., and Logsdon, S.D., 2002, Hydraulic and physical properties of stony soils in a small watershed: Soil Science Society of America Journal, v. 66, no. 6, p. 1947-1956. 
Seitzinger, S., Harrison, J.A., Bohlke, J.K., Bouwman, A.F., Lowrance, R., Peterson, B., Tobias, C., and Van Drecht, G., 2006, Denitrification across landscapes and waterscapes: A synthesis: Ecological Applications, v. 16, no. 6, p. 2064-2090.

Sexstone, A.J., Revsbech, N.P., Parkin, T.B., and Tiedje, J.M., 1985, Direct measurement of oxygen profiles and denitrification rates in soil aggregates: Soil Science Society of America Journal, v. 49, no. 3, p. 645.

Sigman, D.M., Casciotti, K.L., Andreani, M., Barford, C., Galanter, M., and Bohlke, J.K., 2001, A bacterial method for the nitrogen isotopic analysis of nitrate in seawater and freshwater: Analytical Chemistry, v. 73, p. 4145-4153.

Sinreich, M., and Flynn, R., 2011, Comparative tracing experiments to investigate epikarst structural and compositional heterogeneity: Speleogenesis and Evolution of Karst Aquifers, Issue 10, p. 60-67.

Sobczak, W.V., and Findlay, S., 2002, Variation in bioavailability of dissolved organic carbon among stream hyporheic flowpaths: Ecology, v. 83, no. 11, p. 3194-3209.

Starr, R.C., and Gillham, R.W., 1993, Denitrification and organic carbon availability in two aquifers: Ground Water, v. 31, no. 6, p. 934-947.

Steele, K.F., and McCalister, W.K., 1990, Nitrate concentrations of ground water from limestone and dolomitic aquifers in the northeastern Washington County area, Arkansas: Arkansas Water Resources Center MSC-68, 33 p.

St-Jean, G., 2003, Automated quantitative and isotopic $\left({ }^{13} \mathrm{C}\right)$ analysis of dissolved inorganic carbon and dissolved organic carbon in continuous-flow using a total organic carbon analyzer: Rapid Communications in Mass Spectrometry, v. 17, no. 5, p. 419-428.

Sylvia, D.M., Fuhrmann, J.J., Hartel, P.G., and Zuberer, D.A., eds., 1999, Principles and applications of soil microbiology: Upper Saddle River, New Jersey, Prentice Hall, 550 p.

Tenovuo, J., 1986, The biochemistry of nitrates, nitrites, nitrosamines and other potential carcinogens in human saliva: Journal of Oral Pathology, v. 15, no. 6, p. 303-307.

Tiedje, J.M., 1988, Ecology of denitrification and dissimilatory nitrate reduction to ammonium: Biology of Anaerobic Microorganisms, v. 717, p. 179-244.
Van Kessel, J., 1978, Gas production in aquatic sediments in the presence and absence of nitrate: Water Research, v. 12, no. 5, p. 291-297.

Veni, G., DuChene, H., Crawford, N.C., Groves, C.G., Huppert, G.H., Kastning, E.H., Olson, R., and Wheeler, B.J., 2001, Living with karst: A fragile foundation (Environmental Awareness Series ed.): American Geological Institute, 64 p.

Vidon, P., and Hill, A.R., 2005, Denitrification and patterns of electron donors and acceptors in eight riparian zones with contrasting hydrogeology: Biogeochemistry, v. 71, no. 2, p. 259-283.

Winston, B.A., 2006, The biogeochemical cycling of nitrogen in a mantled karst watershed: Fayetteville, University of Arkansas, M.S. Thesis, $88 \mathrm{p}$. 


\title{
Geochemistry of Paleokarst Aquifers of the Knox Group in Tennessee and Kentucky
}

\author{
By Michael Bradley ${ }^{1}$, and Thomas (Marty) Parris ${ }^{2}$ \\ ${ }^{1}$ U.S. Geological Survey, Tennessee Water Science Center, 640 Grassmere Park, Nashville, TN 37211 \\ ${ }^{2}$ Kentucky Geological Survey, 228 Mining and Mineral Resources Building, Lexington, KY 40506
}

\section{Abstract}

Water-quality samples were collected from deep carbonate formations in the Cambrian- and Ordovician-age Knox Group in the central areas of Kentucky and Tennessee as part of an evaluation of the formations for carbon sequestration (Kentucky) and the geohydrology of the paleokarst aquifers (Tennessee). Geochemical data from the deep carbonate formations have been used to evaluate the chemical evolution of the groundwater, residence time, and the degree of confinement. The geochemical data indicate differences in groundwater evolution in the different structural settings including the Nashville Dome, Cincinnati Arch, and Illinois Basin (fig. 1).

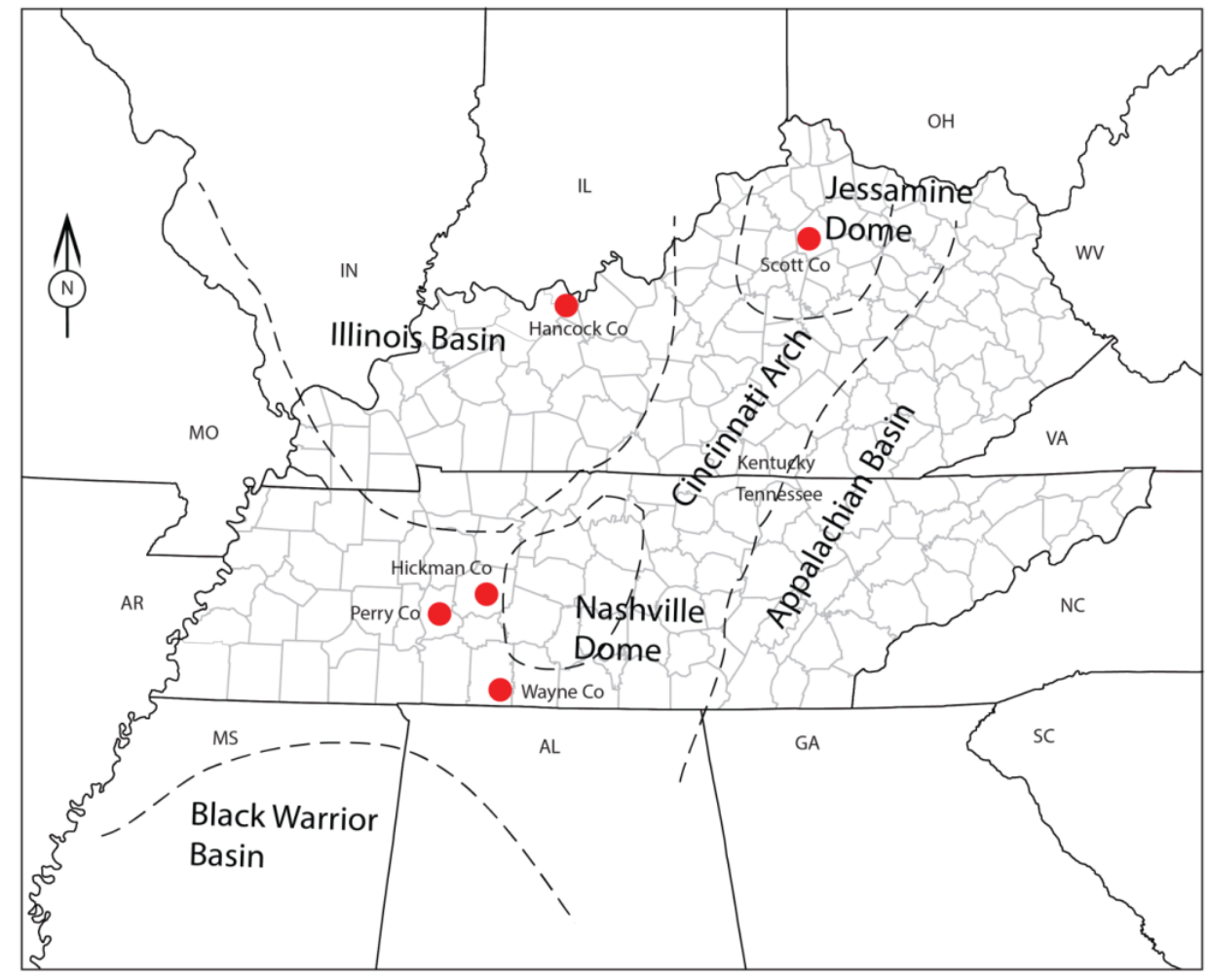

Figure 1. Major geologic structures and locations of selected wells in the Knox Group, Hancock and Scott Counties, Kentucky, and Hickman, Perry, and Wayne Counties, Tennessee.

Geologic units being tested include formations equivalent to the Mascot Dolomite of the upper Knox Group, the Chepultepec Dolomite of the middle Knox Group, and the Copper Ridge Dolomite of the lower Knox Group. The unconformity at the upper contact of the Knox Group is a major stratigraphic break between the lower-middle Ordovician Knox Group and the overlying middle Ordovician carbonates. Paleokarst features present in the Knox Group include secondary porosity and permeability, 
and collapse breccia (fig. 2). Water-quality data from about 900 samples from aquifers in Precambrian- to Pennsylvanian-age geologic units in Kentucky and about 600 samples from aquifers in Cambrian- to Pennsylvanian-age geologic units in Tennessee indicate that groundwater from the Mascot Dolomite of the Knox Group has lower dissolved-solids concentrations than would be expected based on data trends in other aquifers.

Water-quality and geochemical data from recently sampled Knox Group wells along the western side of the Cincinnati Arch in Tennessee and Kentucky indicate a mixing of formation and meteoric waters. Groundwater samples from a well in the Illinois Basin in Kentucky has high dissolved-solids and chloride concentrations that are indicative of possible connate water and long residence time rock-water interaction in the formation. Groundwater from three recently sampled wells in Middle Tennessee, west of the Cincinnati Arch, has relatively low dissolved-solids and chloride concentrations and indicates the presence of relatively young meteoric water in the formation. The stable-isotope $\left(\delta^{18} \mathrm{O}\right.$ and $\left.\delta \mathrm{H}\right)$ values for groundwater from wells in the Nashville Dome and Jessamine Dome are close to the meteoric water line, suggesting the presence and possible mixing with meteoric water (fig. 3). The stable-isotope values for groundwater from a well in Hancock County, plot along an isotopic trend line for the Illinois Basin, indicating rock-water interaction.

\begin{tabular}{|c|c|c|c|}
\hline Location & $\begin{array}{l}\text { Depth below } \\
\text { land surface } \\
\text { (feet) }\end{array}$ & $\begin{array}{c}\delta^{18} \mathrm{O} \\
\text { (permil) }\end{array}$ & $\begin{array}{c}\delta^{2} \mathrm{H} \\
\text { (permil) }\end{array}$ \\
\hline \multicolumn{4}{|l|}{ Illinois Basin } \\
\hline Hancock Co., KY & $3,500-5,000$ & -5.1 to -5.5 & -40.0 to -41.5 \\
\hline \multicolumn{4}{|c|}{ Cincinnati Arch - Jessamine Dome } \\
\hline Scott Co., KY & $1,800-2,100$ & -7.3 to -8.1 & -41 to -57 \\
\hline \multicolumn{4}{|c|}{ Cincinnati Arch - Nashville Dome } \\
\hline Hickman Co., TN & $1,450-3,069$ & -6.26 to -6.35 & -35.6 to -36.0 \\
\hline Wayne Co., TN & $1,200-1,221$ & -5.26 to -5.9 & -28.2 to -35 \\
\hline Perry Co., TN & $4,727-4,960$ & -6.09 & -35.53 \\
\hline
\end{tabular}

Chlorine-36 isotope analysis for water from two wells indicate substantially younger water in the Knox Group in Hickman County, Tennessee (Nashville Dome) than in water from a well in Hancock County, Kentucky (Illinois Basin), which is much older water ( $>1.5$ million years).

The occurrence of lower dissolved solids in water at depth in the Knox Group in Middle Tennessee is indicative of a permeable unit that has some connection with meteoric water. The indicated mixing of formation and meteoric waters and the potential connection with groundwater from shallower aquifers has implications regarding possible carbon sequestration in these formations. Potential recharge and movement of younger, relatively fresh water into and through the Mascot Dolomite indicates the potential for carbon dioxide leakage updip, or possible leakage through fractures in the overlying formations. 
Core interval, in feet below Kelly bushing of drill rig (18.5 feet above land surface)

$$
\text { 2,091-2,092 2,117-2,118 3,130-3,131 }
$$
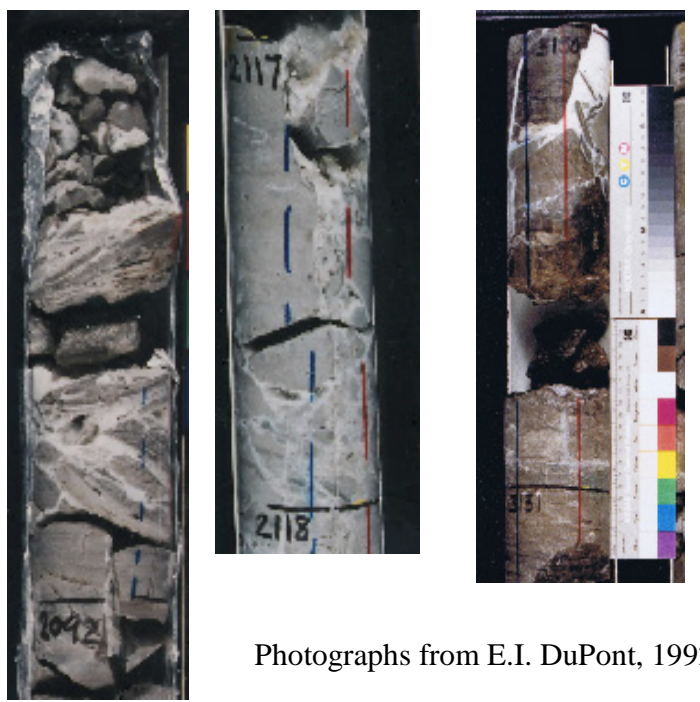

Photographs from E.I. DuPont, 1992

Figure 2. Core photographs from E.I. duPont GHS no. 1 well, Humphreys County, Tennessee, showing paleokarst features with collapse breccia, calcite mineralization, and secondary porosity in the Mascot Dolomite, Knox Group.

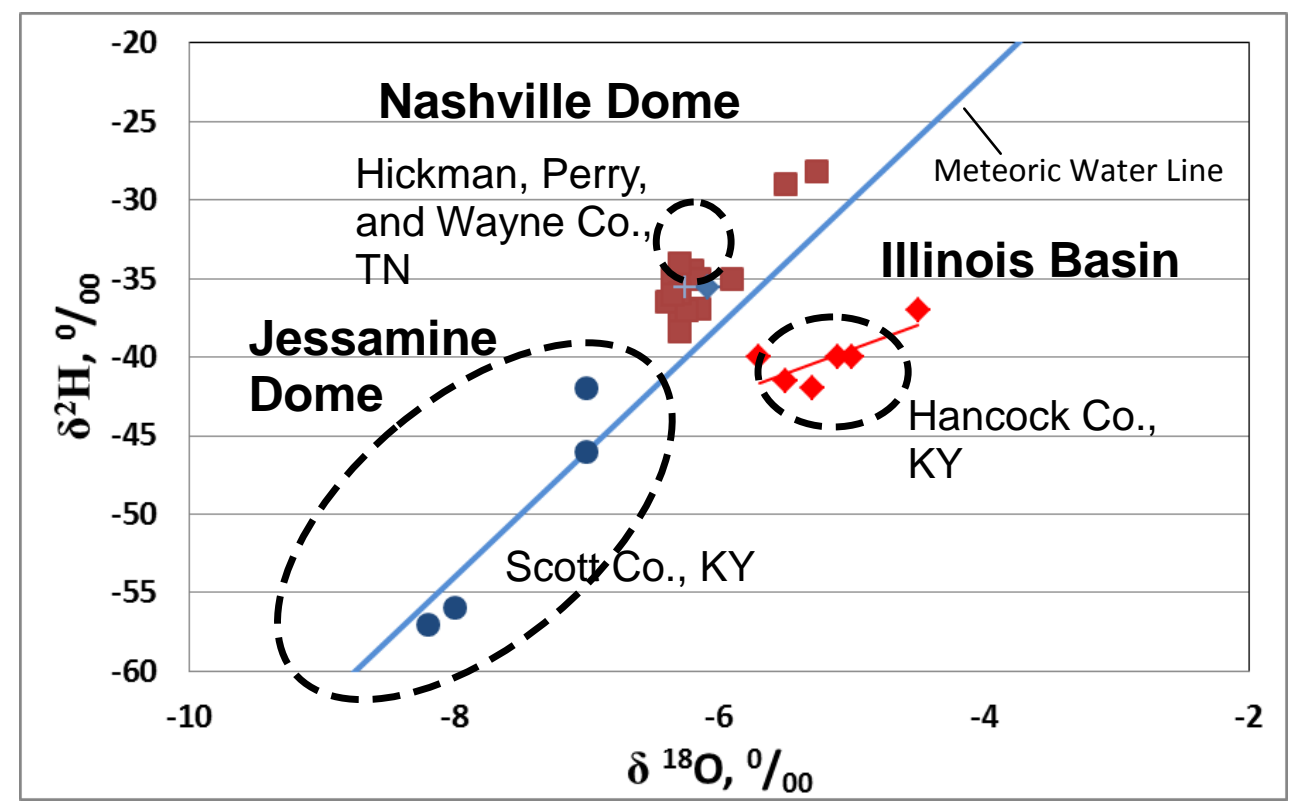

Figure 3. Relation between stable isotope ratios for hydrogen $\left(\delta^{2} \mathrm{H}\right)$ and oxygen $\left(\delta^{18} \mathrm{O}\right)$, in permil $\left({ }^{0}{ }_{00}\right)$, for groundwater from wells in the Knox Group, Kentucky and Tennessee. 


\section{REFERENCES}

Bradley, Michael W., 2001, Geochemistry of the Upper Knox aquifer in Tennessee, in Kuniansky, E.L. (ed.), U.S. Geological Survey Karst Interest Group Proceedings, St. Petersburg, Florida, February 2001: U.S. Geological Survey Water-Resources Investigations Report 01-4011, 211 p.

Bradley, Michael W., and Parris, Thomas, 2012, Geochemistry of deep aquifers in Tennessee and implications for carbon sequestration: Tennessee Section-American Water Resources Association, Proceedings of the $22^{\text {nd }}$ Tennessee Water Resources Symposium, April 2012, Burns, Tennessee, p. 1C-2.

Brahana, J.V., and Bradley, M.W., 1985, Delineation and description of the regional aquifers of Tennessee: The Knox aquifer in central and west Tennessee: U.S. Geological Survey Water-Resources Investigations Report 83-4012, $32 \mathrm{p}$.

Clark, I.D., and Fritz, P., 1997, Environmental isotopes in hydrogeology: Boca Raton, Florida, CRC Press, 328 p.

E.I. DuPont, 1992, Geohydrological survey well, Johnsonville plant, Book 2 of 2, Mascot Dolomite \#3: E.I. duPont de Nemours, Inc., New Johnsonville, Tennessee.

Ford, Derek, and Williams, Paul, 2007, Karst hydrology and geomorphology: West Sussex, England, John Wiley and Sons, Ltd., 562 p.

Gragg, Michael, and Perfect, Ed, 2011, Rock core sample porosity testing for the Knox Group-Stones River Group carbon dioxide storage assessment unit in Tennessee: Department of Earth and Planetary Sciences, University of Tennessee-Knoxville, Report to the Tennessee Division of Geology, 18 p.

James, N.P., and Choquette, P.W., eds., 1988, Paleokarst: Berlin-Heidelberg, Springer-Verlag, 416 p.

Kipp, James A., 1997, Fresh-water aquifer in the Knox Group (Cambrian-Ordovician) of central Kentucky: Kentucky Geological Survey Report of Investigations 12, Series XL, 15 p.

Parris, Thomas, and Bradley, Michael W., 2012, Fluid evolution in Cambrian-Ordovician Knox Group reservoirs: Kentucky Water Resources Research Institute, Kentucky Water Resources Annual Symposium, March 19, 2012, Lexington, Kentucky, p. 55-56.

Tennessee Division of Geology, 2011, Regional east-west and north-south cross sections across Tennessee from the eastern escarpment of the Cumberland Plateau province to the Mississippi Embayment: Tennessee Division of Geology, prepared for the U.S. Geological Survey National Geologic $\mathrm{CO}_{2}$ Sequestration Assessment, $1 \mathrm{pl}$.

U.S. Department of Energy, 2013, NATCARB-National carbon sequestration database and geographic information system: U.S. Department of Energy, accessed February 21, 2014, at http://www.netl.doe.gov/research/coal/carbon-storage/carbon-storage-natcarb 


\title{
Integration of Geochemical and Isotopic Data to Assess Sources of Discharge at a Major Spring in the Edwards Aquifer, South-Central Texas
}

\author{
By MaryLynn Musgrove ${ }^{1}$ and Cassi L. Crow ${ }^{2}$ \\ ${ }^{1}$ U.S. Geological Survey, 1505 Ferguson Ln., Austin, TX 78754 \\ ${ }^{2}$ U.S. Geological Survey, 5563 DeZavala Rd., Ste. 290, San Antonio, TX 78249
}

\begin{abstract}
The Edwards aquifer in south-central Texas is a productive and important water resource. Several large springs issuing from the aquifer are major discharge points, popular locations for recreational activities, and habitat for threatened and endangered species. Discharge amounts from Comal and San Marcos Springs, the first and second largest spring complexes in Texas, are used as thresholds in groundwater management strategies. It is generally understood that Comal Springs is predominantly supplied by regional groundwater flow paths; however, the hydrologic connection of San Marcos Springs with the regional flow system is less understood. During November 2008-December 2010, the U.S. Geological Survey conducted a hydrologic and geochemical investigation of San Marcos Springs to define and characterize its sources of discharge. During the study, hydrologic conditions transitioned from exceptional drought to wetter than normal, which provided the opportunity to investigate the hydrogeology of San Marcos Springs under a wide range of hydrologic conditions. Water samples were collected from streams, groundwater wells, and springs at and near San Marcos Springs, including periodic sampling (every 3 to 7 weeks) and sampling in response to storms. Additionally, selected physicochemical properties were measured continuously at several orifices of San Marcos Springs. The integration of geochemical and isotopic data with geochemical modeling allowed for distinguishing and quantifying sources of discharge at San Marcos Springs. Results indicate that discharge at San Marcos Springs was dominated by regional recharge sources and flow paths, and that the contribution from local streams was relatively minor. Different orifices of San Marcos Springs responded differently to changes in hydrologic conditions. Some orifices are influenced by mixing with a component of saline groundwater, likely from the downdip Edwards aquifer saline zone. Results of this study are useful for resource management strategies and for understanding geochemical and hydrologic processes that affect the Edwards aquifer.
\end{abstract}




\title{
MICROBIAL ECOLOGY AND KARST ECOSYSTEMS
}

\section{Linking Climate Change and Karst Hydrology to Evaluate Species Vulnerability: The Edwards and Madison Aquifers}

\author{
By Barbara J. Mahler ${ }^{1}$, Andrew J. Long ${ }^{2}$, John F. Stamm², Mary F. Poteet ${ }^{3}$, and Amy J. \\ Symstad $^{4}$ \\ ${ }^{1}$ U.S. Geological Survey, 1505 Ferguson Ln., Austin, TX 78751 \\ ${ }^{2}$ U.S. Geological Survey, 1608 Mountain View Rd., Rapid City, SD 57702 \\ ${ }^{3}$ University of Texas at Austin, 1 University Station G2500, C0930, Austin, TX 78712 \\ ${ }^{4}$ U.S. Geological Survey, Northern Prairie Wildlife Research Center, $871137^{\text {th }}$ Street SE, Jamestown, ND \\ 58401
}

\begin{abstract}
Karst aquifers present an extreme case of flow along structurally variable pathways, making them highly dynamic systems and therefore likely to respond rapidly to climate change. In turn, many biological communities and ecosystems associated with karst are sensitive to hydrologic changes. We explored how three sites in the Edwards aquifer (Texas) and two sites in the Madison aquifer (South Dakota) might respond to projected climate change from 2011 to 2050. Ecosystems associated with these karst aquifers support federally listed endangered and threatened species and state-listed species of concern, including amphibians, birds, insects, and plants. The vulnerability of selected species associated with projected climate change was assessed.
\end{abstract}

The Advanced Research Weather and Research Forecasting (WRF) model was used to simulate projected climate at a 36-kilometer grid spacing for three weather stations near the study sites, using boundary and initial conditions from the Community Climate System Model (CCSM3), a global climate model, and an A2 emissions scenario. Daily temperature and precipitation projections from the WRF model were used as input for the hydrologic Rainfall-Response Aquifer and Watershed Flow (RRAWFLOW) model and the Climate Change Vulnerability Index (CCVI) model. RRAWFLOW is a lumped-parameter model that simulates hydrologic response at a single site, combining the responses of quick and slow flow that commonly characterize karst aquifers. The CCVI model uses historical and projected climate and hydrologic metrics to determine the vulnerability of selected species on the basis of species exposure to climate change, sensitivity to factors associated with climate change, and capacity to adapt to climate change.

An upward trend in temperature was projected for 2011 to 2050 at all three weather stations; there was a trend (downward) in annual precipitation only for the weather station in Texas. A downward trend in mean annual springflow or groundwater level was projected for all of the Edwards aquifer sites, but there was no significant trend for the Madison aquifer sites. Of 16 Edwards aquifer species evaluated (four amphibians, six arthropods, one fish, one mollusk, and four plants), 12 were scored as highly or moderately vulnerable under the projected climate change scenario. In contrast, all of the eight Madison aquifer species evaluated (two mammals, one bird, one mollusk, and four plants) were scored as moderately vulnerable, stable, or intermediate between the two. The inclusion of hydrologic projections in the vulnerability assessment was essential for interpreting the effects of climate change on aquatic species of conservation concern, such as endemic salamanders. The linkage of climate, hydrologic, and vulnerability models provided a bridge to project the effects of global climate change on local karst aquifer and stream systems, and selected species. 


\title{
Response of Cave-Stream Bacteria to Sub-Lethal Concentrations of Antibiotics
}

\author{
By Thomas D. Byl ${ }^{1}$, Petra K. Byl ${ }^{1^{*}}$, Shannon Trimboli ${ }^{2}$, and Rickard Toomey, $\mathrm{III}^{2}$ \\ ${ }^{1}$ U.S. Geological Survey, 640 Grassmere Park, Suite 100, Nashville, TN 37209 (*Volunteer for Science) \\ ${ }^{2}$ Mammoth Cave International Center for Science and Learning, Science \& Resource Management, \\ Mammoth Cave National Park, KY 42259
}

\begin{abstract}
Mammoth Cave National Park (MACA) in central Kentucky, is a world renowned karst system that attracts over 500,000 tourists per year. The high volume of tourists contributes to incidental surface releases of soaps and disinfectants at the waste-transfer station for recreational vehicles and the biosecurity mats used to reduce the spread of Pseudogymnoascus destructans (formerly known as Geomyces destructans, the fungus that causes white nose syndrome (WNS) in bats) spores on footwear. Multi-antibiotic resistant (MAR) bacteria were reported in high numbers around the waste-transfer station and WNS disinfection stations. Additionally, some disinfectant was observed in the cave streams after a storm. The potential problems identified by these observations led to a study by the U.S. Geological Survey (USGS), in partnership with MACA and Tennessee State University, to determine substrate utilization patterns and antibiotic resistance of microbial communities associated with cave streams at different levels of passages in the historic section of Mammoth Cave.

The cave streams within MACA were targeted because they represent a hydrologic connection between land surface and the cave system. Storm water runoff carries suspended and dissolved constituents from the surface or near surface into the cave. The suspended and dissolved constituents can either be toxic, immaterial, or serve as food for microbes and other organisms that live in the subsurface streams. However, very little is known about the microbial community in cave streams, the food preference, or the response to anti-microbial compounds by the cave-stream bacteria. Water samples were collected at one surface and seven cave sites in the summer of 2012 through the fall of 2013. The surface sampling was limited to storm events due to lack of flow between storms. The cave-stream sampling sites had continuous flow and were sampled during and between storms. The sampling sites were located on different vertical levels of the cave system: three sites in the upper mid-level passages, two in the lower mid-level passages, and two in the deeper levels of the cave.
\end{abstract}


Bacterial sensitivity to antibiotics was quantified using agar plates with 10-percent trypticase soy agar (10-percent TSA) augmented with 0.00, 0.01, 0.1, 1.0, and 10.0 milligrams per liter (mg/L) antibiotic (erythromycin, kanamycin, gentamicin, tetracycline, linear alkylbenzene sulfonates, or quaternary ammonia compounds). Bacteria resistant to antibiotic existed in all levels of the cave. However, the number of colony forming units (cfu) on the 10-percent TSA plates generally decreased as the antibiotic dosage increased. One exception to this pattern was erythromycin, which significantly $(p<0.05)$ increased the number of bacteria colonies in agar supplemented with 0.1 and $1.0 \mathrm{mg} / \mathrm{L}$ erythromycin in samples collected from Lee's Cistern, Shaler's Brook, and Charlotte's Dome within the historic section of Mammoth Cave. Biolog EcologTM (Ecolog) plates with 31 different substrates were used to evaluate community substrate utilization patterns. The waters used to inoculate the Ecolog plates were standardized by turbidity to reduce disparity between inoculum bacteria concentrations. This standardization was confirmed with plate counts. Bacterial community samples collected deeper in the cave tended to use fewer substrates than those collected from or near the surface. Bacterial communities from the lower passages had a lower average well color development with the exception of Charon's Cascade, located on the lowest level of the cave. It is possible that bacteria from Charon's Cascade did not conform to the pattern because the lowest level of the cave floods with backwater from the Green River on occasion. The results of the investigation suggest that microbial communities have different antibiotic resistance and substrate utilization patterns associated with different locations in the cave stream. 


\title{
Role of Surface Water Dissolved Organic Carbon in the Survival, Growth, and Transport of Escherichia coli in a Deep Limestone Aquifer in South Florida
}

\author{
By Ronald W. Harvey ${ }^{1}$, Jen Underwood ${ }^{1}$, John Lisle ${ }^{2}$, David W. Metge ${ }^{1}$, and \\ George Aiken ${ }^{1}$ \\ ${ }^{1}$ U.S. Geological Survey, National Research Program, 3215 Marine St., Suite E-127, Boulder, CO 80303 \\ ${ }^{2}$ U.S. Geological Survey, 600 4th Street-South, St. Petersburg, FL 33701
}

\begin{abstract}
Much is unknown about survival and activities of bacteria within deep aquifers hydrologically isolated from surface-water intrusion. Groundwater about 15,000-20,000 years old was collected from $317-482$ meters below land surface in the subtropical $\left(22^{\circ} \mathrm{C}\right)$ Floridan aquifer in southeast Florida. Dissolved organic carbon (DOC), often a major control of heterotrophic activity in shallow aquifers, had a low concentration (1.1 milligrams per liter). Its low specific ultraviolet (UV) absorbance (2.2) and high fluorescence index (1.8) indicated only modest aromaticity and a likely microbial (versus terrestrial) origin. Surface properties and growth of Escherichia coli (E. coli) K12 were both affected by the presence of the hydrophobic organic acid (HPOA) fraction of DOC in surface waters to be used in regional aquifer storage and recovery (ASR). Collectively, the effect of surface water DOC on the growth and surface properties of $E$. coli K12 is predicted to alter its fate in the Floridan aquifer.
\end{abstract}

\section{INTRODUCTION}

A concern regarding deep-well injection of wastewater and planned expansion for aquifer storage and recovery (ASR) in south Florida is the effect of highly reactive dissolved organic carbon (DOC) on aquifer microbiology, particularly as it affects survival and transport of pathogenic and indicator bacteria. Plans for ASR involve a seasonal injection of about 6 billion liters per day of surface water into the upper Floridan aquifer. Organic-rich (17 milligrams per liter [mg/L] DOC) Lake Okeechobee (1,714 $\mathrm{km}^{2}$ ) is likely to be an important source of surface water for injection into the Floridan aquifer (Wedderburn and others, 2013). There are many factors that affect the survival of bacterial pathogens and indicators in groundwater, including levels of nutrients, temperature, ionic strength/salinity, redox conditions, presence/absence of biofilms, environmental microbial diversity and ecology, physicochemical characteristics of the solid phase, and the character and concentration of DOC. In very old, carbon-limited groundwater such as that present in the Floridan aquifer, levels and lability of the DOC can be important controls of growth, survival, and transport for non-native bacteria that are introduced during the ASR process.

\section{DOC and Survival}

Unfortunately, most studies of bacterial survival in subsurface environments involve very limited set(s) of conditions. Transport of bacteria from surface waters through a vadose zone into an underlying aquifer necessitates survival in several environments that have very different conditions. Consequently, survival over the entire transport pathway is exceedingly difficult to predict.

Even when conditions favor rapid die-off of the bulk population of pathogens, some subpopulations can persist for long periods. Many bacterial pathogens and indicators, including Escherichia coli (E. coli) and Pseudomonas aeruginosa, are able to enhance their survival in low-carbon environments by entering a pseudodormant state, termed "viable but nonculturable" (VBNC) (Oliver, 2010). The VBNC state, which can be classified as a persistent phenotype, is an adaptation to survival under variable environmental conditions (Rotem and others, 2010) and can be triggered by environmental factors, such as lack of labile DOC. Cook and Bolster (2007) demonstrated that E. coli in groundwater transitioned into a VBNC state characterized by changes in morphology and a reduced rate of respiration in response to 
starvation. Most studies involving environmental survival of bacterial pathogens use culture-based methods, which underestimate survival of bacterial pathogens that transition into and out of the VBNC state. However, Lisle (2014) has shown that for the Floridan aquifer, die-off of coliform bacteria can be considerably more rapid than previously believed.

The activities of indigenous subsurface microorganisms, which depend, in part, on the levels and character of the DOC, can enhance or inhibit the survival of bacterial pathogens and indicators. For example, biofilm formation has been shown to favor pathogen survival under both typical environmental conditions and under active disinfection (Murphy and others, 2006). Conversely, competition for limited DOC is known to inhibit pathogen survival (Crane and Moore, 1986). Bacteriophages are abundant and ubiquitous in nature (Kimura and others, 2008) and can impact host bacterial populations by lysis of cells and by altering the host phenotype via genetic alterations (Dröge and others, 1999). It is likely that coliphages play an antagonistic role in the survival of coliform bacteria in many aquifers, although the roles of protozoa in the survival of bacterial pathogens in the subsurface are not well understood. However, it is known that the diverse communities of nanoflagellates in aquifers (Novarino and others, 1997) can be a significant sink for bacteria being advected from the surface environment (Kinner and others, 1997; Kinner and others, 1998). The role of predation appears to increase where there are substantive inputs of labile DOC (Kinner and others, 2002), because the protozoan community is stimulated by the resulting bacterial growth.

\section{DOC and Growth}

The ability of bacterial pathogens to grow in the environment has been a topic of considerable debate. The degree of growth depends upon the environmental conditions and the specific pathogen of interest. Some bacterial pathogens, such as Campylobacter jejuni are typical inhabitants of some subsurface environments and are expected to proliferate in-situ under conditions that are most favorable, i.e., optimal nutrients, substrates, temperature, and lack of competition and predation. Growth in the environment of non-indigenous bacterial pathogens is sometimes referred to as "regrowth" (Zaleski and others, 2005), as it is suspected to occur if the optimal growth conditions are met.

We examined the effect of Lake Okeechobee DOC upon the surface properties, growth, and survival of $E$. coli K12. Although $E$. coli is generally considered incapable of growing outside a mammalian host (Avery and others, 2008), it may be able to grow in tropical and temperate soils (Ishii and Sadowsky, 2008). In this study, Lake Okeechobee DOC (hydrophobic organic acid [HPOA] fraction, 20 $\mathrm{mg} / \mathrm{L}$ ), caused growth of $E$. coli K12 relative to unamended artificial lake water (ALW) devoid of DOC (fig. 1). This suggests that DOC introduced during ASR could affect survival of bacterial indicators and, possibly, certain bacterial pathogens.

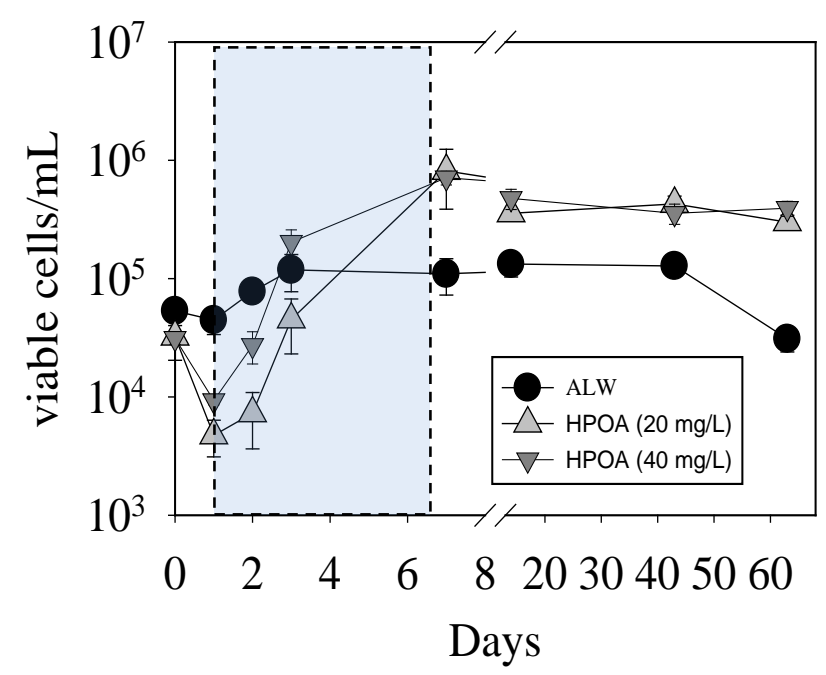

Figure 1. Growth of Escherichia coli K12 in the absence of DOC (ALW) and in the presence of $20 \mathrm{mg} / \mathrm{L}$ and $40 \mathrm{mg} / \mathrm{L}$ of the more aromatic hydrophobic organic acid (HPOA) fraction of the DOC. The study was conducted using a laboratory microcosm with artificial lake water (ALW). Shaded section indicates period of observed bacterial growth.

\section{DOC and Transport}

The effect of surface-water derived DOC, both natural organic matter (NOM) and organic contaminants, on transport of bacteria through the aquifers subject to ASR or deep-well wastewater injection has important public health 
and environmental implications. Elevated levels of labile DOC can affect the surface characteristics of bacterial pathogens and, consequently, their transport behavior in the aquifer. The ability of humic material to enhance advective bacterial transport through aquifer material has been well documented (Foppen and others, 2008). However, to assess the role of DOC in bacterial transport at the field scale, it is useful to consider also the contributions of contaminant organic compounds that may also be present in surface waters and can affect bacterial attachment behavior at "trace" levels (Harvey and others, 2010). Although the majority of studies examining the roles of DOC on subsurface microbial transport indicate decreased attachment and increased transport, some organics have the opposite effect (Marshall and others, 2000). Undoubtedly, the extent to which DOC facilitates or inhibits bacterial transport is dependent upon a complex suite of interactions involving the nature of the DOC, physicochemical conditions, aqueous chemistry, and the surface characteristics of the bacteria and solid phase. Consequently, use of model organic compounds bacterial transport studies involving ASR or deep-well injection can lead to misleading results compared to the use of DOC isolated directly from the source water.

We examined the role of the HPOA fraction of Lake Okeechobee DOC upon two important surface characteristics of $E$. coli K12 that affect its propensity for attachment: hydrophobicity and surface charge (table 1). The presence of surface-water derived DOC had a substantive effect on the net surface charge of E. coli K12, decreasing the zeta potential about 4-fold from -88 to -22 millivolts. The decrease in the surface charge in the presence of Lake Okeechobee HPOA would have the effect of making $E$. coli K12 more likely to attach to aquifer surfaces characterized by net negative charge. This is due to a decreased electrostatic repulsion between the cell surface and the solid phase. However, the decreased surface charge would make $E$. coli K12 less likely to attach to aquifer surfaces characterized by patches of net positive charge in the form of aluminum and iron oxides. The decreased hydrophobicity of E. coli K12 in the presence of HPOA from 26 to 18 percent should enhance transport in the aquifer by decreasing the propensity for partitioning to the solid phase. Results of bacterial attachment in the presence of aquifer material and Lake Okeechobee DOC were inconclusive. Clearly, the role of surface water DOC upon transport of indicator bacteria in the Floridan aquifer is complex and worthy of further study. However, our findings suggest that the effect of surface water DOC on the fate and transport of non-native bacteria that are introduced inadvertently during ASR should not be ignored.

Table 1. Effect of Lake Okeechobee dissolved organic carbon on Escherichia coli K12 surface properties.

\section{Dissolved Organic Carbon (DOC)}

${ }^{3}$ Hydrophobic Organic Acid (HPOA) fraction

No DOC

${ }^{1}$ Microbial adhesion to hydrocarbon test.

${ }^{2}$ Measured at ionic strength of $0.01 \mathrm{M}$ (moles per liter).

${ }^{3}$ Concentration of $40 \mathrm{mg} / \mathrm{L}$ (milligrams per liter).
Surface charge

Hydrophobicity ('MATH test) ( ${ }^{2}$ zeta potential)

$18.0 \pm 2.3$ percent

$-22.0 \pm 2.6$ millivolts

$26.1 \pm 4.9$ percent

$-88.5 \pm 2.0$ millivolts 


\section{REFERENCES}

Avery, L.M., Williams, A.P., Killham, K., and Jones, D.L., 2008, Survival of Escherichia coli O157:H7 in waters from lakes, rivers, puddles and animaldrinking troughs: Science of the Total Environment, v. 389, p. 378-385.

Cook, K.L., and Bolster, C.H., 2007, Survival of Campylobacter jejuni and Escherichia coli in groundwater during prolonged starvation at low temperatures: Journal of Applied Microbiology, v. 103, p. 573-583.

Crane, S.R., and Moore, J.A., 1986, Modeling enteric bacterial die-off: A review: Water, Air, \& Soil Pollution, v. 27, p. 411-439.

Dröge, M., Pühler, A., and Selbitschka, W., 1999, Horizontal gene transfer among bacteria in terrestrial and aquatic habitats as assessed by microcosm and field studies: Biology and Fertility of Soils, v. 29, p. 221-245.

Foppen, J.W., Liem, Y., and Schijven, J., 2008, Effect of humic acid on the attachment of Escherichia coli in columns of goethite-coated sand: Water Research, v. 42, p. 211-219.

Harvey, R.W., Metge, D.W., Barber, L.B., and Aiken, G.R., 2010, Effects of altered groundwater chemistry upon the $\mathrm{pH}$-dependency and magnitude of bacterial attachment during transport within an organically contaminated sandy aquifer: Water Research, v. 44, p. 10621071.

Ishii, S., and Sadowsky, M.J., 2008, Escherichia coli in the environment: Implications for water quality and human health: Microbes and Environments, v. 23, p. 101-108.

Kimura, M., Jia, Z.J., Nakayama, N., and Asakawa, S., 2008, Ecology of viruses in soils: Past, present and future perspectives: Soil Science \& Plant Nutrition, v. 54, p. 1-32.

Kinner, N.E., Harvey, R.W., Blakeslee, K., Novarino, G., and Meeker, L.D., 1998, Sizeselective predation on groundwater bacteria by nanoflagellates in an organic-contaminated aquifer: Applied and Environmental Microbiology, v. 64, p. 618-625.

Kinner, N.E., Harvey, R.W., and KazmierkiewiczTabaka, M., 1997, Effect of flagellates on freeliving bacterial abundance in an organically contaminated aquifer: FEMS Microbiology Reviews, v. 20, p. 249-259.
Kinner, N.E., Harvey, R.W., Shay, D.M., Metge, D.W., and Warren, A., 2002, Field evidence for a Protistan role in an organically-contaminated aquifer: Environmental Science \& Technology, v. 26, p. 4312-4318.

Lisle, J., 2014, Survival of bacterial indicators and the functional diversity of native microbial communities in the Floridan aquifer system, south Florida: U.S. Geological Survey Open-File Report 2014-1001, 70 p.

Marshall, S.J., House, W.A., and White, G.F., 2000, Role of natural organic matter in accelerating bacterial biodegradation of sodium dodecyl sulfate in rivers: Environmental Science \& Technology, v. 34, p. 2237-2242.

Murphy, C., Carroll, C., and Jordan, K.N., 2006, Environmental survival mechanisms of the foodborne pathogen Campylobacter jejuni: Journal of Applied Microbiology, v. 100, p. 623632.

Novarino, G., Warren, A., Kinner, N.E., and Harvey, R.W., 1994, Protists from a sewage-contaminated aquifer on Cape Cod, Massachusetts, U.S.A.: Geomicrobiology Journal, v. 12, p. 23-36.

Oliver, J.D., 2010, Recent findings on the viable but nonculturable state in pathogenic bacteria: FEMS Microbiological Reviews, v. 34, p. 415-425.

Rotem, E., Loinger, A., Ronin, I., Levin-Reisman, I., Gabay, C., Shoresh, N., Biham, O., and Balaban, N.Q., 2010, Regulation of phenotypic variability by a threshold-based mechanism underlies bacterial persistence: Proceedings of the National Academy of Sciences, v. 107, p. 12541-12546.

Wedderburn, L.A., Linstrom, L., Lukasiewicz, J., Kwiatkowski, P., Nevulis, R., Goodwin, C.R., Cunningham, K.J., Renken, R.A., and Reese, R.S., 2013, What is aquifer storage \& recovery? http://sofia.usgs.gov/sfrsf/rooms/hydrology/ASR/

Zaleski, K.J., Josephson, K.L., Gerba, C.P., and Pepper, I.L., 2005, Potential regrowth and recolonization of salmonellae and indicators in biosolids and biosolid-amended soil: Applied and Environmental Microbiology, v. 71, p. 37013708. 


\section{Cave Bacteria and Crystal Formation in the Laboratory}

By Petra K. Byl ${ }^{1^{\star}}$, Aaron Covey ${ }^{2}$, Jessica Oster ${ }^{2}$, Tasneem Siddiquee ${ }^{3}$, and

Thomas D. Byl $1^{1,3}$

${ }^{1}$ U.S. Geological Survey, 640 Grassmere Park, Suite 100, Nashville, TN 37209 ( ${ }^{*}$ olunteer for Science)

${ }^{2}$ Earth \& Environmental Sciences, Vanderbilt University, Nashville, TN 37240

${ }^{3}$ Tennessee State University, 3500 John A Merritt Blvd., Nashville, TN 37209

Abstract

Speleothems (secondary cave mineral deposits) are used as recorders of past climate change, but little is known about the role microbes may play in biocrystallization as well as modifying trace element microclimate records. This study serves to explore microbe-mineral interactions through analyzing bacteria endemic to Blue Spring Cave, Tennessee and Mammoth Cave, Kentucky. Microorganisms were swabbed from active stalagmite growth in Blue Spring and Mammoth Cave, and later suspended in a liquid culture media, or streaked onto the same agar media in aerobic conditions under constant temperature. The media were an amalgam of chitin-mineral salts media (0.04 percent chitin) and traditional actinomycete isolation media with 0.1 percent ammonia acetate. Bacterial exposure to the ammonia and phosphate salts, both present in the media, caused the biologically mediated precipitation of orthorhombic white crystals as evidenced by the lack of precipitates in the sterile control media. The crystals were identified through $\mathrm{x}$-ray diffraction, energy dispersive spectroscopy, and scanning electron microscopy, and were determined to be struvite $\left(\mathrm{NH}_{4} \mathrm{MgPO}_{4} * 6 \mathrm{H}_{2} \mathrm{O}\right)$ as well as calcite $\left(\mathrm{CaCO}_{3}\right)$. The calcite rhombs were about $10 \mu \mathrm{m}$ in length and appeared to form clusters within the biofilm, while the struvite orthorhombic crystals averaged $250 \mu \mathrm{m}$ in length and did not appear in conglomerates. In cave settings, struvite is naturally found in areas of high bat guano concentration, and calcite deposits over time form the speleothems that paleoclimatologists study. The results indicate that the microorganisms from active stalagmites have the potential, in the presence of ammonia and phosphate, to affect the precipitation and mineral composition of speleothems. 


\title{
Non-Target Bacterial Response to White-Nose Syndrome Treatment: Quaternary Ammonia Compounds and Linear Alkylbenzene Sulfonate
}

\author{
By JeTara Brown ${ }^{1}$, Zheer Ahmed $^{2 *}$, and Thomas D. Byl ${ }^{1,2}$ \\ ${ }^{1}$ Tennessee State University, 3500 John A Merritt Blvd., Nashville, TN 37209 \\ ${ }^{2}$ U.S. Geological Survey, 640 Grassmere Park, Suite 100, Nashville, TN 37209 (*Volunteer for Science)
}

\begin{abstract}
White-Nose Syndrome (WNS) is decimating the North American bat population in many caves east of the Mississippi River. Tour caves, such as those in Mammoth Cave National Park in Kentucky, are trying to prevent the spread of this disease by requiring all visitors coming out of the caves to disinfect their footwear. From April 2011 through early 2013, everyone who entered the cave at Mammoth Cave National Park on a walking tour was required to walk across biosecurity mats soaked with the chemical disinfectant quaternary ammonia compounds (QAC). The National Park Service switched from a QACbased product in 2013 to a laundry detergent containing the anionic surfactant linear alkylbenzene sulfonate (LAS). LAS has been shown to inhibit growth of the fungus that causes WNS at regular strength concentrations. Both chemicals (QAC and LAS) can have a detrimental effect on other organisms besides WNS fungal spores. The U.S. Geological Survey (USGS) Tennessee Water Science Center in partnership with Mammoth Cave National Park and Tennessee State University conducted a study to determine the effect of QAC and LAS on non-target bacteria.
\end{abstract}

The heavily used biosecurity mats were soon colonized by non-target bacteria that had adapted to the chemicals and could use the QAC or LAS as a food source. The QAC-resistant bacteria had multiple antibiotic resistance (MAR) to clinical concentrations of erythromycin, gentamicin, ampicillin, tetracycline, and kanamycin. The QAC-resistant bacteria were generally Gram-negative and rod shaped. Twelve liquid microcosms were established using 250 milliliters of raw liquid from the two times fullstrength QAC-soaked mats. Half the microcosms had sterile marbles added to increase the surface area 2.6 times compared to the other microcosms. The microcosms were placed on a rotary shaker at $75 \mathrm{rpm}$ and maintained at $25{ }^{\circ} \mathrm{C}$. The microcosms with higher surface area for biofilm development had a QAC half-life of 11 days. The microcosms with less surface area had a QAC half-life of 37 days. After switching to LAS, the bacteria collected from the biosecurity mats were again susceptible to antibiotics, with some minor resistance to gentamicin and kanamycin. The predominant LAS-associated bacteria were Gram-negative and cocci shaped.

The bacteria grew on agar plates containing only LAS, indicating they readily consumed the anionic surfactant as a food source. The LAS-soaked mats also produced an unpleasant odor during the warm summer months. Additional tests focused on ways to rid the mats of these nuisance bacteria. Clean sponges were inoculated by placing them under the LAS-soaked mats for 4 hours during busy tour hours, and then exposing these sponges to different cleaning scenarios. Waters extracted from the sponges were then tested for culturable bacteria using 10-percent trypticase soy agar media. A 20-minute exposure to bleach at one-tenth the recommended laundry strength at $25{ }^{\circ} \mathrm{C}$ eliminated the bacteria. Hydrogen peroxide at 0.3 percent was also effective after a 45 -minute exposure. Soaking the sponges in water with no chemicals at $50{ }^{\circ} \mathrm{C}$ for 45 minutes also eliminated all bacteria growth. Full strength ammonia cleaners at $25{ }^{\circ} \mathrm{C}$ did not significantly reduce the number of colonies. The results of these studies help us understand several of the unintentional risks of using chemicals to disinfect WNS spores on footwear, and ways to reduce some of the detrimental side effects. 


\section{THURSDAY, MAY 1, 2014, FIELD TRIP GUIDE}

\section{Evaporite Karst of the Lower Pecos Valley, New Mexico}

\section{By Lewis Land}

New Mexico Bureau of Geology and Mineral Resources, 801 Leroy PI, Socorro, New Mexico 87801 and

National Cave and Karst Research Institute, 400-1 Cascades Avenue, Carlsbad, New Mexico 88220

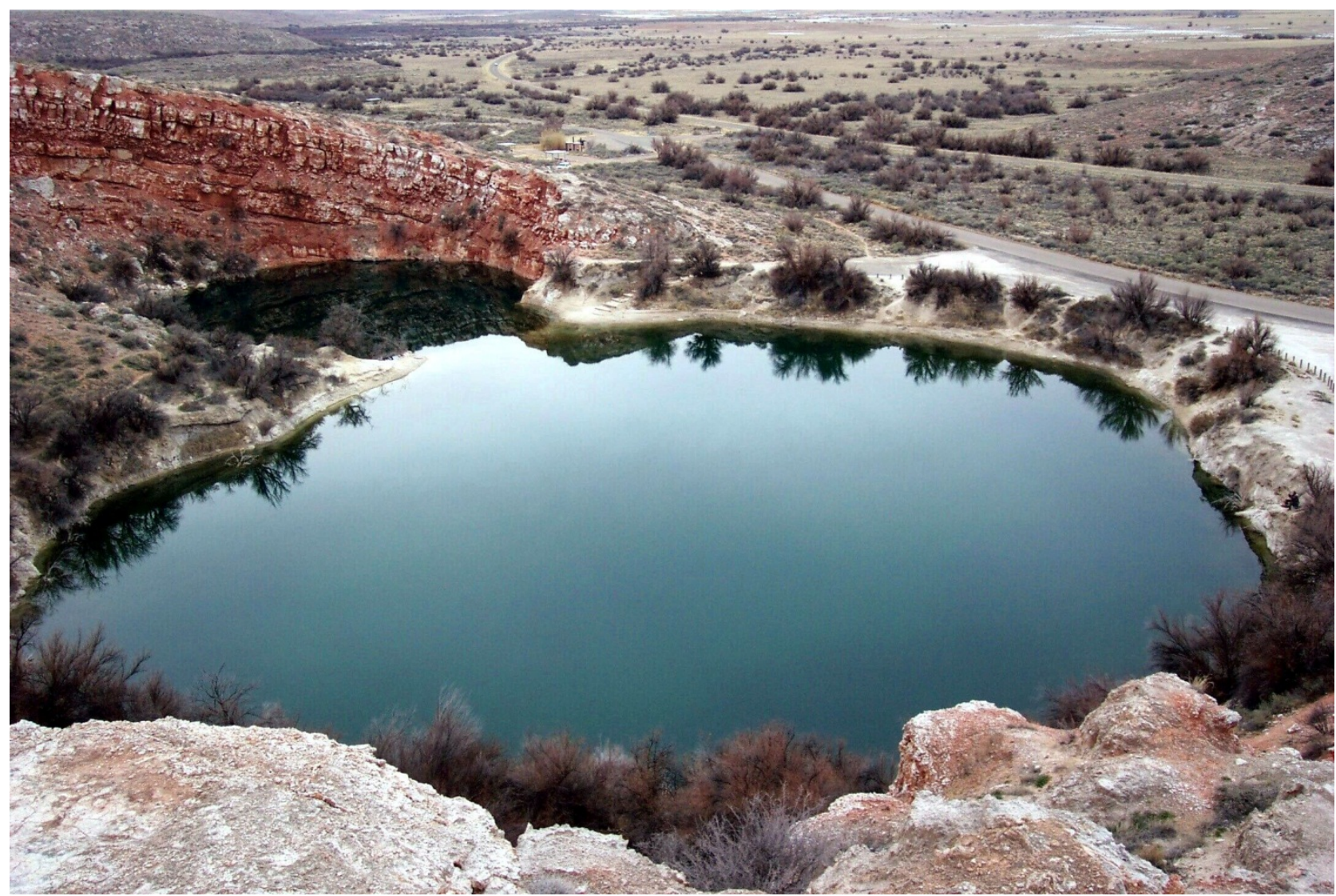

Overview of Mirror Lake, Bottomless Lakes State Park, Chaves Co., New Mexico; view to south. Photo courtesy of Lewis Land, National Cave and Karst Research Institute. 


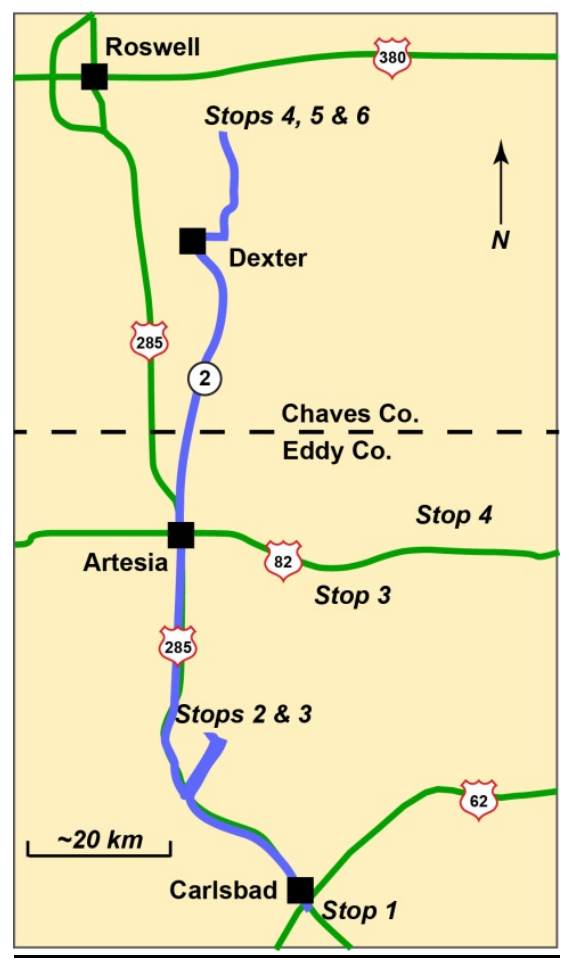

Figure 1. Map of field trip route.

$\mathbf{N}$

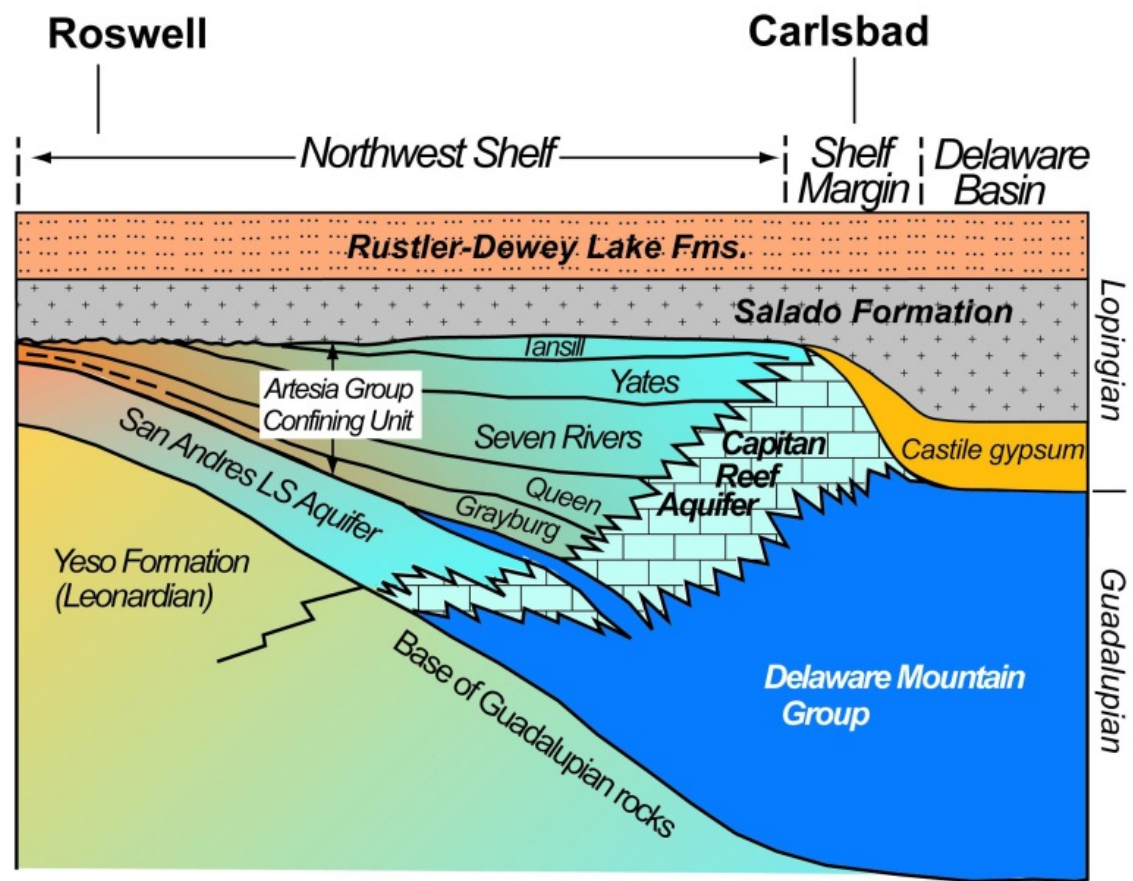

Figure 3. Stratigraphic profile showing facies relationships of Permian strata in the lower Pecos Valley.
Figure 2. Stratigraphy of the lower Pecos region, southeastern New Mexico.

\begin{tabular}{|c|c|c|c|c|}
\hline Era & Period & Epoch & $\begin{array}{l}\text { Northwest } \\
\text { Shelf }\end{array}$ & $\begin{array}{c}\text { Delaware } \\
\text { Basin }\end{array}$ \\
\hline \multirow[b]{4}{*}{$\mathcal{O}$} & \multirow{2}{*}{ Quatemary } & \begin{tabular}{|l|} 
Holocene \\
\end{tabular} & \multicolumn{2}{|c|}{ Pecos Valley alluvial fill } \\
\hline & & Pleistocene & \multicolumn{2}{|c|}{ Gatuna Formation } \\
\hline & \multirow{2}{*}{ Tertiary } & Neogene & \multicolumn{2}{|c|}{ Ogallala Formation } \\
\hline & & Paleogene & \multicolumn{2}{|c|}{ Sierra Blanca volcanics } \\
\hline \multirow{3}{*}{$\begin{array}{l}.00 \\
\frac{0}{0} \\
\frac{8}{2} \\
\sum\end{array}$} & Cretaceous & & & \\
\hline & Jurassic & & & \\
\hline & Triassic & & \multicolumn{2}{|c|}{ Santa Rosa Fm./Dockum Grp. } \\
\hline \multirow{11}{*}{\multicolumn{2}{|c|}{$\begin{array}{l}. \\
\text { N } \\
\text { O } \\
\frac{\Phi}{N} \\
\end{array}$}} & \multirow{3}{*}{$\begin{array}{l}\text { Lopingian } \\
\text { (Ochoan) }\end{array}$} & Rustler Fm. & Rustler Fm. \\
\hline & & & Salado Fm. & Salado Fm. \\
\hline & & & & Castile Fm. \\
\hline & & & \multirow{4}{*}{\multicolumn{2}{|c|}{ 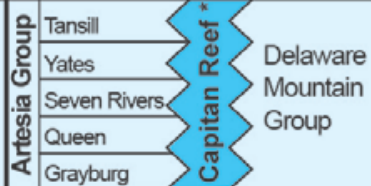 }} \\
\hline & & & & \\
\hline & & Guadalupian & & \\
\hline & & & & \\
\hline & & & \multirow{2}{*}{$\begin{array}{l}\text { San Andres } \\
\text { Formation }\end{array}$} & \multirow{3}{*}{$\begin{array}{l}\text { Bone Spring } \\
\text { Formation }\end{array}$} \\
\hline & & & & \\
\hline & & Leonardian & Yeso \Victorio Peak & \\
\hline & & Wolfcampian & Abo Formation & Hueco Group \\
\hline
\end{tabular}

"lower portion of reef section includes the Goat Seep Reef.

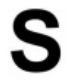


Text is based in part on road logs in Land and Love (2006). Distances are given in miles for consistency with United States odometers.

Vehicles assemble at NCKRI headquarters, 400-1 Cascades Ave., Carlsbad, NM. Proceed to intersection of Cascades Ave. and Park Dr. Zero odometers and turn left onto Park Dr.

0.3 miles: Potash mines locomotive on left; Lake Carlsbad, an impounded section of the Pecos River, on right. Continue north through traffic circle on Riverside Dr.

0.6 miles: Bear left and continue on Riverside Dr.

1.2 miles: Crossing Canal St., bridge to right crosses Pecos River. Continue straight on Riverside Drive, one of the more prosperous neighborhoods in Carlsbad. Homes on the right side of the street have back yards facing the Pecos River.

2.4 miles: Turn left onto Landsun Drive.

2.6 miles: Turn right onto Westridge Road.

\section{0 miles: Stop 1: Carlsbad Spring to right}

Carlsbad spring is one of several springs that discharge into this reach of the Pecos River. Carlsbad spring used to discharge over 7,500 liters/min ( $2000 \mathrm{gal} / \mathrm{min})$, but its flow has been substantially reduced over the years due to pumping from the Capitan Reef aquifer, the principal source of drinking water for the City of Carlsbad. Additional discharge from the spring is derived from leakage from Lake Avalon and the Carlsbad Irrigation District's South Canal, and from irrigation return flow (Cox, 1967).

Carlsbad flume is visible at 12:00, 200 $\mathrm{m}$ upstream from the spring. This large large concrete aqueduct crosses the Pecos and transports water of the Pecos River from Lakes Brantley and Avalon through the CID South Canal (thus, according to Ripley's Believe It or Not, "the river that crosses itself"). This concrete structure was built in 1903 to replace the original wooden flume that was destroyed by floods.

Return to vehicles and continue west on Westridge Rd, passing under flume.

3.2 miles: Stop sign. Turn left onto Callaway Dr.

3.4 miles: Traffic light. Turn right onto US 285. 
4.1 miles: Roadcut to left is an exposure of the shallow marine, outer shelf facies of the Tansill Formation on the northeast flank of Tracy Dome, dipping $10^{\circ}$ east toward the Pecos River. Dolomites of the grapestone-grainstone facies belt indicate deposition in the subtidal environment of a backreef lagoon.

Pecos River to right. Between Brantley Dam and Carlsbad Springs the Pecos River is a losing stream, in the process recharging near-backreef units of the Capitan Reef aquifer (Cox, 1967).

8.7 miles: NM 524 to left leads to Happy Valley. Continue straight on US 285. The hill on the left is a ridge surrounding a circular depression $1.5 \mathrm{~km}$ in diameter, interpreted by Motts (1962) as a young solution-collapse feature. Tansill dolomites on the flanks dip steeply toward the center of this crater-like structure, which is floored by gypsum of the Yates and Tansill Formations. Non-tectonic folds caused by subsurface dissolution and subsidence are widespread in this portion of the Pecos Valley. A well drilled to a depth of $336 \mathrm{~m}$ in the center of the depression bottomed in Seven Rivers dolomites (Kelley, 1971b).

9.9 miles: The feature superficially resembling a cinder cone on the skyline at 9:00 is Round Mountain, the largest of the so-called Three Twins, residual knolls formed in evaporites and redbeds of the Yates Formation and capped by more resistant Tansill dolomite. Such residual hills and ridges are common features in the carbonate-to-evaporite transitional facies belt of the Artesia Group.

10.0 miles: Roadcuts over the next mile expose interbedded gypsum, dolomite and redbeds of the Yates Formation, representing the carbonate-to-evaporite and redbed facies change within the Yates. Note small folds in the roadcuts, part of an arcuate fold belt called the Waterhole anticlinorium (Kelley, 1971a) that wraps around the west and north sides of the Carlsbad area.

12.1 miles: Cross Rocky Arroyo, a dry tributary of the Pecos River. Ridge at 10:00 is the Seven Rivers Hills, a southeast dipping cuesta of the Seven Rivers Formation.

12.9 miles: Turn right onto CR 30/Capitan Reef Road to Brantley Lake State Park. Brantley Dam to left. Driving over partially cemented terrace gravels of the Pecos River.

15.2 miles: Spillway of Brantley Dam at 9:00. Well-developed Holocene coppice dunes on both sides of road. Prominent bluffs on opposite bank of Pecos River at 1:00 are formed in Quaternary cemented terrace gravels, rotated as much as $40^{\circ}$ due to solution-subsidence in underlying evaporites, redbeds and dolomites of Yates transitional facies. 
15.4 miles: Cross Pecos River on bridge south of Brantley Dam.

17.5 miles: Road to left leads to Brantley Lake State Park and Visitors Center. Continue straight on CR 30.

17.7 miles: Cuesta to right is formed in redbeds and gypsum capped by dolomite of the Yates Formation.

18.7 miles: Cross railroad tracks. Yates gypsum exposed in railroad bed on both sides of road. McMillan Escarpment at 10:00. Dolomitic facies of Yates is exposed in railroad cuts 800 m SE.

19.2 miles: T-junction with Lake Road (CR 34). Turn left onto Lake Road.

19.5 miles: Stop sign at intersection with Netherlin Road. Continue straight.

20.1 miles: Seven Rivers dolomite capping cuesta at 3:00.

20.2 miles: McMillan Dam at 12:00. Brantley Lake at 9:30. Seven Rivers Hills on horizon (Seven Rivers dolomite capping redbeds and gypsum).

\section{3 miles: Stop 2: McMillan Dam and old Lake McMillan Lake Bed.}

Park on shoulder. Breached dam straight ahead. Note man-made dike along east margin of lake, at base of McMillan Escarpment (Figure 4). The following discussion is based largely on Cox (1967), who investigated geohydrologic conditions beneath McMillan Dam and downstream as far as Carlsbad Springs.

Lake McMillan is located within the evaporite facies belt of the Seven Rivers Formation. The lake was an artificial impoundment that formerly stored water for the Carlsbad Irrigation District. McMillan Dam was constructed in 1893, and the reservoir almost immediately began experiencing leakage problems through sinkholes formed in the lake bed, particularly along the eastern margin of the lake. Water flowed through karst conduits in the Seven Rivers gypsum and returned to the Pecos River through discharge from Major Johnson Springs, $5.6 \mathrm{~km}$ downstream at the present site of Brantley Reservoir. East and southeast of the facies change, the less soluble dolomite facies of the Seven Rivers retards any significant formation of solution channels. In 1908-09 a dike was constructed along the southeast shore of the lake, near the base of the McMillan Escarpment, in an attempt to isolate the areas of worst sinkhole formation. The dike was extended in 1953-54 along most of the eastern shore to prevent water from reaching exposed sinkholes during periods of high lake level. Occasionally breaks would occur in the dikes causing lake water to inundate the sinkholes. At these times whirlpools were reported in the lake, indicating that sediment cover over sinkholes in the lake bed had been disturbed. High 
rates of leakage would occur for short periods of time until the dikes were repaired and sediment cover on the floor of the lake restored.

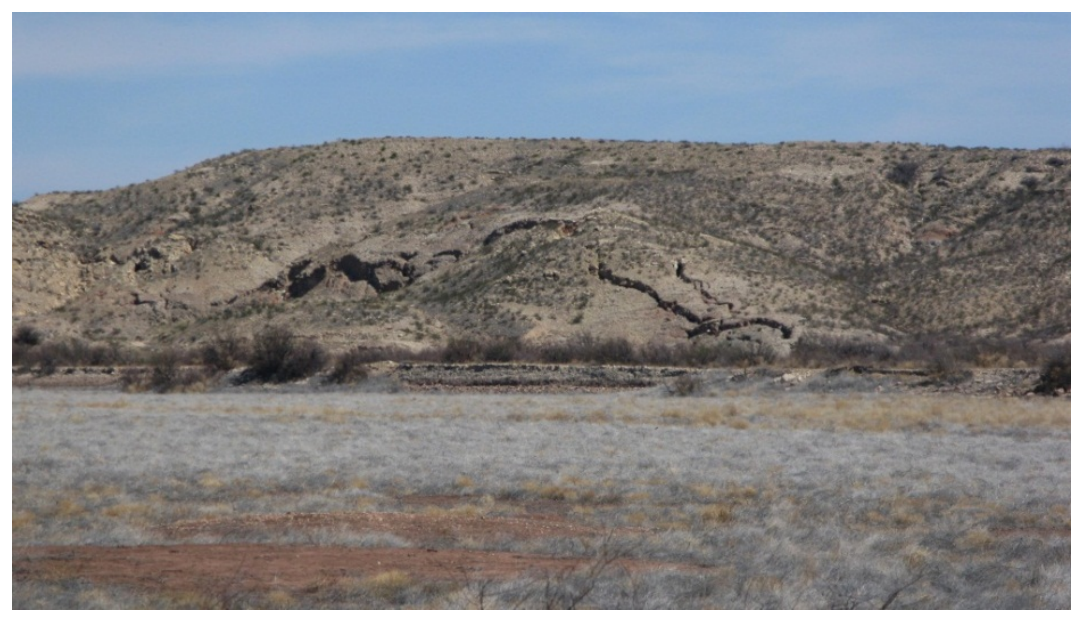

Figure 4. Mass wasting processes indicated by gypsum fissures formed in the face of the McMillan Escarpment. Note man-made dike at base of escarpment.

Storage capacity of Lake McMillan steadily decreased after the dam was constructed because of deposition of suspended sediment, particularly during flood events, and by the early 1940's less than half of its original storage capacity remained. The possibility of dredging was considered but soon discarded when it was realized that removal of the accumulated sediment would considerably increase leakage through karst fissures in the gypsum bedrock underlying the lake. Fortunately, loss of storage capacity decreased by the mid-40's because a stand of salt cedar, an invasive species, became established in bottom lands upstream from Lake McMillan, acting as a baffle for much of the suspended sediment carried by the Pecos River.

Consideration for construction of a new dam began as early as 1905. The U.S. Bureau of Reclamation began construction of Brantley Dam in 1984, and in 1991 McMillan Dam was breached and Lake McMillan allowed to drain into Brantley Lake. Based on recommendations by Cox (1967), the new reservoir is located mostly within the dolomitic facies belt of the Seven Rivers Formation.

Features to note near the old damsite include small-scale non-tectonic folds, expressed as undulations in the Seven Rivers dolomite, almost certainly the result of subsurface dissolution of evaporites. Larger-scale folds exposed in the walls of the Pecos River channel on the other side of the dam probably have a similar origin.

Return to vehicles and proceed to Stop 3. Zero odometer, turn around and proceed southeast on Lake Road.

0.8 miles: Intersection with Netherlin Road (CR236). Turn left. High clearance vehicles only from this point on. Other vehicles park on shoulder. 
1.4 miles: Slow down, turn left on two-track just before cattle guard. All remaining vehicles should have high clearance from here to stop 3 . Follow fence line.

1.7 miles: Turn left away from fence line. Watch for deep ruts in two-track.

2.3 miles: Two track reaches ridge crest. Lake bed of old Lake McMillan below. Northeast end of Brantley Dam at 7:00.

2.4 miles: Small sinkhole to right. Vehicles should be careful of footing.

\section{5 miles: Stop 3: Crest of McMillan Escarpment.}

The McMillan Escarpment is a cuesta formed in gypsum and redbeds of the Seven Rivers Formation, capped by more resistant Seven Rivers dolomites. The carbonate-to-evaporite and redbeds facies change can be readily observed in a vertical sense during a partial descent down the face of the escarpment. Also present are large gypsum fissures and slump blocks, indicating continued mass wasting and evolution of the eastern margin of the lower Pecos Valley by undercutting of the gypsum escarpment (Figure 5). Small gypsum caves and sinkholes occur at the base of the cliff. These karst features began causing serious leakage shortly after construction of the reservoir. Attempts to isolate the worst areas of sinkhole formation by construction of a dike along the eastern shore of the lake were only partially successful.

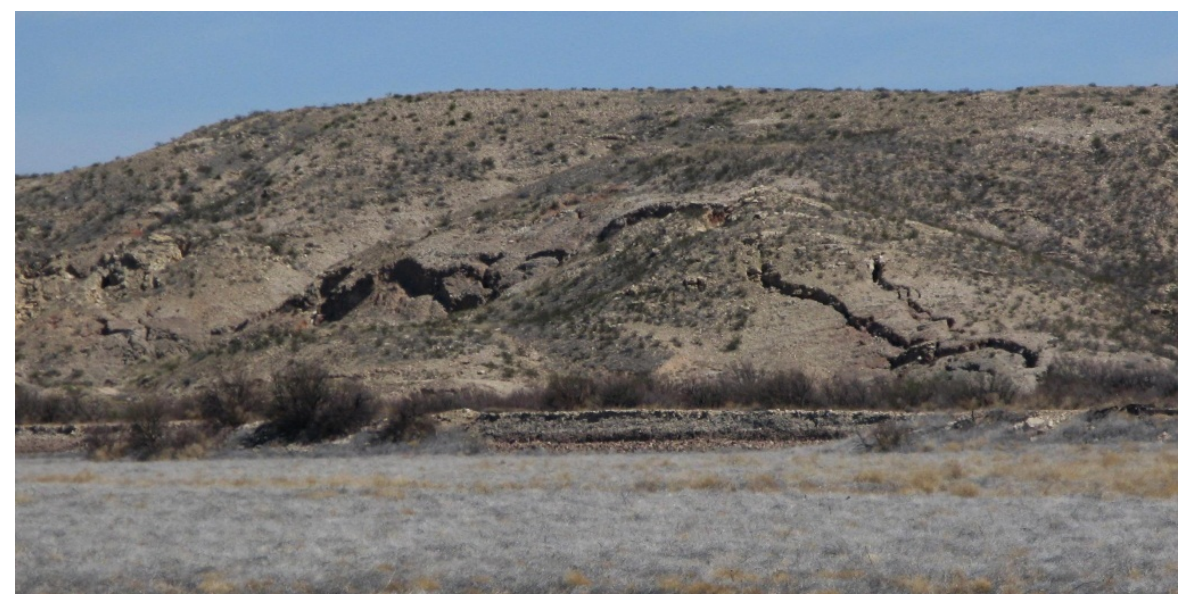

Figure 5. Mass-wasting processes indicated by large gypsum fissures formed in face of McMillan Escarpment.

Watch your footing on unstable slopes. After stop, return to Netherlin Road.

Zero odometers and turn right onto Netherlin Road.

0.5 miles: Junction of Netherlin and Lake Roads. Turn left onto Lake Road. 
0.8 miles: Junction with CR 30. Turn right and return to US 285.

7.1 miles: Junction of CR 30 with US 285. CR 30 is known as the Capitan Reef Road on the east side of the highway. The road continues across the highway toward the village of Queen in the high Guadalupes and is known as the Queen Highway. The Queen Highway is one of the earliest roads built by the Civilian Conservation Corps (CCC) in New Mexico. It connects US 285 with the Queen, El Paso Gap, and Dog Canyon areas of the western Guadalupe Mountains.

Prepare to turn right onto Highway 285. Re-zero odometers as you turn onto highway.

0.0: Turn right and proceed north on US 285.

0.3 miles: mile post (MP), MP 46.

1.0 miles: Seven Rivers Hills at 10:00. Brantley Dam at 3:00.

2.7 miles: Yates dolomite at top of roadcut on left probably overlies siltstone and gypsum covered by dolomite riprap.

3.0 miles: Brantley Lake road and boat ramp to right.

3.8 miles: Crest of Seven Rivers Hills. Brecciated redbeds and gypsum of the Seven Rivers evaporite facies are exposed in roadcuts to left and right. The McMillan Escarpment can be seen as a low cuesta east of the Pecos River at roughly 3:00. The north-south-trending Seven Rivers gypsum and dolomite outcrop belt, which forms the McMillan Escarpment, swings southwest at this point and crosses the Pecos River, due to a northeast-trending, southeast-dipping monocline. The same outcrop belt forms the cuesta of the Seven Rivers Hills, which are capped by more resistant dolomites of the Azotea Tongue of the Seven Rivers Formation (Kelley, 1971b). The Seven Rivers Hills are (somewhat arbitrarily) regarded as the southern boundary of the Roswell Artesian Basin.

3.9 miles: Descending into alluvial lowlands formed by a confluence of the Seven Rivers tributaries of the Pecos River. For the past several million years, the Pecos has been migrating progressively eastward due to uplift of the Sacramento Mountains to the west combined with dissolution of gypsum bedrock to the east. Floodplain deposits of the Pecos River form a shallow water-table aquifer in the Roswell Artesian Basin.

5.3 miles: MP 51. About $1 \mathrm{~km}$ to the west the New Mexico Interstate Stream Commission has drilled several augmentation wells to pump water from the deep Artesian Aquifer and pipe it directly into the Pecos River. These augmentation wells form part of a consensus plan between 
the Carlsbad Irrigation District (CID) and the Pecos Valley Artesian Conservancy District (PVACD) to help meet our interstate compact obligation to share water resources in the Pecos with the state of Texas.

5.9 miles: Crossing South Seven Rivers Arroyo. Pecan orchard to right. Pecans are an important cash crop in the largely agricultural economy of the Artesian Basin.

6.7 miles: Gravels capped with soil in roadcuts are Seven Rivers terrace deposits.

9.6 miles: MP 55. Junction with CR 31 to Lakewood to right. Residents of Lakewood were evacuated due to flooding during extreme monsoonal rains last fall, 2013. Several sinkholes formed in the aftermath of the flooding, one damaging a small structure in the Lakewood RV park. Continue straight.

10.4 miles: Crossing North Seven Rivers Arroyo. Route continues north on broad, east-sloping plain.

12.2 miles: Partially-cemented Quaternary gravel terrace deposits in roadcut to right.

12.6 miles: MP 58. Crossing Fourmile Draw.

14.1 miles: BP pipeline crosses under road. In 2003 several shallow fissures were discovered by a BP aerial survey in the vicinity of the pipeline (Figure 6). The fissures are probably associated with subsurface dissolution and subsidence in the Seven Rivers gypsum, which underlies the alluvial valley fill in this area. Depth of some of the fissures exceeds $1 \mathrm{~m}$ (Figure 7). 


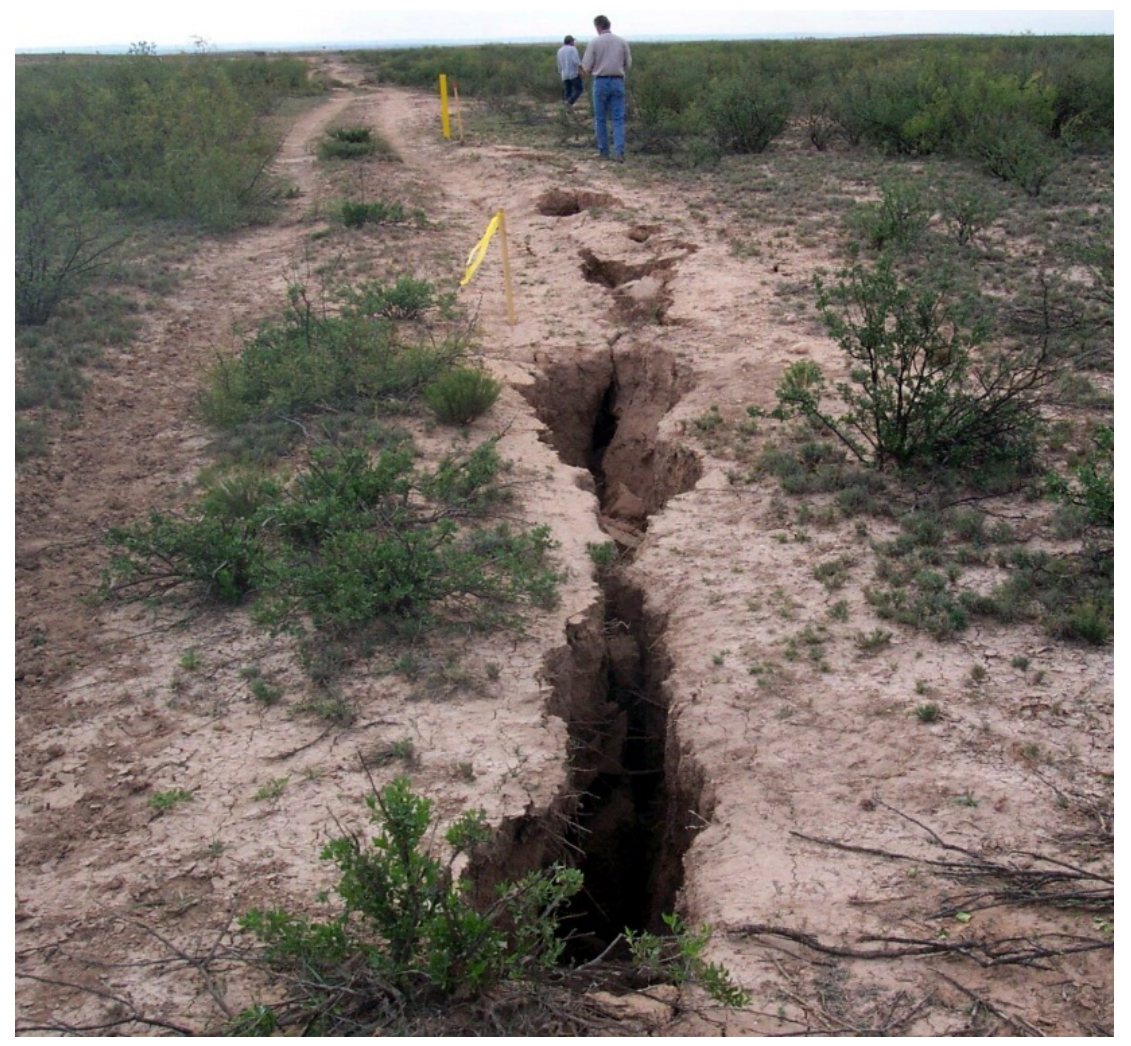

Figure 6. Fissure crossing pipeline access road south of Artesia, developed in alluvium overlying Seven Rivers evaporites.

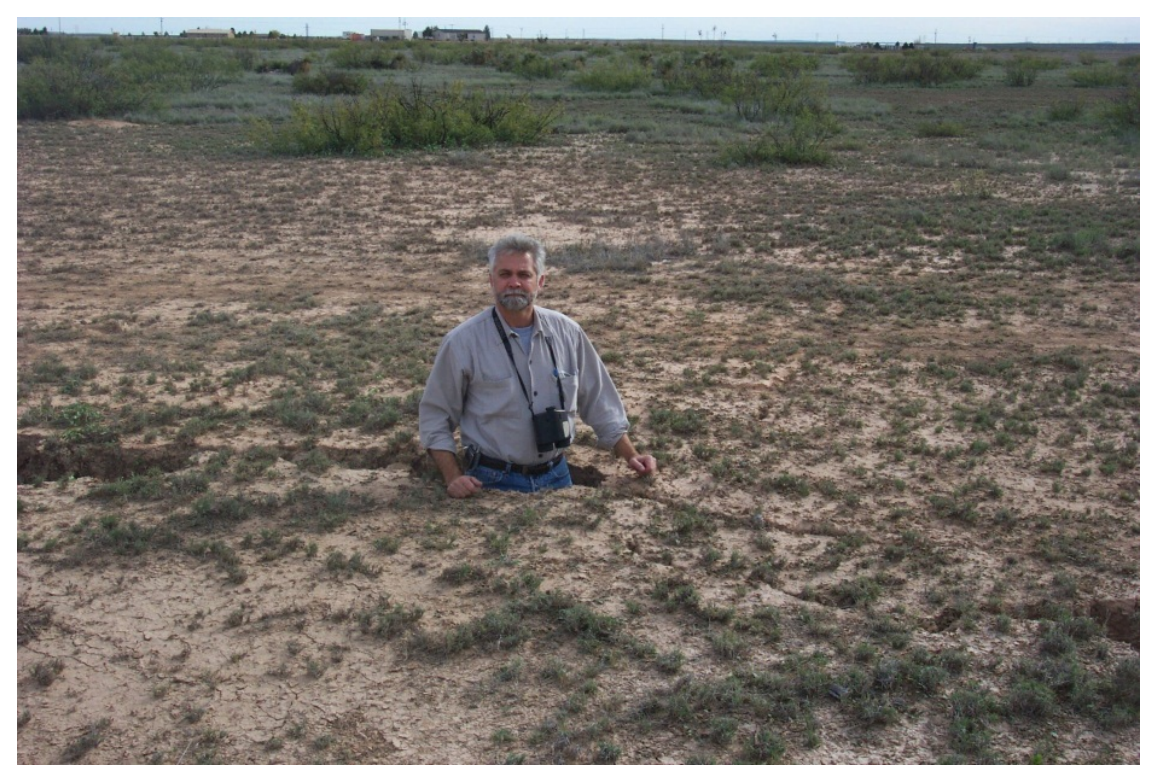

Figure 7. Close-up of earth fissure near pipeline south of Artesia. Consultant for scale. (consultant is 2 m long). 
14.4 miles: For the next several miles the route crosses a relatively nondescript terrain composed of pediment gravels, caliche soil and alluvial deposits of the ancestral Pecos River. The principal features to notice are the dense concentration of pump jacks and other oil and gas infrastructure on both sides of the highway. The first oil discovery in southeastern New Mexico was made in this area in 1924. The field trip route passes through a portion of the giant Empire Abo Field, which produces oil and gas from Permian strata of the Abo reef complex, Yates and Grayburg Formations of the Artesia Group, the San Andres limestone, Wolfcamp carbonates, as well as upper Pennsylvanian carbonates and lower Pennsylvanian clastic reservoirs in the Morrow and Atoka Formations. These multiple pay zones overlie the Artesia-Vacuum Arch, an east-west trending structural nose that extends to the east for $120 \mathrm{~km}$ into Lea Co., New Mexico (Kelley, 1971a). The Arch is almost completely covered by post-Permian beds; its principal surface manifestation is the high concentration of oil wells. Since $1960>200$ million barrels of oil have been produced from the Empire Abo field (Christiansen, 1989).

16.1 miles: The Slipper Gentlemen's club on the right, one of only two adult entertainment facilities in the lower Pecos Valley.

17.2 miles: Crossing the Rio Peñasco. The Peñasco is a perennial stream in the Sacramento Mountains to the west, but becomes a losing stream when it flows across the Pecos Slope west of Artesia, in the process recharging the underlying San Andres Artesian Aquifer.

18.2 miles: Junction with CR 65 to left. Continue straight. Sprinkler irrigation systems become increasingly common from this point north, as we drive farther into the Artesian Basin. Note the repeating image of three transformers on a utility pole and a mound of earth, indicating the presence of a nearby water well and pump and a pond for surface storage.

19.8 miles: Atoka Grocery on left. The village of Atoka grew along the ATSF railroad and is host to the Eddy County Arena. Note pecan orchards along both sides of the road.

21.8 miles: MP 67. Historic marker, showing the route of Castaño de Sosa’s 1590-91 expedition up the Pecos River.

22.0 miles: Halliburton service company yard to right.

22.5 miles: Entering southern Artesia. The town acquired its name in 1903 because of the abundant resources of artesian groundwater that were discovered in the area around the turn of the $20^{\text {th }}$ century, making the region an agricultural oasis. Principal crops include alfalfa, sorghum, chiles, and pecans. In recent years dairy farming has become increasingly important to the agricultural economy of the lower Pecos Valley. 
Artesia lies near the southern end of the Roswell Artesian Basin, from which groundwater is withdrawn from the karstic San Andres limestone aquifer to support irrigated agriculture. The Seven Rivers Formation in its redbed-evaporite facies serves as a leaky confining unit for the San Andres aquifer. Although water levels in the Artesian aquifer have declined substantially since development began in the early 1900s, some wells northwest of Artesia still display strong artesian flow.

24.1 miles: Main Street Artesia, and junction with Highway 82. Continue straight and proceed north through town. Navajo Refinery to right. In addition to irrigated agriculture, Artesia is also a local center for oil and gas activity. Yates Petroleum corporate headquarters is located 3 blocks to the west. The Wellhead Brewpub, owned by one of the Yates family and one of only two brewpubs in the lower Pecos Valley, is across the street from Yates' offices.

24.4 miles: Crossing Eagle Draw, an east-flowing tributary of the Pecos River.

26.6 miles: Artesia adult video store to left. Bear right onto Highway 2 and continue north.

29.8 miles: MP 3. Low hills at 2:30 on east side of valley are formed in redbeds of Seven Rivers Formation.

32.1 miles: Bridge over Cottonwood Creek. This drainage is controlled by large levees on both sides of the channel for several $\mathrm{km}$.

32.8 miles: Chavez County line. At this point the route crosses the NNE-trending subsurface KM fault. The KM fault parallels the Pecos Buckles, a series of surface faults that extend across the Pecos Slope to the west. Like the Buckles, the KM fault is thought to combine right-lateral motion with normal vertical displacement, and may be of Laramide age (Kelley, 1971a). The hydraulic gradient in the Artesian Aquifer increases abruptly just west of the KM fault, indicating that it acts as a partial barrier to down-gradient groundwater flow. Water levels are several tens of meters deeper in the Artesian Aquifer on the southeast side of the fault.

\section{0 miles: Crossing Walnut Creek.}

35.1 miles: Entering outskirts of Lake Arthur, one of several small agricultural communities of the lower Pecos Valley between Roswell and Artesia. In 1977, a Lake Arthur resident discovered an image of Jesus Christ on a flour tortilla she was preparing for her husband. By 1979, the Shrine of the Holy Tortilla had been visited by over 35,000 of the faithful. Images of Christ on a tortilla were later reported in Phoenix, AZ and Hidalgo, TX, but the Lake Arthur holy tortilla may be the first documented sighting in recent history. 
36.1 miles: Lake Arthur cemetery to left. Sierra Blanca, composed of igneous intrusives and volcanics, on western horizon at 9:00. Capitan Mountains batholith at 10:00.

39.6 miles: El Gomez bar on left.

43.4 miles: Entering Hagerman, home of the Hagerman Bobcats. Unlike most communities in the Artesian Basin, Hagerman farmers derive most of their irrigation water from the Hagerman Canal west of town, rather than from the Artesian Aquifer, and secondarily from wells in the shallow alluvial aquifer. The Hagerman canal originally transported water south from the Rio Hondo east of Roswell. Because of intensive pumping from the Artesian Aquifer, all of the tributaries of the Pecos River, including the Rio Hondo, have been dry for many decades, except during brief flood events. For this reason, most of the "surface water" in the Hagerman canal is actually groundwater pumped into the canal from wells. Pumping from the shallow aquifer has resulted in a significant cone of depression in agricultural areas west of town.

45.0 miles: Historic bridge to right over the Rio Felix, another of the now dry tributaries of the Pecos River.

45.3 miles: Red bluffs east of Pecos River at 2:30 are formed in Seven Rivers redbeds and gypsum.

49.7 miles: Entering village of Dexter, home of the Dexter Demons. As the Pecos Slope descends to the east toward the river, the potentiometric surface approaches ground level. Water levels in wells near the river are only a meter or two deep, and many wells near Dexter still display strong artesian flow during winter months when irrigation is minimal.

50.3 miles: Turn right and cross railroad tracks onto First St./Shawnee Road East (NM 190).

51.1 miles: Lake Van, an artificially flooded sinkhole, is visible between houses to the right, south of Shawnee Road. Lake Van is one of at least nine lakes or seasonal lakes here.

51.6 miles: Dexter Fish Hatchery entrance to right. The Dexter National Fish Hatchery and Technology Center was established in 1931 to meet the demand for warm water game fish; its main focus was to supply local waterways with sport fish via rearing at the Center. After the Endangered Species Act was established in 1973 the hatchery mission was transformed from a facility that raised fish for recreational purposes to a facility that would house and protect endangered fish species. The Center is the only federal facility in the nation dedicated to holding, culturing and studying fishes facing extinction. 
51.8 miles: Route descends low terrace of Pecos River. Agricultural activity quickly diminishes east of Dexter because of deteriorating water quality east of the freshwater-saltwater interface in the Artesian Aquifer. Groundwater near the Pecos River has a TDS content in some areas as high as $7,000 \mathrm{mg} / \mathrm{l}$.

52.4 miles: Sharp bend to left onto Wichita Road.

52.7 miles: Zuber Lake Farm and artesian well to right. Rock-walled mound in front of house is an intermittently-flowing spring.

53.2 miles: Crossing Pecos River. Note banks 3 - $4 \mathrm{~m}$ high with natural levee sloping to the east. The banks are lined with Catclaw and Salt Cedar (Tamerisk), an invasive species. Water in this reach of the Pecos River is quite brackish, with TDS >2,000 ppm. Lakes along the river are a combination of oxbows and sinkholes.

53.5 miles: Sharp left turn to north.

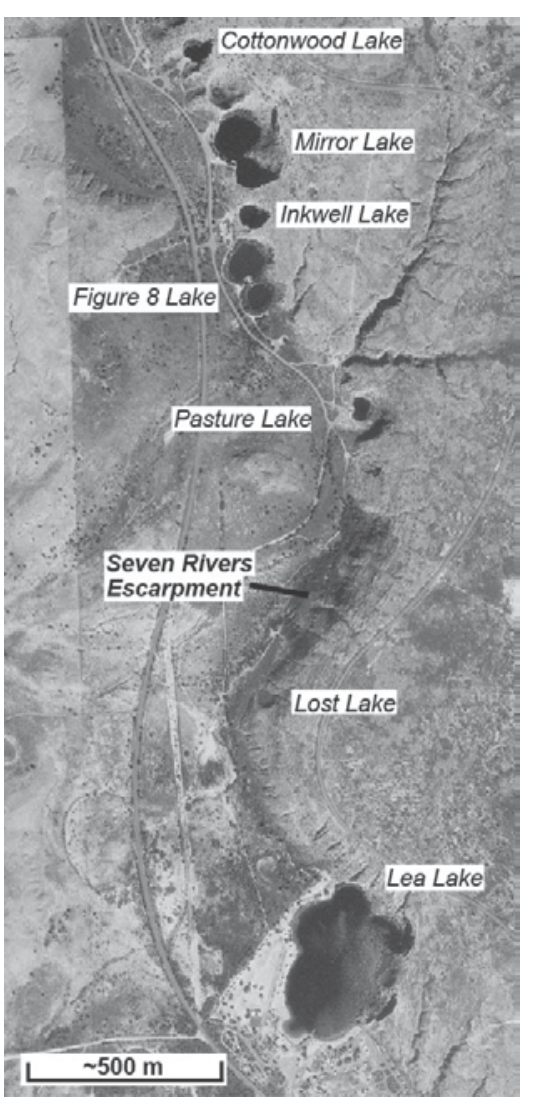

54.9 miles: Bear right, staying on paved road, and begin ascending Seven Rivers escarpment. For the next five miles the route crosses extensive exposures of Seven Rivers gypsum and mudstone.

56.4 miles: Sacramento Mountains on western horizon; Sierra Blanca on skyline at 8:30. Capitan Mountains batholith at 9:30. City of Roswell across valley at 9:00. Reddish-brown ridge on far horizon to east is part of the outcrop belt of Triassic Santa Rosa Sandstone.

60.9 miles: Road veers left and descends into valley. Dimmitt Lake to right, a large sinkhole lake on private land. Lea Lake, the largest of the cenotes of Bottomless Lakes State Park, at 11:30.

61.3 miles: Stop sign. Turn left toward Bottomless Lakes State Park.

Figure 8. Digital orthophoto image of Bottomless Lakes State Park, showing flooded cenotes. All lakes visible in this image are formed in gypsum and redbeds within the Seven Rivers Escarpment, a geologic setting similar to that observed at Lake McMillan. 
61.5 miles: Cross Lea Lake overflow canal; turn right into Lea Lake parking lot.

61.6 miles: Stop 4: Lea Lake sinkhole, Bottomless Lakes State Park. Bus parks in parking lot. Field trip participants assemble by lake shore.

Lea Lake sinkhole is the only lake in Bottomless Lakes State Park where swimming is permitted. Because of the clarity of the water, the lake is popular with local scuba divers. Bottomless Lakes is New Mexico's first state park, established in 1933. The sinkhole lakes are formed in gypsum and mudstone of the Seven Rivers Formation, and are some of the larger and more impressive examples of the many sinkholes and other karst features that line the lower Pecos Valley (Figure 8).

The Bottomless Lakes sinkholes may more properly be described as cenotes because of their deep, steep-walled morphology, similar to the cenotes formed in limestone bedrock on the Yucatan Peninsula in Mexico (Caran, 1988). The cenotes of the lower Pecos Valley are unusual in that they occur in a semi-arid setting, where annual evaporation rates may exceed mean annual precipitation by a factor of 7 or more. The lower Pecos region is also unique in that it is one of the few areas in the world where sinkholes are actively forming in a region of groundwater discharge rather than recharge (Salvati and Sasowsky, 2002).

These sinkholes, and the many others that occur in the lower Pecos Valley, are the product of subsurface dissolution of gypsum by upward leakage of groundwater from the karstic San Andres limestone, which comprises most of the artesian aquifer in the Roswell Artesian Basin (Figure 9) (Martinez et al., 1998). The lakes are fed by submerged springs discharging from the artesian aquifer, and thus represent the down gradient end of the regional hydrologic system in the Artesian Basin. Discharge from the springs has caused subsurface dissolution of evaporites within the Seven Rivers Formation, localized subsidence, and upward propagation of collapse 


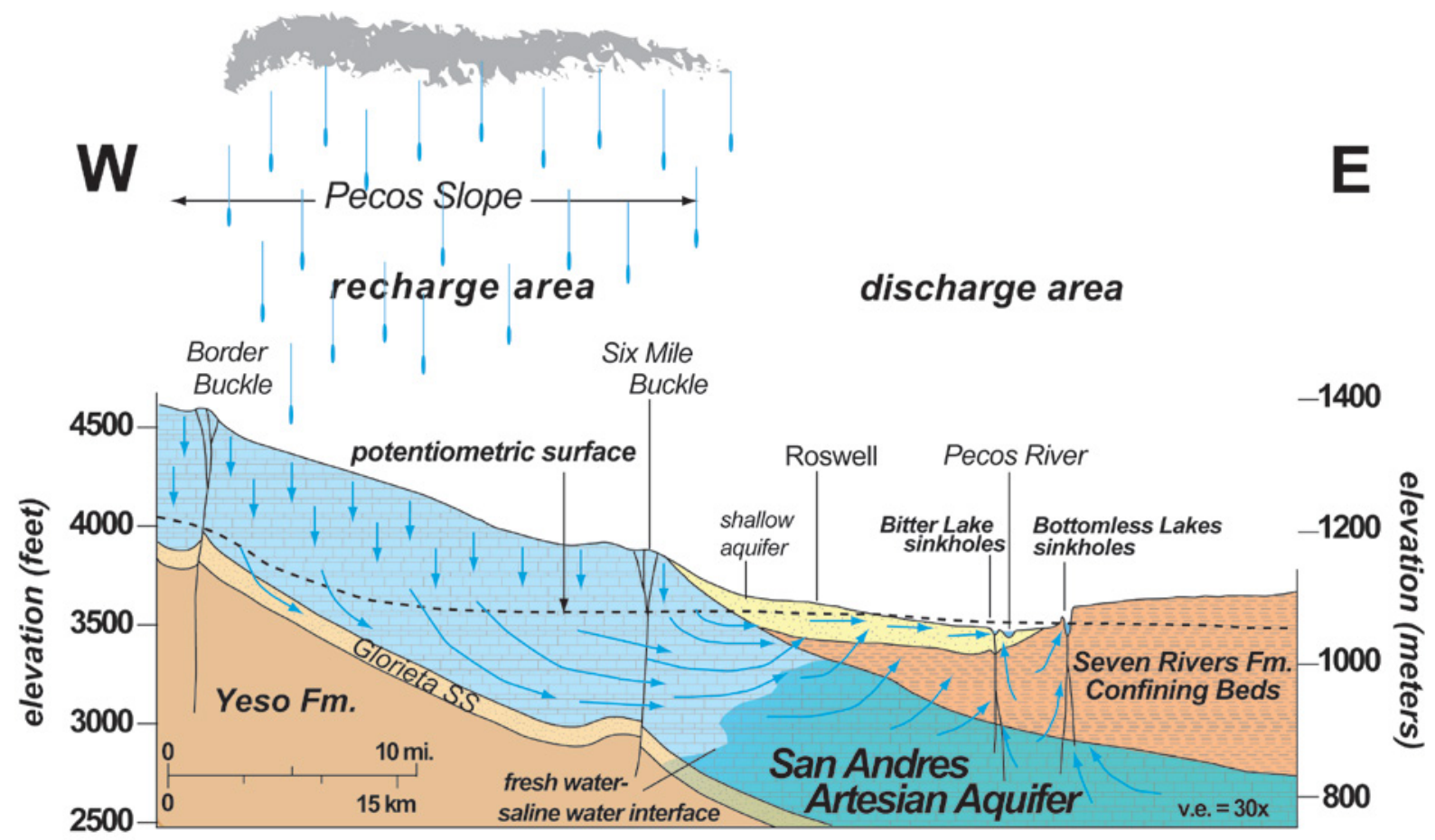

Figure 9. West-east hydrostratigraphic section of the artesian aquifer system in the vicinity of Bottomless Lakes State Park. Recharge occurs by direct infiltration from precipitation, and by runoff from intermittent losing streams that flow eastward across the Pecos Slope west of Roswell. Groundwater flows east and south, down gradient from the recharge area, then upward through leaky confining beds into the alluvial aquifer, and ultimately into the Pecos River.

chimneys, which ultimately formed the cenotes (Land, 2003). Spring sapping at the base of the Seven Rivers escarpment has also resulted in oversteepening of the eastern walls of the sinks, causing occasional rockslides and other mass-wasting events, an indication of the fundamental role that gypsum karst processes have played in shaping the morphology of the lower Pecos Valley.

The gentle $\left(\sim 1^{\circ}\right)$ eastward regional dip of the area is locally reversed along the escarpment, where strata of the Seven Rivers Formation dip abruptly southwest by as much as $40^{\circ}$. This local dip reversal, best viewed in the walls of Mirror Lake, is probably the result of subsurface dissolution of gypsum in the vicinity of the sinkholes and consequent slumping of overlying beds (James Quinlan ${ }^{1}$, unpublished report, 1967).

Bottomless Lakes occurs on the saline side of the fresh water/saline water transition in the Roswell Artesian Basin (Figure 9), thus water in all the lakes is brackish, with Total Dissolved Solids (TDS) content ranging from $\sim 6000$ to 38,000 mg/L. In spite of the high mineral content, some of the lakes are periodically stocked with fish.

${ }^{1}$ The late James F. Quinlan very precisely summarized the geology and hydrology of Bottomless Lakes State Park in the text and graphics of an unpublished Christmas card he circulated among friends in 1967. 
The Roswell Artesian Basin is one of the most intensively farmed areas in New Mexico, deriving virtually all of its irrigation water from groundwater stored in the artesian and alluvial aquifers. Since the inception of irrigated agriculture in the Artesian Basin more than a century ago, most of the discharge from the artesian aquifer has been from wells, although substantial natural discharge still occurs through fractures and solution channels in the overlying confining beds (Welder, 1983). Groundwater from the artesian aquifer discharges into the many springs and sinkhole lakes that line the Pecos River, and is manifest in the development of extensive wetlands above and below Roswell. These wetlands are visible along the river immediately west of Bottomless Lakes, and to the north at Bitter Lake National Wildlife Refuge (Land and Newton, 2008).

Figure 10. Rockslide in Seven Rivers Escarpment, eastern shore of Lea Lake cenote.

In the early history of settlement in this area, most of the cenotes at Bottomless Lakes overflowed into wetlands along the eastern shore of the Pecos River, but the progressive decline in hydraulic head in the

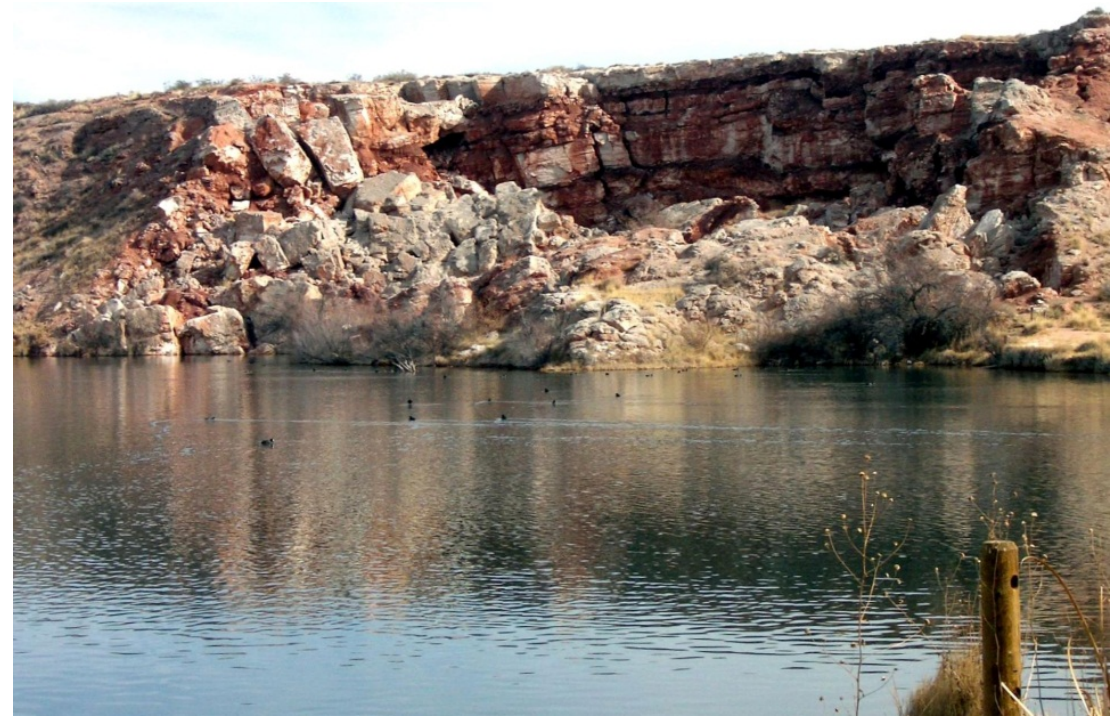
artesian aquifer (up to $70 \mathrm{~m}$ in some areas) caused lake levels to fall, so that now only Lea Lake overflows. In 1975, a catastrophic rockslide occurred on the steep eastern wall of Lea Lake (Figure 10), and the resulting lake surge caused significant damage to a pavilion on the opposite shore. No measurements of lake discharge are available prior to 1976 (probably because there was no discharge overflow before that date). However, the rockslide appears to have been associated with an increase in spring discharge and the opening of new spring outlets in the lake bed, as indicated by a significant post-rockslide increase in flow from the lake and the flooding of adjacent grazing lands with several million gallons per day of saline and alkaline water. A culvert was installed to convey the increased flow into wetlands west of the park, but the lake continued to flood an adjacent parking lot and camping area during the winter. In 2002, the park completed construction of a more efficient drainage canal to capture all of the discharge, resulting in a substantial increase in the measured flow volume from the lake. As discharge continued to increase, a second drain was installed in 2005. On January 14, 2006, the New Mexico Interstate Stream Commission measured a combined discharge of 576.2 liters/s (20.35 cfs) from both drains.

The increased flow from Lea Lake, amounting to roughly 18 million $\mathrm{m}^{3} / \mathrm{yr}(\sim 14,600$ acre-ft/yr), has caused an expansion of wetlands to the west, which are now hydraulically connected to the Pecos River, and a net gain in streamflow downstream from the park, an interesting phenomenon in a semi-arid region that is currently experiencing an extended drought. 
Field trip participants return to vehicles and proceed to Stop 6. Zero odometer at visitor pay station, exit parking lot and turn left onto loop road.

0.4 miles: Begin ascent of Seven Rivers Escarpment. Dimmit Lake to right.

1.0 miles: Turn left into scenic overlook parking lot.

\section{Stop 5: Lea Lake scenic overlook.}

We are standing on the Seven Rivers Escarpment, in a geologic setting very similar to that at the McMillan Escarpment farther south. As at Stop 2, large fissures are formed in the Seven Rivers gypsum along the upper edge of the escarpment, and large rockslides can be observed where they have fallen into the lake, showing the continued morphologic evolution of the lake margin by mass wasting. The principal difference between this location and Lake McMillan is the presence of active discharge of artesian groundwater at the base of the Seven Rivers Escarpment, enhancing mass wasting processes. At least half a dozen springs discharge from the lakebed in $\sim 8 \mathrm{~m}$ water depth at the base of the escarpment, suggesting that spring sapping may have played a role in initiating the 1975 rockslide.

Field trip participants return to vehicles and proceed to Stop 6. Exit parking lot and turn left onto loop road.

3.7 miles: Lazy Lagoon at base of escarpment to left. During winter months, when water levels are high due to low levels of irrigation from the Artesian Aquifer, Lazy Lagoon appears to be a single body of water. It is in fact three sinkholes formed in an abandoned channel of the Pecos River, the southernmost of which is over $25 \mathrm{~m}$ deep. The Lazy Lagoon sinkholes contain the most saline water in the park, with TDS exceeding 37,000 mg/l, greater than the salinity of seawater.

3.9 miles: Bear left, and begin descent of Seven Rivers Escarpment. Over the next mile the route passes large gypsum slump blocks detached from the escarpment.

5.0 miles: Lazy Lagoon sinkholes to right.

5.9 miles: Dry sinkholes in escarpment to left.

6.2 miles: Turn left into Bottomless Lakes visitors center parking lot. 


\section{Stop 6: Cottonwood Lake cenote, Mirror Lake, and Bottomless Lakes visitors center.}

Cottonwood Lake is a small cenote containing water that in the past has been fresh enough to support fish, although too brackish for them to reproduce. Note rockslide on the far wall of the sink. The visitors center contains excellent exhibits, including air photo images and a 3-D model of all the sinkholes in the park.

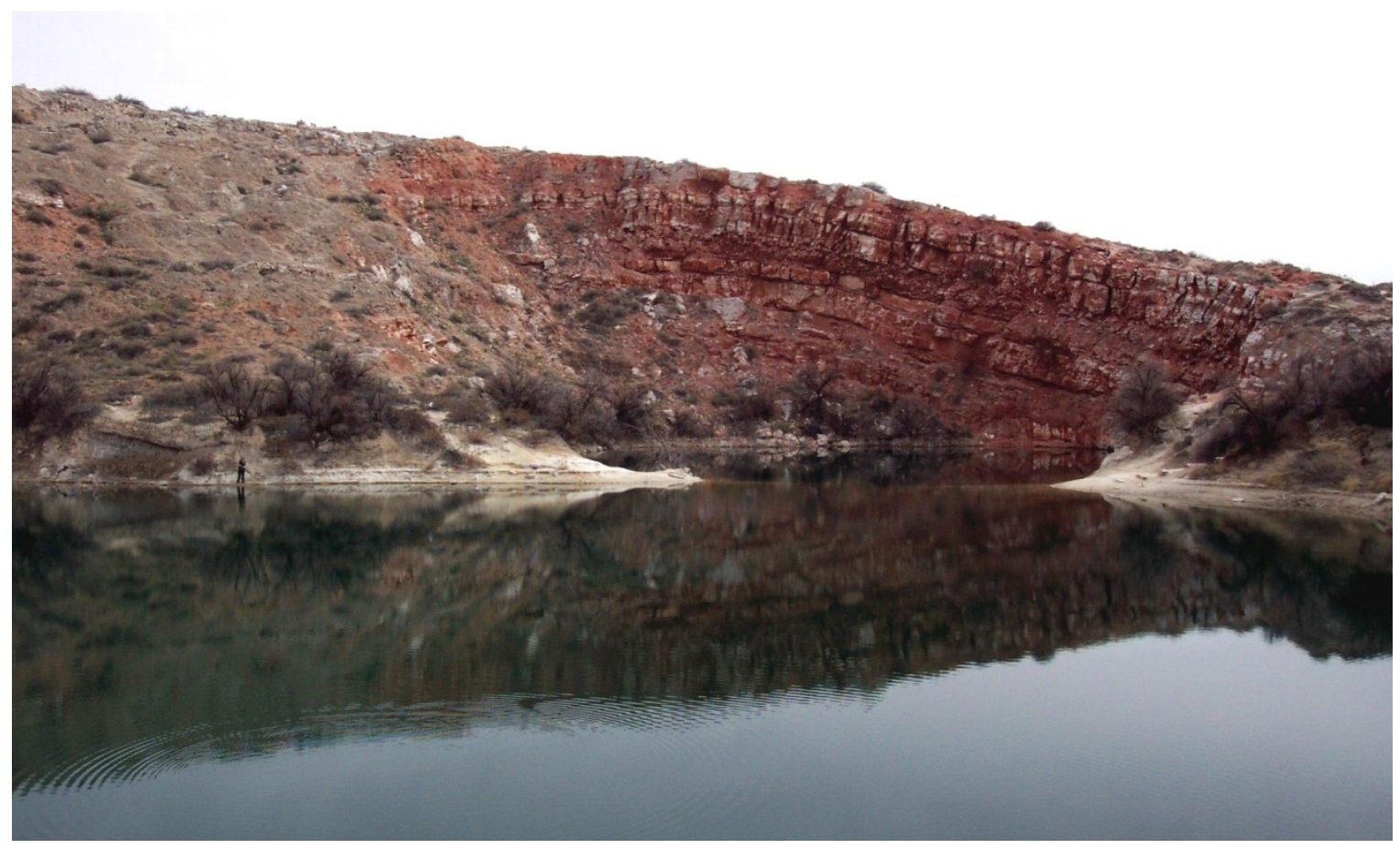

Figure 11. Mirror Lake, view to south.

A trail along the escarpment continues south for $\sim 300 \mathrm{~m}$, crossing a dry sinkhole and terminating at Mirror Lake, a compound lake consisting of two cenotes that have grown together (Figure 11, and cover photo). A climb to the top of the escarpment reveals large gypsum fissures and small tectonic caves formed in the upper margin of the sinkholes. Excellent examples of gypsum karren are exposed in bluffs along the north margin of Mirror lake. Note the pronounced west dip exposed in the walls of the Mirror Lake cenote. Regional dip is about $1^{\circ}$ to the east. This local dip reversal is probably the result of subsurface dissolution of gypsum along the escarpment.

Field trip participants return to vehicles. Zero odometer, exit visitors center parking lot, and turn left onto loop road.

2.0 miles: Pass Lea Lake entrance and turn right onto Wichita Road, following same route back to Carlsbad. 
10.8 miles: Turn right onto Shawnee Road.

13.0 miles: In Dexter, turn left onto Highway 2 and continue south toward Hagerman.

36.4 miles: Turn left onto Highway 285, drive straight through Artesia.

58.9 miles: Begin crossing Seven Rivers Hills; Brantley Reservoir to left.

72.0 miles: Entering city of Carlsbad; Tracy Dome/C-Hill to right. US-285 becomes W. Pierce St.

74.6 miles: Bear right onto South Canal St.

75.1 miles: Turn left onto Church St.

75.6 miles: Turn right onto Park Dr. and return to NCKRI headquarters.

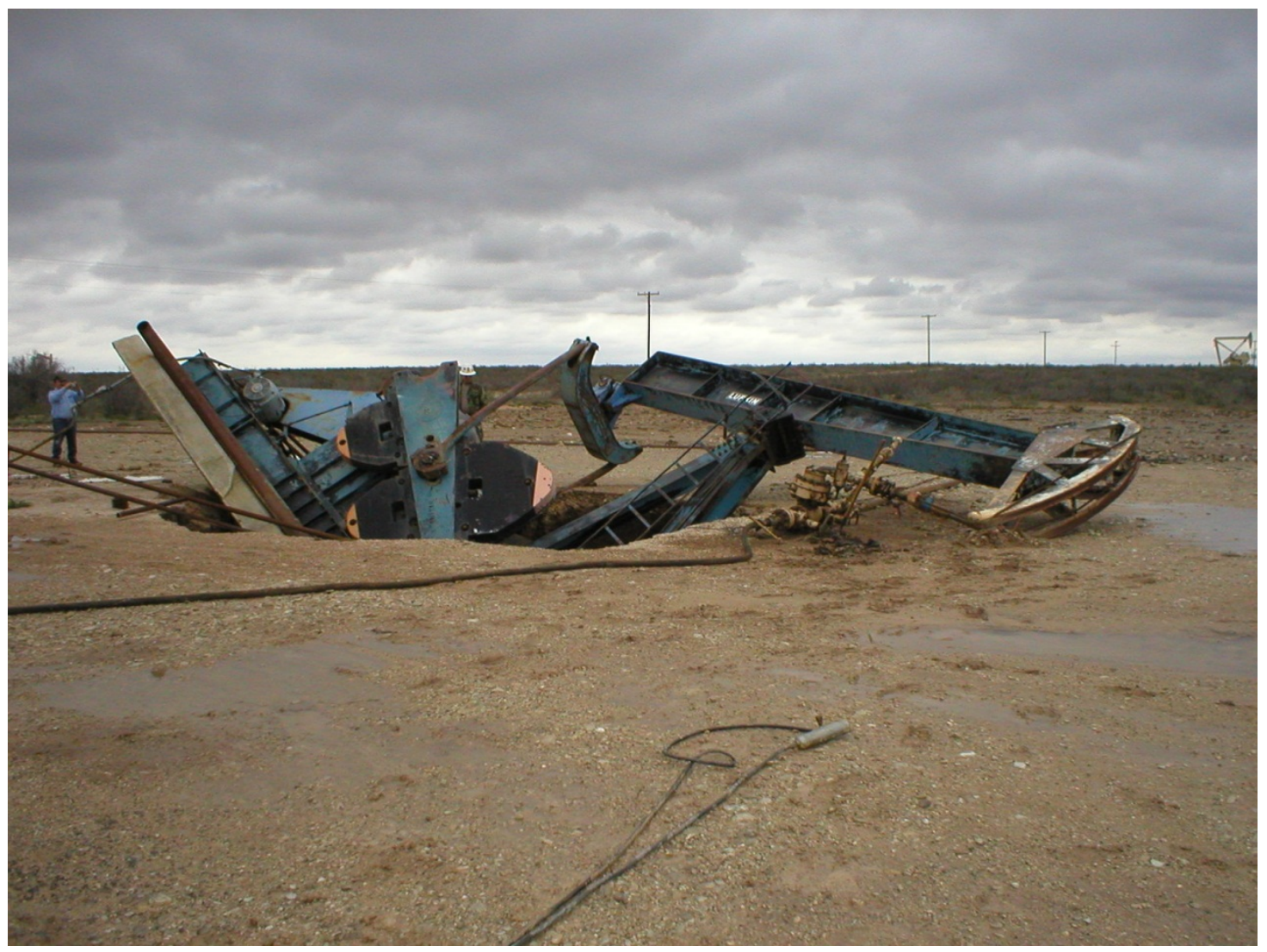

Figure 12. Pump jack in sinkhole, Dagger Draw oil field, Eddy Co., New Mexico. 


\section{REFERENCES}

Caran, S., 1988, Bottomless Lakes, New Mexico - A model for the origin and development of ground water lakes: Geological Society of America, Abstracts with Programs, v. 20, no. 2, p. 93.

Cheeseman, R.J., 1978, Geology and oil/potash resources of Delaware Basin, Eddy and Lea Counties, New Mexico, in Austin, G.S. (ed.), Geology and mineral deposits of Ochoan rocks in Delaware Basin and adjacent areas: New Mexico Bureau of Mines and Mineral Resources Circular 159, p. 7-14.

Christiansen P.W., 1989, The story of oil in New Mexico: New Mexico Bureau of Mines and Mineral Resources Scenic Trips to the Geologic Past, no. 14, 112 p.

Cox, E.R., 1967, Geology and hydrology between Lake McMillan and Carlsbad Springs, Eddy County, New Mexico: U.S. Geological Survey Water-Supply Paper 1828, 48 p.

Goodman, W.M., J.M. Schneider, J.D. Gnage, D.A. Henard, and L.L. Van Sambeek, 2009, Two-dimensional seismic evaluation of the I\&W brine cavern, Carlsbad, New Mexico: RESPEC Topical Report RSI-2083, http://www.emnrd.state.nm.us/OCD/documents/RSI2083.pdf.

Kelley, V.C., 1971a, Geology of the Pecos country, southeastern New Mexico: New Mexico Bureau of Mines and Mineral Resources, Memoir 24, 75 p.

Kelley, V.C., 1971b, Stratigraphy and structure of the Pecos country, southeastern New Mexico: West Texas Roswell Geological Societies Guidebook, Publication 71-58, 83 p.

Land, L., 2003, Evaporite karst and regional ground-water circulation in the lower Pecos Valley of southeastern New Mexico, in Johnson, K.S., and Neal, J.T., eds., Evaporite karst and engineering/environmental problems in the United States: Oklahoma Geological Survey Circular 109, p. 227-232.

Land L., 2012, Geophysical records of anthropogenic sinkhole formation in the Delaware Basin region, southeast New Mexico and west Texas, USA: Carbonates and Evaporites. (in press)

Land, L., and Aster, R., 2009, Seismic recordings of an anthropogenic sinkhole collapse, in Proceedings of the Symposium on the Application of Geophysics to Engineering and Environmental Problems: Environmental and Engineering Geophysical Society, 2009 Annual Meeting, Fort Worth, Texas, p. 511-519.

Land, L., and Love, D., 2006, Third day road log, in Land, L., Lueth, V., Raatz, B., Boston, P., and Love, D., eds., Caves and karst of southeastern New Mexico: New Mexico Geological Society, Guidebook 57, 344 p.

Land, L., and Newton, B.T., 2008, Seasonal and long-term variations in hydraulic head in a karstic aquifer: Roswell Artesian Basin, New Mexico: Journal of the American Water Resources Association, v. 44, p. 175-191.

Land L., and Veni, G., 2012, Electrical resistivity surveys of anthropogenic karst phenomena, southeastern New Mexico: New Mexico Geology 34 (4): 117-125.

Martinez, J.D., Johnson, K.S., and Neal, J.T., 1998, Sinkholes in evaporite rocks: American Scientist, v. 86, p. 3851.

McCraw, D.J., and Land, L., 2008, Preliminary geologic map of the Lake McMillan North 7.5-Minute quadrangle map, Eddy County, New Mexico: New Mexico Bureau of Geology and Mineral Resources, Open-File Geologic Map-167, 1:24,000.

Motts, W.S., 1962, Geology of the West Carlsbad quadrangle, New Mexico: U.S. Geological Survey Geologic Quadrangle Map GQ-167.

Salvati, R., and Sasowsky, I.D., 2002, Development of collapse sinkholes in areas of groundwater discharge: Journal of Hydrology, v. 264, p. 1-11.

Welder, G.E., 1983, Geohydrologic framework of the Roswell ground-water basin, Chaves and Eddy Counties, New Mexico: New Mexico State Engineer Technical Report 42, 28 p.

Woods, D.A., 2011, Z-Scan review former I\&W facility, Carlsbad, New Mexico: DMT Technologies Final Report for EMNRD/Oil Conservation Division, http://www.emnrd.state.nm.us/OCD/documents/IWMagnetotelluricReport.pdf. 
